UNIVERSIDADE ESTADUAL PAULISTA

EVERTON JOSÉ GOLDONI ESTEVAM

(RES)SIGNIFICANDO A EDUCAÇÃO ESTATÍSTICA NO ENSINO FUNDAMENTAL: ANÁLISE DE UMA SEQUÊNCIA DIDÁTICA APOIADA NAS TECNOLOGIAS DE INFORMAÇÃO E COMUNICAÇÃO 
EVERTON JOSÉ GOLDONI ESTEVAM

\title{
(RES)SIGNIFICANDO A EDUCAÇÃO ESTATÍSTICA NO ENSINO FUNDAMENTAL: ANÁLISE DE UMA SEQUÊNCIA DIDÁTICA APOIADA NAS TECNOLOGIAS DE INFORMAÇÃO E COMUNICAÇÃO
}

\begin{abstract}
Dissertação de Mestrado apresentada ao Programa de Pós-Graduação em Educação da Faculdade de Ciências e Tecnologia, UNESP/Campus de Presidente Prudente, como exigência parcial para obtenção do título de Mestre em Educação.

Orientador: Prof. ${ }^{a}$ Dr. ${ }^{a}$ Monica Fürkotter
\end{abstract}

Presidente Prudente

2010 
Autorizo a reprodução e divulgação total ou parcial deste trabalho, por qualquer meio convencional ou eletrônico, para fins exclusivos de estudo e pesquisa, desde que citada a fonte.

Estevam, Everton José Goldoni.

E84r (Res)Significando a Educação Estatística no Ensino Fundamental: análise de uma sequência didática apoiada nas Tecnologias de Informação e Comunicação / Everton José Goldoni Estevam. - Presidente Prudente : [s.n], 2010 $\mathrm{xvi}, 211 \mathrm{f}$. : il.

Dissertação (mestrado) - Universidade Estadual Paulista, Faculdade de Ciências e Tecnologia

Orientador: Monica Fürkotter

Banca: Celi Espasandin Lopes, Maria Raquel Miotto Morelatti Inclui bibliografia

1. Educação Estatística. 2. Ensino Fundamental. 3. TIC. 4. SuperLogo 3.0. 5. Sequência Didática. I. Autor. II. Universidade Estadual Paulista. Faculdade de Ciências e Tecnologia. III. Título.

CDD(18.ed.) 370 


\section{unesp \\ Campus de Presidente Prudente}

\section{BANCA EXAMINADORA}

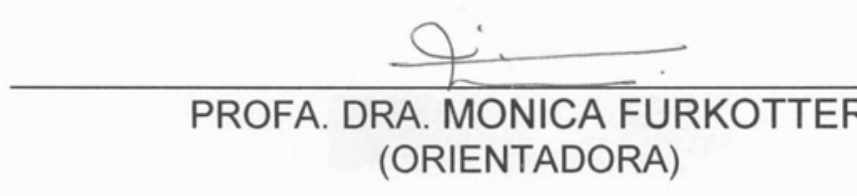

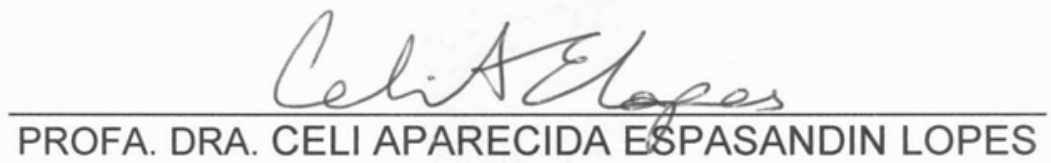
(UNICSUL)
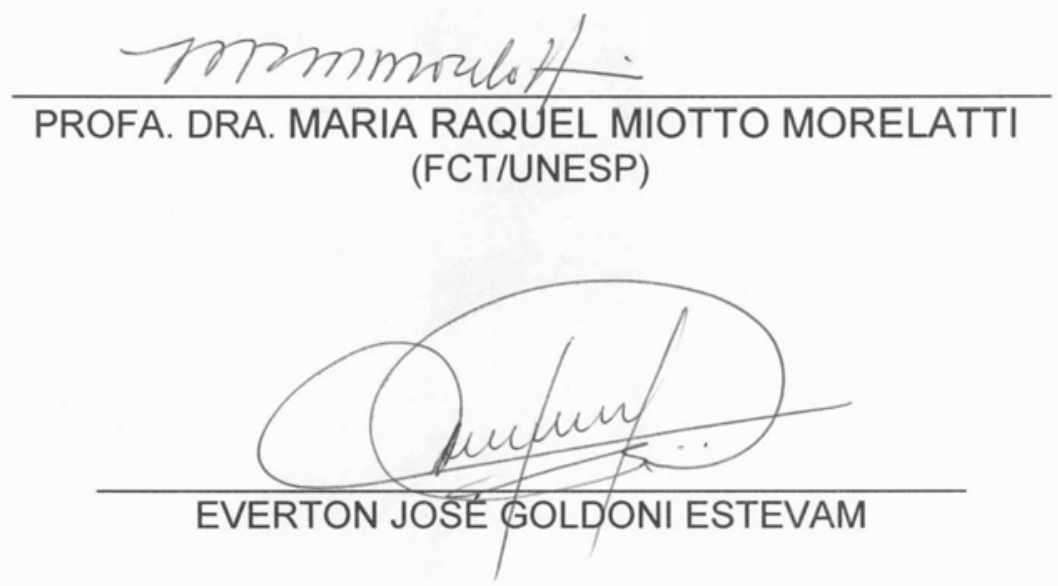

PRESIDENTE PRUDENTE (SP), 09 DE JUNHO DE 2010.

RESULTADO: Amovado 
Dedico este trabalho àqueles que fizeram o que hoje sou:

meu pai, José Estevam Neto, hombridade, companheirismo e paciência;

minha mãe, Mercedes Goldoni Estevam, persistência, força de vontade e superação;

minha irmã, Eliane Aparecida Estevam de Oliveira, que me ensinou que não importa de onde viemos, importa aonde queremos chegar;

meu irmão, Emerson José Goldoni Estevam, com quem aprendi que as diferenças só nos enriquecem, porque complementam o que nos falta. 
Para a construção deste trabalho, muitos foram aqueles que (cada um a seu modo) contribuíram para a superação de adversidades, de dúvidas e de inquietações. Eles estimularam-me a fortalecer princípios e objetivos, a manter-me perseverante na busca de respostas e esclarecimentos para a vida pessoal e profissional.

A minha querida orientadora, Prof. ${ }^{a}$ Dr. ${ }^{a}$ Monica Fürkotter, por ter aceitado o desafio de explorar uma área tão complexa, por não ter medido esforços para me auxiliar nos constantes momentos de dúvidas e angústias. Reconheço que este trabalho deve muito a sua persistência, paciência, competência profissional e retidão moral.

A Prof..${ }^{a}$ Dr. ${ }^{a}$ Celi Espasandin Lopes, pela disponibilidade generosa para propor adequações pertinentes e singulares durante todo o processo de construção e desenvolvimento da pesquisa, particularmente durante o Exame de Qualificação.

A Prof. ${ }^{a}$ Dr. ${ }^{a}$ Maria Raquel Miotto Morelatti, motivadora sensível e competente da área de Educação Matemática, que abriu meu caminho para Pós-Graduação em Educação.

A minha família, pela paciência e pela generosidade, alicerçadas no amor incondicional.

Aos amigos e colegas do Programa de Pós-Graduação em Educação da Unesp de Presidente Prudente (SP), pelo prazer de compartilhar experiências e idéias.

Aos docentes do Programa de Pós-Graduação em Educação da Unesp de Presidente Prudente, particularmente, à Prof. ${ }^{a}$ Dr. ${ }^{a}$ Yoshie Ussami Ferrari Leite, à Prof. ${ }^{a}$ Dr. ${ }^{a}$ Cláudia Maria de Lima, à Prof. ${ }^{a}$ Dr. ${ }^{a}$ Leny Rodrigues Martins Teixeira, ao Prof. Dr. Cristiano Amaral Garboggini Di Giorgi e ao Prof. Dr. Alberto Albuquerque Gomes, pelos momentos de discussão e reflexão visando ao delineamento e fundamentação desta pesquisa.

À comunidade da Unesp de Dracena (SP), meu local de trabalho, particularmente à Coordenadoria Executiva do Campus, nas pessoas do Prof. Dr. Mário De Beni Arrigoni e Prof. Dr. Paulo Alexandre Monteiro de Figueiredo, por autorizar meu afastamento, durante o qual pude realizar as atividades de ensino e pesquisa, geradoras desta dissertação de Mestrado. 
Aos amigos e colaboradores da Unesp de Dracena, em particular, Renato, Rodrigo, Mariana, Renan, Fernando, Fábio, Mírian e Carol, que assumiram a responsabilidade da Seção e, assim, possibilitaram meu afastamento, garantindo o bom andamento das atividades.

Aos grandes amigos Piva, Rodrigo, Neto, Bel, Mariana, Vanessa, Márcio, Lucas, Alan, Roberto e Marcelo, pelos momentos de descontração e alegria.

Aos colegas do Grupo de Investigação Latino-Americano de Educação Estatística (GILEE) pelas constantes trocas de informação e experiência.

À Ana Carolina, amiga, amante, conselheira, incentivadora e companheira. Se amar é colocar o outro em primeiro lugar e não medir esforços para lhe proporcionar um sorriso, eu sei o quanto me ama. Agradeço-lhe a generosidade, o carinho e a paciência. Essa conquista é (em grande parte) sua, por tudo o que fez (e faz) por mim todos esses dias. Amo-a e admiro-a muito.

A Deus, pelo amor silencioso e sem medida. 
Feliz é aquele que transfere o que sabe e aprende o que ensina

(Cora Carolina) 


\section{RESUMO}

Este trabalho, desenvolvido no contexto da linha de pesquisa Práticas e Processos Formativos em Educação, do Programa de Pós-Graduação em Educação, teve por objetivo avaliar as contribuições de uma investigação exploratória de dados e das Tecnologias de Informação e Comunicação (TIC) para o processo de ensino e aprendizagem de conceitos estatísticos no Ensino Fundamental, particularmente no que concerne à atribuição de significado a informações apresentadas por meio de gráficos e tabelas. Assim, situa-se no bojo da Educação Estatística, área que tem sido objeto de estudo de inúmeras pesquisas nos últimos anos, na medida em que, diante do grande volume de informações presentes na sociedade contemporânea, emerge no contexto educacional (mas não apenas nele) a necessidade de se estruturar e discutir alternativas que viabilizem o tratamento adequado desses dados. A sequência didática baseada na investigação exploratória de dados visou a envolver os alunos num processo real de investigação estatística, abrangendo as três dimensões das intenções educativas: conceitual, por envolver conceitos estatísticos e matemáticos; procedimental, por pautar-se nos procedimentos relacionadas com a investigação; e atitudinal, por vislumbrar o desenvolvimento da capacidade crítica diante de dados e informações estatísticas presentes no dia-a-dia. Foram utilizados os softwares Microsoft Excel, para a organização dos dados e SuperLogo 3.0 para a construção dos gráficos. A pesquisa foi desenvolvida à luz da Engenharia Didática e dos pressupostos teóricos da Teoria das Situações Didáticas de Brousseau, da Teoria dos Registros de Representação Semiótica de Duval e das orientações do Guidelines for Assessment and Instruction in Statistics Education (GAISE) Report: a PréK-12 Curriculum Framework. A investigação envolveu 27 alunos de uma oitava série (nono ano) do Ensino Fundamental de uma escola estadual do interior do estado de São Paulo. Os resultados apontam a importância da problematização e do contexto para a compreensão dos conceitos e habilidades que permeiam todas as etapas de uma investigação estatística. $\mathrm{O}$ Microsoft Excel, apesar de não ser um software educacional, mostrou-se um facilitador para organização dos dados, em virtude de sua estrutura de planilha eletrônica. Já o SuperLogo 3.0 possibilitou que os alunos ressignificassem o processo de construção gráfica, à medida que favoreceu a mobilização de diversos conceitos e ideias matemáticos e estatísticos nas construções realizadas na linguagem de programação LOGO. Além disso, a construção de gráfico no SuperLogo 3.0 envolveu o raciocínio proporcional, compreensão de fundamental importância para a leitura e interpretação desse tipo de representação. Finalmente, pelas características da sequência desenvolvida, foi possível abordar o conceito de variabilidade, fator que diferencia substancialmente a Estatística da Matemática, para, a partir da compreensão da variabilidade entre indivíduos e entre grupos, proporcionar a construção fundamentada do princípio da amostragem aleatória.

Palavras-chave: Educação Estatística; Ensino Fundamental; TIC; SuperLogo 3.0; Sequência Didática. 


\begin{abstract}
The present study is inserted in Practices and Formative Process in Education search area and it is part of Post-Graduation Program in Education of Universidade Estadual Paulista UNESP. The aim of this study was to evaluate the contributions an exploratory data investigation and an investigation of Information and Communication Technology (ICT) would have to teaching-learning process of statistics concepts in Secondary School, especially concerning the meaning given to graphics and tables. Thus, this research is connected to Statistics Education that has been a wild explored area in which the great amount of data present in society and educational contexts can be organized. The didactic sequence based on data investigation aimed to involve students in a real process of statistics investigation including the three educative intuitions: conceptual, once statistic and mathematical concepts were involved; practical, because there were practice related to investigation; attitude, once it required a critical view of every day statistics situations. To do so, the following software was applied: Microsoft Excel for data organization and SuperLogo 3.0 for graphics construction. This study was developed according to Didactic Engineering and theoretical statements of Didactic Situations Theory by Brousseau, Semiotic Representation Register Theory by Duval and Guidelines for Assessment and Instruction in Statistics Education (GAISE) Report: a PréK-12 Curriculum Framework. The present study was carried out with 27 students from 8th grade Secondary School, between 14 and 15 years old. They were all from a public school in São Paulo state, Brazil. The results showed the importance of creating a problem-situation and a context in order to help the students to understand the concepts and abilities involved in statistics investigation steps. Microsoft Excel made it easier once it was possible to organize data. SuperLogo 3.0 provided the students the chance of re-meaning graphic constructions because the software provided the mobilization of mathematical and statistics concepts and ideas through LOGO programming language. Besides, this software provided proportional thinking, which is essential for reading and comprehension of such kind of representation. Finally, through the developed sequence it was possible to work with variability concept that distinguishes Statistics from Mathematics, moving from the comprehension of individuals and groups variability to the sample.
\end{abstract}

Key words: Statistics Education; Secondary School; ICT; SuperLogo 3.0; Didactic Sequence. 


\section{LISTA DE FIGURAS}

FIGURA 1: Estrutura do milieu

FIGURA 2: Resultados obtidos pela Escola A no Saresp 2005................................... 83

FIGURA 3: Princípios da GAISE que fundamentarão a sequência didática...................... 92

FIGURA 4: Estrutura da sequência didática................................................................... 93

FIGURA 5: Eixo do gráfico de barras com erro de proporcionalidade.............................. 136

FIGURA 6: Resultado de erro de comando................................................................. 137

FIGURA 7: Utilização de um eixo de 700 passos de tartaruga............................................ 138

FIGURA 8: Gráfico da $6^{\mathrm{a}}$ série rotulado/apagado com a palavra casa várias vezes............ 139

FIGURA 9: Gráfico da $8^{\mathrm{a}}$ série $\mathrm{X}$ rotulado sobre as barras com a tartaruga fora do centro

FIGURA 10: Erro decorrente dos comandos apresentados pelo G. 3 ............................... 141

FIGURA 11: Colunas rotuladas do lado de fora e em diagonal....................................... 141

FIGURA 12: Erro na construção do histograma............................................................. 144

FIGURA 13: Histograma do G. 6 a partir dos dados do $2^{\circ}$ ano do EM (a) errado e

(b) corrigido 144

FIGURA 14: Eixo do gráfico de colunas co erro na escola 168

FIGURA 15: Eixos dos gráficos de colunas com erro na proporção estabelecida entre os dados reais e os passos de tartaruga 168

FIGURA 16: Eixo correto do gráfico de colunas construído após as depurações 170

FIGURA 17: Erro do G.2 decorrente de "esquecimento" da proporção estabelecida........ 170

FIGURA 18: Barra construída corretamente de acordo com a proporção estabelecida....... 171 


\section{LISTA DE TABELAS}

TABELA 1: Organização dos dados da $8^{\mathrm{a}}$ série X para a Questão 5................................ 122

TABELA 2: Organização dos dados da $8^{\mathrm{a}}$ série X para a Questão 7................................. 123

TABELA 3: Organização dos dados da 8a série X para a Questão 6.................................. 124 


\section{LISTA DE QUADROS}

QUADRO 1: O quadro modelo da estrutura conceitual em Educação Estatística.............

QUADRO 2: Classificação dos diferentes registros mobilizados no funcionamento matemático (fazer matemático, atividade matemática)

QUADRO 3: Realização do Saresp.

QUADRO 4: Níveis de proficiência em Matemática na Prova Brasil para a $8^{\mathrm{a}}$ série do Ensino Fundamental

QUADRO 5: Identificação dos alunos da $8^{\mathrm{a}}$ série $\mathrm{X}$ da Escola $\mathrm{A}$, envolvidos na pesquisa

QUADRO 6: Esboço da proposta de organização dos dados da aluna

QUADRO 7: Estrutura da tabela para os dados referentes ao computador

120

QUADRO 8: Estrutura da tabela para os dados referentes ao computador acrescida das linhas e colunas totalizadoras.

QUADRO 9: Classificação das variáveis da investigação. 
ASA - American Statistical Association

DE - Diretoria de Ensino

EF - Ensino Fundamental

EM - Ensino Médio

ENEM - Exame Nacional do Ensino Médio

GAISE - Guidelines for Assessment and Instruction in Statistics Education

INAF - Índice de Alfabetismo Funcional

Inep - Instituto Nacional de Estudos e Pesquisas Educacionais Anísio Teixeira

MEC - Ministério da Educação

MSN - Microsoft Service Network

NCTM - National Council of Teachers of Mathematics

Nied - Núcleo de Informática Aplicada à Educação

PCN - Parâmetros Curriculares Nacionais

PCSP - Proposta Curricular do Estado de São Paulo

Saeb - Sistema de Avaliação da Educação Básica

SAI - Sala Ambiente de Informática

Saresp - Sistema de Avaliação de Rendimento Escolar do Estado de São Paulo

SEESP - Secretaria de Educação do Estado de São Paulo

SMS - Short Message Service

TIC - Tecnologias de Informação e Comunicação

Unesp - Universidade Estadual Paulista "Júlio de Mesquita Filho"

Unicamp - Universidade Estadual de Campinas

ZPD - Zona Proximal de Desenvolvimento 


\section{SUMÁRIO}

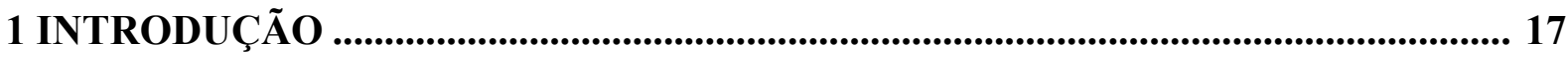

1.1 As ViVências que Originaram o Problema de Pesquisa ....................................... 17

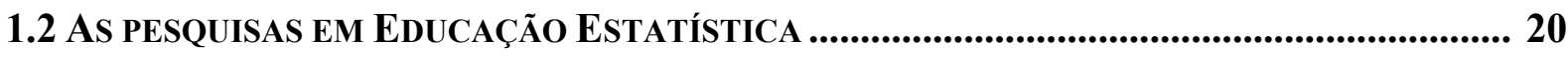

1.3 DELINEAMENTO DA(S) QUESTÃo(ÕES) E OBJETIVO(S) PARA A INVESTIGAÇÃO............... 23

1.4 A Engenharia didática como Metodologia de Pesquisa .................................... 24

1.5 CARACTERIZAÇÃo da UnidAde Escolar E do Grupo de Alunos InVESTIGAdos ... 26

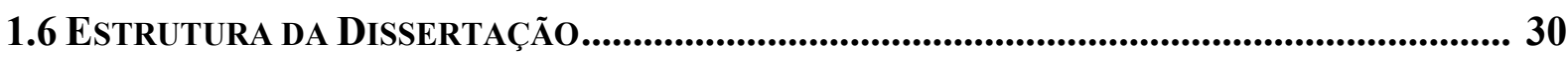

2 PRESSUPOSTOS TEÓRICOS PARA A PESQUISA ...................................................... 31

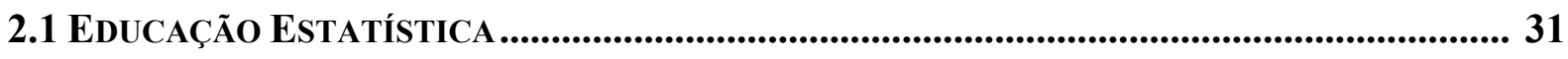

2.1.1 Educação Estatística no Ensino Fundamental ........................................................ 35

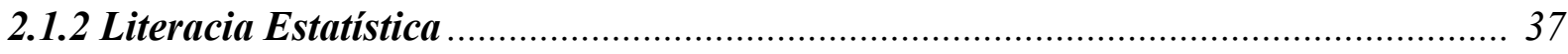

2.1.3 O Guidelines for Assessment and Instruction in Statistics Education (GAISE)

Report: a Pré-K-12 Curriculum Framework: fundamentos e princípios............................ 40

2.1.4 Construção, Leitura e Interpretação de Gráficos...................................................... 43

2.1.4.1 Gráficos: fundamentos para leitura e interpretação................................................ 45

2.1.4.2 Tabelas: estrutura, leitura e interpretação ................................................................ 46

2.2 A TEORIa de REgISTROS de REPRESENTAÇÃo SEMIÓtiCA........................................... 48

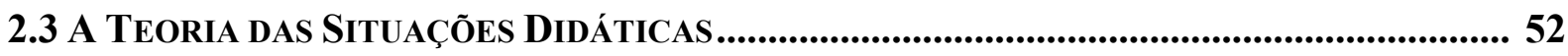

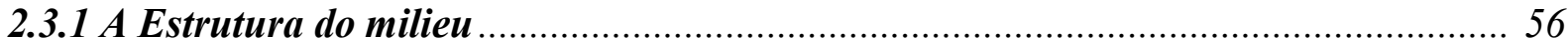

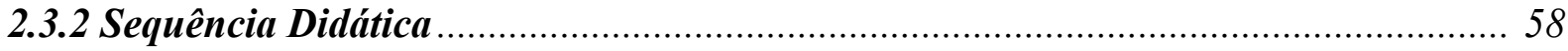

2.4 A TECNOLOGIA COMO FATOR (RES)SIGNIFICANTE NO ENSINO DE ESTATÍSTICA ........... 60

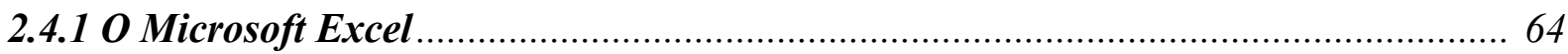

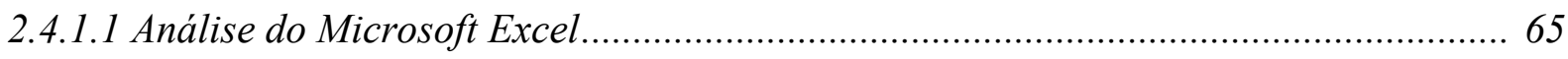

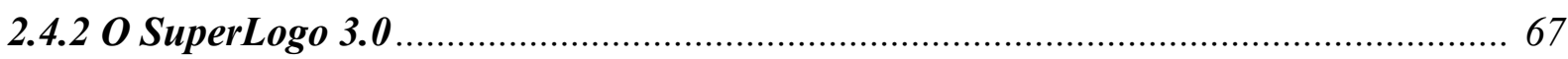

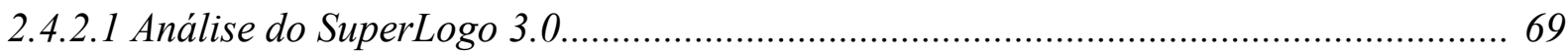

3 ANÁLISES PRELIMINARES: (RE)CONHECENDO O ESTADO ATUAL DO ENSINO E APRENDIZAGEM DE ESTATÍSTICA ................................................... 72

3.1 ParÂMetros CURRICUlares NACIONAIS ........................................................................ 72

3.2 O CuRrículo do Estado de São Paulo .................................................................. 75 
3.2.1 Os cadernos do Professor da PCSP para o Ensino Fundamental . 76

3.3 LIVRO DidÁtico. 78

3.4 Avaliações: Sistema de AvaliaÇão de Rendimento Escolar do EsTAdo de

São Paulo (SAResP) 81

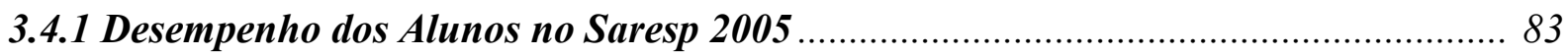

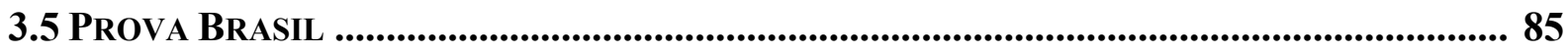

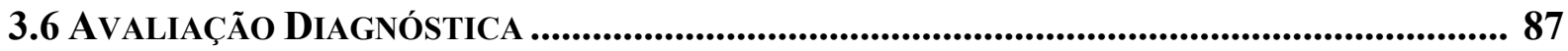

3.7 CONSIDERAÇõeS ACERCA DAS ANÁLISES PRELIMINARES........................................... 89

4 CONCEPÇÃO E ANÁLISE $A$ PRIORI DA SEQUÊNCIA DIDÁTICA........................ 91

4.1. Fundamento Conceitual Para A SEquênCIA: o GAISE ...................................... 91

4.2 ESTRUTURAÇÃo das SITUAÇÕES DidÁtiCas .............................................................. 93

4.2.1 Definição de um tema de interesse dos alunos ........................................................ 94

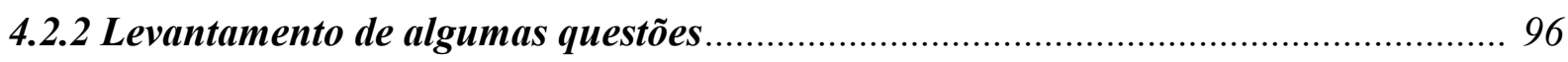

4.2.3 Definição de um instrumento para a coleta de dados ............................................ 97

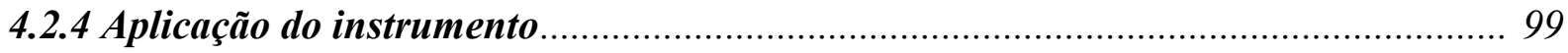

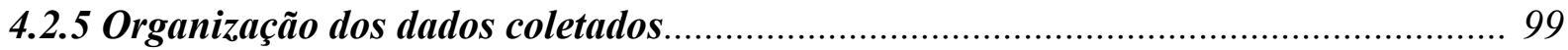

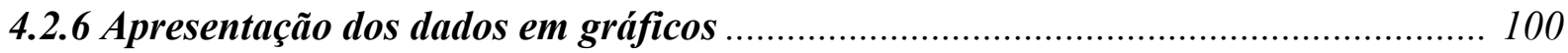

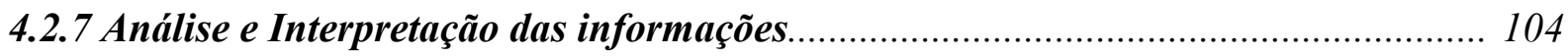

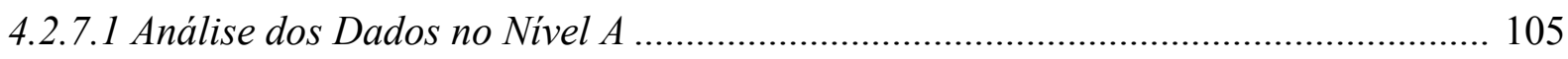

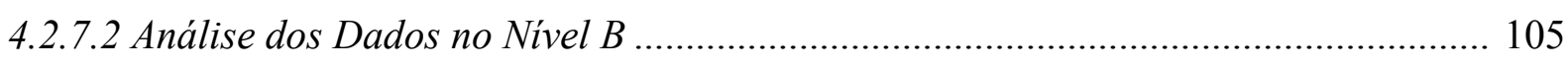

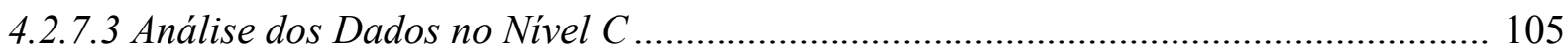

4.3 DisCuSSÃo dA SEQUÊNCIA DIDÁTICA NA PERSPECTIVA DE ZABALA (1998) .................. 106

5. EXPERIMENTAÇÃO: VIVENCIANDO UMA INVESTIGAÇÃO

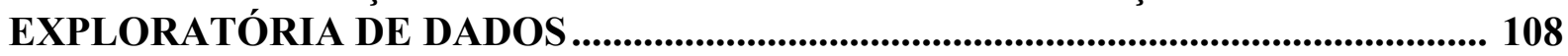

5.1 DELINEAMENTO DA QUESTÃO DE INVESTIGAÇÃO ....................................................... 109

5.2 ESTRUTURANDO A INSTRUMENTO DE Coleta de DAdOS ........................................... 111

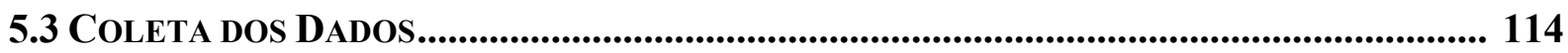

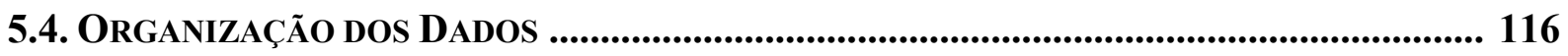

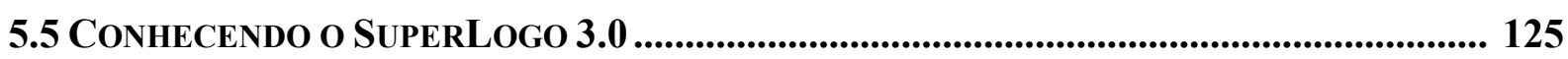

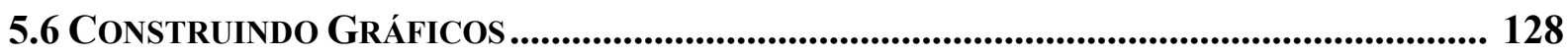

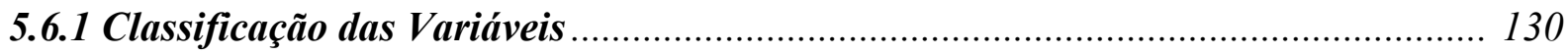

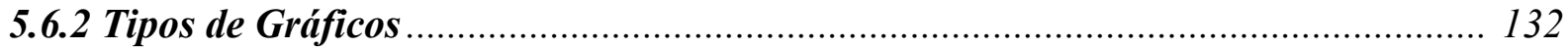

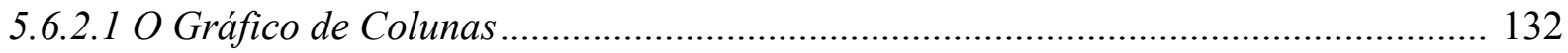




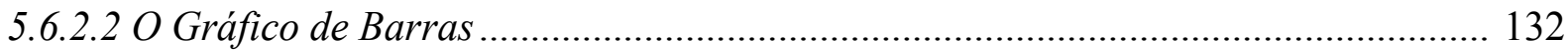

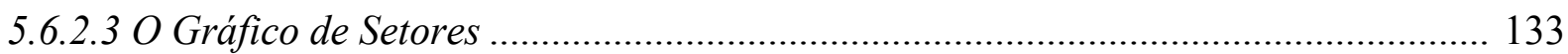

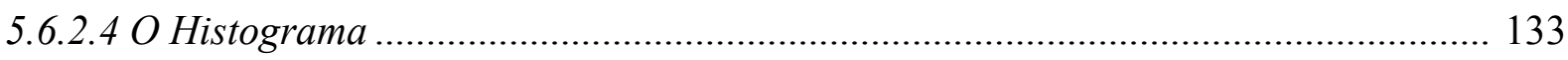

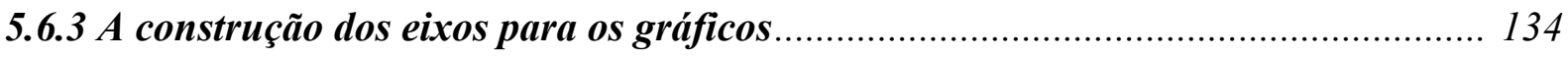

5.6.4 Locais de Uso do Computador: O Gráfico de Barras ............................................... 135

5.6.5 Distribuição das idades dos alunos: o Gráfico de Colunas .................................... 140

5.6.6 Distribuição entre Meninos e Meninas: O Gráfico de Setores................................. 142

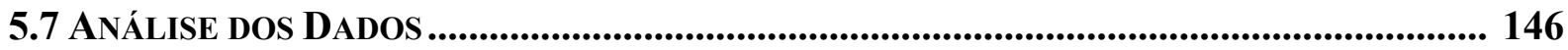

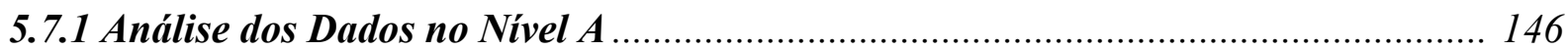

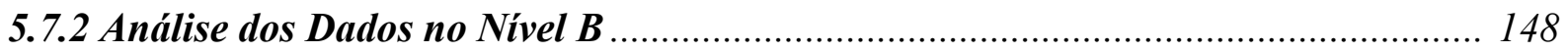

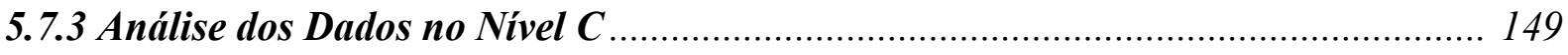

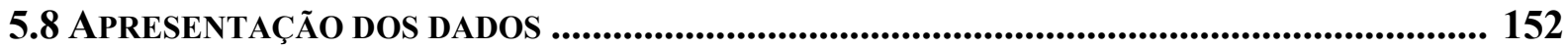

6 ANÁLISES FINAIS E CONSIDERAÇÕES ......................................................... 154

6.1 APRENDIZAGEM POR ADAPTAÇÃO.................................................................................... 154

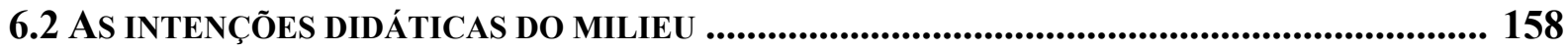

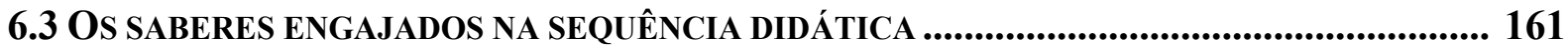

6.4 RESPONDENDO ÀS QUESTÕES DE INVESTIGAÇÃO ..................................................... 163

6.5. Considerações Finais e Perspectivas futuras...................................................... 173

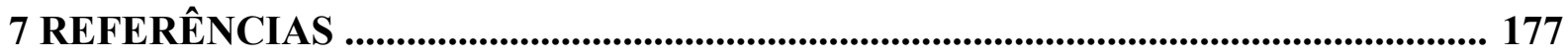

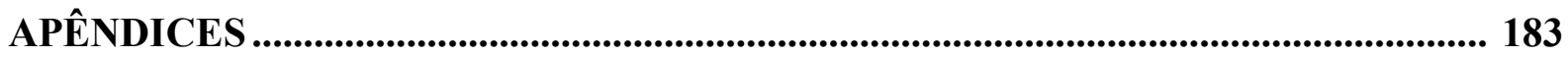

APÊNDICE A - INSTRUMENTO DIAGNÓSTICO ELABORADO A PARTIR DAS

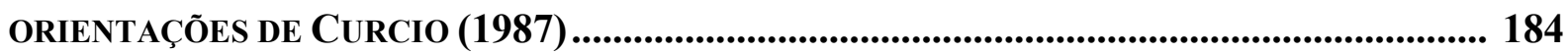

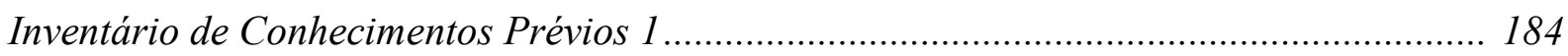

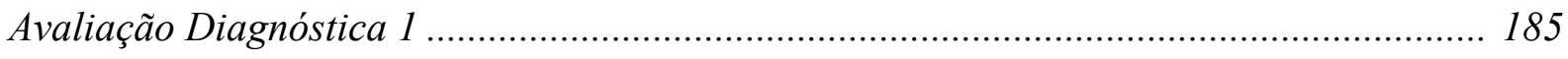

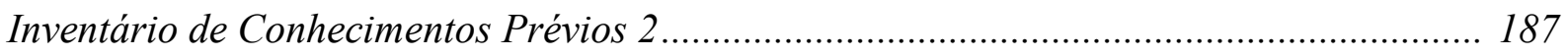

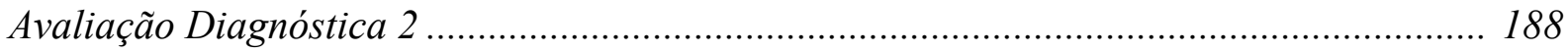

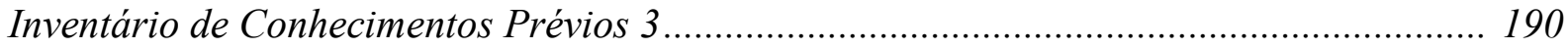

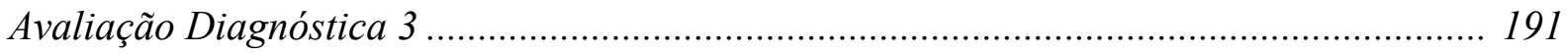

APÊNDICE B - TABELAS COM O DESEMPENHO dOS ALUNOS NA AVALIAÇÃo

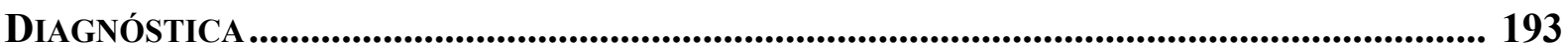

APÊNDICE C - InSTRumento de Coleta de DAdos elaborado pelos Alunos ...... 196 
APÊNDICE D - CARACTERIZAÇÃo dos AlunOS DA ESCOLA A PARTICIPANTES do

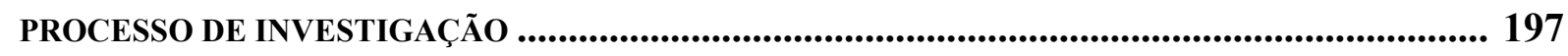

APÊNDICE E - CONHECENDO O SUPERLOGO 3.0 ........................................................... 198

APÊNDICE F - APRESEnTAÇão Final do Projeto PUblicada No Blog da

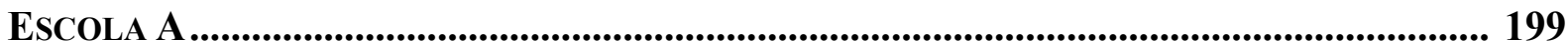

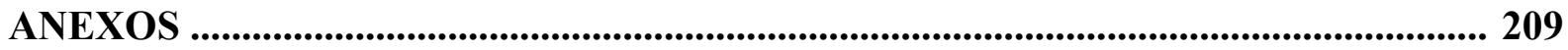

ANEXO 1 - Questões da Prova de Matemática da 8ª́ SÉrie do EF do SARESP

DE 2005 


\section{INTRODUÇÃO}

Iniciamos esta dissertação, explicitando os caminhos que nos trouxeram até aqui, por julgarmos que foram importantes e influenciaram o delineamento do tema e do problema de pesquisa.

Qual o fato gerador que move o interesse para investigar um determinado problema? Identificá-lo e esclarecê-lo representa nosso objetivo neste primeiro momento.

\subsection{As Vivências que Originaram o Problema de Pesquisa}

Os conceitos e habilidades relacionados à Estatística estão presentes há mais de 20 anos no currículo paulista, conforme evidencia a Proposta Curricular para o Ensino de Matemática no $1^{\circ}$ Grau de 1988 que, em meio ao bloco de conteúdos Números, sugere a abordagem de noções de Estatística na $8^{\mathrm{a}}$ série do Ensino Fundamental, contemplando o "levantamento e tabulação de uma amostra" e a "construção e interpretação de gráficos: histogramas, gráficos de barras, de setores, de linhas poligonais e de curvas" (SÃO PAULO, 1988, p. 25). Com a promulgação dos Parâmetros Curriculares Nacionais (PCN), essa relevância foi ratificada e os conceitos relacionados à Probabilidade, Estatística e Combinatória foram agrupados, constituindo um novo bloco de conteúdos ${ }^{1}$ denominado Tratamento da Informação. Embora essas informações sejam suficientes para evidenciar a importância da temática no ensino fundamental (e médio), há algum tempo, não temos recordações da abordagem de conceitos e habilidades relacionadas à Estatística em nossa formação básica, anterior à graduação. Semelhante constatação evidencia a relevância de se discutir o processo de ensino e aprendizagem de Probabilidade e Estatística, na medida em que diversas pesquisas têm apontado essa deficiência na maioria das salas de aula de nosso país, seja por falta de (in)formação dos professores ou pela desconsideração da pertinência desses conceitos para a formação do aluno.

No segundo ano do Curso de Licenciatura em Matemática, ano de 2004, tivemos nossa primeira experiência com Estatística, quando cursamos a única disciplina obrigatória do curso relacionada ao tema, denominada "Probabilidade e Estatística", alinhada à proposta do tratamento estocástico, isto é, o trabalho com Probabilidade e Estatística de

\footnotetext{
${ }^{1}$ Além dos blocos "Números e Operações", "Espaço e Forma" e "Grandezas e Medidas", contemplando conteúdos de Álgebra, Aritmética e Geometria.
} 
forma integrada. No entanto, além da limitação de tempo para tratar os conceitos e habilidades referentes ao tratamento de dados, a disciplina pautava-se por um caráter tecnicista, priorizando conceitos e princípios de Probabilidade e Estatística, muitas vezes, em detrimento das relações subjacentes e fundamentais à compreensão da variabilidade, essencial na Estatística, assim como se esquecendo do aspecto pedagógico relacionado à temática. Fica evidente, portanto, que a nossa experiência vai ao encontro das constatações de pesquisadores da área que afirmam:

A formação dos professores, atualmente, não incorpora um trabalho sistemático sobre estocástica, dificultando a possibilidade desses profissionais desenvolverem um trabalho significativo com essa temática nas salas de aula da educação básica (LOPES, 2008a, p. 70).

Apesar das limitações da disciplina, como trabalho de conclusão, foi solicitado que os alunos, divididos em grupos, realizassem estudos estatísticos comparativos entre o desempenho da turma de Licenciatura em Matemática do período noturno e as demais dos cursos de licenciatura da faculdade, ingressantes no ano de 2003, a partir dos dados do Vestibular divulgados pela Fundação Vunesp, órgão responsável pelo vestibular da Unesp. A proposta parecia interessante, já que possibilitava a aplicação de conceitos discutidos no decorrer do ano num conjunto de dados reais e com significado para os alunos.

Embora fosse possível vislumbrar um trabalho vantajoso, o que se efetivou contrapôs-se totalmente à proposta em questão. Os alunos não manifestaram nenhuma motivação para a atividade e, ao final, poucos trabalhos foram apresentados. A maioria não avaliava as análises solicitadas, e aquelas que foram realizadas pautaram-se apenas em cálculos, sem qualquer contextualização, que atribuísse sentido aos resultados numéricos obtidos.

Diante desse quadro e das conversas de corredor com os colegas, algo começou a nos inquietar. Por que (futuros) professores de Matemática não se interessam por uma área tão rica e importante quanto a Estatística? Como esses professores poderão lidar com essa temática em sala de aula, com uma formação tão "restrita” e engessada?

A última questão refere-se ao tratamento dado à Educação Estatística no processo de formação de professores, que nem sempre possibilita a vivência plena de investigações exploratórias, facilitadoras de atribuição de sentido às medidas e cálculos realizados para a apresentação, análise e interpretação de dados. Esse tipo de experiência torna possível a superação do caráter determinístico atribuído à Estatística, diferencial dessa ciência, quando comparada à Matemática. Assim, torna-se necessária uma discussão mais profunda e complexa do processo de formação de professores, pois 
Acreditamos que seja importante oportunizar ao futuro professor momentos para que ele possa aprender a construir e a comparar novas estratégias de ação, novas formas de pesquisa, novas teorias e categorias de compreensão, novos modos de definir problemas. Desse modo, o profissional poderá construir de forma idiossincrática o seu conhecimento profissional (CYRINO, 2006, p. 85).

A partir dessa inquietação, passamos, então, a buscar trabalhos e experiências que pudessem trazer subsídios e contribuições para responder às questões emergentes da situação ora descrita, ou a tantas outras semelhantes. Nesse percurso, deparamo-nos com os trabalhos de Lopes $(1998,2003)$, cujas concepções nos conduziram a um aprofundamento da investigação sobre o ensino e a aprendizagem na Educação Estatística, fato gerador desta pesquisa.

Quanto à tecnologia, nossa primeira experiência ocorreu na disciplina optativa do curso de Licenciatura em Matemática intitulada Ensino de Matemática por Múltiplas Mídias, orientada pela Prof. ${ }^{\text {a }}$ Dr. ${ }^{a}$ Maria Raquel Miotto Morelatti, no ano de 2006, cujo objetivo era apresentar e discutir os fundamentos que subsidiam a integração da tecnologia ao processo de ensino-aprendizagem matemática. As provocações da disciplina dinamizaram reflexões sobre as possibilidades e limitações dessa ferramenta como propulsora de um novo paradigma educacional. Assim, começamos a vislumbrar a urgência de um aprofundamento teórico-prático sobre questões educacionais, pensando no Mestrado em Educação.

Ao final do curso de graduação, fomos convidados a cursar, na qualidade de aluno ouvinte, a disciplina do Programa de Pós-Graduação em Educação Tecnologias de Informação e Comunicação e Educação Escolar, oferecida pelas Prof. ${ }^{a}$ Dr. ${ }^{a}$ Monica Fürkotter e Prof. ${ }^{a}$ Dr. ${ }^{a}$ Cláudia Maria de Lima. As profundas discussões realizadas na disciplina corroboraram as inquietações da graduação, levando-nos a pensar na possibilidade de se integrar a tecnologia ao contexto da Educação Estatística. Delineamos, então, mais um aspecto de investigação para esta pesquisa de mestrado: as possibilidades de uso da tecnologia no ensino de Estatística. 


\subsection{As pesquisas em Educação Estatística}

Para orientar nosso olhar e subsidiar o recorte do objeto de investigação, bem como, para aprofundar os conhecimentos sobre as concepções e teorias que fundamentam os estudos na área de Educação Estatística, buscamos pesquisas desenvolvidas até então.

Cabe salientar o escasso número de trabalhos encontrados com essa abordagem temática, principalmente em nosso país. Tal limitação ratifica a necessidade de investidura, por parte dos pesquisadores, seja no desenvolvimento de projetos de ensino e aprendizagem, seja na discussão de processos formativos de professores especialistas e não especialistas no que se refere à Educação Estatística.

Lopes, que desenvolveu uma pesquisa colaborativa com o objetivo de investigar as relações entre o conhecimento profissional dos professores e suas relações com Estatística e Probabilidade na Educação Infantil, concluiu que o grupo de educadoras, objeto da pesquisa,

[...] ora conjunta ora individualmente buscaram e experimentaram o que para elas e para seus alunos tivesse significado, comprovando que modelos prontos e objetivos bem definidos por outros no currículo não são eficazes, uma vez que reduzem a capacidade de juízo profissional do professor e sua possibilidade de aspiração educativa (2003, p. 236-237).

Santos (2005) investigou a forma de implementação do Tratamento da Informação por professores de Matemática do Ensino Fundamental e constatou que, na maioria das vezes, o trabalho limita-se às atividades e propostas apresentadas em livros didáticos, refletindo uma concepção errônea de uma visão tecnicista (utilitarista) e limitada da interpretação e análise de dados. Identificou, ainda, a necessidade de se investigar o pensamento e a aprendizagem estatística em todos os níveis de ensino, considerando que a maioria dos professores não passou do letramento estatístico funcional para o científico ${ }^{2}$, estágio que acarreta sérios problemas quanto ao conhecimento e formação dos conceitos da área.

Ribeiro (2007), ao investigar a leitura e a interpretação de gráficos e tabelas por professores especialistas e não especialistas em Matemática, comprovou a superioridade dos professores especialistas para compreender ideias e conceitos relacionados com o tema. Os resultados evidenciaram que as concepções e competências dos professores, especialistas e polivalentes, ainda se encontram vinculadas à visão tecnicista da Estatística, limitada à interpretação simples de conceitos básicos.

\footnotetext{
${ }^{2}$ Níveis de letramento estatístico propostos por Shamos (1995 apud GAL, 2002), que serão mais bem discutidos no próximo capítulo.
} 
Morais (2006), por sua vez, discutiu os componentes e habilidades do raciocínio estatístico de professores do Ensino Fundamental, quando concluiu que eles desenvolvem habilidades estatísticas propícias ao letramento no nível cultural, ao invés do "funcional" 3 adequado a esse segmento. Possivelmente, o resultado decorre da influência dos livros didáticos favorecedores de uma visão tecnicista da Estatística, porque priorizam o uso de registros tabelares e gráficos, e apenas a interpretação algorítmica do conceito de média aritmética.

Cazorla (2002) trabalhou com estudantes do ensino superior para investigar o domínio do conceito de média aritmética a partir da leitura de gráficos. A pesquisadora concluiu que os sujeitos dominavam o conhecimento procedimental da média aritmética, mas não o conceitual, uma vez que conheciam o algoritmo para o cálculo da média, mas não dominavam o conceito de média ponderada. Igual deficiência pode influenciar outras habilidades estatísticas. Por exemplo, a leitura de gráficos fica comprometida, na medida em que os equívocos na interpretação da média podem trazer conclusões contraditórias entre as informações dos resumos numéricos, quando comparados à representação gráfica.

Guimarães (2002) investigou a compreensão da leitura/interpretação de gráficos de barra, além da construção desse tipo de gráfico, a partir de dados apresentados em tabelas, bem como a relação entre uma e outra, em crianças de 09 e 10 anos. Constatou que os alunos apresentaram facilidade na leitura pontual de gráficos de barras. No entanto, demonstraram dificuldade para a interpretação variacional. O trabalho com escalas ficou comprometido em virtude da dificuldade dos alunos em interpretar valores contínuos, não explícitos, expressos em gráficos. Além disso, eles evidenciaram mais facilidade para construir e interpretar dados nominais que dados ordinais. Finalmente, a partir dos resultados obtidos, a autora concluiu que ler e interpretar dados parece ser mais fácil que construir gráficos. Cabe destacar que o referido trabalho não discute a capacidade de organização de dados, avaliando as formas mais adequadas, na medida em que só tratou de gráficos de barra.

Santos (2003) desenvolveu um estudo de caso com uma professora das séries iniciais do Ensino Fundamental, utilizando o ambiente computacional Tabletop, com o objetivo de investigar o processo de formação e desenvolvimento de conceitos matemáticos relacionados ao bloco Tratamento da Informação. Os resultados apontaram que a coleta e organização dos dados em tabelas são importantes e que o computador pode contribuir para o entendimento de gráficos e tabelas extraídos da manipulação desses dados. No entanto, o uso

\footnotetext{
${ }^{3}$ Idem.
} 
inadequado de seus recursos pode comprometer o estudo das representações dos dados e o desenvolvimento de outros conceitos.

Magina e Gitirana (1998) recorreram ao Tabletop para analisar as interpretações realizadas por 30 alunos de $5^{\mathrm{a}}$ e $6^{\mathrm{a}}$ séries sobre pictogramas construídos a partir de um banco de dados. Os resultados apontaram que a manipulação de dados representa um bom caminho para dar significado aos eixos cartesianos, assim como a fase de coleta de dados pelos próprios alunos é importante no momento da análise.

Lopes (1998) investigou e analisou o ensino da Probabilidade e da Estatística no contexto do currículo de Matemática no Ensino Fundamental. A pesquisadora salientou a importância desses temas para a formação do estudante, por possibilitarem uma ruptura com a visão determinista da Matemática. Além disso, afirmou que o ensino de Probabilidade e Estatística pode ser um amplo espaço de trabalho pedagógico interdisciplinar e, assim proporcionar, através da realização de experimentos, a exploração da ideia de acaso. Realizando observações, registros e representações de dados, os estudantes estarão aptos à leitura e à interpretação de informações diferenciadas. Os conceitos estatísticos funcionam como importantes "ferramentas" para a resolução de problemas. O trabalho com a probabilidade auxiliará os alunos na tomada de decisões. Como resultado, a pesquisadora enfatizou a necessidade de se proporem situações de aprendizagem que possibilitem o desenvolvimento do pensamento estatístico e probabilístico, uma vez que se busca a formação de um indivíduo que exerça consciente e criticamente sua cidadania.

Apesar de as pesquisas na área de Educação Estatística apresentarem números bastante modestos, apontam um amplo campo de investigação, o que possibilita um olhar para diversos aspectos relacionados aos conceitos e habilidades estatísticas e probabilísticas. Entretanto, parecem convergir para a necessidade de se proporcionar aos alunos - em todos os níveis de ensino, inclusive na Educação Superior - experiência durante a qual possam lidar com dados reais, num processo de investigação, perpassando todas as etapas: coleta, organização, apresentação, análise e interpretação de dados. Para tanto, é necessário estruturar uma situação-problema significativa para o aluno, de forma a contextualizar e atribuir sentido ao tratamento dos dados. Nesse contexto, delineamos nossa(s) questão(ões) de investigação. 


\subsection{Delineamento da(s) questão(ões) e objetivo(s) para a investigação}

Não se pode tangenciar a importância da Estatística e da Probabilidade em todos os níveis de ensino, bem como a necessidade de se repensarem as concepções teóricometodológicas e as práticas educativas desenvolvidas nas escolas concernentes, particularmente, ao bloco Tratamento da Informação.

Nesse contexto, nossa pesquisa começa a ganhar forma na medida em que delineamos a questão de investigação, subdividida em dois focos.

Quais características podem contribuir para que uma Investigação Exploratória de Dados possa, de fato, caracterizar uma situação de resolução de problema, de forma a possibilitar que os alunos atribuam sentido à Educação Estatística por meio da experiência de um processo de investigação?

Como a integração ${ }^{4}$ das Tecnologias de Informação e Comunicação (TIC) nessa Investigação Exploratória de Dados pode trazer contribuições para o processo estatístico, particularmente à atribuição de significado às informações representadas por meio de gráficos e tabelas?

Essas duas questões apontam para a relevância de elaborar, aplicar e analisar uma sequência didática pautada em uma investigação exploratória de dados, de forma a envolver os alunos num processo estatístico, abrangendo as três dimensões das intenções educativas: conceitual, por envolver conceitos estatísticos e matemáticos; procedimental, por pautar-se nos procedimentos relacionadas com a investigação; e atitudinal, por vislumbrar o desenvolvimento da capacidade crítica diante de dados e informações estatísticas presentes no dia-a-dia. Como forma de facilitar o processo de organização e representação dos dados, bem como a mediação do professor, acreditamos que as TIC possam trazer significativas contribuições às três dimensões. Nosso objetivo geral de pesquisa é, portanto, avaliar as características que podem contribuir para que uma investigação exploratória de dados represente uma situação-problema facilitadora no processo de ensino e aprendizagem, bem como, em que medida as TIC podem favorecer esse processo.

Como objetivos específicos da pesquisa, consideramos:

- investigar o nível de compreensão de conteúdos matemáticos implícitos no processo de leitura e interpretação de gráficos, quais sejam, coordenadas cartesianas, relação

\footnotetext{
${ }^{4}$ Utilizamos o termo integração por não acreditarmos que as TIC possam/devam ser inseridas nas escolas, mas sim integradas aos processos de ensino e aprendizagem.
} 
gráfico-dados, conjuntos, porcentagem, frequência, variação, ângulos, regra de três, razão, proporção e escalas;

- investigar as habilidades relacionadas à construção, à leitura e à interpretação de gráficos e tabelas, bem como os aspectos que influenciam a apropriação dessas habilidades pelos alunos, a partir do trabalho de Curcio $(1987)^{5}$ e dos níveis de letramento estatísticos de Shamos (1995 apud GAL, 2002);

- avaliar as contribuições de uma Investigação Exploratória de Dados à atribuição de significado aos conceitos estatísticos e ao processo de leitura e interpretação de gráficos e tabelas;

- investigar as potencialidades e limitações do software SuperLogo 3.0 para a construção de gráficos e para o desenvolvimento da capacidade de leitura e interpretação de gráficos.

\subsection{A Engenharia Didática como Metodologia de Pesquisa}

A investigação fundamenta-se em uma pesquisa de natureza empírica e de caráter qualitativo, visto que se pauta em atividades desenvolvidas com os alunos, em sala de aula e na Sala Ambiente de Informática (SAI) ${ }^{6}$, contemplando não apenas os dados finais, mas, principalmente, os fatos que ocorreram durante todo o processo de desenvolvimento das situações didáticas, numa perspectiva qualitativa. Trata-se de um trabalho de campo com aspectos que visaram à descoberta das dificuldades encontradas pelos alunos, bem como as possibilidades de melhoria na qualidade de aprendizagem quanto à construção, leitura e interpretação de gráficos e tabelas.

Para tanto, as atividades sustentaram-se na Engenharia Didática, metodologia constituída com a finalidade de analisar situações didáticas (MACHADO, 2008), aqui entendidas como

o conjunto de relações estabelecidas explicitamente e/ou implicitamente entre um aluno ou um grupo de alunos, um certo milieu $^{7}$ (contendo eventualmente instrumentos ou objetos) e um sistema educativo (o professor) para que esses alunos adquiram um saber constituído ou em constituição (BROUSSEAU, 1978 apud ALMOLOUD, 2007, p. 33).

\footnotetext{
${ }^{5}$ Esse trabalho será discutido no próximo capítulo.

${ }^{6}$ Utilizamos os softwares Microsoft Excel e SuperLogo 3.0, como será descrito nos capítulos que abordam a concepção da sequência e a descrição das atividades desenvolvidas.

${ }^{7}$ Conceito da Teoria das Situações Didáticas que será mais bem discutido no segundo capítulo, onde foi introduzido para analisar as relações entre alunos, conhecimento e situações.
} 
A Engenharia Didática, vista como metodologia de pesquisa, caracteriza-se por um esquema experimental baseado em atividades didáticas desenvolvidas em sala de aula, visando à aprendizagem.

Neste trabalho, especificamente, trata-se de um esquema constituído pela elaboração, realização, observação e análise de uma sequência didática, aqui entendida na concepção de Zabala (1998), o qual explicita que a ordenação articulada das atividades pode ser o elemento diferenciador das metodologias, sendo o primeiro aspecto característico de um método o tipo de ordem em que se propõem as atividades. A sequência considera a importância das intenções educacionais para a definição dos conteúdos de aprendizagem e o papel das atividades que são propostas. Alguns critérios para análise das sequências reportam que os conteúdos de aprendizagem agem explicitando as intenções educativas e, ao mesmo tempo, podem abranger as dimensões: conceituais; procedimentais; conceituais e procedimentais; ou conceituais, procedimentais e atitudinais, demonstrando que:

A engenharia didática envolve, além de estudos preliminares, a construção, exploração e análise de situações de aprendizagem que têm por objetivo relacionar o professor, os alunos e um elemento do saber matemático, objeto da aprendizagem (ALMOLOUD, 2007, p. 28).

Neste trabalho, pretendemos elaborar, aplicar e analisar uma sequência didática, de modo a possibilitar aos alunos a experiência de um processo estatístico, que envolva as três dimensões das intenções educativas: conceitual, procedimental e atitudinal.

Artigue (1988 apud ALMOULOUD; COUTINHO, 2008) apresenta a metodologia da Engenharia Didática comparando-a ao trabalho do engenheiro. Ao realizar um projeto, apoiando-se sobre o conhecimento científico de seu domínio, o engenheiro, assim como o professor ou pesquisador, aceita submeter-se a um controle científico e, ao mesmo tempo, obriga-se a trabalhar sobre objetos mais complexos que os científicos.

Nessa direção, o professor, ao elaborar ou escolher uma sequência didática, deve levar em conta, de forma integrada: o domínio do conhecimento, o conhecimento prévio do aluno, o papel do professor e dos alunos. Para tanto, em cada sequência, fica patente a definição do significado da aprendizagem. A criação de uma sequência didática ocorre por meio de um processo interativo, em que o objetivo significa a elaboração de um grupo de decisões para que os processos tenham significado e as estratégias sejam mais efetivas. As respostas dos alunos e as condições a que estão submetidos são levadas em consideração durante a elaboração das atividades. O processo envolve uma análise da situação proposta, das condições da organização, da escolha de estratégias baseadas nas análises da instrução dada, 
da determinação de critérios de avaliação, da elaboração de questões que estejam de acordo com os critérios determinados e de uma revisão de todo o processo em função desta avaliação.

Segundo Machado (2008), o processo experimental da Engenharia Didática é composto de quatro fases:

- análises preliminares - fundamentadas no quadro teórico, contemplam uma análise epistemológica dos conteúdos, do quadro atual do ensino, da concepção dos alunos, das dificuldades e dos possíveis entraves que podem ser encontrados na efetiva realização didática;

- concepção e análise a priori das situações didáticas - descrição das escolhas e características das situações, análise dos desafios para o aluno e dos possíveis comportamentos de modo a prever as contribuições das atividades para o desenvolvimento do conhecimento;

- experimentação - explicitação dos objetivos e condições de realização da pesquisa aos alunos, estabelecimento do contrato didático ${ }^{8}$, aplicação dos instrumentos de pesquisa e o registro das observações;

- análise a posteriori e validação: tratamento dos dados coletados e complementação desses dados (se necessário), de forma a viabilizar o confronto entre as hipóteses levantadas na análise a priori com as experiências efetivamente ocorridas no desenvolvimento da pesquisa. "É da confrontação das análises a priori e a posteriori que se validam ou refutam as hipóteses levantadas no início da engenharia” (MACHADO, 2008, p. 246).

\subsection{Caracterização da Unidade Escolar e do Grupo de Alunos Investigados}

O processo de inserção no ambiente selecionado para o desenvolvimento da pesquisa teve início antes do ingresso no Programa de Pós-Graduação, a partir da realização do estágio desenvolvido durante a graduação, no ano de 2006. Ao longo do texto, pretendemos expor as características de estrutura física, administrativa e pedagógica desse ambiente escolar, fatores que influenciaram nossa permanência nesta escola.

Em 2007, retornamos à mesma escola para elaborar um trabalho vinculado à disciplina Tecnologias de Informação e Comunicação e Educação Escolar, com base na

\footnotetext{
${ }^{8}$ Definido por Brousseau (1986 apud ALMOLOUD, 2007) como o conjunto de comportamentos do professor esperado pelos alunos e dos alunos esperado pelo professor. Representa uma relação que determina, sobretudo de forma implícita, aquilo que cada parceiro tem a responsabilidade de gerir e pelo qual será responsável perante o outro.
} 
técnica de pesquisa qualitativa conhecida como "Grupo Focal", em cujo desenvolvimento buscamos identificar as Representações Sociais dos alunos de uma $5^{\text {a }}$ série do Ensino Fundamental sobre o potencial pedagógico do computador, no processo de aprendizagem escolar. Assim, desenvolvemos uma investigação inicial nesse ambiente escolar.

Trata-se de uma escola estadual localizada em uma cidade de pequeno porte no interior do estado de São Paulo. Para preservar sua identidade, será aqui tratada por Escola A.

A análise de documentos oficiais dessa unidade escolar e uma entrevista semiestruturada com a coordenadora pedagógica revelaram que ela funciona nos períodos diurno e noturno, para atender alunos do Ensino Fundamental, ciclo II ( $5^{\mathrm{a}}$ a $8^{\mathrm{a}}$ séries $)$, que estudam em tempo integral, quer dizer, das $7 \mathrm{~h} 10 \mathrm{~min}$ às $15 \mathrm{~h} 50 \mathrm{~min}$.

O Projeto Escola de Tempo Integral foi instituído no Estado de São Paulo por meio da Resolução SE nº 89, de 09 de dezembro de 2005,

[...] com o objetivo de prolongar a permanência dos alunos de ensino fundamental na escola pública estadual, de modo a ampliar as possibilidades de aprendizagem, com o enriquecimento do currículo básico, a exploração de temas transversais e a vivência de situações que favoreçam o aprimoramento pessoal, social e cultural (SÃO PAULO, 2005, p. 1).

A escola também oferece o Ensino Supletivo (Ensino Fundamental e Médio) no período noturno e Ensino Médio, nos períodos matutino e noturno.

Por esse motivo, a escola conta com mais de 100 docentes, dos quais 89 têm sede nela, sob a orientação e colaboração de um diretor, dois vice-diretores (um deles decorrente do tempo integral) e três coordenadoras, uma para o período diurno, outra para o período noturno e uma terceira para o período integral.

O corpo discente é composto por aproximadamente 1330 alunos, distribuídos nos períodos de funcionamento da escola.

A estrutura física da escola distribui-se em 21 salas de aula, que atendem em média a 35 alunos por turma, no Ensino Fundamental, e a 40, no Ensino Médio.

De acordo com a coordenadora, a Escola A está localizada em um bairro "bom" da cidade. A maioria dos alunos provém de "classe média, de famílias estruturadas, sendo pequeno o índice de alunos oriundos de família de baixa renda, com desempenho abaixo da média, ou com histórico de agressividade e desajuste emocional" (informação verbal) ${ }^{9}$.

Em relação às condições das instalações escolares, a escola A dispõe de:

$\rightarrow$ uma sala de vídeo;

\footnotetext{
${ }^{9}$ Informação verbal da coordenadora da escola, mediante entrevista semiestruturada.
} 
$\rightarrow$ uma sala de leitura (biblioteca), com aproximadamente dez mil livros;

$\rightarrow$ um laboratório de Química e Física;

$\rightarrow$ uma Sala Ambiente de Informática (SAI), com treze microcomputadores em rede e com Internet.

A escola conta com dois televisores móveis, uma máquina fotográfica digital, um retroprojetor, um projetor multimídia e um aparelho de som, que, inclusive, é usado pelos alunos, nos intervalos das aulas, como atividade recreativa organizada pela "Rádio Galera".

Possui uma ampla dimensão territorial, com uma quadra poliesportiva coberta e duas quadras descobertas. As salas de aula usuais são discriminadas por numeração e não há sala ambiente distinguida pelas disciplinas.

A escola procura realizar atividades diferenciadas, por meio de projetos que abordam temas interdisciplinares, tais como meio ambiente, cidadania, sexualidade, arte e cultura.

A estrutura curricular do Ensino Fundamental é constituída pelas disciplinas básicas: Língua Portuguesa, Matemática, História, Geografia, Ciências Físicas e Biológicas e Educação Física. Dentro do Programa de Escola em Tempo Integral, também são oferecidas as Oficinas de:

$\rightarrow$ Saúde e Qualidade de Vida;

$\rightarrow$ Artes, em que são realizadas atividades de dança, música, teatro e artesanato;

$\rightarrow$ Orientação para estudo e pesquisa, que, segundo a coordenadora, é empregada para o aprofundamento dos conteúdos trabalhados em sala de aula, visto que não há "tarefa para casa", em decorrência do tempo integral;

$\rightarrow$ Experiências Matemáticas, em cujas atividades a professora procura desenvolver projetos com novas abordagens de ensino dos conteúdos matemáticos;

$\rightarrow$ Informática Educacional, cujos projetos objetivam introduzir o uso do computador no processo de ensino e aprendizagem de diferentes conteúdos escolares.

$\mathrm{Na}$ Sala Ambiente de Informática (SAI), utilizada nas atividades, funcionam apenas dez dos treze computadores existentes. A SAI também conta com uma mesa central, que alguns alunos utilizam para desenvolver outras atividades, enquanto os demais trabalham nos computadores. 
Apesar de o desenvolvimento do projeto de pesquisa ter sido acordado no ano de 2008, enfrentamos muitas dificuldades para efetivá-lo, tendo em vista que a Coordenação e Direção da Escola A sofreram mudanças no período 2008-2009, o que dificultou a realização da atividade que só foi possível após apresentação do projeto às novas Coordenadora Pedagógica e Diretora, e aos Professores das Oficinas de Experiências Matemática e Informática Educacional. Ainda assim, tivemos problemas para finalizar as atividades, pois, em meio ao desenvolvimento do projeto, a SAI da Escola A foi desativada para fins de reforma, o que nos obrigou a encontrar alternativas para sua finalização. Conforme será descrito no $4^{\circ}$ Capítulo, o trabalho foi finalizado no Laboratório Didático de Informática de uma unidade local da Unesp. Para tanto, estabelecemos parcerias com essa Instituição e com a Secretaria Municipal de Educação da cidade na qual a Escola A se localiza.

Optamos por desenvolver e aplicar a sequência didática numa $8^{\mathrm{a}}$ série do EF da Escola A, escolhida de forma aleatória. Essa sala era constituída de 32 alunos, mas apenas 27 deles apresentavam frequência regular. Desses 27, 12 eram do sexo masculino e 15 do sexo feminino. A idade predominante era 14 anos (24 alunos), com três deles já com 15 anos.

Pudemos constatar, no decorrer das atividades, que, nessa sala, os alunos provinham de "classe média", apenas dois alunos eram repetentes e poucos tinham famílias desestruturadas, corroborando as informações fornecidas pela professora coordenadora.

Conversando com os alunos, constatamos que 20 deles possuíam computador, sendo que apenas um disse não utilizar a ferramenta com frequência, já que aqueles que não tinham computador em casa informaram que faziam uso dele na escola, em lan houses, cybers e em casa de amigos e/ou parentes. Dos 27 alunos, 23 possuíam celular. Essas informações apontaram a importância e a forte presença da tecnologia (particularmente do computador e do celular) no cotidiano dos alunos, o que facilitou o direcionamento posterior das atividades.

Para realização da sequência didática, utilizamos as Oficinas de Informática Educacional e Experiências Matemáticas, do Programa Escola de Tempo Integral, cujo objetivo representa a abordagem de conceitos matemáticos por meio de metodologias diferenciadas e inovadoras, visando à correção de fluxo e ao desenvolvimento de habilidades e competências deficitárias. 


\subsection{Estrutura da Dissertação}

Elucidadas preliminarmente as ideias que fundamentaram nossas concepções e que nortearam nossas discussões, apresentamos a estrutura organizacional do trabalho.

No segundo capítulo, fazemos um aprofundamento teórico de conceitos e ideias utilizados no decorrer do trabalho, visando a tornar claras as considerações aqui apresentadas, bem como a criar subsídios para as atividades que comporão as etapas da sequência didática.

No terceiro capítulo, iniciamos as etapas da Engenharia Didática, por meio das análises a priori. Discutimos as orientações e propostas presentes nos Parâmetros Curriculares Nacionais (PCN), na Proposta Curricular do Estado de São Paulo (PCSP) e seus cadernos, no Guidelines for Assessment and Instruction in Statistics Education (GAISE) Report: a Pré-K12 Curriculum Framework e tecemos algumas considerações sobre livros didáticos. Além disso, informamos os resultados da Escola A nas avaliações do Sistema de Avaliação de Rendimento Escolar do Estado de São Paulo (Saresp) e na Prova Brasil. Ao final, organizamos e aplicamos um instrumento diagnóstico, também discutido e analisado, o qual também subsidiou a elaboração da sequência.

No quarto capítulo, estruturamos as etapas que compõem a sequência didática, explicitando as concepções e fundamentos que orientaram nossas escolhas, a partir dos pressupostos teóricos apresentados no segundo capítulo, da mesma forma das constatações da análise realizada no terceiro.

O quinto capítulo enfatiza a descrição pormenorizada da aplicação da sequência em sala de aula, de acordo com as etapas estruturadas no capítulo anterior.

No sexto e último capítulo, expressamos as análises e considerações acerca do trabalho desenvolvido. 


\section{PRESSUPOSTOS TEÓRICOS PARA A PESQUISA}

Objetivando explicitar as ideias e pressupostos que fundamentam este trabalho, expomos um quadro preliminar com conceitos e teorias utilizados. Para não engessar sua apresentação, as ideias aqui presentes serão retomadas, contextualizadas e aprofundadas no decorrer do trabalho.

\subsection{Educação Estatística}

$\mathrm{Na}$ sociedade da informação atual ${ }^{10}$, deparamo-nos cotidianamente com um grande volume de informações disponibilizadas pelas diversas mídias, demandando conhecimento para tratá-las adequadamente. É fundamental saber representar, analisar e questionar os dados disponíveis. Em decorrência disso, surge, em meio à educação básica, a necessidade de fazer com que o aluno construa procedimentos para interpretar os dados que aparecem frequentemente no seu dia-a-dia. Nesse contexto tem origem a Educação Estatística, área que estuda os problemas relacionados ao ensino e à aprendizagem de conceitos estatísticos e probabilísticos, apresentando uma interseção com a Educação Matemática, à medida que utiliza alguns conceitos matemáticos, ainda que se diferencie substancialmente dessa ciência, principalmente, no que concerne ao determinismo matemático, que se contrapõe ao caráter variável das questões estatísticas. Trata-se da área em que representações como tabelas, gráficos e percentuais tornam possíveis a escrita, leitura e interpretação de dados.

Um dos aspectos a ser considerado no processo de escolarização formal é o fato de estarmos expostos constantemente a um grande volume de informações apresentadas por meio de gráficos e tabelas que, para análise e compreensão crítica, demandam noções básicas de Estatística (CAMPOS, 2005). Trata-se da noção de competência em estatística.

\footnotetext{
$10 \mathrm{O}$ novo modelo de organização da sociedade fundamenta-se num modo de desenvolvimento social e econômico, onde a informação, como meio de criação de conhecimento, desempenha um papel fundamental na produção de riqueza e na contribuição para o bem-estar e qualidade de vida dos cidadãos. Uma condição para a sociedade da informação avançar é a possibilidade de todos poderem aceder às Tecnologias de Informação e Comunicação (aqui entendidas como todas as tecnologias que interferem e/ou mediam os processos informacionais e comunicativos), presentes no nosso cotidiano, as quais constituem instrumentos indispensáveis às comunicações pessoais, de trabalho e de lazer.
} 
Abordamos, assim, a perspectiva de Shaughnessy $(1992,1997)$ sobre o que é ser competente em Estatística, que é essencial aos cidadãos das sociedades atuais para ser crítico em relação à informação disponível; para entender e comunicar com base nessa informação; mas, também, para tomar decisões atendendo ao fato de que uma grande parte da organização dessas mesmas sociedades é feita com base nesses conhecimentos (LOPES; COUTINHO, 2009, p. 66).

Quando os estudantes constroem conhecimento estatístico significativo, eles se tornam capazes de questionar a validade de representações e interpretações de dados elaboradas por outros, bem como de generalizações realizadas a partir de um único estudo e/ou de amostras pequenas (GARFIELD; GAL, 1999).

Acreditamos que se trata do "surgimento" de um novo modelo de linguagem presente em todas as relações e áreas de atuação, como alternativa para ampliar as potencialidades de tratamento de dados de experimentos e observações. Dessa forma,

Consideramos que o ensino da Probabilidade e da Estatística de fato pode contribuir para que a escola venha a cumprir seu papel de preparar os estudantes para a realidade à medida que desenvolve a elaboração de questões para responder a uma investigação, que possibilita fazer conjecturas, formular hipóteses, estabelecer relações, processos necessários à resolução de problemas (LOPES, 2008b, p. 67).

Cabe esclarecer que concebemos problemas na perspectiva de Pólya (1986), que afirma que uma pessoa tem um problema quando procura conscientemente uma certa ação apropriada para obter um objetivo claramente concebido, mas não atingível de maneira imediata.

É preciso entender também que problema não é um exercício de aplicação de conceitos recém trabalhados, mas o desenvolvimento de uma situação que envolve interpretação e estabelecimento de uma estratégia para resolução (LOPES, 1998 apud LOPES, 2008b, p. 79).

Dessa forma, não podemos pautar os conteúdos atrelados ao bloco Tratamento da Informação dos PCN a definições restritas e limitadas, ou à simples coleta, organização e representação de dados, tendo em vista que essa prática não proporciona a efetiva aprendizagem e o desenvolvimento crítico do indivíduo. É preciso atribuir um sentido, um significado que parta de uma problemática para a coleta de dados (LOPES, 1998).

A resolução de problemas é fundamental aos alunos da educação básica, pois é essencial que eles se confrontem com problemas variados do mundo real e que tenham possibilidades de escolherem suas próprias estratégias para solucioná-los. Da mesma forma, é importante que eles problematizem situações diversas e redijam enunciados a serem confrontados por outros (LOPES; CARVALHO, 2009, p. 89).

Além disso, é necessário salientar que, apesar de convergir, em alguns aspectos educacionais, para os princípios matemáticos, é "preciso experimentar e avaliar métodos de ensino adaptados à natureza específica da estatística, pois a ela nem sempre se podem 
transferir os princípios gerais do ensino da matemática" (BATANERO, 2001, p. 06, tradução nossa).

Batanero (ibidem) concebe a Estatística como uma ciência e salienta a necessidade de se investigar e estruturar uma didática específica para ela que atinja suas especificidades em meio à Didática da Matemática, considerando a complexidade que envolve a compreensão dos princípios de incerteza e aleatoriedade, muitas vezes caracterizadores das dificuldades de fundamento filosófico no desenvolvimento do pensamento estatístico e os demais conceitos relacionados, já que esses se diferenciam substancialmente quanto ao determinismo matemático.

\begin{abstract}
A natureza da Estatística é muito diferente da cultura determinística tradicional da matemática. Um indicador disso é que ainda hoje em dia persistem controvérsias filosóficas sobre a interpretação e aplicação de conceitos básicos como os de probabilidade, aleatoriedade, independência ou testes de hipóteses, enquanto estas controvérsias não existem em álgebra ou geometria. As dimensões políticas e éticas de uso e possível abuso da estatística e da informação estatística contribuem para a especificidade de seu campo (BATANERO, 2001, p. 07, tradução nossa).
\end{abstract}

Na verdade, a grande diferença da Estatística para a Matemática está na onipresença da variabilidade, característica daquela que ultrapassa esta. A resolução de um problema estatístico e a tomada de decisão dependem da compreensão e explicação da variabilidade dos dados, sendo que em níveis mais avançados de ensino, a variabilidade necessita ser quantificada de forma a garantir a validade do modelo (ASA, 2005).

Gal e Garfield fazem a distinção entre as duas disciplinas da seguinte maneira:

- Na Estatística, os dados são vistos como números com um contexto, que motiva os procedimentos e funciona como fonte de significado e de base para a interpretação dos resultados de tais atividades.

- A indeterminação ou "bagunça" dos dados distingue investigações estatísticas de outras mais precisas, de natureza finita, caracterizando explorações matemáticas.

- Conceitos e procedimentos matemáticos são utilizados como parte da solução dos problemas estatísticos. No entanto, a necessidade de uma rigorosa aplicação da computação está sendo rapidamente substituída pela necessidade de uso seletivo, cuidadoso e preciso de ferramentas tecnológicas e softwares cada vez mais sofisticados.

- Muitos problemas estatísticos não têm uma única solução matemática, mas em vez disso, começam com uma questão e terminam em uma opinião apoiada por algumas conclusões e suposições. As respostas têm de ser avaliadas em termos de qualidade do raciocínio, de adequação dos métodos utilizados e de natureza dos dados e das provas utilizadas (1997 apud GARFIELD, 2003, p. 23, tradução nossa).

Garfield (1995) aponta alguns princípios da aprendizagem estatística na perspectiva construtivista de ensino. Segundo a autora, os alunos aprendem fazendo, com participação efetiva na a construção de seu conhecimento, já que tendem a fazer bem aquilo em que vislumbram uma aplicação prática. No que concerne aos erros e equívocos, Garfield afirma que os professores não devem subestimar as dificuldades dos alunos no âmbito da 
compreensão de conceitos básicos de Probabilidade e Estatística, tendo em vista que a aprendizagem é ressaltada quando os alunos que apresentam concepções equivocadas assumem e enfrentam essas dificuldades. Afirma, ainda, que calculadoras e computadores devem ser utilizados para ajudar os estudantes na visualização e na exploração de dados, não apenas para seguir algoritmos para fins pré-determinados. Salienta, também, a necessidade de interação no processo de avaliação, porque os alunos aprendem melhor quando recebem comentários úteis e consistentes sobre seu desempenho. No entanto, tendem a atribuir valor apenas àquilo que sabem que será avaliado. Reside aí a necessidade de se repensarem os processos de avaliação. Por fim, a autora afirma que a utilização de métodos de ensino não irá assegurar a aprendizagem de todos os estudantes, posto que nenhum método é perfeito e a aprendizagem sofre influência de alguns fatores subjetivos.

Garfield e Gal (1999) estruturaram alguns objetivos para a educação estatística, sendo eles: entender o propósito, a lógica e o processo de investigações estatísticas, aprimorar habilidades procedimentais, entender as relações matemáticas presentes, entender probabilidade e chance, desenvolver habilidades interpretativas e alfabetização estatística e desenvolver habilidades para comunicar estatisticamente. O desenvolvimento dessas habilidades torna possível atribuir sentido ao estudo de processos e conceitos estatísticos, bem como entender as especificidades presentes neles. Além disso, por meio do processo de familiarização com as etapas pelas quais perpassa uma investigação (formular uma pergunta; planejar um estudo; coletar; organizar e analisar dados; interpretar descobertas e discutir conclusões e implicações de descobertas), descobre-se as possíveis interferências que podem afetar e comprometer um dado resultado. Na verdade, o objetivo maior da Educação Estatística é “desenvolver as habilidades de raciocínio estatístico nos estudantes capacitandoos a produzir e a comunicar descrições, julgamentos, inferências e opiniões sobre informações de maneira significativa para eles" (ibidem, p. 211, tradução nossa).

Salienta-se, também, a importância de se articularem Probabilidade e Estatística, haja vista que

[...] a articulação com a Estatística é fundamental para o desenvolvimento do pensamento probabilístico, uma vez que se trabalha com a problematização, a realização do experimento, a coleta e a organização dos dados, antes de sua interpretação em termos de uso das frequências relativas como estimativa dos valores de probabilidade do evento que se quer observar (LOPES; COUTINHO, 2009, p.66).

Portanto, acreditamos que o trabalho com Educação Estatística deve estar fundamentado em problemas significativos para os alunos, de forma a envolvê-los num processo exploratório de investigação, articulando Probabilidade e Estatística, tendo em vista 
que a ideia diferenciadora do caráter determinístico da Matemática é a variabilidade presente em qualquer situação de estudo estatístico.

\subsubsection{Educação Estatística no Ensino Fundamental}

Nos Parâmetros Curriculares Nacionais (PCN) (BRASIL, 1997), os conceitos e procedimentos relacionados à Probabilidade, Estatística e Combinatória encontram-se agrupados no bloco "Tratamento da Informação". Os PCN, assim como algumas pesquisas, sugerem que a abordagem desses conteúdos deve estar presente em todo o processo escolar, desde a Educação Infantil, a fim de proporcionar às crianças a observação de situações de incerteza e o desenvolvimento do raciocínio combinatório que lhes permita reconhecer, organizar e representar informações (LOPES, 2003).

O referido documento orientador considera que abordar esses conteúdos nas dimensões conceitual, procedimental e atitudinal representa exigência fundamental na atualidade, porque estar alfabetizado na sociedade contemporânea supõe, além da aquisição da leitura e escrita formal,

[...] saber ler e interpretar dados apresentados de maneira organizada e construir representações, para formular e resolver problemas que impliquem o recolhimento de dados e a análise das informações. Essa característica da vida contemporânea traz ao currículo de Matemática uma demanda em abordar elementos da estatística, da combinatória e da probabilidade, desde os ciclos iniciais (BRASIL, 1997, p. 132).

O currículo do Estado de São Paulo, em implantação a partir de 2008, atribui significativa importância ao Tratamento da Informação na formação escolar, já que considera que sua utilização viabiliza o desenvolvimento da interpretação, reflexão e aplicação de conceitos matemáticos no cotidiano, tornando-os mais significativos e próximos do aprendiz. A proposta salienta, ainda, que a representação de dados e o Tratamento da Informação podem abrir espaço para a incorporação crítica das Tecnologias de Informação e Comunicação (TIC) no ensino, visto que sua fundamentação alicerça-se no desenvolvimento de competências elaboradas a partir de três eixos norteadores da ação educacional, a saber, expressão/compreensão, argumentação/decisão e contextualização/abstração.

O eixo expressão/compreensão: a capacidade de expressão do eu, por meio das diversas linguagens, e a capacidade de compreensão do outro, do não-eu, do que me complementa, o que inclui desde a leitura de um texto até a compreensão de fenômenos históricos, sociais, econômicos, naturais etc.

O eixo argumentação/decisão: a capacidade de argumentação, de análise e de articulação das informações e relações disponíveis, tendo em vista a construção de consensos e a viabilização da comunicação, da ação comum, além da capacidade de decisão, de elaboração de sínteses dos resultados, tendo em vista a proposição e a realização da ação efetiva. 
O eixo contextualização/abstração: a capacidade de contextualização, de enraizamento dos conteúdos estudados na realidade imediata, nos universos de significações - sobretudo no mundo do trabalho - e a capacidade de abstração, de imaginação, de consideração de novas perspectivas, de potencialidades no que ainda não existe (SÃO PAULO, 2008, p. 42).

A importância do Tratamento da Informação na formação escolar é ratificada pelo Guidelines for Assessment and Instruction in Statistics Education (GAISE) Report: a Pré-K-12 Curriculum Framework, aprovado pela Associação Americana de Estatística (American Statistical Association - ASA), em agosto de 2005, que apresenta a Literacia Estatística $^{11}$ como objetivo principal da Educação Estatística, na medida em que nossas vidas são orientadas por números e informações que necessitam de um raciocínio estatístico adequado para lidar de forma inteligente com exigências relacionadas à cidadania, emprego e família, a fim de subsidiar uma vida saudável e produtiva (ASA, 2005). Esse documento confirma a necessidade de se desenvolver a análise de dados a partir de questões que possam ser tratadas por meio da coleta, organização e apresentação de dados, ao mesmo tempo em que enfatiza a seleção e utilização de métodos e ferramentas adequados para desenvolver e avaliar inferências e predições. Por outro lado, destaca a importância da problematização por parte dos próprios estudantes de modo a facilitar o processo de tomada de decisão e retirada de conclusões (LOPES, 2008a).

Ratifica-se, portanto, a necessidade de se articular a Educação Estatística com o processo de resolução de problemas com significado, levando em conta a formação de conceitos, a criação e a apropriação de procedimentos e a aquisição de atitudes frente à necessidade de raciocinar probabilística e estatisticamente.

\begin{abstract}
A Educação Estatística não apenas auxilia na leitura e interpretação de dados, mas fornece a habilidade para que uma pessoa possa analisar/relacionar criticamente os dados apresentados, questionando/ponderando até mesmo sua veracidade. Para que se atinja essa etapa da criticidade não é suficiente oferecermos aos alunos apenas atividades de ensino que visem desenvolver a capacidade de organizar e representar uma coleção de dados, faz-se necessário interpretar e comparar esses dados para tirar conclusões (LOPES, 2008a, p. 73).
\end{abstract}

Para comparar esses dados, faz-se necessário o desenvolvimento do raciocínio e do pensamento estatístico, termos relacionados com o conceito de literacia estatística.

\footnotetext{
11 Termo que remete à capacidade de lidar com informações estatísticas do dia-a-dia. Seu componente significativo será aprofundado e ampliado mais adiante.
} 


\subsubsection{Literacia Estatística}

O termo literacia remete-nos à habilidade de ler, compreender, analisar e interpretar textos escritos. A literacia estatística, portanto, refere-se à habilidade de argumentar utilizando corretamente terminologias e conceitos estatísticos. No entanto, a definição para o termo encontra muitas variações dentre os pesquisadores. Algumas delas são apontadas no trabalho de Rumsey (2002) e descritas abaixo.

Para Gal (2000 apud Rumsey, 2002) literacia estatística é a capacidade de as pessoas interpretarem e avaliarem criticamente as informações estatísticas e os argumentos baseados em dados constantes de diversos canais de mídia. Ela engloba também a habilidade de discutir as opiniões sobre as informações estatísticas.

Garfield (1999 apud ibidem) afirma que o conceito refere-se à compreensão da linguagem e da terminologia estatística: palavras, símbolos e termos, relacionando-se, portanto, àquela de interpretar gráficos e tabelas, de forma a compreender (atribuir sentido) as informações estatísticas presentes nas notícias das mídias em geral.

Snell (1999 apud ibidem) já entende que literacia estatística significa a capacidade de compreender conceitos e razões estatísticas no nível mais básico.

Watson (1997 apud ibidem) concebe a literacia como sendo a capacidade de compreensão do texto e do significado das implicações das informações estatísticas no contexto do tema a que (ela) pertence, identificando três estágios para seu desenvolvimento:

(i) a compreensão básica da terminologia estatística;

(ii) a compreensão da linguagem e dos conceitos estatísticos inseridos no contexto de um debate social; e

(iii) o desenvolvimento de atitudes de questionamento nas quais se aplicam conceitos sofisticados para contradizer declarações que são feitas sem fundamentação estatística apropriada.

A literacia pode ser representada, portanto, como o entendimento e a interpretação de informações estatísticas, tendo em mente que, apesar de não ser consensual, todas as concepções, de alguma maneira, apontam para a capacidade de conviver com dados e informações estatísticas, presentes nas diversas mídias.

No entanto, tal processo envolve diversos aspectos, havendo a necessidade de o indivíduo mobilizar outras capacidades correlatas, de forma a promover a compreensão plena das idéias desse contexto, em que acreditamos ser importante discutirmos dois conceitos 
relacionados, que sustentam a compreensão da literacia estatística: o pensamento estatístico (statistical thinking) e o raciocínio estatístico (stastistical reasoning).

Snee (apud SILVA, 2007) define pensamento estatístico como o processo pelo qual o pensamento reconhece a presença da variabilidade em torno de tudo, sendo composto pelos seguintes elementos: reconhecimento da variação presente em todo o processo, necessidade de dados para mediar a variação e o uso de métodos e ferramentas estatísticos para quantificar e entender essa variação, permitindo uma tomada de decisão.

[...] a literacia estatística requer o desenvolvimento do pensamento estatístico, o qual permite que a pessoa seja capaz de utilizar ideias estatísticas e atribuir significado à informação estatística. Por outras palavras, ser capaz de fazer interpretações a partir de um conjunto de dados, de representações de dados ou de um resumo de dados (LOPES, 2004 apud LOPES; CARVALHO, 2009, p. 78).

O pensamento estatístico pode ser entendido como a capacidade de relacionar dados quantitativos com situações concretas, considerando sempre a presença da variabilidade e da incerteza, visando a explicitar o que os dados podem dizer sobre o problema em questão (MALLOWS, 1998 apud RIBEIRO, 2007).

Envolve, portanto, o desenvolvimento de hábitos mentais e habilidade de resolução de problemas. Dentre esses itens, Chance (2002 apud RIBEIRO, 2007) destaca:

$\rightarrow$ consideração sobre como melhor obter dados significativos e relevantes para responder à questão em estudo;

$\rightarrow$ reflexão constante sobre as variáveis envolvidas e curiosidade por outras maneiras de examinar os dados e o problema em questão;

$\rightarrow$ ver o processo por completo, com constante revisão de cada etapa;

$\rightarrow$ ceticismo onipresente sobre a obtenção dos dados;

$\rightarrow$ relacionamento constante entre os dados e o contexto do problema, bem como interpretação das conclusões em termos não-estatísticos;

$\rightarrow$ pensar além do livro-texto.

"Pode-se entender o pensamento estatístico como as estratégias mentais utilizadas pelo indivíduo para tomar decisão em toda a etapa de um ciclo investigativo" (SILVA, 2007, p. 30).

Já o raciocínio estatístico, pode ser definido como o modo de as pessoas raciocinarem com as ideias, conseguindo dar um significado à informação estatística. Em decorrência, ele envolve interpretações a partir de um conjunto, representação ou resumo de dados. Muitos dos raciocínios estatísticos combinam dados e acaso, originando a mobilização 
da capacidade de fazer interpretações estatísticas e inferências, simultaneamente (GARFIELD; GAL, 1999).

Segundo Costa e Capovilla (apud SILVA, 2007, p. 32), o raciocínio refere-se "aos processos pelos quais as pessoas avaliam e geram argumentos lógicos, aplicando o conhecimento na consecução de metas”. É, portanto, um processo interno e mental, no qual, por meio de argumentos construídos a partir da compreensão de determinada explicação ou da ação em meio a uma situação, procura-se compreender e realizar inferências de natureza probabilística.

De forma sintetizada, podemos pensar que o raciocínio estatístico representa a habilidade para trabalhar com as ferramentas e os conceitos aprendidos e que o pensamento estatístico conduz a uma compreensão global da dimensão do problema, permitindo ao aluno questionar espontaneamente a realidade observada por meio da Estatística (CHANCE, 2002 apud RIBEIRO, 2007).

Dessa forma,

O nível de letramento [literacia] estatístico é dependente do raciocínio e do pensamento estatísticos. Por outro lado, à medida que o nível de letramento estatístico aumenta, o raciocínio e o pensamento estatístico tornam-se mais apurados. [...] À medida que um indivíduo apresenta um raciocínio estatístico mais avançado, pode desenvolver também o pensamento estatístico. Do mesmo modo, desenvolvendo o pensamento estatístico pode elevar seu raciocínio estatístico a um nível mais elevado (SILVA, 2007, p. 35-36).

A partir desses princípios (e tomando-os por base), acreditamos que com uma Investigação Exploratória de Dados, na qual os alunos tenham a responsabilidade pela coleta dos dados brutos, organização, análise, interpretação e divulgação dos resultados, poderemos contribuir para o desenvolvimento dos hábitos e habilidades relacionados ao pensamento estatístico, proporcionando o trabalho efetivo e com significado sustentado pelas compreensões e argumentos decorrentes do raciocínio estatístico e, dessa maneira, desenvolveremos a literacia estatística de nossos alunos.

O GAISE apresenta alguns princípios para isso. 


\subsubsection{O Guidelines for Assessment and Instruction in Statistics Education (GAISE) Report:} a Pré-K-12 Curriculum Framework: fundamentos e princípios

O Guidelines for Assessment and Instruction in Statistics Education (GAISE) Report: a Pré-K-12 Curriculum Framework, aprovado pela American Statistical Association $(A S A)$, em agosto de 2005, representa um documento que fornece um quadro conceitual para a Educação Estatística a partir do documento Principles and Standards for School Mathematics (2000) do National Council of Teachers of Mathematics (NCTM), com o objetivo de complementá-lo e não substituí-lo.

Segundo o referido documento, os programas de ensino devem tornar os alunos capazes de:

\footnotetext{
$\rightarrow$ formular questões que possam ser dirigidas com dados e coleta, organização e apresentação de dados relevantes para respondê-las;

$\rightarrow$ selecionar e utilizar métodos estatísticos adequados para analisar os dados;

$\rightarrow$ desenvolver e avaliar inferências e previsões que são baseadas em dados; e

$\rightarrow$ compreender e aplicar conceitos básicos de probabilidade (ASA, 2005, p. 5, tradução nossa).
}

O GAISE apresenta a literacia estatística como objetivo principal da Educação Estatística, na medida em que nossas vidas são orientadas por números e informações que necessitam de um raciocínio estatístico adequado para lidar de forma inteligente com exigências relacionadas à cidadania, emprego e família, de forma a subsidiar uma vida saudável e produtiva (ASA, 2005).

No entanto, o documento destaca que de nada adianta os estudantes realizarem atividades relacionadas a esses objetivos se isto não for feito para solucionar problemas que tenham sido problematizados por eles. Da mesma forma, que o caminho para fazer inferências e tirar conclusões sobre os dados precisa ser determinado por eles (LOPES, 2008b, p. 68).

É necessário, portanto, problematizar situações significativas para os alunos, possibilitando a vivência da análise de dados.

O GAISE propõe que a resolução de problemas estatísticos identifica um processo que envolve quatro componentes:

I. Formulação de Questões

$\rightarrow$ Esclarecimento do problema em mãos

$\rightarrow$ Formulação de uma (ou mais) questão(ões) que possa(m) ser respondida(s) com os dados

II. Coleta de Dados

$\rightarrow$ Elaboração de um plano apropriado de coleta de dados 
$\rightarrow$ Utilização do plano para a coleta de dados

III. Análise dos Dados

$\rightarrow$ Escolha de métodos gráficos e numéricos apropriados

$\rightarrow$ Utilização desses métodos para analisar os dados

IV. Interpretação dos Resultados

$\rightarrow$ Interpretação das análises

$\rightarrow$ Relacionamento da interpretação com a questão inicial.

Nesse contexto, a estrutura conceitual para a Educação Estatística é fornecida por meio de um modelo bidimensional apresentado no Quadro 1.

Uma dimensão é definida pelos componentes do processo de resolução de problemas acrescido da natureza da variabilidade considerada e como focamos a variabilidade. A segunda dimensão é composta de três níveis de desenvolvimento. Cada uma das quatro primeiras linhas descreve um componente do processo que se desenvolve em todos os níveis. A quinta linha indica a natureza da variabilidade considerada em um nível determinado. Entende-se que o trabalho no Nível B assume e desenvolve ainda mais os conceitos do nível $\mathrm{A}$, e também o nível $\mathrm{C}$ assume e utiliza os conceitos a partir dos níveis mais baixos (ASA, 2005, p. 13, tradução nossa).

Dessa forma, o GAISE sugere o desenvolvimento conceitual em Estatística a partir do processo de resolução de problemas, porque deve levar em consideração o avanço nos níveis de desenvolvimento, por meio da conscientização quanto às ideias e aos conceitos envolvidos em uma investigação exploratória de dados. Semelhante desenvolvimento está intimamente relacionado à compreensão das naturezas da variabilidade presente no processo. Com a compreensão dos princípios estatísticos e de variabilidade, torna-se possível o desenvolvimento da postura crítica diante de informações que envolvam incerteza, estimativa e inferência, na direção de facilitar o desenvolvimento da Literacia Estatística. 
Quadro 1: O quadro modelo da estrutura conceitual em Educação Estatística.

\begin{tabular}{|c|c|c|c|}
\hline Componente do processo & Nível A & Nível B & Nível C \\
\hline I. Formulação da Questão & $\begin{array}{l}\text { Início da conscientização da } \\
\text { distinção de questões } \\
\text { estatísticas } \\
\text { Os professores propõem } \\
\text { questões de interesse } \\
\text { As questões são restritas à sala } \\
\text { de aula }\end{array}$ & $\begin{array}{l}\text { Uma maior sensibilização da } \\
\text { distinção de questões } \\
\text { estatísticas } \\
\text { Os alunos começam a levantar } \\
\text { as suas próprias questões de } \\
\text { interesse } \\
\text { As questões não são restritas à } \\
\text { sala de aula }\end{array}$ & $\begin{array}{l}\text { Os alunos podem fazer a } \\
\text { distinção de questões } \\
\text { estatísticas } \\
\text { Os alunos propõem suas } \\
\text { próprias questões de interesse } \\
\text { As questões procuram } \\
\text { generalizações }\end{array}$ \\
\hline II. Coleta de Dados & $\begin{array}{l}\text { Ainda não se concebe a } \\
\text { existência de diferenças } \\
\text { Censo de sala de aula } \\
\text { Experimentos simples }\end{array}$ & $\begin{array}{l}\text { Início da sensibilização para } \\
\text { concepção das diferenças } \\
\text { Investigações por amostragem; } \\
\text { começam a usar uma seleção } \\
\text { aleatória } \\
\text { Experimentos Comparativos; } \\
\text { começa a utilizar atribuição } \\
\text { aleatória }\end{array}$ & $\begin{array}{l}\text { Os alunos fazem concepção das } \\
\text { diferenças } \\
\text { Criações de amostragem com } \\
\text { uma seleção aleatória } \\
\text { Criação de Experimentos com } \\
\text { aleatoriedade }\end{array}$ \\
\hline III- Análise de Dados & $\begin{array}{l}\text { Utilizar propriedades } \\
\text { particulares de distribuições no } \\
\text { contexto de um exemplo } \\
\text { específico } \\
\text { Mostra variabilidade dentro de } \\
\text { um grupo } \\
\text { Compara indivíduo para } \\
\text { indivíduo } \\
\text { Compara indivíduos com o } \\
\text { grupo } \\
\text { Início da consciência de grupo } \\
\text { para grupo } \\
\text { Observa associação entre duas } \\
\text { variáveis }\end{array}$ & $\begin{array}{l}\text { Aprende a usar propriedades } \\
\text { particulares de distribuições } \\
\text { como ferramentas de análise } \\
\text { Quantifica variabilidade dentro } \\
\text { de um grupo } \\
\text { Compara grupo para grupo em } \\
\text { displays } \\
\text { Reconhece erro amostral } \\
\text { Algumas quantificações de } \\
\text { associação; modelos simples de } \\
\text { associação }\end{array}$ & $\begin{array}{l}\text { Entende e usa distribuições em } \\
\text { análise como um conceito } \\
\text { global } \\
\text { Mede a variabilidade dentro de } \\
\text { um grupo; mede a variabilidade } \\
\text { entre os grupos } \\
\text { Compara grupo para grupo } \\
\text { usando displays e medidas de } \\
\text { variabilidade } \\
\text { Descreve e quantifica erro } \\
\text { amostral } \\
\text { Quantificação da associação; } \\
\text { montagem dos modelos de } \\
\text { associação }\end{array}$ \\
\hline $\begin{array}{l}\text { IV. Interpretação dos } \\
\text { Resultados }\end{array}$ & $\begin{array}{l}\text { Os alunos não olham para além } \\
\text { dos dados } \\
\text { Não generalização para além da } \\
\text { sala de aula } \\
\text { Nota diferença entre dois } \\
\text { indivíduos com diferentes } \\
\text { condições } \\
\text { Observa associação em displays }\end{array}$ & $\begin{array}{l}\text { Os estudantes reconhecem que, } \\
\text { para além dos dados, é viável } \\
\text { Reconhecem que uma amostra } \\
\text { pode ou não ser representativa } \\
\text { da população maior } \\
\text { Observe a diferença entre os } \\
\text { dois grupos com diferentes } \\
\text { condições } \\
\text { É consciente da distinção entre } \\
\text { estudo observacional e } \\
\text { experimento } \\
\text { Nota diferenças na força de } \\
\text { associação } \\
\text { Básica interpretação de } \\
\text { modelos de associação } \\
\text { É consciente da distinção entre } \\
\text { associação de causa e efeito }\end{array}$ & $\begin{array}{l}\text { Os estudantes são capazes de } \\
\text { olhar para além dos dados em } \\
\text { alguns contextos } \\
\text { Generaliza a partir de amostra } \\
\text { de população } \\
\text { É consciente do efeito de } \\
\text { aleatoriedade sobre os } \\
\text { resultados dos experimentos } \\
\text { Entende a diferença entre } \\
\text { estudos observacionais e } \\
\text { experiências } \\
\text { Interpreta as medidas de força } \\
\text { de associação } \\
\text { Interpreta modelos de } \\
\text { associação } \\
\text { Distingue entre as conclusões } \\
\text { de estudos e experimentos de } \\
\text { associação }\end{array}$ \\
\hline Natureza da Variabilidade & $\begin{array}{l}\text { Variabilidade de Medição } \\
\text { Variabilidade natural } \\
\text { Variabilidade Induzida }\end{array}$ & Variabilidade de amostragem & Variabilidade ao acaso \\
\hline Foco da Variabilidade & $\begin{array}{l}\text { Variabilidade dentro de um } \\
\text { grupo }\end{array}$ & $\begin{array}{l}\text { Variabilidade dentro de um } \\
\text { grupo e variabilidade entre os } \\
\text { grupos } \\
\text { Covariabilidade }\end{array}$ & $\begin{array}{l}\text { Variabilidade no modelo } \\
\text { apropriado }\end{array}$ \\
\hline
\end{tabular}

Fonte: ASA (2005, p. 14-15, tradução nossa) 


\subsubsection{Construção, Leitura e Interpretação de Gráficos}

Quando pensamos em literacia estatística, principal objetivo do ensino de Estatística segundo o GAISE, fatalmente deparamo-nos com o aspecto relacionado à representação de dados. Cabe esclarecer que, neste trabalho, entendemos por representação de dados a capacidade de organização, leitura e interpretação de informações expressas em gráficos e tabelas. Segundo Wainer (1992), o uso de gráficos está tão internalizado que não é possível imaginar o mundo sem ele.

A temática é bastante relevante no contexto educacional, na medida em que o Indicador Nacional de Alfabetismo Funcional (INAF) - 2002 aponta para a pouca familiaridade da população brasileira com a leitura e interpretação de gráficos e tabelas. Segundo o relatório do $2^{\circ}$. INAF realizado no ano de 2002 , apenas $21 \%$ da população brasileira demonstra certa familiaridade com representações gráficas como mapas, tabelas e gráficos (IPM, 2002). O $4^{\circ} \mathrm{INAF}$, realizado no ano de 2004, evidenciou que esse índice teve um discreto crescimento atingindo os 23\% (IPM, 2004). Releva-se, portanto, a urgente necessidade de a Escola Fundamental iniciar o trabalho com as representações tabelares e gráficas como estratégia de democratização do acesso à informação e a recursos e procedimentos para organizá-la e analisá-la. A deficiência dessa habilidade tem sido motivo de grandes preocupações dos educadores, gerando novas pesquisas com relação ao pensamento estatístico.

Nesse contexto, Lopes (2004) salienta a necessidade de se aprofundar a reflexão quanto à formação estatística que se tem oferecido a nossa população. Semelhante limitação também pode ser constatada quando analisamos os desempenhos de nossos alunos nas avaliações realizadas nos últimos anos ${ }^{12}$.

No entanto, há que se destacar, também, que muitos dos trabalhos desenvolvidos na área de Educação Estatística tratam apenas da leitura e interpretação de gráficos. Em sua maioria, constatam muitas dificuldades, mas não tratam do aspecto relacionado à construção dessas representações. Analisar apenas a capacidade de leitura e interpretação significa priorizar o resultado em detrimento do processo. É importante analisála como decorrente de um processo maior que envolve a reflexão sobre todas as etapas de uma investigação estatística. Um trabalho que trate de todos esses aspectos pode facilitar a

\footnotetext{
${ }^{12}$ Faremos uma discussão mais aprofundada no terceiro capítulo.
} 
capacidade de leitura e interpretação de gráficos e tabelas, bem como possibilitar a compreensão plena das informações estatísticas.

Wainer (1992) tece uma crítica bastante pertinente quanto à priorização da leitura e interpretação de gráficos nas pesquisas que vêm sendo realizadas, na medida em que muitas das dificuldades e equívocos relacionados com essas habilidades podem decorrer de uma construção defeituosa e/ou falha. Segundo o autor, caracterizar a capacidade de compreensão de informações apresentadas em um gráfico defeituoso é semelhante a caracterizar a capacidade de alguém ler por meio de questões repletas de erros ortográficos. Afinal, ele indaga: “O que estamos testando realmente?” (WAINER, 1992, p. 16).

Embora haja evidências de que a capacidade de compreender gráficos apresenta dificuldades, não há evidências de que aquela para desenhar gráficos também não apresente problemas. Assim, devemos tratar da capacidade de construção. Além de tornar os alunos capazes de organizar seus dados por meio de registros gráficos e tabelares, com a elaboração de gráficos eles podem tomar consciência das relações existentes explicita e implicitamente em cada representação de forma a perceber erros em outras construções, contribuindo para o desenvolvimento da literacia plena e efetiva.

Alguns pesquisadores desenvolveram estudos no sentido de estabelecer níveis para este "letramento" estatístico. No presente trabalho, apoiamo-nos em Shamos (1995 apud GAL, 2002), que propõe um modelo composto de três níveis:

- nível cultural: relacionado aos indivíduos que compreendem termos básicos utilizados no cotidiano;

- nível funcional: relacionado aos indivíduos que desenvolvem a capacidade de ler e escrever, de forma coerente, informações estatísticas;

- nível científico: relacionado aos indivíduos que desenvolvem a capacidade de lidar com conhecimentos científicos de esquemas conceituais mobilizados durante a realização de situações-problema.

Apenas no nível científico é que o indivíduo apresenta autonomia e segurança em suas escolhas. Dessa forma, se o professor estiver em um nível inferior, certamente comprometerá a aprendizagem dos alunos que, por conseguinte, terão dificuldades em lidar com as informações estatísticas, permanecendo nos níveis mais básicos de letramento, não atingindo o nível científico. 


\subsubsection{Gráficos: fundamentos para leitura e interpretação}

O domínio da linguagem gráfica funciona como pré-requisito para a superação da dicotomia entre construção e interpretação.

O domínio da linguagem gráfica refere-se à capacidade de leitura dos dados presentes em um gráfico, permitindo que a pessoa leitora consiga interpretar os dados e generalizar a informação nele presente. Dessa forma, existe uma evolução para a compreensão das pessoas sobre diferentes formas de representação (CURCIO, 1987 apud LOPES, 2004, p. 190).

Para balizar nossas análises e interpretações concernentes a esse tipo de linguagem, pautamo-nos em Curcio (1987), que estabelece três níveis de compreensão de informações expressas em gráficos, a saber:

- "Ler os dados": esse nível de compreensão requer uma leitura literal do gráfico, porque não se realiza a interpretação da informação contida na representação. A pessoa retira os fatos explícitos, lendo apenas informações apresentadas nos eixos e nas legendas, sem realizar qualquer tipo de interpretação, respondendo apenas às questões imediatas (CURCIO, 1989 apud LOPES, 2004).

- "Ler entre os dados": inclui não só interpretação e integração dos dados do gráfico, como também requer habilidade para comparar quantidades e usos de conceitos e destrezas matemáticas. A pessoa realiza alguma interpretação dos dados e da forma como eles estão integrados no gráfico, ao mesmo tempo, em que recorre a outros conceitos e capacidades, o que lhe permite identificar relações matemáticas visíveis no gráfico. Nesse nível, a pessoa começa a realizar inferências de natureza simples (CURCIO, 1989 apud LOPES, 2004).

- "Ler além dos dados": requer que o leitor realize previsões e inferências, a partir dos dados sobre informações que não estejam refletidas diretamente no gráfico. A pessoa é capaz de inferir ou predizer um determinado resultado ou acontecimento em função de vários outros e não apenas de alguma informação apresentada no gráfico. Ao atingir esse patamar, ela adquire condição de responder a perguntas implícitas tendo como base extrapolações, previsões ou inferências realizadas a partir de uma interpretação (CURCIO, 1989 apud LOPES, 2004).

Estabelecendo uma analogia entre os níveis propostos por Curcio e os de Alfabetismo Funcional do INAF, podemos dizer que: 
$\rightarrow$ O nível 1 do Alfabetismo Funcional em Matemática permite ao sujeito ler números de uso frequente em contextos específicos. Assim, o aluno poderá realizar a leitura dos dados, retirando deles os fatos explícitos.

$\rightarrow$ No nível 2 do Alfabetismo Funcional em Matemática, o sujeito já demonstra dominar completamente a leitura dos números naturais e é capaz de ler e comparar números decimais. Assim, o sujeito já poderá realizar alguma leitura entre os dados, com sua interpretação e de suas relações, inclusive com inferências simples.

$\rightarrow$ No nível 3 do Alfabetismo Funcional em Matemática, o sujeito demonstra certa familiaridade com representações gráficas (mapas, tabelas e gráficos). Portanto, possivelmente, ele poderá realizar a leitura além dos dados, utilizando os números e as estruturas de representação para inferir e/ou predizer algum resultado em função de outros. Consegue responder a questões implícitas com base em extrapolações, previsões e inferências realizadas a partir de uma interpretação.

Nesse contexto, da comparação dos dados apresentados pelos INAFs 2002 e 2004, sob a ótica dos níveis de Curcio, emerge a necessidade de se (re)pensar o processo de ensino e aprendizagem estatística, de modo a preparar os alunos para uma prática competente.

Apesar de os gráficos serem a forma mais utilizada para apresentação de dados e resumos estatísticos, existem outras maneiras de registro que também são úteis para apresentação de dados. Uma delas é a tabela, que é discutida a seguir.

\subsubsection{Tabelas: estrutura, leitura e interpretação}

Tabela é um conjunto de dados dispostos em linhas e colunas distribuídos ordenadamente, em função de alguns critérios adotados pelos diversos sistemas estatísticos e de acordo com os interesses em questão. 
De uma maneira mais sistematizada, uma tabela é composta de:

a) Corpo - conjunto de linhas e colunas que contém informações sobre a variável em estudo;

b) Cabeçalho - parte superior da tabela que especifica o conteúdo das colunas;

c) Coluna indicadora - parte da tabela que especifica o conteúdo das linhas;

d) Linhas - retas imaginárias que facilitam a leitura, no sentido horizontal de dados que se inscrevem em seus cruzamentos com as colunas;

e) Casa ou célula - espaço destinado a um só número;

f) Título - conjunto de informações, as mais completas possíveis, respondendo às perguntas: O quê? Quando? Onde? Localizadas no topo da tabela (CRESPO, 1999, p.25).

As tabelas podem ser simples ou de dupla entrada. A primeira organiza dados, estabelecendo as relações entre eles e uma característica, enquanto a segunda organiza dados que possuem mais de uma característica, representando, portanto, duas ordens de classificação: uma horizontal (linha) e outra vertical (coluna).

Flores e Moretti (2005) afirmam que a tabela demonstra uma organização semiótica $^{13}$ e que sua organização depende da maneira como os dados estão dispostos e se relacionam. Conforme afirma Duval, as tabelas podem ser classificadas em dois tipos, em termos de análise semiótica.

- Tabelas que se constituem apenas como uma apresentação sinóptica, como um
"banco de dados", servindo apenas para uma consulta rápida o que implica num
custo cognitivo bastante baixo. A leitura deste tipo de tabela é dada a partir de uma
exploração vertical, ou horizontal, de uma ponta a outra, com parada sobre a casa
correspondente ao dado indicado na questão que motiva a exploração.
- Tabelas que permitem aparecer novos dados, inferir a existência de relações ou de
elementos não ainda conhecidos, ou ainda mostrar a necessidade de distinções que
até então não tinham sido levados em conta. A leitura deste tipo de tabela implica
numa dupla exploração, vertical e horizontal e, além disso, essa exploração deve ser
simultânea (2002 apud FLORES; MORETTI, 2005, p. 8-9).

Segundo Wainer (1995 apud RIBEIRO, 2007), o primeiro tipo de tabela esclarece questões de nível elementar, visto que envolve apenas a extração de dados. Já o segundo, exige dois níveis de compreensão: o intermediário e o avançado.

$\mathrm{O}$ nível intermediário engloba questões de interpolação e descoberta das relações existentes entre os dados apresentados na tabela. O nível avançado, por sua vez, reclama uma compreensão mais ampla da estrutura dos dados apresentados, enquanto contempla sua totalidade, normalmente, bem como compara tendências e analisa relações implícitas.

\footnotetext{
${ }^{13}$ A Teoria de Registro de Representação Semiótica de Raymond Duval será tratada a seguir.
} 


\subsection{A Teoria de Registros de Representação Semiótica}

Ao se pensar no trabalho com gráficos e tabelas no Ensino Fundamental (EF), é necessário considerar que a Matemática trata de objetos simbólicos não físicos, a começar pelos números, não diretamente perceptíveis ou observáveis com ajuda de instrumento. Assim, para a compreensão e apreensão do objeto matemático, é fundamental não confundi-lo com sua representação. Neste contexto de pesquisa e análise, valemo-nos da Teoria de Registros de Representação Semiótica de Duval para orientar nossas atividades, na medida em que acreditamos que o funcionamento cognitivo no processo de aprendizagem matemática é inseparável da existência da diversidade de registros.

Para Duval, ela demonstra-se essencial para a aprendizagem matemática que, para ocorrer necessita que o indivíduo utilize diferentes registros para representar um mesmo objeto. A conceituação só será alcançada, quando for possível articular os diferentes registros de representação de um determinado objeto, coordenando a semiósis - produção de uma representação semiótica - e a noésis - apreensão conceitual de um objeto.

Duval salienta que existem quatro tipos muito diferentes de registro:

Quadro 2: Classificação dos diferentes registros mobilizados no funcionamento matemático (fazer matemático, atividade matemática).

\begin{tabular}{|c|c|c|}
\hline & REPRESENTAÇÃO DISCURSIVA & REPRESENTAÇÃO NÃO-DISCURSIVA \\
\hline $\begin{array}{l}\text { REGISTROS MULTIFUNCIONAIS } \\
\text { Os tratamentos não são algoritimizáveis }\end{array}$ & 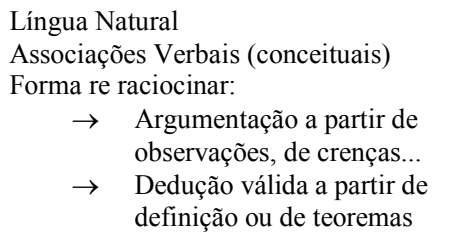 & $\begin{array}{l}\text { Figuras geométricas planas ou em perspectiva } \\
\text { (configurações em dimensão } 0,1,2 \text { ou } 3 \text { ) } \\
\quad \rightarrow \quad \text { Apreensão operatória e não } \\
\quad \text { somente perceptiva } \\
\quad \rightarrow \quad \text { Construção com instrumentos }\end{array}$ \\
\hline $\begin{array}{l}\text { REGISTROS MONOFUNCIONAIS } \\
\text { Os tratamentos são principalmente } \\
\text { algoritmos }\end{array}$ & 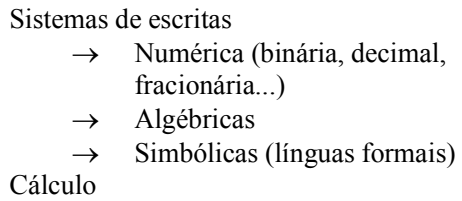 & $\begin{array}{l}\text { Gráficos Cartesianos } \\
\qquad \begin{aligned} & \text { Mudança de sistema de } \\
& \text { coordenadas } \\
\rightarrow & \text { Interpolação, extrapolação }\end{aligned}\end{array}$ \\
\hline
\end{tabular}

Fonte: DUVAL (2003, p. 14)

Portanto, para Duval (1990 apud FLORES; MORETTI, 2005), os diferentes registros de representação semiótica podem ser definidos em função dos conhecimentos em jogo na sua utilização. 
Os Registros de Representação Discursiva Multifuncional são adequados para as definições em língua natural, enquanto que os Registros de Representação Discursiva Monofuncional fazem apelo à linguagem matemática, o que exige que se disponha de conhecimentos associados a outras noções como, por exemplo, o conceito e a representação de porcentagem e ângulo na compreensão de um gráfico de setores.

Os Registros de Representação Não-Discursiva Multifuncional são utilizados no momento que se pretende ou se necessita de uma representação geométrica, uma figura plana ou espacial, ou uma representação de símbolos pré-definidos que podem ser operados (por exemplo, as tabelas e os gráficos de setores), enquanto que os Registros de Representação Não-Discursiva Monofuncional recorrem aos gráficos cartesianos (gráficos de barras, colunas e histogramas).

Para que haja coordenação entre os signos e seus conceitos, é preciso que haja a mobilização simultânea de, ao menos, dois registros de representação ou que haja, a todo momento, troca de registro de representação.

Existem dois tipos de transformações de representação semiótica, radicalmente distintos: os tratamentos e as conversões.

Os tratamentos são transformações de representação dentro de um mesmo registro: por exemplo, efetuar um cálculo ficando estritamente no mesmo sistema de escrita ou de representação dos números; resolver uma equação ou um sistema de equações; completar uma figura segundo critérios de conexidade e simetria.

As conversões são transformações de representações que consistem em mudar de registro conservando os mesmos objetos denotados: por exemplo, passar da escrita algébrica de uma equação à sua representação gráfica (DUVAL, 2003, p. 16).

Quando um aluno realiza a passagem entre diferentes registros, ele toma consciência do objeto em questão. Assim, do ponto de vista matemático, a conversão intervém apenas na escolha do registro, não tendo nenhum papel intrínseco. No entanto, do ponto de vista cognitivo, é a conversão que aparece como atividade de transformação representacional fundamental que conduz aos mecanismos subjacentes à compreensão. Essa diferença, muitas vezes, não é considerada nas pesquisas em didática e ensino de matemática (DUVAL, 2003).

Nesse contexto, Duval salienta a necessidade de se levar em conta o ponto de vista cognitivo nas análises de aprendizagem e nos processos de compreensão, levantando as duas justificativas apresentadas a seguir.

A conversão das representações é irredutível a um tratamento: não podemos considerar a conversão de um objeto de um registro a outro uma operação simples, ou uma associação preestabelecida entre nomes e figuras, reduzindo-a a uma codificação. 
Uma tal visão é superficial e enganadora não somente nos fatos concernentes às aprendizagens, mas igualmente de um ponto de vista teórico, pois a regra de codificação permite somente uma leitura pontual das representações gráficas [por exemplo]. Essa regra não permite uma apreensão global e qualitativa (DUVAL, 2003, p. 17).

Um segundo fator de relevância ao aspecto cognitivo são os fenômenos observáveis em qualquer operação de conversão: a) as variações de congruência e nãocongruência; b) a heterogeneidade dos dois sentidos de conversão.

Partindo do princípio de que para analisar uma atividade de conversão é suficiente comparar a representação no registro de partida com a representação terminal no registro de chegada, temos duas situações a serem consideradas. Se a representação terminal transparece na representação de saída e a conversão se aproxima de uma codificação, diz-se então que há uma congruência. Não havendo essa relação direta, ocorre a não congruência.

Além dessas relações, há que se considerar a importância do sentido da conversão, tendo em vista que nem sempre a conversão se efetua, quando se invertem os registros de partida e de chegada.

Geralmente, no ensino, um sentido de conversão é privilegiado, pela idéia de que o treinamento efetuado num sentido estaria automaticamente treinando a conversão no outro sentido. Os exemplos propostos aos alunos são instintivamente escolhidos, evidentemente, nos casos de congruência. Infelizmente esses não são os casos mais frequentes (DUVAL, 2003, p. 20).

Diante das considerações acerca do processo de registros de representação semiótica acima tratadas, deparamo-nos com o que Duval denomina paradoxo da compreensão em Matemática: como podemos não confundir um objeto e sua representação, se não temos acesso a esse objeto a não ser por meio de sua representação?

O ponto decisivo para entender esse questionamento está no fato de que o conteúdo matemático de uma representação depende mais do registro de representação do que do objeto representado. Mudar de um registro a outro perpassa pela explicitação/explicação de suas propriedades ou dos aspectos diferentes de um mesmo objeto (DUVAL, 2003).

As únicas variações de representação que são cognitivamente importantes no registro de partida são aquelas que provocam uma modificação da representação concomitante no registro de chegada, porque isso implica um novo objeto denotado (DUVAL, 2003, p. 26).

Cabe salientar que o interesse pelo mundo das representações semióticas não decorre, tão somente, da possibilidade de entendimento cognitivo acerca da aprendizagem matemática, "mas pelas funções cognitivas que estas representações preenchem e que, portanto, auxiliam no processo da educação matemática” (FLORES; MORETTI, 2005, p. 03). 
Segundo Duval (1999 apud op. cit.), são quatro as funções que as representações podem preencher:

$\rightarrow$ Comunicação: função de transmissão das mensagens entre os indivíduos, a qual requer a utilização de um código comum.

$\rightarrow$ Tratamento: função responsável pela transformação de uma representação em outra, utilizando o sistema de representação mobilizado.

$\rightarrow$ Objetivação: permite que um sujeito tome consciência daquilo que até então não tinha feito. É a exteriorização, dando lugar a uma produção de modo vocal ou gráfico, sendo às vezes confundida com a de comunicação. O que a difere é que, de uma certa maneira, ela corresponde a um uso estritamente privado de um registro de representação, mesmo se a produção for acessível a outra.

$\rightarrow$ Identificação: permite (re)encontrar uma informação entre muitas. Tratase do trabalho cognitivo que permite a recuperação da memória.

Duval avalia que as três primeiras funções são fundamentais para 0 funcionamento cognitivo. No entanto, a quarta função desempenha importância substancial no contexto deste trabalho, à medida em que é solicitada para ler e analisar uma tabela de dados.

Não obstante, ressaltamos o fato de que o trabalho com representações gráficas preenche as quatro funções cognitivas do pensamento. A identificação é fundamental para o tratamento das representações. No âmbito da comunicação, basta abrirmos um jornal qualquer para percebermos essa importância. Quando pensamos na inserção, no cotidiano do aluno, de representações gráficas tais como quadros, tabelas, gráficos cartesianos, gráficos de barras, gráficos com três dimensões e diagramas circulares, elas preenchem, não só o papel de comunicação, como é o caso principalmente dos jornais, mas de objetivação e tratamento.

Para o aluno, não é suficiente que ele saiba "ler" um gráfico, é necessário também
que ele saiba organizar e operar de forma objetiva sobre os dados contidos neste
modo de representação. Assim sendo, consideramos necessária uma análise do
funcionamento tanto cognitivo como semiótico nas representações gráficas na
educação matemática (FLORES; MORETTI, 2005, p. 4).

Finalmente, há que se salientar a diferença entre uma representação gráfica e uma tabela. Apesar de esta ser considerada uma construção mais simples, na medida em que é estruturada em linhas e colunas, a "simplicidade" é apenas visual. Enquanto os gráficos cartesianos são representações que possibilitam o aparecimento de formas visuais, tais como retas, curvas e contornos de superfícies, as tabelas não apresentam esse recurso, impossibilitando o agrupamento dos dados de modo a facilitar o delineamento de uma forma gráfica. "Dispor os dados em linhas e em colunas não faz, portanto, aparecer nenhuma forma 
visível interpretável como em um diagrama ou numa imagem" (DUVAL, 2002 apud FLORES; MORETTI, 2005, p. 6-7).

Ainda que a frequente utilização da tabela volte-se a uma identificação pontual (como no caso de se investigar qual a característica mais presente em um determinado grupo a partir de uma tabela de frequências), existem situações nas quais se reclama a leitura global da tabela, por exemplo, ao se analisar a variação da temperatura numa tabela de distribuição das temperaturas médias num determinado período. "A passagem de um passo pontual para um passo de interpretação global na 'leitura' das tabelas representa um salto do ponto de vista cognitivo" (ibidem, p. 8).

Logo, não se pode negar a funcional contribuição da Teoria de Registros de Representação Semiótica para a Educação Estatística, em razão da compreensão dos aspectos cognitivos envolvidos no processo. No entanto, em qualquer situação que envolva ensino e aprendizagem, as concepções teórico-metodológicas necessitam estar claras e bem constituídas para subsidiar as atividades realizadas em sala de aula e nortear as posturas e responsabilidades de cada um dos agentes envolvidos. Nessa direção, cabe-nos discutir a Teoria das Situações Didáticas de Brousseau.

\subsection{A Teoria das Situações Didáticas}

A Teoria das Situações Didáticas desenvolvida por Guy Brousseau busca criar um modelo de interação entre o aprendiz, o saber e o milieu, no intuito de modelar o processo de ensino e aprendizagem dos conceitos matemáticos. Cabe salientar que o uso do termo milieu (ou milieux, em francês) será preservado neste trabalho e não substituído por sua tradução em português "meio", tendo em vista que, conforme evidenciaremos no decorrer do trabalho, a adoção desse termo não ajusta à explicitação de nossa concepção.

Para Brousseau,

Um processo de aprendizagem pode ser caracterizado de modo geral (se não determinado) por um conjunto de situações identificáveis (naturais ou didáticas) reprodutíveis, conduzindo frequentemente à modificação de um conjunto de comportamentos de alunos, modificação característica da aquisição de um determinado conjunto de conhecimentos (BROUSSEAU, 1975 apud ALMOULOUD, 2007, p. 31).

O objetivo central dessa teoria não é o sujeito cognitivo, mas as interações estabelecidas entre professor, aluno e saber no contexto de uma situação didática. Ela apóia-se em três hipóteses: 
1. A aprendizagem ocorre quando o aluno consegue se adaptar ao milieu que é fator de dificuldades, contradições e desequilíbrio, sendo a prova da aprendizagem as novas respostas desses alunos. Trata-se de uma referência à epistemologia construtivista de Piaget, em que a aprendizagem decorre dos processos de adaptações.

2. O professor necessita criar um milieu munido de intenções didáticas, tendo em vista que a inexistência dessa intencionalidade dificulta a aquisição de conhecimento.

3. O milieu e as situações desenvolvidas "devem engajar fortemente os saberes matemáticos envolvidos no processo de ensino e aprendizagem" (ALMOLOUD, 2007, p. 33).

Partindo da ideia de que uma situação de comunicação envolve não só uma pessoa, mas também as circunstâncias em que ela se encontra e as relações que a unem a esse milieu, Brousseau define as situações didáticas como "situações que servem para ensinar" (BROUSSEAU, 1997, p. 2). Uma situação modela as relações e as interações de um ou mais agentes com um meio. O agente, para o autor, é aquele que age sobre o meio de modo racional e econômico de acordo com as regras da situação (BROUSSEAU, 1997). No caso, tanto pode ser o professor, quando organiza a situação para ensinar, quanto o aluno, que age sobre o meio e, agindo, aprende.

O objetivo central da teoria, portanto, é a situação didática, definida de maneira mais sistematizada como:

O conjunto de relações estabelecidas explicitamente e/ou implicitamente entre um aluno ou um grupo de alunos, um certo milieu (contendo eventualmente instrumentos ou objetos) e um sistema educativo (o professor) para que esses alunos adquiram um saber constituído ou em constituição (BROUSSEAU, 1978 apud ALMOLOUD, 2007, p. 33).

Brousseau também salienta a importância da situação adidática no contexto daquela, já que se trata de uma situação, em cujo âmbito a intenção de ensinar não é revelada ao aprendiz, mas foi concebida pelo professor objetivando criar-lhe condições favoráveis para a apropriação do novo saber (op. cit.). Assim, uma situação adidática apresenta as seguintes características: 
- O problema matemático é escolhido de modo que possa fazer o aluno agir, falar, refletir e evoluir por iniciativa própria;

- O problema é escolhido para que o aluno adquira novos conhecimentos que sejam inteiramente justificados pela lógica interna da situação e que possam ser construídos sem apelos às razões didáticas ${ }^{14}$;

- O professor, assumindo o papel de mediador, cria condições para o aluno ser o principal ator da construção de seus conhecimentos a partir da(s) atividade(s) proposta(s) (BROUSSEAU, 1986 apud ALMOLOUD, 2007, p. 33).

Cabe-nos esclarecer que a classificação das situações em didática e adidática não traz juízo de valor. Pode-se dizer que ambas as situações são importantes, já que têm funções diferentes. A alternância entre elas pode ajudar a atingir um número maior de alunos de uma classe, uma vez que não se consegue envolver todos o tempo todo num único tipo de atividade.

Os processos de ensino e aprendizagem estão apoiados na devolução, “definida como o ato pelo qual o professor faz o aluno aceitar a responsabilidade de uma situação ou de um problema" (ALMOLOUD, 2007, p. 35). Em um ensino que visa à construção do conhecimento, o professor quer conseguir a devolutiva, ou seja, que, pelo menos boa parte dos alunos, aceite o problema como próprio e passe a buscar a solução mais adequada. Quando o professor aplica as atividades em sala de aula e o saber a ensinar se torna saber ensinado, a realidade de cada sala de aula, do grupo de alunos, de seu envolvimento, constitui um meio complexo em que as relações professor-saber-aluno se estabelecem. Cabe ao professor gerenciar tais situações.

Nesse contexto, evidencia-se a necessidade de um milieu antagonista, capaz de produzir retroações sobre os conhecimentos do sujeito, por meio da resistência sobre suas ações, forçando-o a evoluir em suas estratégias (ALMOLOUD, 2007). Em outras palavras, é necessário que o aluno seja desafiado pelo milieu para que ele possa se empenhar na resolução de um problema e efetivamente aprender. Trata-se da superação do sistema instrucionista de ensino, no qual o professor apresenta a situação-problema e, em seguida, explica/estabelece o método de resolução, eliminando completamente o milieu antagonista. Segundo a teoria das Situações Didáticas, nesse tipo de situação o aluno pode não aprender, haja vista que não existem desafios e a situação não foi vivenciada, tampouco interiorizada.

Para analisar o processo de aprendizagem, a teoria das situações considera quatro tipos de dialéticas ou interações fundamentais:

- Dialética de ação: consiste na proposição de um problema para o aluno, o qual clame pelo conhecimento a ensinar para sua solução. A partir da provocação inicial, o

\footnotetext{
${ }^{14} \mathrm{O}$ aluno aprende por uma necessidade própria e não por uma necessidade aparente do professor ou da escola.
} 
aluno passa a agir sobre o problema, julgando o resultado de suas ações e o ajusta, quando necessário, sem a intervenção do professor. Trata-se de possibilitar a retroação dos conhecimentos do sujeito sobre o milieu. É a fase de manipulação de materiais e saberes, de reconhecimentos e construção de estratégias.

- Dialética de formulação: consiste em proporcionar ao aluno condições para a construção progressiva de uma linguagem compreensível por todos, possibilitando a troca de informações. É a busca de informações e a troca de saberes e mensagens com os demais componentes do milieu, visando a adquirir novos conhecimentos e a formular um modelo explícito para a solução do problema em questão. Para tanto, o trabalho em grupo favorece o desenvolvimento do raciocínio dos alunos, à medida que possibilita a troca de informações, contraposição de ideias e explicitação verbal de suas formulações, buscando validar suas ideias e explicitar os equívocos e erros das demais a serem refutadas.

- Dialética de validação: é a etapa em que o aprendiz deve evidenciar a validade do modelo criado, por meio da coordenação da semiósis e da noésis (se possível). É o momento em que cada aluno tenta validar seu modelo apresentando as evidências e o raciocínio sob o qual foi constituído, enquanto os demais podem solicitar maiores esclarecimentos e informações e/ou apresentar contraprovas que invalidem o modelo proposto. Dessa forma, a teoria funciona como milieu para o estabelecimento de provas ou para refutá-las (ALMOLOUD, 2007).

- Dialética de institucionalização: consiste na fixação de forma convencional e explícita do novo saber pelo professor. A partir da institucionalização, esse saber se torna oficial e deve ser incorporado aos esquemas mentais dos alunos, possibilitando sua utilização na resolução de problemas matemáticos. Após ouvir e discutir as soluções dos alunos, o professor deve explicitar o novo conceito matemático e formalizar o novo assunto. $\mathrm{Na}$ institucionalização, o saber é descontextualizado de forma a tornar possível sua aplicação/contextualização em outras situações.

É notório que, em todas as etapas da situação, o milieu desempenha um papel fundamental quanto à efetividade e qualidade da atividade proposta. Assim, cabe uma discussão mais aprofundada acerca de sua estrutura, conforme faremos a seguir. 


\subsubsection{A Estrutura do milieu}

Um dos pontos fundamentais da Teoria das Situações é a noção de milieu, introduzida para analisar as relações entre os alunos, os conhecimentos e as situações. Assim, torna-se imprescindível uma reflexão mais aprofundada de forma a identificar e estabelecer as posições dos "agentes" em cada uma das situações. Para tanto, baseamo-nos no esquema de análise descendente da atividade do professor, nos diversos níveis de estruturação do milieu, até a devolutiva para o aluno que inicia uma análise ascendente, partindo de uma situação aditática, até atingir a situação didática (Figura 1).

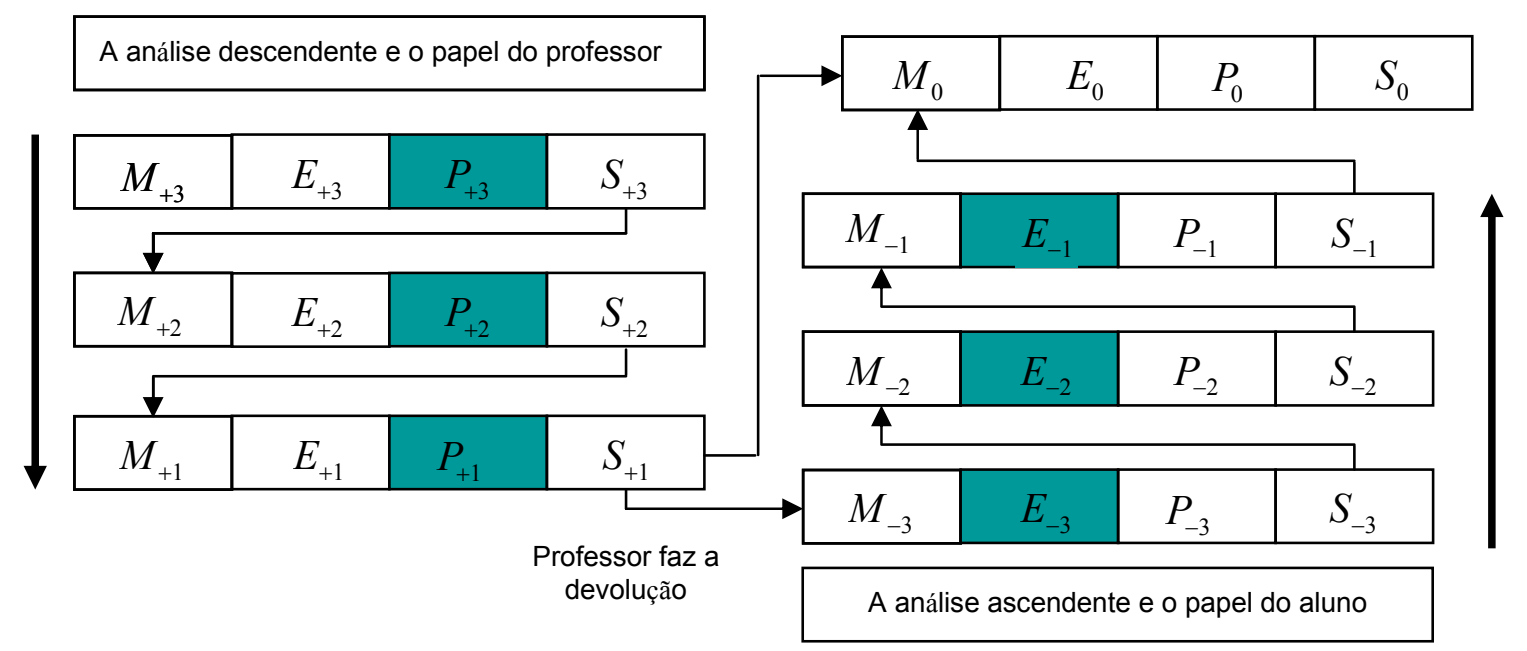

Figura 1: Estrutura do milieu (ALMOLOUD, 2007, p. 44)

$\mathrm{Na}$ estrutura acima, $\boldsymbol{M}$ indica o milieu; $\boldsymbol{E}$, o aluno; $\boldsymbol{P}$, o professor e $\boldsymbol{S}$, a situação. De acordo com essa estrutura, no nível +3 (noosfera), o professor reflete sobre o ensino de determinado tema. Ao alcançar o nível +2 (construção), inicia o delineamento de grandes linhas em busca de uma situação fundamental. No nível +1 , ele realiza o planejamento de sua aula (projeto). Assim, atinge o nível 0 (nível didático) que caracteriza a ação do professor na sala de aula.

É o nível da institucionalização. A situação $S_{0}$ é formada pelas interações $M_{0}, E_{0}, P_{0}$. O milieu $M_{0}$ é constituído pelas interações entre um milieu $\left(M_{-1}\right)$, um sujeito que caracteriza uma das posições do aluno $\left(E_{-1}\right)$ e um sujeito que caracteriza uma das posições do professor $\left(P_{-1}\right)$ (ALMOLOUD, 2007, p. 44).

No âmbito discente, o nível -3 refere-se ao momento em que o professor faz a devolutiva do problema e o aluno toma conhecimento dela. O nível -2 é a situação de referência, na qual os alunos estão resolvendo um problema e o professor atua como 
mediador, realizando as intervenções julgadas necessárias. No nível -1 (observação) ocorre a devolução dos alunos, quando se identifica a situação de aprendizagem.

Neste contexto, ao pensar uma sequência de atividades a partir de uma investigação exploratória de dados, iniciamos o trabalho sobre a estrutura do milieu, à medida que refletimos quais os melhores caminhos a serem tomados para o desenvolvimento das habilidades de coleta, organização, leitura e interpretação de dados, bem como dos conceitos matemáticos envolvidos no processo. Ao estruturarmos a sequência, perpassamos pelo nível de construção delineando todas as suas etapas. Ao efetivarmos as atividades, em sala de aula, atingimos o nível didático, no qual o aluno deve atuar no desenvolvimento de todas as atividades e o professor assume a função de mediador no desenvolvimento delas, intervindo nos momentos que julgar necessário, sempre pautado pela estrutura do milieu antagônico. Concomitantemente, o aluno inicia seu trabalho a partir das provocações e situações propostas pelo professor, visando a criar uma situação-problema real e de interesse do aluno, de forma a atribuir sentido à investigação e evidenciar a necessidade de realização desse tipo de procedimento. Criada a situação, os alunos, mediados pelo professor, passam a estabelecer procedimentos para a coleta de dados já pensando no processo de organização posterior, tendo em vista que a qualidade dos resultados de uma investigação está diretamente relacionada ao tipo de procedimento utilizado para a coleta de dados. Finalmente, atingimos o nível de observação, quando os alunos devem fazer a devolutiva do problema com a apresentação dos resultados. Nesta situação, trata-se da apresentação das análises e interpretações dos gráficos e tabelas construídos com os dados coletados, com o objetivo de responder ao questionamento inicial.

Assim, acreditamos que a Teoria das Situações traz significativas contribuições para a concepção e desenvolvimento de uma sequência didática, na medida em que norteia nosso olhar e, em conjunto com a Teoria de Registros de Representação Semiótica, fundamenta as ações e análises da pesquisa. Por outro lado, o estabelecimento de uma ordenação e articulação das atividades (didáticas e adidáticas) pode facilitar o planejamento da ação educacional e orientar as posturas e atuações de cada um dos agentes envolvidos, de modo a atingir o objetivo educacional esperado (a aprendizagem). É com esse propósito que apresentaremos os fundamentos teóricos que sustentam nossa concepção de sequência didática. 


\subsubsection{Sequência Didática}

O conceito de sequência didática é aqui entendido sob a concepção de Zabala (1998), para quem a ordenação articulada das atividades pode ser o elemento diferenciador das metodologias, sendo o primeiro aspecto característico de um método de ensino, o tipo de ordem em que se propõem as atividades. Assim, por sequência didática entendemos "um conjunto de atividades ordenadas, estruturadas e articuladas para a realização de certos objetivos educacionais, que têm um princípio e um fim conhecidos tanto pelos professores como pelos alunos" (ZABALA, 1998, p.18). Sob a perspectiva da Teoria das Situações Didáticas, entendemos a sequência didática como a articulação entre situações didáticas e adidáticas visando a criar um milieu, a partir da análise descendente da situação pelo professor e ascendente pelo aluno, favorável ao desenvolvimento das ideias relacionadas com determinado conceito, de modo a possibilitar a compreensão dos registros (semiósis) e a apropriação de seus significados (noésis). Cabe salientar que, ainda que não seja de forma explícita, toda situação, seja ela didática ou adidática, apresenta uma intencionalidade para a aprendizagem, que deve estar clara para o professor desde a concepção da atividade e, no caso das situações adidáticas, ser construída/compreendida pelo aluno no decorrer de suas ações.

Trata-se da estruturação de uma interface que não é apenas conceitual, mas envolve o professor, as necessidades da sala de aula e os relacionamentos que se estabelecem nesse ambiente ${ }^{15}$, todos determinantes para o sucesso da sequência didática. Esta construção é, portanto, uma tarefa complexa. Vale acrescentar que as exigências de sala de aula impõem que se tenham as aplicações de atividades em condições reais como uma obrigação inevitável. Portanto, a sequência precisa levar em consideração a realidade da sala de aula.

A sequência considera, também, a importância das intenções educacionais e o papel das atividades que são propostas na definição dos conteúdos de aprendizagem. Alguns critérios para análise das sequências reportam que os conteúdos de aprendizagem agem explicitando as intenções educativas, podendo abranger três dimensões: "dimensão conceitual - o que se deve saber?; dimensão procedimental - o que se deve saber fazer?; dimensão atitudinal - como se deve ser?" (ZABALA, 1998, p. 31).

Neste trabalho, nossas intenções educativas abrangem as dimensões conceituais, procedimentais e atitudinais no contexto de uma investigação exploratória de dados, à medida que tomamos o aluno como um pesquisador com a possibilidade de

\footnotetext{
${ }^{15}$ Em consonância com a Teoria das Situações Didáticas, que trata das relações entre professor, aluno e saber, bem como as características e influências do milieu.
} 
experienciar todas as etapas que envolvem um processo estatístico, quais sejam, coleta, organização, apresentação, análise e interpretação dos dados, de forma a perceber os conhecimentos necessários para a leitura e interpretação de gráficos e tabelas, estabelecendo e vivenciando procedimentos estatísticos para coleta, organização, análise e interpretação de dados, finalizando com o desenvolvimento do raciocínio e da literacia estatística.

As atividades de ensino a serem propostas aos estudantes devem levar em conta a formação de conceitos, a criação e a apropriação de procedimentos e a aquisição de atitudes frente à necessidade de raciocinar probabilística e estatisticamente (LOPES, 2008b, p. 74).

Zabala (1998) salienta que existem diversos tipos de sequência, não sendo possível afirmar que uma seja melhor ou pior que outra e vice-versa. O que importa é o reconhecimento das possibilidades e carências de cada uma, a fim de compreender quais tipos se adaptam melhor às necessidades educacionais de cada aluno, em determinados contextos, de acordo com o tipo de conteúdo (conceitual, procedimental ou atitudinal), principalmente com relação à avaliação.

Para reconhecer sua validade e, sobretudo, evidenciar pistas para reforçar algumas atividades ou acrescentar outras, Zabala estabelece uma série de questões sobre as atividades que compõem as diferentes sequências didáticas.

Na sequência didática existem atividades:

a) Que nos permitem determinar os conhecimentos prévios que cada aluno tem em relação aos novos conteúdos de aprendizagem?

b) Cujos conteúdos são propostos de forma que sejam significativos e funcionais para os meninos e as meninas?

c) Que possamos inferir que são adequadas ao nível de desenvolvimento de cada aluno?

d) Que representam um desafio alcançável para o aluno, quer dizer, que levam em conta sua competências atuais e as façam avançar com a ajuda necessária; portanto, que permitam criar zonas de desenvolvimento proximal e intervir?

e) Que provoquem um conflito cognitivo e promovam a atividade mental do aluno, necessária para que estabeleça relações entre os novos conteúdos e os conhecimentos prévios?

f) Que promovam uma atitude favorável, quer dizer, que sejam motivadoras em relação à aprendizagem dos novos conteúdos?

g) Que estimulem a autoestima e o autoconceito em relação às aprendizagens que se propõem, quer dizer, que o aluno possa sentir que em certo grau aprendeu, que seu esforço valeu a pena?

h) Que ajudem o aluno a adquirir habilidades relacionadas com o aprender a aprender, que lhe permitam ser cada vez mais autônomo em suas aprendizagens? (1998, p. 63-64).

Neste contexto, as sequências didáticas podem e devem passar por modificações de forma a adequá-las às situações e a conceitos particulares. A seguir, discutimos os princípios e fundamentos da integração da tecnologia na Educação Estatística, de modo a facilitar as respostas às questões apresentadas por Zabala (1998). 


\subsection{A Tecnologia como fator (res)significante no ensino de Estatística}

Apesar de não haver consenso acerca dos benefícios e/ou limitações da utilização das Tecnologias de Informação e Comunicação (TIC) como ferramenta pedagógica $^{16}$, acreditamos que esse recurso, na perspectiva construcionista apontada por Papert (1985), constitui-se como importante instrumento propulsor da atribuição de sentido às informações representadas, na medida em que pode possibilitar um processo de construção autônomo do indivíduo, bem como o registro dos processos de raciocínio dos alunos, facilitando a intervenção do professor (VALENTE, 1993; 2002).

A tecnologia se insere como uma questão de interesse social, devidamente contextualizada e problematizada, visto que está presente em todos os segmentos da sociedade.

Na verdade, a tecnologia inserida na educação diz respeito, ou à formação do indivíduo para viver na era tecnológica, de uma forma mais crítica e mais humana, ou à aquisição de conhecimentos necessários à formação profissional (tanto uma formação geral como específica), assim como a questões mais contextuais da tecnologia, envolvendo tanto a invenção como a inovação tecnológica (GRISPUN, 1999, p. 57).

$\mathrm{Na}$ verdade, essa afirmação representa, de fato, uma concepção humanística do papel da tecnologia na educação. Entretanto, também remete a uma visão da tecnologia na educação como simplesmente mais uma ferramenta de apoio educacional que pode/deve ser utilizada com a finalidade de inserção social e coerência com o contexto da sociedade e do mercado no qual se insere. Apesar de essa concepção ser mais coerente e aceitável que a política neoliberal imposta pelos organismos governamentais (particularmente o Banco Mundial), acreditamos que esse seja o grande "ponto de inflexão" para se justificar a real função e contribuição da tecnologia na educação.

Afirmações, como a de Grispun (op. cit.), têm conduzido à interpretação de que as TIC são apenas recursos instrumentais, auxiliares do processo pedagógico e não elementos estruturantes de novos processos.

De nossa parte, acreditamos que o próprio termo "inserção" não é o mais adequado: trata-se do processo de integração da tecnologia no contexto do ensino e, principalmente, aprendizagem. Significa uma mudança educacional que, segundo Valente

\footnotetext{
${ }^{16}$ Para uma discussão aprofundada do tema vide DWYER, T. et al. Desvendando mitos: os computadores e o desempenho no sistema escolar. Educ. Soc., Campinas, v. 28, n. 101, Dec. 2007. Disponível em $<$ http://www.scielo.br/scielo.php?script=sci_arttext\&pid=S0101-73302007000400003\&lng=en\&nrm=iso $>$. Acesso em: 15 dez. 2009. DOI: 10.1590/S0101-73302007000400003.
} 
(1993), deve ser acompanhada da introdução de novas ferramentas que possibilitem e facilitem o processo de expressão do pensamento, para que o indivíduo construa suas próprias representações dos objetos em estudo, aprendendo a pensar de forma autônoma e crítica. Trata-se, pois, de um novo paradigma capaz de responder a uma nova ordem histórico-social e cultural. Um paradigma

[...] que promove a aprendizagem ao invés do ensino, que coloca o controle do processo de aprendizagem nas mãos do aprendiz, e que auxilia o professor a entender que a educação não é somente a transferência de conhecimento, mas um processo de construção do conhecimento pelo aluno (VALENTE, 1993, p.42).

Para que essa nova visão passe a fazer parte das representações dos agentes do sistema educacional, é necessário que se oportunize a todos eles as condições para se tornarem sujeitos singularizados, isto é, críticos, capazes de refletir, julgar, agir e interagir, livres do processo de assujeitamento a que vêm sendo submetidos pelas políticas públicas educacionais ao longo de décadas (BONILLA; PRETTO, 2000).

É preciso, acima de tudo, entender a lógica presente no ambiente computacional. E mais, saber identificar tanto os aspectos comuns como os aspectos que diferenciam o raciocínio nesse ambiente e o raciocínio presente em atividades no papel e lápis (SANTOS; MAGINA; 2006, p. 278).

Somamos a isso o fato de que, no contexto da Educação Estatística, pesquisas apontam para as possibilidades e contribuições do uso da tecnologia e, mais particularmente, do computador, buscando fornecer aos estudantes oportunidades de usá-la para lidar com e explorar dados, de forma a enfocar mais o raciocínio e menos os cálculos e as construções (LOPES; COUTINHO, 2009).

Cabe ainda um alerta sobre a necessidade de se interligar o estudo da Probabilidade e da Estatística com a utilização das tecnologias de comunicação e informação, ampliando a possibilidade dos estudantes na inserção social, bem como viabilizando um aprofundamento nos processos de análise de dados a partir do uso das máquinas para elaboração de cálculos (LOPES, 2008b, p.84).

Portanto, para facilitar o processo de expressão do raciocínio do aluno e a intervenção pedagógica, as TIC devem estar integradas a um novo paradigma educacional no qual o professor não é mais o centro do processo, mas atua como mediador e facilitador na construção do conhecimento. O aluno não é mais instruído, ensinado. Ao contrário, desempenha o papel de protagonista no processo de construção de seu próprio conhecimento. Quando ela é arquitetada por meio do computador, temos o paradigma construcionista (PAPERT, 1985), que nega a crença de que a via para uma melhor aprendizagem deve ser o aperfeiçoamento da instrução. 
O Construcionismo é uma filosofia de uma família de filosofias educacionais que nega esta "verdade óbvia". Ele não coloca em dúvida o valor da instrução como tal. Isso seria tolo: mesmo a afirmativa (endossada, quando não originada, por Piaget) de que cada ato de ensino priva a criança de uma oportunidade para descoberta, não é o imperativo categórico contra ensinar, mas o lembrete paradoxalmente expressado para mantê-la sobre checagem. A atitude construcionista no ensino não é, em absoluto, dispensável por ser minimalista - a meta é ensinar de forma a produzir a maior aprendizagem a partir do mínimo de ensino (PAPERT, 1994, p. 124-125).

A ênfase é a presença do computador como (res)significante no processo de aprendizagem. Nesse paradigma, o aluno constrói algo de seu interesse utilizando-o como ferramenta. Ao interagir com o computador, manipula conceitos e isso contribui para o seu desenvolvimento mental, viabilizando o ciclo de construção de conhecimento (descriçãoexecução-reflexão-depuração-descrição) (VALENTE, 2002), sem a intervenção direta e/ou instrução do professor.

Embora a idéia de ciclo seja adequada para identificar as ações que o aprendiz executa e o modo como cada uma delas pode auxiliá-lo na construção de seu conhecimento, "a idéia de ciclo é limitada" (VALENTE, 2002, p. 27). Por estar envolvido num ambiente social e cultural, ele pode utilizar elementos do contexto como fontes de ideias e de informação para a busca de solução de problemas como, por exemplo, colegas, professores e pais. Portanto,

\begin{abstract}
As ações podem ser cíclicas e repetitivas, mas a cada realização de um ciclo, as construções são sempre crescentes. Mesmo errando e não atingindo um resultado de sucesso, o aprendiz está obtendo informações que são úteis na construção de seu conhecimento. Na verdade, terminado um ciclo, o pensamento nunca é exatamente igual ao que se encontrava no início de sua realização. Assim, a idéia mais adequada para explicar o processo mental dessa aprendizagem é a de uma espiral (VALENTE, 2002, p. 27).
\end{abstract}

A idéia de espiral não só é mais adequada para a compreensão do modo como o computador pode auxiliar na aprendizagem, como também permite separar certas ações e entendê-las de modo mais amplo, dando abertura para a compreensão de que o processo de aprendizagem não é apenas cognitivo, mas sofre influências emocionais e sociais, por exemplo (ibidem.).

$\mathrm{Na}$ espiral proposta por Valente (2002), por meio da interação aprendizcomputador, ocorre a descrição feita pelo usuário e que ordenará a ação da máquina execução - produzindo um resultado. A partir do resultado obtido, o indivíduo irá compará-lo com o pressuposto inicial. Caso o resultado seja o esperado, a espiral está terminada e, consequentemente, o conceito construído. Em havendo divergências, é iniciado o processo de reflexão, de forma a identificar os erros cometidos por meio de soluções de conflitos decorrentes da divergência entre o pressuposto inicial e o resultado gerado pela máquina. As 
soluções se dão por meio do desenvolvimento de abstrações progressivas, que possibilitam a passagem de um nível inicial para outros mais elaborados de desenvolvimento.

As abstrações podem ser empíricas - quando o indivíduo extrai algum conhecimento a partir, apenas, do objeto; pseudo-empíricas - quando se deduz algum conhecimento a partir do objeto e/ou das ações realizadas; e reflexionante - que engloba dois aspectos: o reflexionamento, que consiste em projetar sobre um patamar superior o que é extraído de um patamar inferior; e a reflexão, que é o ato mental de reconstruir e/ou reorganizar os conhecimentos projetados ao patamar superior. A partir desse processo, tornam-se possíveis as mudanças conceituais e construções de novos conhecimentos, ou seja, por meio da depuração, vai se refinando o conceito em questão.

Trata-se de proporcionar efetivamente a implementação do paradigma construcionista, no qual, por meio da ação e reflexão quanto aos resultados obtidos, o aluno depura seus erros e equívocos, amplia suas idéias e compreensões, construindo conhecimento significativo e fundamentado. Portanto, com o mínimo de instrução torna-se possível obter o máximo de aprendizagem, porque ela é dinamizada pela significativa influência do meio no qual as atividades e interações são desenvolvidas. Daí a importância de se promover um milieu favorável à mobilização da curiosidade e descoberta, mas antagônico no sentido de facilitar a reflexão, interação e depuração de erros e equívocos.

Em síntese, a espiral de aprendizagem pode ocorrer no contexto da resolução de uma situação-problema utilizando uma linguagem de programação. Quando se resolve o problema, é possível refinar o(s) conceito(s) envolvido(s), na medida em que é necessário “ensinar" ao computador os procedimentos e estratégias para solução da situação. Para tanto, é necessário refletir e explicitar o raciocínio utilizado para a resolução do problema.

Cabe salientar a função do professor nesse contexto, que, diante da interação aluno-computador, passa a ter o papel de mediador, sendo que o modelo que melhor descreve a forma de atuação desse mediador é fornecido por Vygotsky, segundo o qual, o mediador é efetivo, quando age na Zona Proximal de Desenvolvimento (ZPD) (VALENTE, 1993), definida como

[...] a distância entre o nível de desenvolvimento atual, determinado pela resolução de problema independente e o nível de desenvolvimento potencial, determinado através da resolução de problemas sob auxílio do adulto ou em colaboração com colegas mais capazes (VYGOTSKY, 1989, p. 86).

Neste trabalho, optamos por utilizar dois softwares: O Microsoft Excel e o SuperLogo 3.0. A seguir, apresentamos algumas considerações sobre cada um deles, bem 
como uma análise à luz das orientações de Hernandes (1998) e Valente (1999), visando a explicitar os motivos de nossas escolhas, haja vista que

\begin{abstract}
A importância do software aparece como um elemento que delineia os limites e as possibilidades do computador, interferindo na abordagem pedagógica. Nos programas estão contidos conceitos, preconceitos, informações, conteúdos e concepções educacionais que influem no contexto de trabalho educativo. A presença do computador se interrelaciona com a presença do software, onde a interface media a interação do sujeito com o objeto de conhecimento veiculado por ela (HERNANDES, 1998, p. 35).
\end{abstract}

Dessa forma, uma discussão quanto à estrutura de cada software pode explicitar suas potencialidades e limitações, de modo a orientar o planejamento de atividades consonantes com essas características.

\title{
2.4.1O Microsoft Excel
}

O Microsoft Excel não é um software direcionado para ambientes educacionais. Trata-se de um aplicativo comercial de fácil acesso que, segundo nossas constatações, é utilizado no contexto escolar para suprir a deficiência de softwares educacionais voltados para a área de Estatística. Não encontramos trabalhos voltados para a construção e/ou utilização de objetos de aprendizagem no contexto da área em questão, originando a necessidade de se estudarem alternativas para superar essas limitações.

O Excel é um aplicativo Windows - uma planilha eletrônica - que fornece ferramentas para efetuar cálculos através de fórmulas e funções e para a análise de dados. São cinco suas principais funções:

Planilhas: é possível armazenar, manipular, calcular e analisar dados tais como números, textos e fórmulas. Além disso, o Excel possibilita acrescentar gráficos diretamente em uma planilha, elementos gráficos, tais como retângulos, linhas, caixas de texto e botões, além de possibilitar a utilização de formatos pré-definidos em tabelas.

Bancos de dados: permite classificar, pesquisar e administrar facilmente uma grande quantidade de informações utilizando operações padronizadas de bancos de dados.

Gráficos: é possível rapidamente apresentar de forma visual uma representação de dados. Além de escolher tipos pré-definidos de gráficos, há a possibilidade de personalizar qualquer gráfico da maneira desejada.

Apresentações: o Excel permite usar estilos de células, ferramentas de desenho, galeria de gráficos e formatos de tabela para criar apresentações de alta qualidade. 
$\operatorname{Macros}^{17}$ : as tarefas que são frequentemente utilizadas podem ser automatizadas pela criação e armazenamento de suas próprias macros.

O Excel representa um software dinâmico e de fácil acesso às escolas públicas. Acreditamos que a utilização de um aplicativo de planilhas eletrônicas em sala de aula pode abrir possibilidades para o desenvolvimento de um saber crítico que conduz à escolha de um trabalho diferenciado, em que os alunos se desenvolvem de forma mais criativa e crítica (REBELO, KOVATLI; BARBETA, 2002).

Além disso, pela sua própria estrutura de planilha eletrônica, pode contribuir para a organização dos dados a fim de facilitar as interações fundamentais da Teoria das Situações Didáticas, bem como os cálculos e atividades necessários para a organização, leitura e interpretação dos dados, por meio de tabelas.

Aqui vale uma ressalva: ainda que o aplicativo possibilite a construção de gráficos a partir de dados organizados em tabelas, acreditamos que essa facilidade pode, e deve, ser explorada quando os alunos apresentarem um certo domínio dos conhecimentos e estruturas estatísticas. À medida que o processo de construção de gráficos no Excel é automatizado, a tomada de consciência e o estabelecimento das relações entre os dois tipos de registro (tabela e gráfico) ficam comprometidos, assim como as próprias relações existentes no gráfico (por exemplo, a relação eixo-barra, num gráfico deste tipo).

Em consequência, acreditamos que uma atividade menos automatizada, mesmo sendo mais trabalhosa, seja mais relevante para os alunos do Ensino Fundamental, podendo o Excel ser utilizado em níveis mais elevados de letramento.

\subsubsection{Análise do Microsoft Excel}

O Microsoft Excel é um aplicativo de navegação fácil, tendo em vista sua própria estrutura de planilha eletrônica, que possibilita a realização de diversas atividades, desde cálculos simples, como a totalização de uma linha ou coluna, até a elaboração de um resumo estatístico a partir de um conjunto de dados por meio de um único comando (Resumo Estatístico). Da mesma maneira, possibilita construção de gráficos, de acordo com modelos previamente existentes no próprio aplicativo, a partir de dados organizados em tabela.

Quanto aos aspectos algébricos, algumas funções são um pouco complexas, porque se baseiam em linguagem de programação. No entanto, para cálculos simples,

\footnotetext{
${ }^{17}$ Macro, na Ciência da Computação, é uma abstração que define como um padrão de entrada deve ser
} substituído por um padrão de saída, de acordo com um conjunto de regras. 
apresenta uma estrutura de comandos bastante fácil e clara, semelhante aos cálculos realizados com calculadoras.

Apresenta o menu Ajuda, no qual é possível obter orientações quanto aos comandos existentes, facilitando a navegação do usuário, que não é muito simples, considerando que os caminhos de navegação não são flexíveis, tendo em vista que as barras de comandos são fixas e suas funções não são muito evidentes (em alguns casos).

No âmbito da estética, se bem que seja adequada para um software comercial de planilha eletrônica, não apresenta animações e sons, de modo a integrar várias mídias. Exceto pelas relações estabelecidas entre os dados apresentados em tabelas e os gráficos que podem ser construídos a partir deles, o Excel não demonstra "preocupação" com aspectos estéticos, optando por uma diagramação mais funcional que harmônica e/ou agradável ao usuário. No entanto, as informações e conceitos apresentados são claros e objetivos. Talvez a linguagem utilizada possa caracterizar certa dificuldade, quando pensamos no trabalho com crianças e adolescentes, em razão do registro extremamente formal com termos pouco conhecidos pela população em geral.

Quanto aos aspectos pedagógicos, o Excel, por sua própria estrutura comercial e não educacional, não visualiza características significativas, gerando a necessidade de o professor criar situações que, de fato, proporcionem a aprendizagem efetiva e o desenvolvimento do raciocínio. Caso contrário, o uso do Excel poderá caracterizar simplesmente a automatização de um cálculo ou da construção de um gráfico utilizando o computador, o que não é interessante para o processo de aprendizagem na perspectiva construcionista que defendemos. Cabe salientar que o Excel não possibilita o registro do raciocínio do aluno, haja vista que é baseado apenas na relação comando-resposta, dificultando, portanto, a mediação do professor e o processo de reflexão-depuração por conta do aluno.

Fica evidente que o professor tem um papel essencial na construção de atividades que não se restrinjam à instrução e/ou aprendizagem de comandos técnicos desse aplicativo, mas que mobilizem idéias e conceitos no sentido de possibilitar a espiral de aprendizagem. A oralidade do aprendiz e do professor é o canal de comunicação entre os agentes que possibilita a interlocução e o estabelecimento de milieux favoráveis à construção do conhecimento, bem como a criação de situações adaptáveis ao contexto e aos indivíduos envolvidos no processo de aprendizagem.

O Excel envolve estruturas lógicas em seus comandos e, apesar de realizar as operações de maneira não explícita, os resultados apresentados para cada comando decorrem 
de operações lógicas e matemáticas. Assim, embora sua estrutura não apresente características que facilitem um paradigma construcionista, com uma atuação mais efetiva do professor na elaboração e gestão das atividades didáticas, o software também pode proporcionar a construção do conhecimento por meio da espiral da aprendizagem. Exige apenas mais intensa "participação" do professor na criação de um ambiente de aprendizagem voltado a esse propósito.

\subsubsection{O SuperLogo 3.0}

Seymour Papert trabalhou durante cinco anos com crianças para analisar como elas pensavam, com a intenção de construir máquinas com princípios semelhantes ao raciocínio infantil. A partir da reflexão simultânea sobre como as crianças pensam e como os computadores poderiam pensar, Papert criou uma linguagem computacional voltada para elas, mas com todas as características de uma linguagem de programação. Trata-se da linguagem de programação LOGO, em que, utilizando conceitos matemáticos, as crianças "ensinam" a $\operatorname{tartaruga}^{18}$ a agir.

Dois grandes temas orientaram as investigações de Papert sobre computadores e educação: as crianças podem aprender a usar computadores habilmente e essa aprendizagem pode mudar a maneira como elas conhecem as coisas.

Por outro lado, Papert propõe que as ideias incorporadas pela linguagem LOGO não se limitem ao uso do computador, mas que possibilitem o processo de reflexão sobre a ação em outros ambientes e situações.

Os ambientes intelectuais oferecidos às crianças pelas sociedades atuais são pobres em recursos que as estimulem a pensar sobre o pensar, aprender a falar sobre isto e testar suas ideias através da exteriorização das mesmas. $\mathrm{O}$ acesso aos computadores pode mudar completamente esta situação. Até o mais simples trabalho com a tartaruga pode abrir novas oportunidades para tornar mais acurado nosso ato de pensar sobre o pensar: programar a tartaruga começa com a reflexão sobre como nós fazemos o que gostaríamos que ela fizesse; assim, ensiná-la a agir ou pensar pode levar-nos a refletir sobre nossas próprias ações ou pensamentos (PAPERT, 1985, p. 45).

A linguagem da tartaruga representa, portanto, uma linguagem de programação que foi desenvolvida para ser utilizada com finalidades educacionais, podendo ser aplicada em vários domínios de conhecimento, já que permite ao usuário resolver problemas diversos relacionados com música, artes, matemática, línguas, etc...

\footnotetext{
${ }^{18} \mathrm{O}$ cursor gráfico da linguagem é apresentado na forma de uma tartaruga, que acabou se tornando o símbolo da linguagem LOGO.
} 
Com a utilização da linguagem LOGO, os

\begin{abstract}
Alunos que interagem com a tartaruga Logo e seus professores podem se beneficiar das possibilidades de estabelecimento de relações que o Logo propicia de uma forma que, muitas vezes, não se dá na escola: problemas podem ser propostos pelo professor ou pelo aluno e as soluções podem ser testadas e ajustadas de tal forma que o erro não seja um bloqueador a ser evitado, mas um caminho para o acerto (GREGOLIN, 2008, p.9).
\end{abstract}

Outro aspecto importante nas concepções de Papert é considerar o erro como um importante fator de aprendizagem, em razão de ele oferecer oportunidade para que o aluno entenda por que errou e busque uma nova solução para o problema, investigando, explorando, descobrindo por si próprio, ou seja, aprendendo pela descoberta.

Neste trabalho, utilizamos o software livre SuperLogo 3.0, desenvolvido pelo Núcleo de Informática Aplicada à Educação (Nied) da Universidade Estadual de Campinas (Unicamp).

Por meio de seus comandos, o SuperLogo 3.0 facilita o desenvolvimento de uma série de conceitos espaciais e numéricos, através da construção de figuras em sua área de trabalho. Acreditamos que essa característica pode enriquecer o processo de construção consciente de gráficos de barras, linhas e setores, além de possibilitar a análise do raciocínio dos alunos no decorrer do processo de construção gráfica, por meio dos registros dos comandos utilizados. Além disso, para a construção da representação de dados, os educandos precisam utilizar uma série de conceitos matemáticos. Em consequência, descobrirão novos conhecimentos para agregar aos já adquiridos. É uma linguagem de fácil utilização, mesmo com crianças pequenas, já que seus comandos são em português e envolvem termos do dia-adia (VALENTE, 1993).

O ambiente SuperLogo 3.0 é composto por duas janelas: a gráfica e a de comandos. No centro da primeira, aparece a figura de uma tartaruga, um cursor gráfico, que, a partir de comandos específicos, se movimenta na tela, possibilitando a criação de desenhos. A segunda, aquela de comandos, permite ao usuário digitar as instruções a serem executadas pela tartaruga.

A movimentação da tartaruga na janela gráfica pode ser feita por meio de comandos de deslocamento e giro: parafrente (ou pf), paratras (ou pt), paradireita (ou pd) para esquerda (ou pe). Além do comando, é necessário indicar o número de passos (pf 100) ou o grau do giro (pd 90).

A exploração dos comandos, quando feita de modo direto, isto é, quando executados a partir da janela de comandos, permite que o usuário veja imediatamente o resultado na janela gráfica. No entanto, tal tipo de utilização não permite que as informações 
sejam armazenadas na memória do computador para uso posterior. Para fazê-lo, é necessário utilizar o modo de edição, com o qual, por meio da definição e construção de procedimentos, é possível armazenar uma sequência de instruções na memória do computador, que pode ser utilizada posteriormente, sempre que o usuário necessitar. Cabe salientar que o menu Modo de Execução ativa um procedimento simples e direto para a depuração do programas no SuperLogo 3.0. Trata-se do recurso Passo-a-passo que, quando ativado, executa um procedimento no LOGO mostrando cada um dos comandos utilizados. Dessa maneira, é possível identificar erros e equívocos para depurá-los.

\subsubsection{Análise do SuperLogo 3.0}

O software é baseado na linguagem de programação LOGO que, de acordo com Valente (1999), em virtude de o programa utilizar conceitos e estratégias para o desenvolvimento das ações, atribui ao computador a condição de meio para resolução de problemas. Como resultado, essa característica propicia a espiral da aprendizagem, de modo que aluno aprende autônoma e ativamente.

Trata-se de uma linguagem fácil e flexível, que pode ser utilizada no modo direto ou por meio da criação de procedimentos. Além disso, as mensagens de erro são claras, facilitando a compreensão dos alunos e a depuração do erro de comando. A possibilidade de utilizar cores e diversas formas funciona também como um diferencial estético que contribui para o envolvimento e interesse dos alunos no desenvolvimento das atividades. O próprio cursor em formato de tartaruga, característico da linguagem LOGO, mostra-se como um diferencial gráfico para o software. No entanto, o SuperLogo 3.0 também não apresenta animações e sons, o que poderia agregar valor quanto a sua estética.

Quanto ao aspecto computacional do LOGO, Valente destaca que se trata de uma linguagem criada com o objetivo de "implementar uma metodologia de ensino baseada no computador (metodologia LOGO)" (1993, p. 15), explorando aspectos da aprendizagem. Dessa forma, visa a romper com as atividades nas quais o computador ensina a criança para proporcionar que a criança aprenda resolvendo problemas que necessitam de determinados raciocínios e conceitos para sua solução. A linguagem LOGO possibilita a explicitação desses raciocínios e essas idéias de modo a facilitar a intervenção do professor, bem como a depuração pelo próprio aluno, pois "a verdadeira função do aparato educacional não deve ser a de ensinar, mas sim a de criar condições de aprendizagem" (ibidem, p. 6). 
A linguagem, portanto, caracteriza um novo paradigma educacional, que supera a noção de que informática educacional nada mais é que a informatização de métodos tradicionais de ensino (instrucionismo). Ele, ao contrário, fundamentado no construtivismo piagetiano, firma-se nos pressupostos de que o aprendiz deve construir alguma coisa, ou seja, a aprendizagem ocorre pelo ato de fazer e construir algo do próprio interesse. " $\mathrm{O}$ envolvimento afetivo torna a aprendizagem mais significativa" (VALENTE, 1993, p. 33).

Quanto aos aspectos pedagógicos, em razão de os comandos serem registrados e envolverem conceitos, desde os mais básicos (pf e pt, por exemplo) aos mais complexos (construção de um quadrado de lado 50, por exemplo), o SuperLogo 3.0 evidencia dificuldades e deficiências de aprendizagem, de modo que se adapta às necessidades dos alunos, possibilitando a intervenção pontual do professor e o avanço de todos, independente do nível de conhecimento de cada um. Além disso, as dúvidas podem ser socializadas, a fim de proporcionar o trabalho coletivo e colaborativo.

Essa característica explicita a interatividade do SuperLogo 3.0, a qual possibilita que o aluno construa conhecimento a partir da reflexão sobre as (possíveis) inconsistências detectadas entre a expectativa inicial ao indicar determinado comando (ou construir um procedimento) e a ação realizada pela tartaruga a partir do comando indicado. Vai ao encontro, portanto, do princípio construcionista de proporcionar a maior aprendizagem a partir do mínimo de ensino.

O aprendiz é ativo na construção de seu conhecimento, facilitando a atribuição de significado aos conceitos e ideias envolvidos na atividade. Trata-se do desenvolvimento do raciocínio lógico e da aplicação de diversos conceitos matemáticos no desenvolvimento dos procedimentos na linguagem da tartaruga. Para tanto, ele interage com o computador e, portanto, aprende fazendo, ou seja, ensinando a tartaruga a resolver o problema, apresentando uma descrição precisa e formal do processo de resolução. Assim, o resultado da execução da tartaruga (decorrente do comando indicado) permite que ele compare suas idéias originais com o resultado obtido, de modo a analisar a adequação e a correção dos conceitos e idéias aplicados.

Portanto, no Logo, o erro deixa de ser uma arma de punição e passa a ser uma situação que nos leva a entender melhor nossas ações e conceitualizações. É assim que a criança aprende uma série de conceitos antes de entrar na escola. Ela é livre para explorar e os erros são usados para depurar os conceitos e não para se tornarem uma arma do professor (VALENTE, 1993, p. 19).

A atividade no SuperLogo 3.0 torna explícito, portanto, o processo de aprendizagem, tanto quanto à elaboração de estratégia de solução de um problema quanto à 
utilização de conceitos nessa solução. Considerando que, com os métodos tradicionais de ensino, essa explicitação é muito difícil, a linguagem LOGO, de fato, pode resgatar uma aprendizagem construtivista e provocar uma mudança profunda das metodologias e práticas de ensino, possibilitando a implementação de um novo paradigma educacional, mais coerente com as necessidades da escola contemporânea.

Por fim, independente das características de um software, seja ele mais favorável ao Construcionismo ou ao Instrucionismo, aqui entendido como a crença de que a via para uma melhor aprendizagem deve ser o aperfeiçoamento da instrução (VALENTE, 2002), o professor tem papel fundamental para a integração eficiente do computador à educação, na medida em que pode e deve criar situações que explorem o software de maneira plena e adequada. Mais importante que o tipo de software que se tem em mãos é o tipo de uso que se faz dele (VALENTE, 1999). 


\section{ANÁLISES PRELIMINARES: (re)conhecendo o estado atual do ensino e aprendizagem de Estatística}

Iniciamos a organização da sequência de atividades por meio da estruturação de um quadro teórico geral da situação atual do tratamento da Estatística no Ensino Fundamental. Com o objetivo de identificar os problemas quanto ao ensino e à aprendizagem, particularmente no âmbito da construção, leitura e interpretação de gráficos e, dessa forma, delinear as atividades de experimentação, analisamos currículos prescritos, livros didáticos, orientações, avaliações e pesquisas. O material recolhido orientou a construção da sequência didática que será apresentada no quarto capítulo.

\subsection{Parâmetros Curriculares Nacionais}

Os Parâmetros Curriculares Nacionais (PCN) de Matemática para o terceiro e quarto ciclos do Ensino Fundamental fornecem subsídios para ampliar o debate sobre o ensino dessa ciência. Trata-se de um guia curricular que pode orientar o trabalho pedagógico dos professores e contribuir para a formação dos alunos. Além disso, tem como objetivo orientar a formação continuada dos profissionais da Educação e a elaboração de livros e material didático de apoio às práticas educativas.

Os conteúdos matemáticos do documento são apresentados em quatro blocos: Números e Operações, Espaço e Forma, Grandezas e Medidas e Tratamento da Informação. Os conteúdos de interesse desta pesquisa encontram-se distribuídos no último bloco, no qual o que se pretende não é o desenvolvimento de um trabalho baseado exclusivamente na definição de termos e fórmulas relacionadas à Probabilidade e Estatística.

Com relação à Estatística, a finalidade é fazer com que o aluno venha a construir procedimentos para coletar, organizar, comunicar dados, utilizando tabelas, gráficos e representações que aparecem frequentemente em seu dia-a-dia. Além disso, calcular algumas medidas estatísticas como média, mediana e moda, com o objetivo de fornecer novos elementos para interpretar dados estatísticos. Com relação à probabilidade, a principal finalidade é a de que o aluno compreenda que muitos dos acontecimentos do cotidiano são de natureza aleatória e que se podem identificar possíveis resultados desses acontecimentos e até estimar o grau de possibilidade acerca do resultado de um deles. As noções de acaso e incerteza, que se manifestam intuitivamente, podem ser exploradas na escola, em situações em que o aluno realiza experimentos e observa eventos (em espaços equiprováveis) (BRASIL, 1998, p.52).

A Estatística apresenta-se, portanto, "com o objetivo de coletar, organizar, comunicar e interpretar dados, por meio da utilização de tabelas, gráficos e representações, para tornar o estudante capaz de descrever e interpretar sua realidade, usando conhecimentos 
matemáticos" (LOPES; CARVALHO, 2009, p. 88). A probabilidade visa à compreensão da variabilidade e do acaso nos acontecimentos cotidianos, de modo a romper com a visão determinística presente na Matemática.

O documento secciona os conteúdos, competências e habilidades a serem desenvolvidas no Ensino Fundamental, em quatro ciclos. O terceiro ciclo compreende a quinta e sexta séries ( $6^{\circ}$ e $7^{\circ}$ anos), enquanto o quarto ciclo refere-se à sétima e oitava $\left(8^{\circ}\right.$ e $9^{\circ}$ anos).

Para o desenvolvimento do raciocínio estatístico e probabilístico no terceiro ciclo, o documento propõe a exploração de situações que envolvam coleta, organização e análise de informações; construção e interpretação de tabelas e gráficos; formulação de argumentos convincentes fundamentados nas representações matemáticas e determinação de uma probabilidade de sucesso por meio de uma razão. Os PCN consideram o desenvolvimento de conteúdos de forma mais ampla, tendo em vista que "envolvem explicações, formas de raciocínio, linguagens, valores, sentimentos, interesses e condutas" (BRASIL, 1998, p. 49).

Conceitos permitem interpretar fatos e dados e são generalizações úteis que permitem organizar a realidade, interpretá-la e predizê-la. Sua aprendizagem desenvolve-se de forma gradual e em diferentes níveis e supõe o estabelecimento de relações com conceitos anteriores. [...] Os procedimentos por sua vez estão direcionados à consecução de uma meta e desempenham um papel importante, pois grande parte do que se aprende em Matemática são conteúdos relacionados a procedimentos. Os procedimentos não devem ser encarados apenas como aproximação metodológica para aquisição de um dado conceito, mas como conteúdos que possibilitem o desenvolvimento de capacidades relacionadas com o saber fazer, aplicáveis a distintas situações. Esse saber fazer implica construir as estratégias e os procedimentos, compreendendo os conceitos e processos neles envolvidos. Nesse sentido, os procedimentos não são esquecidos tão facilmente. Exemplos de procedimentos: resolução de uma equação, traçar a mediatriz de um segmento com régua e compasso, cálculo de porcentagens etc (BRASIL, 1998, p. 49-50).

Os conceitos e procedimentos a serem desenvolvidos nesse ciclo são:

- coleta, organização de dados e utilização de recursos visuais adequados (fluxogramas, tabelas e gráficos) para sintetizá-los, comunicá-los e permitir a elaboração de conclusões.

- leitura e interpretação de dados expressos em tabelas e gráficos.

- compreensão do significado da média aritmética como indicador de tendência de uma pesquisa.

- representação e contagem dos casos possíveis em situações combinatórias.

- construção do espaço amostral e indicação da possibilidade de sucesso de um evento pelo uso de uma razão (BRASIL, 1998, p. 74-75).

No quarto ciclo, o objetivo do desenvolvimento de idêntico raciocínio deve ser atingido por meio de situações que levem o aluno a construir tabelas de frequências e a reproduzir graficamente, utilizando diferentes recursos, representações que possibilitem a 
elaboração de análises e retirada de conclusões, a partir da leitura de dados. No que concerne à probabilidade, o aluno deverá ser capaz de construir um espaço amostral de eventos equiprováveis, utilizando o princípio multiplicativo para estimar a probabilidade de sucesso de um evento. Os conceitos e procedimentos a serem desenvolvidos nesse ciclo são:

- leitura e interpretação de dados expressos em gráficos de colunas, de setores, histogramas e polígonos de frequência;

- organização de dados e construção de recursos visuais adequados, como gráficos (de colunas, de setores, histogramas e polígonos de frequência) para apresentar globalmente os dados, destacar aspectos relevantes, sintetizar informações e permitir a elaboração de inferências;

- compreensão de termos como frequência, frequência relativa, amostra de uma população para interpretar informações de uma pesquisa;

- distribuição de frequências de determinada variável de uma pesquisa em classes, de modo que resuma os dados com um grau de precisão razoável;

- obtenção das medidas de tendência central de uma pesquisa (média, moda e mediana), compreendendo seus significados para fazer inferências;

- construção do espaço amostral, utilizando o princípio multiplicativo e a indicação da probabilidade de um evento por meio de uma razão;

- elaboração de experimentos e simulações para estimar probabilidades e verificar probabilidades previstas (BRASIL, 1998, p.90).

Para o $4^{\circ}$ ciclo, os PCN "sugerem um destaque especial para o tratamento da informação, pelo fato de o aluno ter melhores condições de desenvolver pesquisas de acordo com sua realidade" (LOPES; CARVALHO, 2009, p. 88). Os guias aventam, ainda, algumas atitudes a serem desenvolvidas nos respectivos ciclos, orientações pedagógicas, bem como parâmetros norteadores para a avaliação. Quanto ao Tratamento da Informação, destaca-se a verificação da capacidade de o aluno coletar e organizar dados em tabelas e gráficos apropriados, de realizar a leitura correta desses dados, bem como de indicar a probabilidade de ocorrência de um evento por meio de uma razão.

Os PCN “consideram também que o ensino da Probabilidade e da Estatística favorece o aprofundamento, a ampliação e a aplicação de conceitos e procedimentos de vários conteúdos matemáticos" (LOPES; CARVALHO, 2009, p. 88). 


\title{
3.2 O Currículo do Estado de São Paulo
}

A Proposta Curricular do Estado de São Paulo (PCSP) para o Ensino Fundamental Ciclo II $^{19}$ e Ensino Médio foi elaborada pela Secretaria da Educação do Estado de São Paulo (SEESP) e entrou em vigência no ano de 2008. Tem por objetivo apoiar o trabalho realizado nas escolas estaduais paulistas, visando à melhoria do ensino. Esse guia curricular propõe um trabalho centrado em competências, tencionando a promoção dos conhecimentos próprios de cada disciplina a partir das habilidades e competências do aluno.

A PCSP foi dividida em quatro grandes áreas: Ciências Humanas e suas Tecnologias; Ciências da Natureza e suas Tecnologias; Linguagens, Códigos e suas Tecnologias e Matemática e as Áreas do Conhecimento. A criação de uma área específica para a Matemática é justificada pela sua especificidade, que "resulta esmaecida quando ela é agregada seja ao grupo das linguagens em sentido amplo, ou seja, ao grupo das ciências" (SÃO PAULO, 2008, p. 38).

Além disso, a PCSP está constituída a partir de três eixos norteadores: expressão/compreensão, argumentação/decisão e contextualização/abstração.

\begin{abstract}
Nos três eixos citados, o papel da Matemática é facilmente compreensível e, sem dúvida, fundamental. No primeiro eixo, ao lado da língua materna, a Matemática compõe um par complementar como meio de expressão e de compreensão da realidade. [...] No eixo argumentação/decisão, o papel da Matemática como instrumento para o desenvolvimento do raciocínio lógico, da análise racional - tendo em vista a obtenção de conclusões necessárias - é bastante evidente. [...] No que se refere ao terceiro eixo de competências, a Matemática é um lugar (ou instância) bastante adequado ou mesmo privilegiado para se aprender a lidar com os elementos do par concreto/abstrato (SÃO PAULO, 2008, p. 42-43).
\end{abstract}

Propondo um currículo fundamentado no desenvolvimento de competências, de acordo com a avaliação do Exame Nacional do Ensino Médio (ENEM), foram estabelecidas 05 (cinco) competências associadas a algumas capacidades a serem desenvolvidas, conforme segue:

- competência I, associada à capacidade de expressão em diferentes linguagens, incluídas a língua materna, a Matemática, as artes, entre outras;

- competência II, associada à capacidade de compreensão de fenômenos, que inclui desde a leitura de um texto até a "leitura" do mundo;

\footnotetext{
${ }^{19}$ Enquanto os PCN subdividem o Ensino Fundamental (EF) em 4 ciclos, a PCSP o fraciona em 2, sendo que o primeiro compreende as séries iniciais do EF ( $1^{\circ}$ ao $5^{\circ}$ ano) e o segundo, as séries finais (do $6^{\circ}$ ao $9^{\circ}$ ano).
} 
- competência III, associada à capacidade de contextualizar, de enfrentar situações-problema, ficando implícita a valorização da imaginação, da necessária abstração quando se criam novos contextos;

- competência IV, associada à capacidade de argumentar de modo consistente, de desenvolver o pensamento crítico; e

- competência V, associada à capacidade de decidir, após as análises argumentativas e elaborar propostas de intervenção solidária na realidade.

Analisando a proposta na perspectiva da temática do bloco Tratamento da Informação, podemos afirmar que o documento atribui significativa importância à Estatística na formação escolar, considerando que sua utilização viabiliza o desenvolvimento da interpretação, reflexão e aplicação de conceitos matemáticos no cotidiano, tornando a ciência mais significativa e próxima do aprendiz. Além disso, o documento salienta que a representação de dados e o Tratamento da Informação podem abrir espaço para a incorporação crítica das TIC no ensino. Quanto aos conteúdos a serem trabalhados, o documento propõe sua abordagem no terceiro e quarto bimestres letivos sendo:

- na $5^{\mathbf{a}}$ série ( $6^{\mathbf{0}}$ ano): leitura e construção de gráficos e tabelas, média aritmética e problemas de contagem;

- na $6^{\mathbf{a}}$ série ( $7^{\mathbf{0}}$ ano): construção de gráficos de setores e problemas envolvendo probabilidade;

- na $8^{\mathrm{a}}$ série ( $\left(^{\circ}\right.$ ano): problemas de contagem e introdução à probabilidade.

A PCSP não faz referência alguma a atividades, conceitos, habilidades ou competências acerca da temática em questão a serem trabalhadas na $7^{\mathrm{a}}$ série ( $8^{\mathrm{o}}$ ano) do EF.

\subsubsection{Os cadernos do Professor da PCSP para o Ensino Fundamental}

O Caderno do Professor é um material distribuído para professores de $5^{\mathrm{a}}$ a $8^{\mathrm{a}}$ séries do Ensino Fundamental e do Ensino Médio no Estado de São Paulo, de acordo com as orientações da PCSP. É composto de 76 cadernos organizados por bimestre, por série e por matéria, em que se indica, de forma pormenorizada, o conteúdo a ser ministrado aos alunos da rede pública estadual.

A análise dos cadernos do professor possibilita uma comparação entre o que está proposto na PCSP e as atividades elaboradas para serem desenvolvidas em sala de aula. 
De acordo com o caderno da $8^{\mathrm{a}}$ série do Ensino Fundamental do $4^{\circ}$ bimestre de 2008, a última atividade a ser desenvolvida com os alunos trata do conceito de Probabilidade associado à Geometria. Para tanto, as atividades estão pautadas no:

$\rightarrow$ "Problema das Agulhas de Buffon": por meio de uma situação aparentemente despretensiosa, é possível associar a Probabilidade à Geometria, num contexto real. O problema está fundamentado no estabelecimento de um modelo, por meio de experimentações sucessivas, que aponte a probabilidade de uma agulha cair sobre uma linha, a partir de um tabuleiro composto de linhas paralelas (com intervalos maiores que o tamanho das agulhas). Como conclusão de suas investigações, o conde de Buffon chegou à seguinte fórmula: $P=\frac{2 a}{\pi \cdot d}$, onde $P$ é a probabilidade de a agulha cair sobre uma das linhas do tabuleiro, $a$ é o comprimento da agulha e $d$ é a distância entre as linhas paralelas. Dessa forma, apesar de pouco provável, o problema estabelece uma relação entre a Probabilidade e a Geometria Métrica, particularmente a circunferência.

$\rightarrow \quad$ "Roleta num Setor Circular": utilizando os ângulos de cada setor (tendo em vista que os raios são os mesmos), os alunos devem calcular a probabilidade de se obter um determinado resultado a partir do giro de uma roleta, associando probabilidade com setores circulares.

$\rightarrow$ “Área de Coroas Circulares": pensando num alvo (com espaço amostral equiprovável), os alunos devem calcular as probabilidades de se atingir cada uma de suas regiões (coroas circulares). Em consequência, eles podem perceber que, apesar de parecerem do mesmo tamanho (partindo do princípio de que o raio do círculo central e os espaçamentos entre cada uma das coroas têm a mesma medida), a probabilidade de se atingir a região externa do alvo é muito superior à de se atingir o centro. Ao final, são convidados a construir um "alvo democrático", isto é, um alvo em que cada uma das regiões tenha a mesma probabilidade de chance de ser atingida num determinado lançamento de um dardo.

As atividades são interessantes e remetem a outros conceitos matemáticos (área do círculo, setor e coroas circulares, proporcionalidade e porcentagem). Além disso, possibilitam a passagem do campo discreto para o campo contínuo, já que os espaços amostrais e os eventos não são contados, mas medidos. A probabilidade favorável é calculada por meio da comparação de medidas de áreas e ângulos e não pela razão entre número de casos favoráveis de um evento e o número de casos possíveis.

No entanto, as atividades propostas necessitam de uma complementação substancial, bem como de um preparo do professor para lidar com os referidos conceitos. 
Anteriormente a essa atividade, no contexto da probabilidade, a PCSP tão somente prevê a introdução da ideia na $6^{\mathrm{a}}$ série, como uma razão particular entre casos favoráveis e possíveis de um determinado evento. O próprio caderno salienta a necessidade de se proporem e realizarem, anteriormente, atividades que envolvam a ideia de probabilidade, por meio de experimentação. Além disso, apesar de apontados na PCSP, as atividades não preveem problemas de contagem, os quais ficaram preteridos neste nível de formação, já que o documento apenas sinaliza sua introdução na quinta série, para aprofundá-los e contextualizálos na oitava.

\subsection{Livro Didático}

Como complementação de nossas investigações preliminares, optamos por analisar a coleção de livros didáticos que, segundo a coordenadora, tem sido utilizada na Escola A nos último três $\operatorname{anos}^{20}$, tendo em vista que "um olhar cuidadoso sobre os livros didáticos recomendados para o ensino fundamental, auxilia na percepção da concepção de ensino de probabilidade e estatística que predomina em nossa escola básica” (LOPES; MORAN, 1999, p. 167).

Lopes e Moran (op. cit.) acusam uma notória simplificação de conteúdo nos livros didáticos e o uso da Estatística como fim em exercícios de Matemática, concluindo que aquela não aparece como estratégia para solução de problemas de pesquisa, como deveria ser trabalhada em todos os níveis de ensino. Tomando por base essas constatações, podemos afirmar que, nos últimos 10 anos, ocorreu um avanço quanto ao tratamento dado à Educação Estatística nos livros didáticos do Ensino Fundamental, ao menos na coleção analisada. É possível notar um aperfeiçoamento quanto ao descompasso, apontado pelas autoras, entre os objetivos a serem alcançados com a inclusão do ensino de Estatística e Probabilidade no Ensino Fundamental e a efetivação das propostas nos livros didáticos, principalmente no que se refere à simplificação de conteúdo, ao uso adequado de termos e conceitos estatísticos, bem como quanto à redução da estatística como cálculos matemáticos: percebe-se uma preocupação (ainda que em alguns momentos equivocada) em conceber a Estatística como estratégia de solução de problemas de pesquisa, associando-a à metodologia de resolução de problemas.

\footnotetext{
${ }^{20}$ IEZZI, G.; DOLCE, O.; MACHADO, A. Matemática e Realidade. 5. ed. São Paulo: Atual, 2005.
} 
No entanto, podemos considerar que os problemas propostos apresentam características que comprometem o desenvolvimento do raciocínio estatístico. Em muitos casos, priorizam-se os cálculos matemáticos, deixando em segundo plano os aspectos que, de fato, manifestam interesse. De nada adianta saber calcular média, moda e mediana, sem que se dê o devido tratamento quanto à significância e representatividade de cada uma dessas medidas de tendência central. Assim, apesar de notarmos uma discreta preocupação em se explicitarem essas particularidades no decorrer do texto, as atividades propostas remetem a cálculos, sem nenhuma preocupação com os significados de tais medidas.

Acreditamos que as atividades, na forma como estão apresentadas nos livros didáticos, não possibilitam aos alunos experienciarem situações que envolvam o raciocínio estatístico, visto que, além de, em alguns casos, se demonstrarem prontas, em outros, podem não ser significativas para os alunos. Afinal, elas limitam-se ao aspecto formal da Matemática, comprometendo a construção autônoma e a participação efetiva do aprendiz na elaboração de seu conhecimento e sua tomada de consciência. Muitas das situações ali apresentadas poderiam/deveriam ser potencializadas por meio de experiências concretas de vivência pelos alunos de atividades exploratórias de coleta, organização, apresentação e interpretação de dados reais.

No que concerne a representações gráficas, especificamente, as constatações de Lopes e Moran (1999) continuam a ser evidenciadas. Não se trabalha a organização de dados por meio do ramos-e-folhas ${ }^{21}$, que é uma representação gráfica fácil, simples e elegante, que, não só requer menos conhecimentos anteriores, como permite a introdução dos conceitos de moda e mediana. Além disso, constatamos também a não integração entre conceitos matemáticos e estatísticos, na medida em que diagramas de barras, setoriais, poligonais e histogramas são ricos para explorar relações com áreas, conceitos geométricos (ângulos, formas e escalas) e aritméticos (porcentagem, razão e proporção).

Essa constatação vai ao encontro da afirmação de Lopes e Coutinho de que muitos autores de livros didáticos têm enfocado unicamente a construção e leitura de tabelas e gráficos. Além disso,

[...] a leitura dos gráficos limita-se a uma leitura dos eixos para responder questões específicas, sem a preocupação de levar o aluno a uma interpretação do que efetivamente foi representado naquele gráfico, em termos de variação em um conjunto de dados (LOPES; COUTINHO, 2009, p. 61).

\footnotetext{
${ }^{21}$ Técnica alternativa para organização e apresentação de grupos pequenos de dados quantitativos. A obtenção do diagrama é rápida e fácil. No diagrama de ramos-e-folhas, cada dado é separado em duas partes: Ramo, que é a parte da esquerda e Folhas, a parte da direita. Em seguida, as folhas são colocadas em seus respectivos ramos.
} 
Quanto aos conteúdos, a coleção de livros didáticos analisada atende ao estabelecido nos PCN, que assim os distribui:

- 5 $\mathbf{5}^{\mathbf{a}}$ série: porcentagem e princípios de uma pesquisa estatística (coleta de dados, tabela e gráficos de colunas, escala);

- $\mathbf{6}^{\mathbf{a}}$ série: construção e interpretação de gráficos (colunas, barras, setores e linhas);

- $7^{a}$ série: medidas estatísticas (média aritmética, média ponderada, média geométrica, média a partir de uma tabela de frequências, moda e mediana).

- $\mathbf{8}^{\mathrm{a}}$ série: distribuição de frequência, população, variáveis discretas, contínuas, e qualitativas, média, mediana e moda, medidas de dispersão, princípio fundamental da contagem e princípio de probabilidade.

Contudo, tanto nossa avaliação, como as constatações de Lopes e Moran (1999), comprovam que o mais grave problema evidenciado na análise dos livros didáticos consiste no abandono da Estocástica no Ensino Fundamental. Em nenhum momento encontramos a Probabilidade e a Estatística tratadas de forma associada, principalmente, no âmbito do acaso nas relações estatísticas, aspecto fundamental para a compreensão da diferença entre Matemática e Estatística.

A indeterminação ou a incerteza dos dados distingue uma investigação estatística de
uma exploraçâo matemática, que tem uma natureza mais precisa: os conceitos e os
procedimentos matemáticos são usados como ferramentas para resolver os
problemas estatísticos, mas estes não são limitados por eles; o fundamental nos
problemas estatísticos é que, pela sua natureza, não têm uma solução única e não
podem ser avaliados como totalmente errados nem certos, devendo ser avaliados em
termos da qualidade do raciocínio, da adequação dos métodos utilizados à natureza
dos dados existentes (LOPES; COUTINHO, 2009, p. 67).

Talvez esse seja o equívoco a ser superado nas propostas dos livros didáticos (e das diversas metodologias e atividades desenvolvidas no contexto de sala de aula), para que possamos alcançar os objetivos ressaltados pela proposta curricular brasileira. A variabilidade e o acaso devem ser concebidos como princípios fundamentais para o ensino de Estatística, em todos os níveis de ensino. 


\subsection{Avaliações: Sistema de Avaliação de Rendimento Escolar do Estado de São Paulo (Saresp)}

O Saresp foi criado em meados da década de 90 e, desde então, vem avaliando os alunos das diferentes séries da rede pública de ensino paulista, buscando identificar fatores que interferem no seu rendimento.

Até 2009, foram realizadas dez edições do Saresp, conforme o Quadro 3, cujas células com preenchimento indicam as séries avaliadas em cada um dos anos. De 1996 a 1998 a prova foi aplicada no início do ano, avaliando as séries anteriores (avaliação de entrada) e, nos demais anos, no final do ano (avaliação de saída).

Quadro 3: Realização do Saresp

\begin{tabular}{|c|c|c|c|c|c|c|c|c|c|c|c|}
\hline \multirow{3}{*}{ Ano } & \multicolumn{11}{|c|}{ Séries } \\
\hline & \multicolumn{8}{|c|}{ Ensino Fundamental } & \multicolumn{3}{|c|}{ Ensino Médio } \\
\hline & $\mathbf{1}^{\mathrm{a}}$ & $2^{\mathbf{a}}$ & $3^{a}$ & $4^{a}$ & $5^{a}$ & $6^{a}$ & $7^{a}$ & $8^{a}$ & $\mathbf{1}^{\mathrm{a}}$ & $2^{a}$ & $3^{\mathbf{a}}$ \\
\hline \multicolumn{12}{|l|}{1996} \\
\hline \multicolumn{12}{|l|}{1997} \\
\hline \multicolumn{12}{|l|}{1998} \\
\hline \multicolumn{12}{|l|}{2000} \\
\hline \multicolumn{12}{|l|}{2001} \\
\hline \multicolumn{12}{|l|}{2002} \\
\hline \multicolumn{12}{|l|}{2003} \\
\hline \multicolumn{12}{|l|}{2004} \\
\hline \multicolumn{12}{|l|}{2005} \\
\hline 2007 & & & & & & & & & & & \\
\hline
\end{tabular}

O principal objetivo do Saresp é obter indicadores que possam fundamentar propostas de intervenção e modificações na estrutura educacional, bem como subsidiar propostas de formação continuada para os profissionais da rede estadual. Portanto, a partir de seus resultados, a SEESP fundamenta propostas e ações objetivando o desenvolvimento e a melhoria da qualidade do ensino público paulista, bem como o planejamento escolar e as metas a serem atingidas. A participação é compulsória às escolas estaduais e facultativa às redes municipais e privadas de ensino.

Até o ano de 2004, as provas do Saresp avaliavam a leitura, a escrita e a interpretação de textos. Na edição de 2004, foram incluídas, nas provas dos $3^{\circ}$ e $4^{\circ}$ anos do EF, três questões que envolviam interpretação de gráficos. Somente a partir de 2005, o Saresp passou a avaliar Língua Portuguesa e Matemática, com questões pautadas nos PCN. Os 
resultados são apresentados na mesma escala de desempenho do Sistema de Avaliação da Educação Básica (Saeb), promovido pelo governo federal.

Em que pesem os objetivos acima descritos e apresentados nos documentos de concepção do Saresp, Maruci salienta que

\begin{abstract}
A avaliação educacional de sistemas e sua expansão no Brasil nas últimas décadas tem sido uma resposta à necessidade do Estado de controlar a educação e de prestar contas sobre os financiamentos das políticas educacionais, muitos deles realizados por agências internacionais (BIRD - Banco Internacional de Reconstrução e Desenvolvimento; Banco Mundial) (2007, p. 2).
\end{abstract}

Pestana (1998) adverte, ainda, que as matrizes de referência para as avaliações devem dar transparência ao processo de avaliação e diminuir um de seus maiores riscos, qual seja, a redução daquilo que é ensinado ao que é avaliado.

Uma última consideração se faz necessária, indo ao encontro das constatações de Torino e Mendes (2009), acerca dos objetivos traçados e da implementação das propostas para atingir esses objetivos. O Saresp tem como finalidade avaliar e acompanhar o conhecimento adquirido pelos alunos, visando a fornecer subsídios às políticas de formação continuada, aos professores e aos próprios alunos, quanto ao sistema educacional do Estado de São Paulo. Entretanto, a partir de 2007, os resultados publicados não contemplam todas as questões (apenas as médias por escola e alguns exemplos de questões), impossibilitando ações pontuais, por exemplo, direcionadas aos fatores mais deficitários.

Ainda é um desafio apresentar resultados educacionais de uma forma compreensível
para os gestores escolares, professores e demais membros da comunidade e, além
disso, o Saresp não tem seus resultados disponíveis ao público geral, excetuando o
Saresp de 2007, onde há apenas dois exemplos em cada nível e, assim, não
contempla todas as questões (TORINO; MENDES, 2007, p. 5).

Levando em consideração tal recorte, escolhemos os resultados do Saresp de 2005 da Escola A para fazer uma análise do desempenho dos alunos quanto às questões da prova da $8^{\mathrm{a}}$ série do EF, que envolveram Probabilidade e Estatística. 


\subsubsection{Desempenho dos Alunos no Saresp 2005}

Considerando as informações apresentadas acima, realizamos um levantamento dos conteúdos abordados nas provas da $8^{\mathrm{a}}$ série do EF do Saresp $2005^{22}$, bem como uma análise do desempenho dos alunos da Escola A. A figura abaixo explicita o desempenho dos alunos nos conteúdos e habilidades avaliados nas questões da prova do Saresp do ano de 2005, que abordavam conceitos relacionados ao Tratamento da Informação.
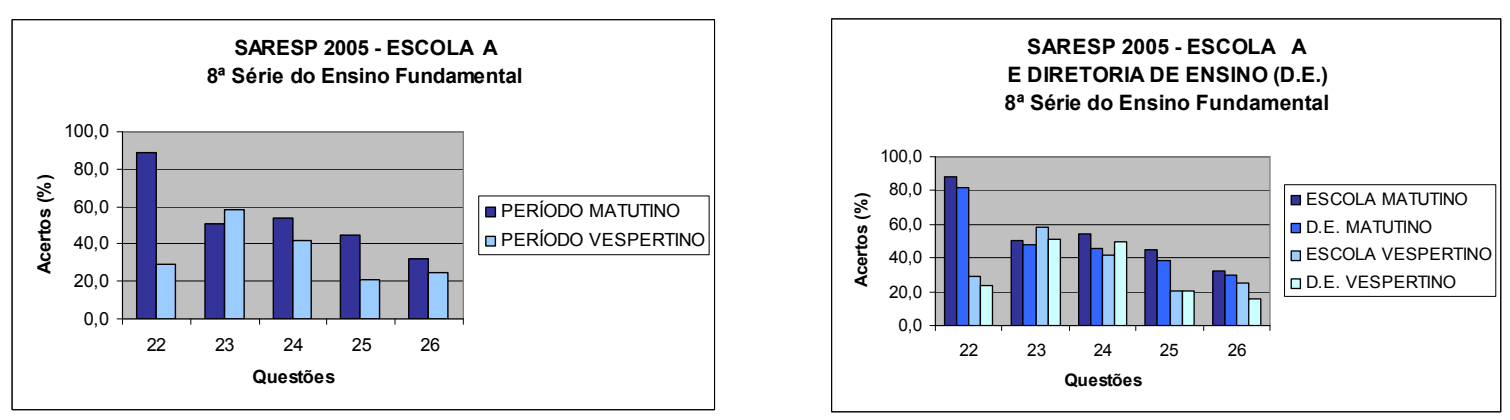

Figura 2: Resultados obtidos pela Escola A no Saresp 2005

As questões cujos resultados/desempenhos obtidos estão apresentados acima avaliaram a capacidade dos alunos acerca dos seguintes aspectos e habilidades: - associar um gráfico (colunas ou linhas) a uma tabela de dupla entrada (Questão 22); - resolver situaçãoproblema, cujos dados estejam apresentados em gráficos, histogramas ou em polígonos de frequência (Questão 23); - usar a distribuição de frequências de uma variável de uma pesquisa em classes de modo a resumir os dados com um grau de precisão razoável (Questão 24); obter medidas de tendência central de uma pesquisa como média e mediana e as interpretar (dados não agrupados em classes) (Questão 25); - indicar a probabilidade de um evento equiprovável por meio de uma razão (Questão 26), conforme consta do ANEXO 1.

Quando se analisa o desempenho na avaliação do Saresp 2005, é clara a dificuldade dos alunos em lidar com conceitos estatísticos e probabilísticos, porque a média de desempenho está em torno de 40\%. Lopes (1998) confirmou que o simples trabalho com gráficos, tabelas e medidas de posição não é suficiente para o desenvolvimento das necessidades básicas dos aprendizes, na medida em que a Probabilidade e a Estatística têm um papel essencial na formação do cidadão. Como proposta de mudança, a autora sugere um trabalho pedagógico que evidencie um ensino de Matemática voltado à realidade do

\footnotetext{
${ }^{22}$ Utilizamos os dados de 2005, porque no ano de 2007 não foram divulgados os resultados obtidos em cada uma das questões.
} 
estudante, centrado na resolução de situações problema contextualizadas e significativas para o aluno.

Foi possível, ainda, identificar intensa dificuldade (menor índice de acertos) nas questões que trabalhavam dados contínuos, envolvendo representação destes em histogramas, em classes modais, bem como a interpretação de medidas de tendência central. Lopes e Moran (1999) avaliam que essa dificuldade pode estar relacionada à forma com que os livros didáticos e, consequentemente, os professores que fazem uso deles, tratam esses conteúdos. Os livros didáticos não fazem a devida abordagem aos dados discretos associandoos a outros conceitos matemáticos como porcentagem, área e plano cartesiano. Além disso, representam variáveis contínuas por meio de gráficos de barras (e não histogramas), de forma a distorcer o conceito de continuidade (ininterrupto). Por fim, atribuem importância, quase que exclusiva, à média como medida de tendência central representativa, quando na verdade sabemos que, como a maioria dos fenômenos não se comportam com regularidade gaussiana $^{23}$, essa subestimação à representatividade das medidas de moda e mediana é um total equívoco.

O desempenho também foi crítico na questão que abordou conceitos relacionados à probabilidade. Coutinho (2001) mostrou em seu trabalho que é fundamental a identificação do contexto no qual o acaso está presente para que se possa construir o significado do valor de probabilidade atribuído ao evento em estudo. Como possível atividade em sala de aula, a autora propõe um raciocínio de modelagem para o qual a avaliação de uma probabilidade simples em uma situação de sucesso-fracasso é feita a partir da análise da urna de Bernoulli, que representa essa situação (contexto de sorteio aleatório com reposição em uma população pré-determinada), de forma a permitir a transposição de uma constatação experimental para a formalização algébrica do conceito.

A questão 23, que solicitou a interpretação de dados contínuos em um gráfico de linhas, apontou que aproximadamente $50 \%$ dos alunos conseguem retirar informações de forma coerente desse tipo de representação. Quando avaliada a mesma competência de realizar a interpretação e análise de dados contínuos, porém, a partir de uma tabela (questão 24), esses índices são um pouco menores, ficando abaixo de 50\%. Ambas as questões evidenciam dificuldades dos alunos em realizar interpretações e análises simples a partir de dados representados em gráficos e tabelas.

\footnotetext{
${ }^{23}$ De acordo com a curva de Gauss (em forma de sino), isto é, com valores muito frequentes em torno da média, diminuindo essa frequência simetricamente à medida que nos afastamos dela.
} 
Na única questão que abordou, de forma simplificada, a leitura e interpretação de gráficos e tabelas de dados discretos (questão 22), na média, houve desempenho melhor (em torno de 60\%). Todavia, essa questão foi a única que apresentou discrepância significativa nos resultados obtidos pelos alunos do período matutino, quando comparados ao vespertino, tanto na escola em questão, quanto na Diretoria de Ensino (DE). Em decorrência disso, o período vespertino obteve um resultado médio (tanto na Escola A quanto na DE) de $30 \%$ de acerto, índice preocupante, tendo em vista a importância das habilidades e conceitos avaliados para a Educação Estatística.

\subsection{Prova Brasil}

A Prova Brasil integra o Sistema Nacional de Avaliação da Educação Básica (Saeb), realizado pelo Instituto Nacional de Estudos e Pesquisas Educacionais Anísio Teixeira (Inep) do Ministério da Educação (MEC), e abrange estudantes das redes públicas e privadas do país, localizados em área rural e urbana, matriculados na $4^{\mathrm{a}}$ e $8^{\mathrm{a}}$ séries $\left(5^{\circ}\right.$ e $9^{\circ}$ anos) do Ensino Fundamental e também no $3^{\circ}$ ano do Ensino Médio. São aplicadas provas de Língua Portuguesa e Matemática.

A avaliação é censitária para alunos de $4^{\mathrm{a}}$ e $8^{\mathrm{a}}$ séries do EF público, nas redes estaduais, municipais e federais, em escolas que tenham no mínimo 20 alunos matriculados na série avaliada. Nesse estrato, a prova recebe o nome de Prova Brasil e oferece resultados por escola, município, unidade da Federação e país.

Em Matemática, o foco da avaliação é a resolução de problemas, sendo avaliadas habilidades e competências definidas em unidades chamadas descritores, agrupadas em temas que compõem a Matriz de Referência dessa disciplina.

As matrizes de Matemática da Prova Brasil e do Saeb estão estruturadas em duas dimensões. Na primeira, que é "objeto do conhecimento", foram elencados seis tópicos, relacionados a habilidades desenvolvidas pelos estudantes. Na segunda, a dimensão da matriz de Matemática refere-se às "competências" desenvolvidas pelos estudantes. Dentro desta perspectiva, foram elaborados descritores específicos para cada um dos quatro tópicos.

No bloco Tratamento da Informação para a $8^{\mathrm{a}}$ série, existem dois descritores:

$\rightarrow$ Resolver problema envolvendo informações apresentadas em tabelas e/ou gráficos.

Esse descritor deve verificar a habilidade de o aluno analisar tabelas ou gráficos, extraindo deles as informações necessárias para a solução do problema. Essa 
habilidade é avaliada por meio de situações-problema contextualizadas, nas quais o aluno deve analisar os gráficos que lhe forem apresentados e possivelmente realizar algum cálculo para obter a resposta do problema.

\section{$\rightarrow \quad$ Associar informações apresentadas em listas e/ou tabelas simples} aos gráficos que as representam e vice-versa.

Esse descritor deve verificar a habilidade de o aluno relacionar informações apresentadas em tabelas com gráficos, ou informações apresentadas em gráficos com tabelas. Essa habilidade é avaliada por meio de situações-problema contextualizadas, nas quais seja possível associar dados apresentados em tabelas, listas, ou quadros a diferentes tipos de gráficos, ou seja, podem ser apresentados gráficos de setor (tipo pizza), gráficos em colunas e gráficos de linhas.

De acordo com esses descritores, são estabelecidos níveis de proficiência, cuja escala de proficiência em Matemática para a $8^{\mathrm{a}}$ série do EF é composta de 14 níveis, iniciando no nível 0 até o nível 13, de acordo com as informações apresentadas na Quadro 4. Trata-se de níveis cumulativos, nos quais se espera que o aluno concluinte do EF tenha atingido o nível 13.

Os resultados obtidos nessa avaliação, no período de 10 anos (1995 a 2005), disponibilizados pelo Inep/MEC, apontam para um aumento de mais de 10\% no índice dos alunos até o nível 5 da escala. Em 1995, tínhamos 48,45\% dos alunos entre os níveis 0 e 5 e, em $2005,60,57 \%$. Se pensarmos que as crianças que se encontram nessa faixa não são capazes de reconhecer um gráfico de colunas correspondente a dados apresentados de forma textual (nível 6), identificar um gráfico de colunas correspondente a um gráfico de setores (nível 6), relacionar frações com representação decimal (nível 7), transformar frações em porcentagens (nível 8), reconhecer e trabalhar com escalas (nível 9), ler, analisar e comparar gráficos (coluna e linha) em um sistema cartesiano (nível 9), obter a média aritmética de um conjunto de valores e analisar um gráfico de linhas com sequência de valores (nível 10), fortalecem-se as dificuldades que o sistema educacional vem enfrentando, particularmente, no contexto da Educação Estatística. 
Quadro 4: Níveis de proficiência em Matemática na Prova Brasil para a $8^{\mathrm{a}}$ série do Ensino Fundamental

\begin{tabular}{|c|c|c|}
\hline Nível & Início da Escala & Término da Escala \\
\hline 0 & 0 & 125 \\
\hline 1 & 125 & 150 \\
\hline 2 & 150 & 175 \\
\hline 3 & 175 & 200 \\
\hline 4 & 200 & 225 \\
\hline 5 & 225 & 250 \\
\hline 6 & 250 & 275 \\
\hline 7 & 275 & 300 \\
\hline 8 & 300 & 325 \\
\hline 9 & 325 & 350 \\
\hline 10 & 350 & 375 \\
\hline 11 & 375 & 400 \\
\hline 12 & 400 & 425 \\
\hline 13 & \multicolumn{2}{|l}{425 ou mais } \\
\hline
\end{tabular}

Fonte: Inep/MEC

Os resultados na Prova Brasil do ano de 2007 apontam que a média de desempenho em Matemática, em nível nacional, é de 240,56, portanto, no nível 5 da escala. Os índices obtidos pela escola em que realizamos este trabalho são um pouco superiores, atingindo o nível 6 da escala de Matemática $(266,79)$. Ainda assim, conjecturamos que muitos dos conceitos fundamentais para o desenvolvimento da Literacia Estatística estão comprometidos e necessitam de um tratamento mais adequado.

\subsection{Avaliação Diagnóstica}

Com o objetivo de analisar o ensino atual, as condições dos alunos, bem como os entraves e dificuldades relacionados com a leitura e interpretação de gráficos, pautados no trabalho de Curcio (1987), elaboramos, a partir de gráficos e informações encontradas em diversas mídias (jornais, revistas, internet), três atividades diagnósticas envolvendo gráficos de linha, de barra e de setores, respectivamente (APÊNDICE A). As referidas atividades compunham-se de 06 ou 07 questões de múltipla escolha, propondo três tarefas de compreensão:

- duas questões abordando aspectos literais (que exigem uma leitura literal dos dados, títulos ou rótulos para "ler os dados");

- duas (ou três, dependendo da atividade) questões relacionadas à habilidade de comparação de itens (que requerem a utilização de comparações e conceitos matemáticos para "ler entre os dados"); e 
- duas (ou três, dependendo da atividade) questões abordando itens de extensão (que exige uma extensão, uma previsão, ou inferência para "ler além dos dados").

Cada uma das atividades foi acompanhada de um Inventário de Conhecimentos Prévios, também composto de 06 ou 07 questões, considerando as três dimensões que, segundo Curcio (1987), podem influenciar na capacidade de leitura e interpretação de gráficos: tema, conteúdo matemático e forma gráfica. O inventário foi elaborado de forma a coincidir com o tema, conteúdo matemático e forma gráfica de cada uma das três atividades de diagnóstico.

Os resultados dos questionários respondidos pelos alunos de uma $8^{\mathrm{a}}$ série do $\mathrm{EF}$, sujeitos da pesquisa, apontam que os alunos vivem muitas dificuldades em conceitos matemáticos básicos, como conjuntos/subconjuntos numéricos, porcentagem, razão e proporção e ângulos (APÊNDICE B). Além disso, a leitura de informações apresentadas nos gráficos é precária. Os resultados obtidos com a atividade envolvendo gráfico de linhas demonstraram que $40 \%$ dos alunos não são capazes de realizar, nem mesmo, sua leitura pontual (indicação do maior índice, por exemplo). Quando analisamos a capacidade de identificação da variação dos dados num intervalo, este índice também é semelhante. Quanto ao gráfico de barras, mais de 70\% dos alunos não conseguiram identificar um intervalo menor que determinado valor e aproximadamente $85 \%$ não foram capazes de quantificar a diferença existente entre os dados apresentados em duas barras distintas. Quanto ao gráfico de setores, constatamos que a análise é feita de forma superficial, considerando apenas o "tamanho" de cada uma das partes, sem a utilização de uma comparação proporcional entre as porcentagens representadas em cada setor. Finalmente, ao estudarmos as questões que envolviam uma análise além dos dados, visando à inferência de algumas relações e/ou conclusões, os resultados apontaram que, nas três atividades, aproximadamente $90 \%$ dos alunos não foram capazes de realizar esse tipo de raciocínio. 


\subsection{Considerações acerca das Análises Preliminares}

Os PCN para o terceiro e quarto ciclos do EF dispõem que o Tratamento da Informação deve ser desenvolvido por meio da exploração de situações que envolvam coleta, organização e análise de informações, construção e interpretação de tabelas e gráficos, formulação de argumentos convincentes fundamentados nas representações matemáticas e princípios de Probabilidade e Combinatória.

Analisando a PCSP, podemos afirmar que o documento atribui relevante importância à Estatística na formação escolar, considerando que sua utilização viabiliza o desenvolvimento da interpretação, reflexão e aplicação de conceitos matemáticos ao cotidiano, tornando essa ciência mais significativa e próxima do aprendiz. Além disso, o documento salienta que a representação de dados e o Tratamento da Informação podem abrir espaço para a incorporação crítica das TIC no ensino. Incoerentemente, as atividades propostas nos cadernos não atingem o contexto dos alunos, bem como (em alguns casos) caracterizam um reducionismo da Estatística com visão utilitarista e tecnicista. Além disso, os conteúdos de Estatística (apesar de relacionarem diversos outros conceitos e habilidades matemáticas) são tratados nos últimos bimestres, por meio de restritas atividades.

Considerando como parâmetros comparativos, o trabalho de Lopes e Moran (1999) e a análise da coleção de livros didáticos utilizados pela escola em que realizamos o trabalho, constatamos que esse material apresenta atividades e conteúdos bastante interessantes e abrangentes, ainda que não se preocupem com os princípios de variabilidade e significância amostral, comprometendo, dessa forma, as inferências que os alunos venham a fazer. As atividades também podem ser limitadas pela forma como são trabalhadas e por não caracterizarem, em muitos momentos, problemas pertinentes para os alunos.

Os resultados do Saresp 2005 evidenciam muitas dificuldades quanto às habilidades avaliadas no contexto do Tratamento da Informação, na medida em que a média de acertos nas questões que cobravam a leitura e interpretação de gráficos e tabelas girou em torno de $40 \%$ na Escola A.

Os índices de desempenho na Prova Brasil, tanto em nível nacional como na Escola A, também ratificam as constatações do Saresp, apontando que os alunos atingem os níveis 5 e 6 da escala de desempenho em Matemática, os quais esclarecem dificuldades em trabalhar com os números decimais e suas representações fracionárias e percentuais. Além disso, enfatizam as deficiências de interpretação e relacionamento de informações 
apresentadas em gráficos de colunas, bem como as de compreensão e de trabalho com dados proporcionais e escalas.

$\mathrm{O}$ instrumento diagnóstico mostrou-nos em termos estruturais - e entre os gráficos analisados - que os alunos encontram maior dificuldade em analisar os gráficos de linhas, talvez por envolver dados contínuos (não categóricos).

Os conceitos matemáticos fundamentais para leituras gráficas - conjuntos numéricos, porcentagem, proporção e ângulos - evidenciam índices de acertos muito preocupantes (alguns próximos de zero), caracterizando problemas de aprendizagem de conceitos fundamentais, não só para a Estatística, mas para a Álgebra e Aritmética.

Da mesma forma, os estudantes não conseguem comparar dados apresentados em gráficos e não retiram conclusões a partir deles.

Finalmente, acreditamos que os pressupostos apontados por Curcio (1987) trouxeram contribuições muito significativas e adequadas ao trabalho, na medida em que evidenciaram que muitos dos problemas estatísticos podem estar relacionados a não apropriação de conceitos matemáticos, necessários para a devida leitura de uma representação gráfica. Nesse contexto, constata-se a importância e a relevância de se integrar o Tratamento da Informação a outros conceitos da Aritmética, Álgebra e Geometria, visando a estabelecer as devidas relações existentes entre as diversas áreas da Matemática, na direção de possibilitar aplicações práticas de conceitos abstratos. Um exemplo disso é a utilização dos conceitos de círculo, setor circular, ângulo, proporção e porcentagem para explicar as relações existentes e necessárias à adequada leitura e interpretação de um gráfico de setores. 


\section{CONCEPÇÃO E ANÁLISE $A$ PRIORI DA SEQUÊNCIA DIDÁTICA}

Segundo a Engenharia Didática, esta fase consiste na preparação da sequência didática e do esquema experimental para a ação em sala de aula, quando devem ser delimitadas variáveis de controle que possibilitem conhecer o que se pretende experimentar. $\mathrm{Na}$ execução desta pesquisa, trata-se do processo de construção e elaboração de uma sequência didática na concepção de Zabala (1998) e segundo os pressupostos da Teoria das Situações Didáticas de Brousseau e da de Registros de Representação Semiótica de Duval, a partir da compreensão de Educação Estatística, apresentada na introdução deste trabalho. $\mathrm{O}$ último fundamento abre-nos a possibilidade de tomar o Guidelines for Assessment and Instruction in Statistics Education (GAISE) Report: a Pré-K-12 Curriculum Framework (ASA, 2005), em conjunto com as orientações presentes nos PCN e na PCSP, como direcionador das ações.

\subsection{Fundamento Conceitual para a Sequência: o GAISE}

A partir da estrutura conceitual do GAISE, demonstrada no Quadro 1, e diante da complexidade que a envolve, fazemos uma leitura e contextualização desses princípios e orientações para fundamentar nossas atividades.

Esse recorte é representado no esquema da Figura 3 onde podem ser encontradas as idéias transpostas das orientações do GAISE que fundamentaram a concepção da sequência didática ora discutida. 


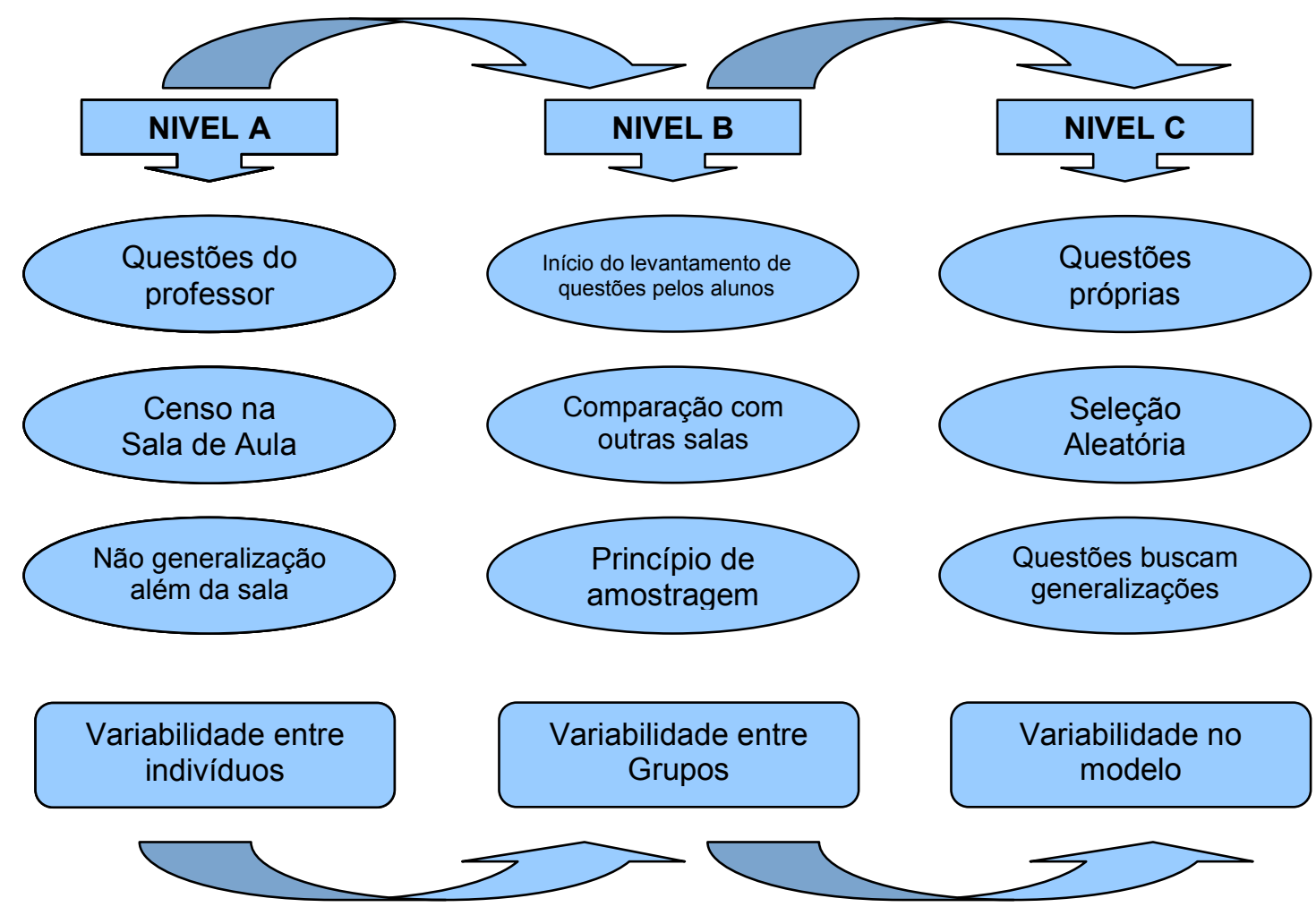

Figura 3: Princípios da GAISE que fundamentarão a sequência didática

De acordo com o esquema anterior, as atividades visaram à construção da idéia de variabilidade, a partir de experiências reais, que evidenciaram as diversas naturezas dessa variabilidade no contexto de uma investigação estatística. Iniciamos as atividades no nível A, com questões propostas pelo professor/pesquisador, limitado a um censo na sala de aula sem objetivos de generalização. Com esse trabalho interno à $8^{\mathrm{a}}$ série $\mathrm{X}$, esperamos que os alunos pudessem compreender a variabilidade entre indivíduos. Passamos ao nível $\mathrm{B}$, quando pretendíamos que os alunos conjecturassem algumas questões, realizando comparações com outras salas. Com essas atividades, eles puderam perceber a variabilidade existente entre grupos diferentes, facilitando a introdução do princípio de amostragem. Atingindo o nível C, provocações foram feitas no sentido de que os alunos pudessem elaborar questões para serem respondidas por meio de uma investigação estatística. Compreendidas as variabilidades entre indivíduos e entre grupos, tornou-se possível a compreensão de seleção aleatória, visando a minimizar os erros amostrais, possibilitando a realização de análises com questões que buscaram generalizações. Esses foram os princípios do GAISE que fundamentaram a sequência didática explicitada a seguir. 


\subsection{Estruturação das Situações Didáticas}

De acordo com os princípios apresentados até aqui, elaboramos a ordenação das atividades da sequência. Cabe salientar que ela priorizou o desenvolvimento da Literacia Estatística por meio do raciocínio e das ideias, pretendendo romper com a visão instrumental e mecanicista "segundo a qual a Estatística é um conjunto de noções e técnicas matemáticas rigorosas, que podem utilizar forma objetiva, estando a atividade estatística circunscrita a uma utilização formal e mecanicista dessas noções e técnicas" (LOPES; CARVALHO; 2009, p. 78).

É preciso propiciar um espaço pedagógico que valorize o processo ao invés do fato, as ideias ao invés das técnicas; que proponha uma grande diversidade de problemas envolvendo outras áreas ou mesmo áreas internas da própria Matemática (LOPES, 1998). Trata-se de ressaltar o aspecto variável, princípio que fundamenta as atividades estatísticas.

Essa nos parece uma questão central quando queremos pensar a abordagem da estatística nas aulas de Matemática, pois a resolução de problemas em Estatística depende do entendimento, da explicitação e da quantificação da variabilidade nos dados (LOPES, 2008a, p.69).

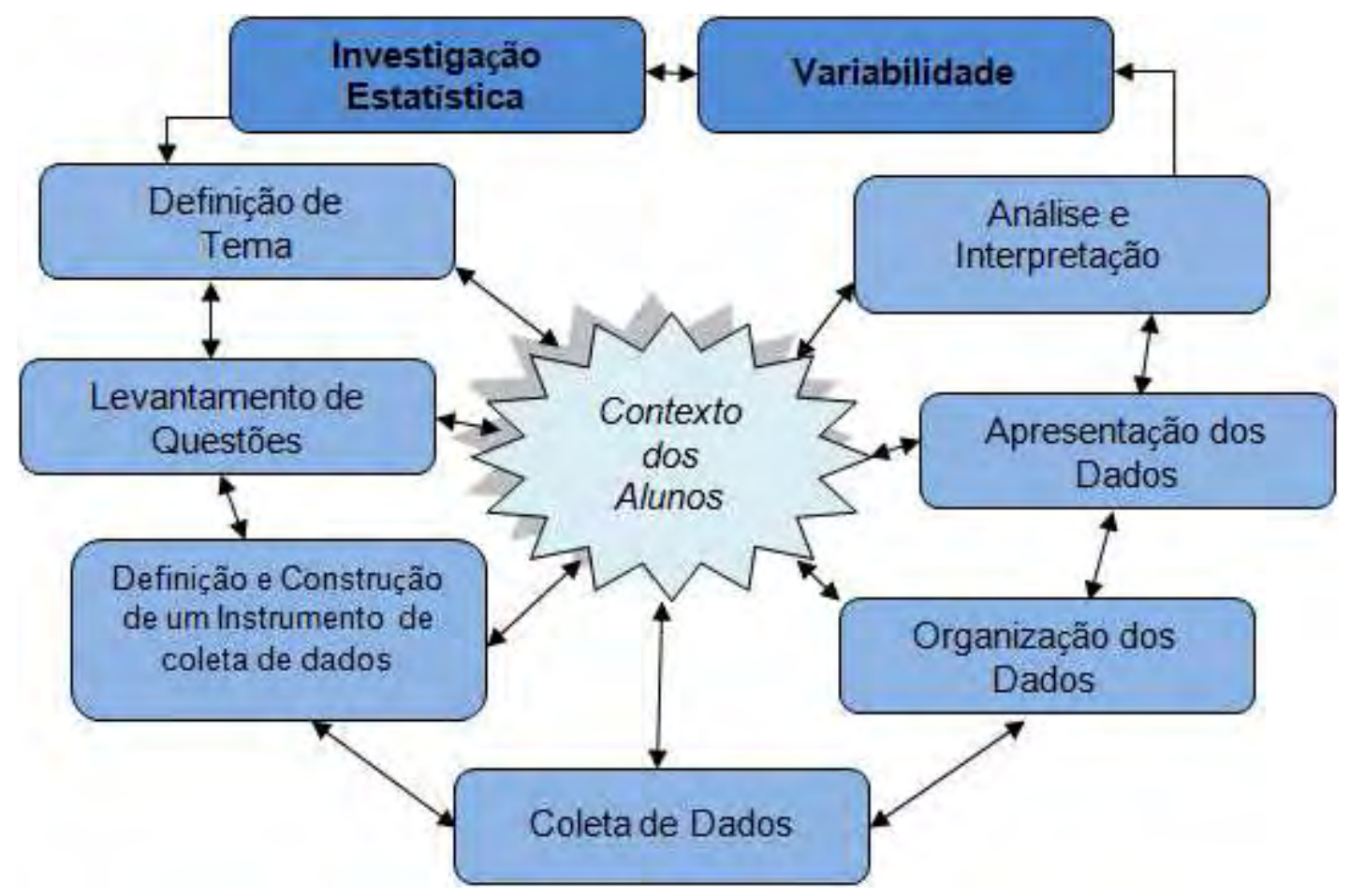

Figura 4: Estrutura da Sequência Didática

A Figura 4 esclarece um esquema, que representa as etapas da Sequência Didática, a partir do princípio de compreensão da natureza a variabiliade e da 
problematização da realidade dos alunos, de modo a facilitar a compreensão das idéias e conceitos envolvidos do processo de investigação estatística.

As discussões de cada uma dessas etapas, de acordo com os princípios do GAISE, da Teoria das Situações Didáticas, da Teoria dos Registros de Representação Semiótica e da compreensão de Educação Estatística no Ensino Fundamental explicitados no segundo capítulo, são apresentadas a seguir.

\title{
4.2.1 Definição de um tema de interesse dos alunos
}

Segundo Batanero (2001), o ponto de início do trabalho estatístico deve proporcionar o encontro dos alunos com dados reais. Além disso, considerando o princípio de variabilidade presente em qualquer investigação estatística, o contexto deve assumir um papel fundamental para a atribuição de significado a resumos e representações estatísticas.

\begin{abstract}
O foco sobre a variabilidade natural dá a estatística um conteúdo específico que é colocado além da própria matemática e de outras ciências matemáticas, mas não é apenas o conteúdo que distingue o pensamento estatístico do matemático. A estatística requer um tipo diferente de pensamento, porque os dados não são apenas números, eles são números com um contexto. Na matemática, o contexto obscurece a estrutura. Na análise de dados, o contexto dá sentido (Cobb e Moore, 1997 apud ASA, 2005, p. 7, tradução nossa).
\end{abstract}

Portanto, a definição de um tema de investigação a partir do interesse e da realidade dos alunos ratifica as afirmações acima e, ao mesmo tempo, contribui para o desenvolvimento da Literacia Estatística, na medida em que proporciona o trabalho com dados significativos, facilitando o processo de tomada de consciência, isto é, rompendo com a visão instrumental da Estatística como ferramenta de cálculos matemáticos, os quais, apesar de se pautarem em registros numéricos, representam muito mais que isso. É preciso uma leitura pormenorizada e global a fim de retirar informações a partir desses dados, proporcionando a criação de uma situação-problema na perspectiva de Pólya, isto é, uma situação favorável à investidura de esforços por parte do aprendiz no sentido de obter uma informação não acessível de maneira imediata (POLYA, 1986). Trata-se da devolutiva tratada na Teoria das Situações Didáticas de Brousseau.

Para Polya (op. cit.), a resolução de um problema significa, na verdade, um desafio e um pouco de descobrimento, uma vez que não existe um método rígido que o aluno possa sempre seguir para encontrar a solução de uma situação-problema. O autor afirma que existem passos que o pensamento necessita percorrer, mais especificamente, os de resolução, que podem ajudar o aluno neste processo, a saber: compreender o problema, estabelecer um 
plano, executar o plano e o retrospecto, que trata da comparação entre a questão inicial e os resultados obtidos para verificar se eles respondem ao problema. De acordo com o GAISE, a resolução de problemas estatísticos perpassa as mesmas etapas, porque parte da formulação de uma questão, seguida pelo estabelecimento e utilização de um plano apropriado para coleta dos dados, realização das análises por meio de métodos gráfico e numérico adequados, finalizando com a interpretação dos resultados, quando se comparam as análises realizadas com a questão inicial.

A partir dessas ideias de Polya (1986) e das orientações do GAISE, podemos fazer uma reescrita dos quatro passos de resolução para melhor entender as situaçõesproblema no contexto de uma investigação exploratória de dados:

\section{$\rightarrow \quad$ Compreensão da situação-problema: esta é a primeira etapa} de resolução em que devemos interpretar o que sugere a situação-problema, retirar o(s) dado(s) relevante(s) nela contida, verificar qual a questão de investigação e o que precisa ser resolvido, em termos de conhecimentos matemáticos. Em nosso caso, trata-se de um processo um pouco mais complexo, na medida em que a situação-problema deverá surgir dos próprios alunos, a partir de uma situação significativa. Algumas questões serão levantadas ${ }^{24}$ de forma a delinear o problema em questão e favorecer o desenvolvimento das etapas seguintes.

$\rightarrow \quad$ Estabelecimento do plano de resolução: esta segunda etapa exige que o aluno faça mentalmente ou por escrito a conexão teoria-prática-problema, em que a teoria são os conhecimentos matemáticos apreendidos anteriormente e ensinados pelo professor; a prática, os conhecimentos obtidos das suas vivências diárias e o problema, os dados obtidos da situação-problema proposta. O aluno deverá reconhecer a necessidade de uma investigação estatística, na medida em que será necessário realizar um levantamento de dados, bem como organizá-los e interpretá-los para buscar as respostas para suas questões. A partir dessa compreensão, um plano para a coleta desses dados, e, posteriormente, organização, análise e interpretação, deverá ser traçado.

$\rightarrow \quad$ Execução do plano: nesta terceira etapa o aluno executará o plano elaborado na etapa anterior, com o propósito de obter a solução da situação-problema. Trata-se do efetivo desenvolvimento da investigação, perpassando todas as suas etapas: coleta, organização, apresentação, análise e interpretação dos dados.

$\rightarrow \quad$ Retrospecto: nesta quarta e última etapa, o aluno verificará se a solução que encontrou é realmente a que foi solicitada pelo enunciado e pela pergunta da

\footnotetext{
${ }^{24}$ Conforme explicitaremos no item 4.2.2.
} 
situação-problema. Aqui, o professor deve ser um agente participante, no sentido de fazer coerentemente as intervenções ao examinar a solução que cada aluno encontrou, se ela é correta ou não. À medida que a solução de um problema estatístico depende necessariamente das questões feitas inicialmente, o papel do professor é analisar a qualidade do raciocínio do aprendiz, no sentido de verificar o nível de apropriação e desenvolvimento do raciocínio estatístico, visando ao nível de letramento científico proposto por Shamos (1995 apud GAL, 2002), bem como a possibilidade de inferências "além dos dados" discutida por Curcio (1987).

\subsubsection{Levantamento de algumas questões}

Delineado o tema de investigação da situação-problema, devendo esse ser de interesse dos alunos e condizente com sua realidade, há a necessidade de se estruturarem questões relacionadas ao tema, que justifiquem a necessidade de se realizar uma investigação estatística.

A formulação de uma questão representa o ponto de partida para qualquer estudo estatístico e a qualidade dos resultados desse estudo depende substancialmente da boa formulação da(s) questão(ões) de investigação. “Os estudantes devem ser capazes de formular questões e determinar como os dados podem ser coletados e analisados para prover uma resposta" (ASA, 2005, p. 61, tradução nossa).

Acreditamos que não há sentido em simplesmente solicitar aos alunos que façam uma pesquisa de campo, organizem os dados em tabelas e gráficos e entreguem ao professor. Há a necessidade de se estabelecer objetivos consistentes para o trabalho estatístico, de forma que alunos e professores tenham clareza disso. Essa constatação vai ao encontro da afirmação de Zabala (1998), de que as intenções educacionais necessitam estar claras para o sucesso de qualquer atividade.

Em termos de resolução de problemas, trata-se da etapa de tomada de consciência da situação e do estabelecimento de uma estratégia para a solução. Em se tratando de uma investigação estatística, fatalmente esse início se dá pelo delineamento de questões que possam ser respondidas por meio dos dados (ASA, 2005). 


\subsubsection{Definição de um instrumento para a coleta de dados}

Segundo o GAISE, a maioria das perguntas que podem ser respondidas através da coleta e interpretação de dados exige um determinado estudo, geralmente uma pesquisa amostral ou um experimento.

Esse dois tipos de investigação estatística apresentam alguns elementos comuns -
ambos requerem aleatoriedade, tanto para fins de reduzir as influências quanto para
construir uma base para a inferência estatística. [...] Mas estes dois tipos de
investigação têm objetivos e necessidades muito diferentes. Os levantamentos por
amostragem são utilizados para estimar ou tomar decisões sobre as características
(parâmetros) das populações. Para um estudo bem definido, fixar a população é o
principal ingrediente. Os experimentos são utilizados para estimar e comparar os
efeitos de diferentes condições experimentais (tratamentos), e exigem tratamentos e
unidades experimentais bem definidos para estudar esses tratamentos (ASA, 2005,
p. 64 , tradução nossa).

No entanto, estudos que não têm seleção aleatória alguma nas amostras ou atribuição aleatória dos tratamentos às unidades experimentais são chamados de estudos observacionais no GAISE. "Um estudo de quantos estudantes em sua escola tem asma e como esta se divide entre os sexos e faixas etárias, seria deste tipo" (ASA, 2005, p. 65, tradução nossa). Neste contexto, acreditamos que, pelo nível de raciocínio e conhecimento estatístico evidenciado nas análises preliminares, este estudo seja o mais adequado visando à familiarização dos aprendizes com a situação de uma investigação estatística.

Por não considerarem a aleatoriedade, estudos observacionais não são passíveis de inferência estatística no sentido habitual do termo, mas eles podem fornecer informações valiosas, de acordo com as questões de investigação (ASA, 2005). Assim, tem origem a necessidade de se estabelecer bons instrumentos para a coleta de dados: normalmente, para estudos estatísticos se opta pelo questionário por se tratar de uma organização de perguntas que deve ser respondida por escrito, o que facilita a organização posteriormente.

Na sequência didática pretendida, o questionário foi construído pelos próprios alunos, sob a orientação do pesquisador/professor que atuou como provocador de questionamentos a respeito das concepções por eles evidenciadas no decorrer das atividades. Assim, os alunos puderam começar a aprender sobre as pesquisas e as muitas armadilhas a se evitar quando se projeta e conduz uma investigação estatística. Além disso, os alunos experienciaram o processo de formulação de perguntas, de forma a perceber que essas devem ser inequívocas e de fácil compreensão (ASA, 2005) e que devem estar alinhadas com os objetivos traçados no momento do delineamento das questões de investigação. "É importante 
que os alunos percebam que as conclusões de seu estudo dependem da precisão dos seus dados" (ASA, 2005, p. 41, tradução nossa).

Por fim, cabe salientar dois aspectos: a estrutura do milieu da situação e os registros de representação utilizados.

O primeiro remete-nos ao fato, mesmo realizando a construção das questões por meio de uma situação adidática, quando os alunos elaboraram as questões sem fins didáticos explícitos, já iniciamos as intencionalidades didáticas criando contrapontos e argumentos que os colocaram no contexto de um milieu antagônico. Trata-se da estruturação da devolutiva, em que o professor contextualiza a situação visando a integrar o aluno a uma situação de investigação, de forma que esse vislumbre possibilidades e conjecture questões que (co)respondam ao seu problema, por meio de conhecimentos já existentes em seu milieu de referência. O professor age como mediador no processo e o aluno passa da situação objetiva para a situação de aprendizagem. Além disso, a interação entre os próprios alunos caracteriza um importante componente social facilitador do processo de resolução de um problema. Segundo Perrin-Glorian, "uma intervenção desse componente - que é normalmente específico do milieu adidático - pode levar a uma mudança no milieu cognitivo dos níveis inferiores, ou seja, na passagem de uma situação para outra" (1998 apud ALMOLOUD, 2007, p. 45). Apesar de caracterizar uma situação adidática, o caráter didático implícito é forte, na medida em que o aluno necessita pensar no processo investigativo como um todo para estabelecer questões que respondam ao problema inicial e possibilitem a análise e interpretação posteriores.

O segundo aspecto trata da iniciação do trabalho com os registros de representação semiótica. Partimos da língua natural, isto é, uma representação discursiva multifuncional, para a estruturação dos questionários, que já utilizam uma estrutura e linguagem formal, podendo caracterizar uma representação discursiva monofuncional. A partir do questionário elaborado, foram construídas tabelas, posteriormente, gráficos e, ao final, apresentadas as conclusões por meio da linguagem escrita. Em resumo, trabalhamos com o mesmo tipo de informação, em diferentes formas de registro, contribuindo para a aprendizagem, tendo em vista que "a compreensão em matemática supõe a coordenação de ao menos dois registros de representação semiótica" (DUVAL, 2003, p. 15) e a abstração do significado de sua representação. 


\subsubsection{Aplicação do instrumento}

Como parte do processo investigativo, a fase de aplicação pode permitir que os alunos percebam a complexidade do processo de coleta dos dados, já que ele envolve diversas variáveis e situações, bem como a necessidade de as questões serem bem estruturadas, tendo em vista que as ambiguidades certamente serão evidenciadas no momento em que o indivíduo investigado responder ao questionário.

Como forma de minimizar esses problemas, a sala foi utilizada como "piloto", de forma que os próprios alunos responderam às questões por eles elaboradas. Considerando que as formas de raciocínio são diferentes, alguns problemas quanto à estrutura das questões foram evidenciados de antemão e o questionário foi melhorado para aplicação com os demais grupos.

Fechada a formulação do questionário de coleta de dados, ele foi aplicado em outros grupos de alunos, a fim de possibilitar a análise comparativa ${ }^{25}$ proposta na investigação.

\subsubsection{Organização dos dados coletados}

Para organização dos dados, os alunos construíram tabelas simples, observando a frequência absoluta e a frequência relativa dos dados, bem como tabelas de dupla entrada, quando se tratava de variáveis determinadas por dois atributos. Com isso, puderam trabalhar o conceito de porcentagem e as habilidades em relacionar as informações dispostas nas linhas e colunas com os títulos horizontais e verticais. Nesse contexto, identificaram a necessidade de se ter uma visão global dos dados ao se organizar e ler uma tabela de dupla entrada. O software Excel foi utilizado para facilitar a organização das tabelas e os cálculos das frequências relativas.

O milieu antagônico foi fundamental nesta situação, já que significou os primeiros processos de transformações de registros de representações semióticas:

$\rightarrow \quad$ conversão: os alunos transformaram todos os dados coletados, por meio do questionário, em um registro tabelar. Tivemos, portanto, a não-congruência, pois são bastante diferentes uma linguagem escrita ou falada e a representação desses dados em uma tabela. Além disso, há que se salientar as frequências relativas calculadas, quando os alunos

\footnotetext{
${ }^{25}$ Conforme explicitaremos no item de análise dos dados.
} 
perceberam que um percentual pode ser escrito com diferentes tipos de registro, por exemplo, $\frac{1}{2}=0,5=50 \%$. Para tanto, o Excel trouxe contribuições, na medida em que possibilitou a configuração para representação do percentual de acordo com a conveniência do usuário.

$\rightarrow \quad$ tratamento: alguns cálculos foram necessários para a totalização dos dados, permanecendo no mesmo sistema.

Além disso, neste momento, o professor encontrou-se num milieu didático e o aluno num milieu de referência de tudo o que já vivenciou e aprendeu até então. O professor necessitou projetar muito bem a atividade para atuar como mediador nas interações entre o milieu de referência e de aprendizagem do aluno, fazendo as provocações e intervenções necessárias para a criação e a manutenção constante de um milieu antagônico que possibilitasse retroações cognitivas do aprendiz, visando ao avanço entre os níveis de desenvolvimento.

\subsubsection{Apresentação dos dados em gráficos}

Organizados os dados em tabelas, passamos à segunda transformação do tipo de registro na sequência didática: transformação das tabelas em gráficos.

Trata-se de mais uma conversão, na qual já ficou evidente (análises preliminares) a dificuldade por parte dos alunos para estabelecer a relação entre os dados apresentados em uma tabela e sua correspondência gráfica.

Os gráficos de colunas e barras demandam os conceitos matemáticos de ordem, de medida e de grandeza e acionam as funções cognitivas de comunicação, de objetivação e de identificação, assim como as tabelas, porque as representações transmitem uma mensagem que utiliza códigos comuns entre indivíduos e, ao mesmo tempo, informam dados antes não conhecidos, facilitando encontrá-los e reencontrá-los (ARAUJO; FLORES, 2007).

Os gráficos de setores demandam conhecimento de Geometria, acionando as mesmas funções cognitivas anteriores.

Tendo em vista as dificuldades dos alunos em trabalhar com dados contínuos, acreditamos que um histograma pode auxiliar na compreensão das particularidades desse tipo de variável, favorecendo a inserção posterior do gráfico de linhas.

Para a construção dos gráficos, utilizamos o software SuperLogo 3.0 que introduzimos no capítulo 2 e contextualizamos na situação didática a seguir. 


\subsubsection{O SuperLogo 3.0 e a construção de gráficos}

A integração do SuperLogo 3.0 ao processo de ensino-aprendizagem visa a propiciar a intervenção do professor e a compreensão do raciocínio do aluno (VALENTE, 1993). Como o aprendiz necessita ensinar a tartaruga para que ela realize os movimentos e construa as figuras na área de trabalho, acreditamos que seja possível criar um milieu de aprendizagem, no qual o professor atua como mediador da situação, intervindo nos momentos em que percebe equívocos e/ou insuficiência dos conhecimentos necessários à construção dos gráficos. Todavia, a intervenção não interfere na autonomia do aluno enquanto construtor de seu conhecimento, haja vista que a própria interação entre os comandos dados à tartaruga e a ação por ela executada possibilita retroações sobre o milieu tornando-o antagônico sempre que não se constata a devida correspondência. Trata-se da espiral da aprendizagem de Valente (2002), durante a qual o aluno descreve os comandos na linha de comandos do SuperLogo e a tartaruga executa-os na janela gráfica. Concomitantemente, ele reflete a respeito dos resultados obtidos e, caso não seja o esperado, procura depurar os erros constatados por meio de seus conhecimentos prévios, realizando uma nova descrição.

Além disso, o trabalho com o SuperLogo 3.0 possibilita o desenvolvimento do raciocínio proporcional, fundamental para a Educação Estatística, visto que possibilita trabalhar com variáveis relacionadas por uma razão, bem como necessita da proporcionalidade para a construção de gráficos de setores.

Segundo Lesh, Post e Behr (1988 apud COSTA, 2007), o raciocínio proporcional é o prioritário dos conceitos aritméticos que servirão de base a futuras aprendizagens, uma vez que envolve conhecimentos algébricos relacionados com equivalências (razões, expressões ou equações equivalentes), variáveis e transformações. Cramer e Post (1993 apud ibidem) consideram o raciocínio proporcional um tema bastante rico, uma vez que permite que se façam vários tipos de conexões, tanto entre diferentes tópicos da Matemática, como também em outras disciplinas de Ciências. Por outro lado, também permite a exploração de vários sistemas de representação como gráficos, tabelas e expressões para a mesma situação. Esse raciocínio está associado à capacidade de fazer análises conscientes da relação entre quantidades, o que se evidencia em argumentos e explicações sobre as relações proporcionais.

O raciocínio proporcional implica, por um lado, a compreensão de uma relação constante entre duas grandezas - invariância - e, por outro lado, a percepção de que estas grandezas estão relacionadas e variam em conjunto - covariância. Ou seja, o raciocínio proporcional implica muito mais do que o simples uso da expressão $\mathrm{a} / \mathrm{b}=$ c/d para resolver problemas (COSTA, 2007, p. 80). 
Neste contexto, o trabalho de construção dos gráficos está fundamentado no raciocínio proporcional de ampliação e redução, que é quando existe uma relação que se deve preservar de um para um (ibidem).

Visando a facilitar a construção dos gráficos, optamos por deixar o procedimento para a construção do eixo elaborado, tendo o aluno a necessidade de determinar algumas variáveis para essa construção.

$\rightarrow$ O tipo de gráfico: cada gráfico necessita de um tipo de eixo específico (exceto o gráfico de setores). Dessa forma, é necessário que o aluno indique o eixo pretendido (eixobarra, eixocoluna, eixohistograma).

$\rightarrow$ A amplitude do eixo numérico (variável 'amplitude'): de acordo com a amplitude dos dados de cada um dos grupos, os alunos determinavam a amplitude necessária para cada um dos gráficos.

$\rightarrow$ A amplitude em passos de tartaruga (variável 'amplitudepassos'): considerando que os passos da tartaruga têm dimensão reduzida, dificultando a visualização do gráfico (por exemplo, se pensarmos num eixo com comprimento de 20 passos de tartaruga), há a necessidade de se estabelecer uma proporção (como se colocássemos uma lente de aumento em nosso eixo) para facilitar a visualização do gráfico. Assim, os alunos foram convidados a multiplicar sua amplitude por um determinado número (razão) para determinar a amplitude do eixo nos passos da tartaruga (por exemplo, multiplicar 20 por 10 e utilizar a razão 1 para 10 na relação entre a amplitude real e a amplitude em passos de tartaruga).

$\rightarrow$ A escala (variável 'escala'): de acordo com a amplitude do eixo, os alunos determinaram a escala em que o eixo numérico seria subdividido, de forma que os intervalos fossem de fácil visualização.

$\rightarrow$ A escala em passos de tartaruga (variável 'escalapassos'): de maneira análoga ao estabelecimento da amplitude em passos de tartaruga, os alunos necessitaram estabelecer a mesma proporção para fazer a divisão das escalas, de acordo com os passos de tartaruga.

Dessa forma, foi necessário trabalhar constantemente com o raciocínio proporcional, desde a construção dos eixos, até a construção das barras e colunas que constituíam cada um dos gráficos, sempre pensando na razão estabelecida inicialmente. A 
partir desses eixos, tendo como origem $(0,0)$ o centro da tela do computador (posição $(0,0)$ ), os alunos puderam traçar gráficos. Abaixo apresentamos a descrição dos procedimentos de construção de cada eixo que tiveram como base aqueles elaborados por Morelatti (2001):

aprenda eixobarra :amplitude :amplitudepassos :escala :escalapassos mudefontejanelagráfica [[arial] 15000000$]$

at ul pf 500 pt 500 pd 90

repita (:amplitudepassos / :escalapassos) [pf:escalapassos marque] pf (:amplitudepassos / :escalapassos)

pt ( : amplitudepassos / :escalapassos +8 )

ul rotule :amplitude;

coloque :amplitude "y

enquanto [:y>0] [un pt :escalapassos coloque :y - :escala "x rotule :x coloque : $x$ " $y$ ]

pcul

fim

aprenda eixocoluna :amplitude :amplitudepassos :escala :escalapassos

mudefontejanelagráfica [[arial] 1500000$]$

at ul pd 90

pf 500 pt 500 pe 90

repita (:amplitudepassos / :escalapassos) [pf :escalapassos marque] pf ( :amplitudepassos / :escalapassos)

pf:escalapassos $/ 5$ pd 180 pf:escalapassos $/ 5$

pe 90 un pt 25 ul rotule :amplitude un pf 25 pd 90

coloque :amplitude "y

enquanto [:y>0] [pf:escalapassos coloque :y - escala "x pe 90 un pt 25 ul rotule :x coloque : $x$ "y un pf 25 pd 90]

pcul

fim

aprenda eixohistograma :amplitude :amplitudepassos :escala :escalapassos mudefontejanelagráfica [[arial] 1500000$]$

at ul pf (:amplitudepassos/:escalapassos * (:escalapassos)) pt (:amplitudepassos/

:escalapassos * :escalapassos)

repita (:amplitudepassos / :escalapassos) [pf :escalapassos marque] pf (:amplitudepassos / :escalapassos)

pf :escalapassos $/ 5$ pd 180 pf:escalapassos $/ 5$

pe 90 un pt 25 ul rotule :amplitude un pf 25 pd 90

coloque :amplitude " $y$

enquanto [:y>0] [pf :escalapassos coloque :y - escala "x pe 90 un pt 25 ul rotule :x un pf 25

pd 90 coloque : $x " y]$

pc pd $90 \mathrm{ul}$

pf 30 marque pt 8 rotule [1/2] pf 8

pf 30 marque pt 3 rotule [1] pf 3

pf 60 marque pt 3 rotule [2] pf 3 
pf 60 marque pt 3 rotule [3] pf 3

pf 60 marque pt 3 rotule [4] pf 3

pf 60 marque

un pf 15 ul rotule [HORAS]

un $p c u l$

fim

Os procedimentos acima utilizam o seguinte subprocedimento:

aprenda marque

pe 90 pf 2 pt 4 pf 2 pd 90

fim

\subsubsection{Análise e Interpretação das informações}

De posse dos gráficos e tabelas elaborados, foi possível realizar as análises e interpretações dos dados, visando a conclusões que possibilitassem responder à(s) questão(ões) inicial(is).

Trata-se da constatação sobre as contribuições da realização das atividades anteriores para a atribuição de significados às informações apresentadas nos gráficos, estimulando uma leitura global e correta dos dados, bem como a formalização da compreensão da variabilidade.

Para tanto, o aluno necessitou retomar todas as atividades desenvolvidas e os milieux, isto é, o material onde o problema lhe foi proposto, passando pelo milieu de referência onde ele retomou conceitos e experiências anteriores e chegando ao milieu de aprendizagem, onde por meio de retroações e intervenções do professor, ele se apropriou dos novos conhecimentos, o que possibilitou o desenvolvimento do trabalho de organização e apresentação dos dados. Trata-se da quarta, e fundamental, função que as representações preenchem, a identificação (DUVAL, 1999 apud FLORES; MORETTI, 2005).

Para tanto, as análises foram realizadas em três níveis: 


\subsubsection{Análise dos Dados no Nível A}

No nível A, objetivamos o início da conscientização quanto à distinção de questões estatísticas de determinísticas. Dessa forma, trabalhamos apenas com os dados da sala de aula. Portanto, as análises focalizaram exemplos específicos que visaram à percepção da variabilidade existente entre os indivíduos do grupo, por meio da comparação indivíduo com indivíduo, induzindo ao início da percepção da variabilidade entre grupos (ASA, 2005). Além disso, trabalhamos com a leitura dos dados apresentados. Os alunos utilizaram os gráficos e tabelas com os dados coletados na própria sala para fundamentar suas análises.

\subsubsection{Análise dos Dados no Nível B}

O nível $\mathrm{B}$ vislumbra mais específica sensibilização da distinção de questões estatísticas. Para tanto, os alunos trabalharam com os gráficos da sala, comparando-os com as demais oitavas séries da escola, visando a estabelecer relações e constatar divergências entre os diferentes grupos/salas. Além disso, trabalharam com amostragem sem a necessidade de uma atribuição aleatória com o intuito de comparar os dados da amostra com os dados do grupo, de modo a reconhecer um possível erro amostral. Assim, acreditamos que os alunos reconheceram que uma amostra pode ou não ser representativa de uma população maior.

\subsubsection{Análise dos Dados no Nivel C}

O nível C pressupõe que os alunos se tornem capazes de fazer distinção entre questões estatísticas e determinísticas, de forma autônoma e procurando generalizações. Além disso, devem compreender a necessidade da seleção aleatória para amostragem. Nesse nível, pretende-se que os alunos sejam capazes de medir a variabilidade, quantificar e descrever o erro amostral. Além disso, prevê que os estudantes possam aplicar e analisar modelos de associação (ASA, 2005). Neste contexto, e, de acordo com os PCN para o Ensino Fundamental, acreditamos que essa habilidade vai além das orientações, devendo ser tratada mais adequadamente no Ensino Médio. Nosso trabalho se limitou à percepção da necessidade da amostragem aleatória de forma a reduzir o erro amostral. Para tanto, discutimos com os alunos um modelo de seleção aleatória dentre os questionários colhidos, representativo da população, que considerasse as variabilidades entre indivíduos e entre grupos, discutidas nos níveis anteriores. 


\subsection{Discussão da sequência didática na perspectiva de Zabala (1998)}

Ao definirmos o que entendemos por sequência didática, fundamentamo-nos nos pressupostos de Zabala (1998), apresentados no item 2.3.2. Neste contexto, utilizamos as perguntas desse autor quanto às atividades que compõem uma sequência, estabelecendo as considerações em cada item no contexto da situação pretendida.

a) Conhecimentos prévios: a análise realizada a priori evidenciou sobremaneira as dificuldades e os conhecimentos prévios dos alunos. Contudo, as atividades desenvolvidas no SuperLogo 3.0 também as explicitaram, na medida em que foi necessário ensinar a tartaruga e para tanto, utilizar conceitos matemáticos e estatísticos decorrentes de aprendizagens anteriores.

b) Significância e funcionalidade dos novos conteúdos: por se tratar de uma investigação, cujo tema decorreu do interesse dos alunos, os conteúdos tratados tiveram significado dentro do contexto em questão, princípio fundamental da Educação Estatística.

c) Nível de desenvolvimento: o trabalho colaborativo nos grupos, bem como a autonomia e as retroações proporcionadas pelo uso do computador, facilitaram o desenvolvimento do milieu cognitivo potencial, possibilitando a aprendizagem por adaptação, já que cada atividade retomou conceitos antigos e gerou novas necessidades.

d) Conflito cognitivo e atividade mental: quando as provocações foram feitas pelo professor, situações "inesperadas" se originaram trazendo o desequilíbrio à estrutura cognitiva do indivíduo. Por exemplo, ao organizar uma tabela de dupla entrada, uma questão pode indicar erros na organização dos dados, porque a tabela pode não respondê-la. Além disso, com o trabalho de construção dos gráficos no SuperLogo 3.0, ao obter um resultado não correspondente ao esperado, o aluno também se deparou com a necessidade de refletir a respeito do erro, visando a depurá-lo (VALENTE, 2002).

e) Atitude favorável: novamente o fato de se tratar de uma investigação exploratória de dados, cujo tema decorreu do interesse e do contexto dos alunos, essa prédisposição certamente ocorreu naturalmente. 
f) Autoestima e autoconceito: a valorização das contribuições e conhecimento dos alunos por meio das discussões e participação efetiva deles desde a elaboração da questão e do instrumento de coleta de dados até a organização e interpretação de dados permitiu criar sensações positivas de autoestima e autoconceito.

g) Aprender a aprender: por envolver diferentes instrumentos desde a coleta até a análise dos dados, acreditamos que os alunos aprenderam a aprender por meio das retroações e reflexões necessárias no decorrer da sequência, a partir dos milieux antagônicos criados nas atividades.

\subsection{Considerações sobre a concepção da sequência didática}

Trata-se de uma sequência de atividades didáticas e adidáticas que tem por objetivo a devolutiva de uma situação-problema aos alunos, aspirando à percepção da necessidade e pertinência de uma investigação exploratória de dados e a vivência de todas as etapas que envolvem a resolução de um problema estatístico.

Neste contexto, a estrutura do milieu é fundamental, já que a existência de dificuldades, contradições e desequilíbrios facilita as retroações congnitivas sobre os conceitos e habilidades em jogo, com o objetivo de possibilitar a tomada de consciência e atribuição de significado ao conhecimento estatístico. Para tanto, o papel de mediador/interventor do professor é fundamental para a criação e a manutenção do milieu antagônico, na intenção de prezar pelas intenções didáticas das atividades (mesmo que essas estejam implícitas nas situações adidáticas) e aprofundar os conceitos matemáticos e estatísticos envolvidos no processo.

O GAISE, como fundamento para o desenvolvimento da literacia estatística, trouxe orientações substanciais para o desenvolvimento da sequência de atividades, tendo em vista que sua estrutura, pautada no processo de resolução de problemas e na variabilidade, reforça a Teoria das Situações Didáticas, permitindo o trabalho com os diversos milieux, bem como admitindo o rompimento com o caráter determinístico presente nas diversas atividades que envolvem conceitos e habilidades estatísticas, presentes em livros didáticos e outras orientações (conforme evidenciados nas análises preliminares). 


\section{EXPERIMENTAÇÃO: Vivenciando uma Investigação Exploratória de Dados}

Realizadas as análises preliminares, estabelecidas as etapas da sequência didática e os princípios teóricos e metodológicos que fundamentaram sua concepção e nortearam as ações no desenvolvimento das atividades, partimos para a implementação da sequência no contexto de sala de aula.

Segundo a Engenharia Didática, a experimentação caracteriza a fase da realização das atividades com os alunos, que acontece no momento em que se dá o contato professor/pesquisador com os sujeitos da investigação. Supõe a explicitação dos objetivos e condições de realização da pesquisa aos alunos, que participarão da experimentação, o contrato didático, a aplicação dos instrumentos de pesquisa e o registro das observações feitas durante a experimentação.

Apresentamos a seguir, na íntegra, as atividades que foram desenvolvidas, utilizando como referência as anotações do diário de bordo, transcritas após a realização de cada um dos 16 encontros que totalizaram 27 horas-aula. As atividades foram acompanhadas pelas professoras das Oficinas de Experiências Matemáticas (Professora D), quando realizadas nesse espaço e pela profissional de Informática Educacional (Professora N), quando envolviam o uso do computador e da SAI.

A oitava série do Ensino Fundamental (EF) foi escolhida por ser um fechamento de ciclo, o que nos permitiu avaliar amplamente a situação atual da Educação Estatística neste nível de ensino, bem como realizar a sequência didática contemplando muitas idéias e conceitos estatísticos, com o objetivo de possibilitar um trabalho mais efetivo no Ensino Médio (EM), a fim de quantificar a variabilidade e os níveis de significância para as análises realizadas no EF, conforme a orientações do Nível C do GAISE.

Para preservar a identidade da escola e dos 27 sujeitos da pesquisa, os alunos foram identificados por meio de um código $a_{i j}$, em que $i$ indica o grupo ao qual o aluno pertence (de acordo com a divisão realizada pelos próprios alunos) e $j$ é o número atribuído ao aluno dentro de seu grupo. Contamos com 07 grupos e cada um ficou responsável pelos dados das diferentes séries da escola (da $5^{\mathrm{a}}$ série do EF ao $3^{\mathrm{o}}$ ano do EM). Em se tratando de uma $8^{\mathrm{a}}$ série, escolhida de forma aleatória, essa foi denominada $8^{\mathrm{a}}$ série X. Uma síntese da forma de identificação é apresentada a seguir: 
Quadro 5: Identificação dos alunos da $8^{\mathrm{a}}$ série da $\mathrm{X}$ da Escola A, envolvidos na pesquisa

\begin{tabular}{|c|c|c|}
\hline Grupo & Integrantes & Série responsável \\
\hline G. 1 & $a_{11}, a_{12}, a_{13}$ & $5^{\text {a }}$ série do EF \\
\hline G. 2 & $a_{21}, a_{22}, a_{23}$ & $6^{\text {a }}$ série do EF \\
\hline G. 3 & $a_{31}, a_{32}, a_{33}, a_{34}, a_{35}, a_{36}$ & $7^{\text {a }}$ série do EF \\
\hline G. 4 & $a_{41}, a_{42}, a_{43}, a_{44}$ & $8^{\mathrm{a}}$ série do EF \\
\hline G. 5 & $a_{51}, a_{52}, a_{53}, a_{54}$ & $1^{\circ}$ ano do EM \\
\hline G. 6 & $a_{61}, a_{62}, a_{63}$ & $2^{\circ}$ ano do EM \\
\hline G. 7 & $a_{71}, a_{72}, a_{73}, a_{74}$ & $3^{\circ}$ ano do EM \\
\hline
\end{tabular}

\subsection{Delineamento da questão de investigação}

Para definição de um tema de interesse que fizesse parte do cotidiano dos alunos iniciamos uma discussão sobre as atividades por eles realizadas nos momentos em que não estão na escola, durante a semana e aos finais de semana. Essa estratégia se baseou na afirmação de Lopes e Carvalho que, a partir de Gal e Garfield (1999), destacam

a importância de fornecer aos estudantes oportunidade de trabalhar com dados reais, quer resolvendo problemas interessantes, quer propondo problemas deles próprios, que os levem a seguir os passos da investigação estatística (LOPES; CARVALHO, 2009, p. 89).

Acreditávamos que, ao trabalhar com um tema do contexto deles, poderíamos proporcionar o trabalho com dados reais e significativos, bem como atribuir sentido às etapas da investigação estatística, quais sejam, coleta, organização, apresentação, análise e interpretação dos dados.

O discurso dos alunos verbalizou que, em síntese, quando não estão na escola, utilizam computador para navegar na Internet, bater papo em sites de relacionamento, fazer pequenas pesquisas, baixar e ouvir músicas, baixar e assistir vídeos, baixar jogos e jogar e, finalmente, utilizar alguns aplicativos como o Paint, Photoshop, Word e Excel. Além disso, os alunos assistem à TV, ouvem música (em muitos casos, também utilizando o computador) e comunicam-se com os amigos por meio da Internet e do telefone (em alguns casos, utilizando o celular). Cabe destacar que quase a totalidade da sala (88\%) possui aparelho celular. No entanto, quando questionados acerca da forma de utilização desta tecnologia, os alunos afirmaram que "o que menos fazem é ligar e/ou receber ligação": na verdade eles utilizam o celular para enviar torpedos Short Message Service (SMS), tirar fotos, filmar, gravar sons, assistir vídeos e programas de TV e acessar a Internet. 
Diante dessas afirmações, fizemos algumas provocações no sentido de levá-los a refletir a respeito das informações ali apresentadas. Elas seriam iguais, se tomássemos uma outra sala, ou se ainda pensássemos, numa visão mais ampla, em todos os alunos da escola?

A partir desse questionamento, os alunos passaram a explicitar argumentos para justificar a sua opção, fosse ela afirmativa ou negativa. Após algumas discussões, levantamos a questão seguinte. Diante das divergências apresentadas e dos argumentos utilizados nas justificativas, seria interessante realizar uma investigação comparativa entre os alunos da sala e os demais alunos da Escola A?

A resposta foi positiva e concluímos, portanto, que encontramos um tema relevante e de interesse dos alunos para fundamentar nossa investigação exploratória: “A relação estabelecida entre os alunos da Escola A e as mídias ${ }^{26 "}$. Para tanto, partimos do princípio de discutirmos o que dizem os alunos sobre "mídia".

Perguntamos o entendiam por mídia. As respostas sempre se relacionavam com meios de comunicação.

É algo que me passa alguma coisa, um tipo de informação talvez $\left(a_{35}\right)$.

Ah, professor. Tipo TV, computador, rádio, celular... $\left(a_{43}\right)$.

Os estudantes recorreram a múltiplos exemplos para explicitar sua compreensão quanto ao conceito em questão. Na verdade, o entendimento deles não estava errado. Assim, formalizamos o conceito de mídia explicando que se trata de todo suporte de difusão da informação que constitui um meio intermediário de expressão capaz de transmitir mensagens, podendo ser consideradas como meios de comunicação social de massas não diretamente interpessoais. Assim, abrange o rádio, o cinema, a televisão, a escrita impressa (ou manuscrita, no passado) em livros, revistas, boletins, jornais, o computador, o videocassete, os satélites de comunicações e, de um modo geral, os meios eletrônicos e telemáticos de comunicação em que se incluem também as diversas telefonias (BELLONI, 2001).

\footnotetext{
${ }^{26}$ Conforme descreveremos no item de estruturação do questionário de coleta de dados, diante da constatação que a questão de investigação se tornaria muito ampla e complexa, em comum acordo com os alunos, reduzimos sua forma para atingir apenas as mídias digitais (computador e celular), na seguinte conformidade: "A relação estabelecida entre os alunos da Escola A e as mídias digitais - computador e celular".
} 


\subsection{Estruturando a Instrumento de Coleta de Dados}

Definido o tema de investigação, partimos então para a elaboração do instrumento de coleta de dados. Perguntamos aos alunos qual seria a forma mais fácil para a coleta desses dados, obtendo como resposta o questionário. Partimos para sua elaboração, considerando as discussões em sala de aula e estruturando as questões na lousa. Posteriormente, fomos à SAI da escola para transcrevê-lo para sua forma final (APÊNDICE C).

A questão que iniciou a discussão foi a seguinte: Quais características dos alunos podem influenciar suas opiniões? Essa questão objetivou fazer com que os alunos iniciassem o processo de percepção do aspecto de variabilidade, na medida em que as características dos alunos podem variar entre os sexos e entre as séries/idades, por exemplo. Como resposta, obtivemos: série, sexo, nome e endereço. Decidimos discutir cada um dos itens separadamente.

Quanto ao componente série, os alunos esclareceram que adolescentes de séries diferentes podem ter opiniões diferentes e que, portanto, esse deveria ser um item considerado. Diante disso, questionamos se os alunos de uma mesma série tinham a mesma idade ou existia alguma variação. Eles disseram que existia variação, pois, por exemplo, na sala em que estávamos havia alunos de 14 e 15 anos. Então questionamos se, com o mesmo argumento da série, a idade poderia ser outro fator a ser considerado. Os alunos concordaram e decidimos contemplar idade e série no questionário.

Quanto ao sexo, os alunos afirmaram que as meninas, por exemplo, utilizam o computador com finalidades diferentes dos meninos. Portanto, seria interessante fazer essa comparação.

Questionamos o porquê de se considerar o nome e o endereço e alguns alunos disseram que todo investigador que passa em suas casas ou os abordam nas ruas, sempre pergunta o nome e o endereço (e em alguns casos o telefone) e que, portanto, eles achavam que deveriam ser considerados esses dois aspectos. Diante do argumento, fizemos a seguinte provocação: será que existe algum motivo para esses pesquisadores solicitarem o nome e o endereço? Após algumas considerações um dos alunos disse que recebia muitos telefonemas em sua casa oferecendo produtos e serviços. Perguntamos-lhes se isso teria alguma relação com o que estávamos discutindo, visando a concluir que as informações solicitadas serviam para que as empresas/instituições pudessem contatar as pessoas e/ou enviar-lhes materiais promocionais posteriormente. Diante dessa constatação, voltamos à questão inicial: O nome e 
o endereço são relevantes para nosso objetivo? Depois de toda a discussão os alunos já haviam percebido que, para nós, esses dois fatores poderiam ser desconsiderados, salvo no caso de se ponderar o bairro de origem dos alunos como uma das variáveis que poderiam influenciar nossos resultados. No entanto, optaram por não abordar semelhante característica, em razão da possibilidade de o trabalho se tornar muito amplo e complexo.

Não havendo mais fatores para discussão passamos à elaboração das questões.

Iniciamos pelo computador. Os alunos acharam que era necessário saber se os adolescentes tinham computador em casa. Assim, elaboramos a questão: Você tem computador na sua casa?

Em seguida, os estudantes optaram pelos locais em que os alunos fazem uso do computador e elaboraram a segunda questão: Onde você usa o computador? Como alternativas indicaram: em casa, na escola, em lan house e cybers, na casa de amigos, conhecidos e/ou familiares. Consideraram uma alternativa para aqueles que não fazem uso do computador.

A terceira questão abordou o tipo de uso do computador. Decidiram elaborar a seguinte questão: O que você faz no computador? Como alternativas, indicaram: relacionamento (MSN e Orkut), jogos; música (baixar/ouvir), vídeos (baixar/assistir), pesquisas, aplicativos (Word, Excel, Powerpoint, Paint, Photoshop) e, novamente, a alternativa para quem não faz uso do computador. Percebendo que poderíamos ter problemas com a questão na forma como foi estruturada, solicitamos para que um aluno a respondesse. Conforme o esperado, o aluno indicou todas as alternativas, justificando que tudo o que estava posto, de alguma forma, ele realizava no computador. Assim, questionamos aos alunos se poderíamos melhorar a questão, de forma a torná-la mais relevante para nossos objetivos, tendo em vista o fato de que, caso eles assinalassem todas as alternativas, poderia não trazer informação alguma que possibilitasse qualquer inferência ou conclusão.

Professor, e se a gente pensar no maior uso do computador, tipo as coisas que ele faz numa ordem? $\left(a_{52}\right)$.

Perguntamos se a aluna se referia a uma ordem de precedência. Ela disse que sim, pois isso originaria informações interessantes e impediria que os alunos indicassem mais de uma alternativa. Os demais concordaram, embora identificassem que a questão ficaria complicada.

Mas professor, não vai ficar complicado pra entender o que a gente quer? $\left(a_{41}\right)$

Não pode colocar um exemplo de como fazer? Tipo, um o que você mais faz, dois a segunda coisa, três a terceira... $\left(a_{52}\right)$. 
A questão foi alterada para: Enumere apenas os itens que você utiliza no computador, em ordem decrescente (exemplo: 1 - o que você mais faz; 2 - a $2^{\mathrm{a}}$ coisa que mais faz; e assim por diante).

Além disso, definimos em conjunto que seria interessante analisarmos o tempo médio diário que os adolescentes ficam no computador. Em decorrência, criamos uma questão tratando da variável numérica contínua: tempo de uso do computador: Quanto tempo você costuma ficar no computador por dia? Como resposta, os alunos sugeriram a não utilização, até meia hora, de meia até uma hora, entre uma e duas horas, entre duas e três horas, entre três e quatro horas e mais que quatro horas. Diante disso fizemos um questionamento: uma pessoa que fica duas horas por dia no computador deve assinalar a quarta ou a quinta alternativa? Trata-se de alternativas que se sobrepõem e, de acordo com o GAISE (ASA, 2005), as respostas não devem se sobrepor . Dessa forma, fizemos adaptações nas alternativas evitando qualquer dúvida, criando as seguintes alternativas: não uso o computador; menos de meia hora; de meia hora a menos de 1 hora; de 1 hora a menos de 2 horas; de 2 horas a menos de 3 horas; de 3 horas a menos de 4 horas; mais de 4 horas.

Nada mais havendo de interesse dos alunos no que se refere ao computador, partimos para o celular, a fim de identificar o tipo de uso dessa tecnologia, enquanto mídia. Novamente caímos na questão do indivíduo ter ou não celular - nos moldes da questão que envolvia o computador. Sugerimos que repensássemos a questão inicial, para torná-la mais ampla, contemplando todos os aparelhos que estamos tratando. A questão assumiu a seguinte forma: Indique, dentre os itens abaixo, o que você tem na sua casa. Como alternativas: computador, celular, TV, rádio e videogame.

A elaboração da questão envolvendo a forma de uso do celular foi iniciada. Neste momento, os alunos perceberam, assim como na questão que envolvia o uso do computador, a necessidade de estruturá-la para proporcionar respostas relevantes ao que se pretendia. Para fazê-lo, experimentaram raciocínio análogo ao da questão que envolvia o uso do computador. Como resultado, a questão foi elaborada no mesmo modelo: Enumere apenas os itens que você utiliza no celular, em ordem decrescente (exemplo: 1 - o que você mais faz; 2 - a $2^{\mathrm{a}}$ coisa que mais faz; e assim por diante). Como alternativas de respostas, sugeriram as seguintes: não uso celular, ligar e receber chamadas, tirar e ver fotos, ouvir música, fazer e assistir a vídeos, enviar e receber torpedos SMS, acessar a internet, assistir à TV e jogar.

Ao discutir as outras mídias, os alunos constataram que o questionário se tornaria muito longo. Assim, em comum acordo, resolvemos tratar apenas do computador e 
do celular, delimitando o tema da investigação à relação dos alunos com as chamadas mídias digitais. Dessa forma, foi revista a questão que envolvia as mídias que os alunos possuíam. A questão do uso ficou da seguinte maneira: Indique, dentre os itens abaixo, o(s) que você usa. Como alternativas, apenas o computador e o celular. Assim, fechamos o questionário de coleta de dados dos alunos.

A atividade possibilitou-lhes experienciar a elaboração de questões que ratificassem os objetivos estabelecidos inicialmente. $\mathrm{O}$ envolvimento foi perceptível, em consequência da necessidade de refletir quanto à maneira mais adequada para elaboração da questão. Percebemos que o papel do professor na estruturação de um milieu antagônico facilita/propicia a participação e o envolvimento dos alunos nas atividades, mesmo que se trate de uma situação adidática como esta.

Além disso, a conversão da expressão oral em escrita já evidenciou algumas dificuldades, de acordo com a Teoria de Registros de Representação Semiótica. Um exemplo foi a organização das questões que envolviam os tipos de uso para o computador e para o celular, porque os alunos sabiam dizer o que queriam, mas levaram um tempo razoável para conseguir transcrevê-lo no registro adequado.

\subsection{Coleta dos Dados}

Elaborado o questionário, discutimos a melhor estratégia para a coleta dos dados, tendo em vista que num levantamento a priori concluímos que teríamos aproximadamente 700 sujeitos envolvidos na pesquisa. Na verdade, foram aplicados 524 questionários, conforme apresentado no resumo do APÊNDICE D. Os alunos sugeriram que a sala fosse dividida em grupos e que cada grupo se responsabilizasse pela coleta, organização e apresentação dos dados de determinada série, visto que a escola atende alunos da $5^{\mathrm{a}}$ série $^{27}$ do Ensino Fundamental ( $6^{\circ}$ ano) ao $3^{\circ}$ ano do Ensino Médio. Achamos a ideia interessante, na medida em que todos teriam de se empenhar efetivamente na realização do trabalho, haja vista o grande número de dados a serem coletados e analisados e a comparação entre os registros dos diferentes grupos proporcionaria discussões ricas quanto à variabilidade entre indivíduos e entre grupos.

\footnotetext{
${ }^{27}$ Apesar de estar implementado o Ensino Fundamental (EF) de 9 anos, alterando, portanto, a denominação das séries, neste trabalho, pela própria natureza de envolver os alunos que não estão habituados com a nova terminologia, optamos por manter as denominações de $5^{\mathrm{a}}, 6^{\mathrm{a}}, 7^{\mathrm{a}}$ e $8^{\mathrm{a}}$ séries do EF, em referência aos $6^{\circ}, 7^{\mathrm{o}}, 8^{\mathrm{o}}$ e $9^{\mathrm{o}}$ anos da nova estrutura do EF.
} 
Os questionários foram aplicados inicialmente na sala de aula, a qual desempenhou o papel de piloto para identificação de possíveis problemas na estruturação das questões. Os alunos identificaram dois erros de digitação que foram corrigidos. Decidimos também padronizar a apresentação da proposta com um pequeno texto, disposto da seguinte forma: "Prezado Colega, este questionário faz parte de uma pesquisa da $8^{\mathrm{a}}$ série $\mathrm{X}$ sobre as relações que os alunos da Escola A têm com as diversas mídias. A sua participação é muito importante. Contamos com a sua colaboração! Muito obrigado!"

Finalizado e estruturado o questionário, os alunos se dividiram em grupos, na média de 3 a 4 pessoas (de acordo com o Quadro 5) e passaram a coletar os dados nas salas de aula.

Não pudemos acompanhar a aplicação de todos os questionários, em consequência de horários bastante variados. Acompanhamos alguns grupos, para avaliar o transcurso da atividade, o que se revelou deveras interessante. Os alunos atuaram como pesquisadores, de fato, no sentido de transmitir as devidas orientações sobre o preenchimento do questionário, esclarecer dúvidas e realizar conferências no momento de recolhimento visando a minimizar os erros de preenchimento - muitos dos quais relativos às questões que tratavam da indicação dos itens de uso de forma ordenada (questões 05 e 07$)^{28}$.

Os alunos não lêem o que está pedindo. Estava escrito que era pra numerar o que usava e o 'cara' ia lá e marcava um $x\left(a_{11}\right)$.

Novamente, releva-se a experiência de investigação a partir da ação dos alunos porque, no momento da coleta dos dados, eles puderam perceber que as questões elaboradas poderiam ser melhores, de modo a facilitar e clarear o preenchimento do questionário, tendo em vista que a qualidade dos dados obtidos depende substancialmente da qualidade do instrumento utilizado (ASA, 2005).

\footnotetext{
${ }^{28}$ Outros equívocos no preenchimento dos questionários serão apresentados e discutidos no item de organização dos dados.
} 


\subsection{Organização dos Dados}

Com os dados em mãos, auxiliamos os alunos na sua tabulação, recorrendo a anotações na lousa da sala de aula e ao software Excel, em virtude de não podermos utilizar a SAI nas aulas de Experiências Matemáticas, porque a escola só autoriza este uso nas aulas de Informática Educacional. O trabalho revelou-se motivador, em razão de seus desdobramentos, como, comparação de atitudes, possibilidades e limitações dos alunos quando organizam dados no papel e quando isso ocorre com a utilização de um software, no nosso caso, o Excel.

Tratamos, inicialmente, os dados referentes à $8^{\mathrm{a}}$ série $\mathrm{X}$ e depois os das demais salas. Para organizá-los, cada um dos sete grupos ficou com alguns questionários (de 3 a 4 ) para podermos realizar a análise, visando ao início da percepção da variabilidade dentro do grupo e entre os subgrupos criados. Iniciamos a organização dos dados apenas distribuindo o número de alunos que responderam ao questionário entre meninos e meninas, bem como suas idades. Para tanto, questionamos a respeito de uma maneira de fazer isso. Eles sugeriram a organização de duas tabelas simples, uma com a distribuição de frequência de gênero e outra com a distribuição de frequência das idades.

Organizadas tabelas de frequência, questionamos os alunos quanto aos percentuais que cada um dos números dispostos na tabela representava do total de alunos da sala que responderam ao questionário (26 alunos). Um das alunas disse que bastava dividir os números por 100. Fizemos então as divisões para a tabela de distribuição entre meninos (11 alunos) e meninas (15 alunas), concluindo que tínhamos 11\% de meninos e 15\% de meninas. Mas, qual deveria ser o total (em termos percentuais) da sala? Os alunos responderam que deveríamos ter $100 \%$. Então perguntamos onde estava os outros $74 \%$ que faltava.

$$
\text { Professor... Não é o 100? Ah! Não sei }\left(a_{41}\right) \text {. }
$$

Os alunos afirmaram que os cálculos estavam errados. No entanto, quando questionados acerca do porquê do erro, não souberam responder. Passamos, então, a uma discussão sobre o que é porcentagem.

Iniciamos as discussões a partir das três formas de representação de porcentagens com idêntica significação, apenas com notações diferentes, remetendo-nos ao princípio de tratamento de Duval (2003) - fracionária (por exemplo, 5/100), decimal (por exemplo, 0,05) e com o sinal de porcentagem (por exemplo, 5\%). Apesar de se tratar de uma transformação interna, como ela ocorria no mesmo tipo de registro em todos os casos, o algébrico, foi possível perceber a dificuldade dos alunos em estabelecer as relações existentes 
entre eles, isto é, transpor os aspectos de registros diferenciados e se ater ao seu caráter semântico.

Assim, iniciamos pela representação fracionária, passando pelo processo de resolução da fração, chegando a sua representação decimal. Posteriormente, partindo do princípio de que a porcentagem é uma fração (razão) cujo consequente é 100, explicamos que para se obter a forma em percentual basta multiplicarmos a representação decimal por 100, haja vista que ela nada mais representa que o percentual dividido por 100 .

Lopes e Moran (1999), analisando alguns livros didáticos do Ensino Fundamental, destacam quão substancial é o conceito de porcentagem para o raciocínio estatístico e probabilístico, porque possibilita o rompimento com o caráter determinístico na Educação Estatística - presente na maioria das atividades que tomam a Estatística como ferramenta para simples cálculos matemáticos - e possibilita o desenvolvimento da compreensão do caráter variável dos dados.

Trabalhar esse conceito [porcentagem] com os estudantes não seria uma tarefa tão difícil se deixarmos que os alunos experimentem e convivam com a variabilidade. Consideremos que se tivermos em 100 bolas, 50 pretas e 50 brancas, e perguntarmos ao aluno em uma amostra de 10 bolas quantas se teria de cada cor, muito provavelmente, no contexto de aprendizagem de porcentagem, ele responderá que em 10 bolas amostradas ocorreriam 5 de cada cor. Esse é um conceito que urge ser trabalhado, para que seja aplicado, corretamente, na resolução de problemas estatísticos (LOPES; MORAN, 1999, p. 172).

Neste contexto, trabalhamos num sentido inverso ao exemplificado pelas pesquisadoras, mas com o mesmo objetivo. Utilizamos os dados empíricos dos alunos da sala - distribuição entre meninos e meninas e idades - para que os alunos pudessem retirar amostras e descobrir os percentuais - assim poderiam inferir os percentuais para toda a sala. Por se tratar de um grupo pequeno de alunos, a atividade poderia ficar comprometida. No entanto, como existia um número muito grande de alunos com 14 anos de idade (92\%) e a distribuição entre meninos e meninas era equilibrada, retirando amostras aleatórias, por meio do sorteio pelos números dos alunos, eles compreenderam que, em sua maioria, tínhamos metade meninos e metade meninas, e que a idade predominante era 14 anos. Dessa forma, reconheceram que as porcentagens deveriam girar em torno de $50 \%$ para cada um dos sexos e se aproximar de $100 \%$ para a idade de 14 anos. Raciocinando sobre os dados das tabelas e analisando as porcentagens constatadas nas amostras, os alunos puderam apontar que o erro estava no razão de representação da porcentagem. $O$ antecedente estava correto, mas o consequente - considerado como 100 - estava errado, em razão de o 100 se referir à totalidade de alunos, que, no caso, era 26 e não 100. Assim, numa linguagem mais próxima de sua realidade uma das alunas perguntou: 
Professor, então podemos considerar que a porcentagem é uma parte, um grupo, sobre todo mundo da sala? $\left(a_{52}\right)$

Fizemos uma discussão com os alunos a respeito do raciocínio da colega, questionando sobre o que eles achavam. Concluímos que o raciocínio estava correto, e então foram realizados os cálculos das frequências relativas para cada uma das tabelas.

Ficou evidente o reflexo nos alunos objeto da investigação da constatação de Lopes e Moran (1999) de que os livros didáticos não associam porcentagem com investigação estatística. Ainda que o conceito de porcentagem seja trabalhado desde o $2^{\circ}$ ciclo do Ensino Fundamental, aqueles que estão em fase de conclusão desse nível de ensino apresentaram dificuldades, tanto na semiósis quanto na noésis. A experimentação com dados reais mostrouse como uma alternativa viável e pertinente para atribuição de significado ao conceito de porcentagem.

Outra constatação advinda dessas atividades foi a de que todos os alunos utilizaram a calculadora para efetuar os cálculos, muitas vezes, recorrendo ao celular. Explicamos que o Excel realiza esses cálculos automaticamente, desde que seja indicada corretamente a função que se deseja. Assim, foi sugerido que testassem essas funções na próxima aula.

$\mathrm{Na}$ aula seguinte levamos os alunos para a SAI a fim de reproduzirmos as tabelas no Excel. Apesar de todos já conhecerem o software, inclusive desenvolvendo atividades na escola, tiveram dificuldade para reproduzir a estrutura construída no caderno. Solicitamos que a linha totalizadora e as frequências relativas fossem calculadas por meio das funções do Excel, o que gerou bastante dificuldade na estruturação da função para o cálculo da porcentagem. Além disso, depois de calculadas as porcentagens, ocorreram problemas, porque alguns alunos obtiveram como resultado $100 \%$, outros 1 , e outros ainda 1,003. Passamos às discussões sobre esses resultados, de forma que eles os associassem à primeira discussão, referente às conversões de registro da tabela. Eles retomaram as discussões realizadas na aula anterior, percebendo que se tratava dos diferentes tipos de registro discutidos. Explicamos como poderiam alterar a formatação da célula, visando a apresentar seus resultados na forma de percentual.

A atividade possibilitou a percepção de que o Excel funcionou como uma ferramenta facilitadora no processo de construção das tabelas, até mesmo em virtude de sua estrutura, na medida em que automatiza os cálculos que, apesar de serem importantes para a atividade estatística, não devem ser priorizados. No entanto, o que nos preocupa é o fato de que, apesar de todos os alunos afirmarem ter desenvolvido atividades escolares no Excel, 
nenhum manifestou familiaridade com a estruturação de funções e cálculos em suas planilhas. Fica a questão: o que tem sido trabalhado nas aulas envolvendo essa planilha eletrônica, já que não se aborda seu principal potencial que são as funções e cálculos automatizados?

Organizados os dados iniciais, partimos para as questões que envolviam a posse e a utilização do computador e do aparelho celular, novamente, na sala de aula. Como os alunos distribuíam os dados de forma semelhante às anteriores, utilizando duas tabelas simples, questionamos se, com os dados organizados daquela maneira, seria possível saber quantos alunos, por exemplo, não tinham computador, mas faziam uso dele em outros lugares. Constatando que não era possível chegar ao número preciso, passamos a discutir uma maneira de organizar os dados de modo que pudéssemos responder nosso questionamento de maneira fácil e rápida, ou seja, a construção de uma tabela de dupla entrada.

Como era de se esperar pelas análises realizadas anteriormente, os alunos não conseguiram encontrar uma maneira para organizar os dados com o objetivo de atender à necessidade em questão. Iniciamos a discussão, encaminhando-a em direção ao esclarecimento necessário. Um dos alunos respondeu que precisávamos relacionar o "ter computador" com o "usar computador". Nesse momento, perguntamos-lhes se poderíamos chamar essas duas "coisas" de variáveis. Os alunos concordaram e passamos a tratar a forma de articular duas variáveis, sobre os pressupostos de que a leitura e, por conseguinte, a organização da tabela de dupla entrada é muito mais complexa, envolvendo uma exploração vertical e horizontal dos dados, em ocorrência simultânea (DUVAL, 2002 apud FLORES; MORETTI, 2005).

Tentamos estabelecer uma analogia com algo que fosse de interesse e do cotidiano deles e que envolvesse uma relação horizontal x vertical. Perguntamos, então, se na sala havia alguém que jogava xadrez e três alunos se manifestaram. Solicitamos-lhes que explicassem para os demais a forma de marcação de uma jogada - referência para a localização da peça no início e ao final da jogada - num jogo oficial. Eles, então, explicaram que utilizavam os números das colunas e as letras das linhas para indicar o movimento a ser feito. Nesse momento, o professor interveio: poderíamos fazer alguma analogia da forma de marcação do jogo de xadrez com a nossa necessidade de articular duas variáveis numa única tabela? Depois de reconstruirmos a explicação completa do aluno que jogava xadrez na lousa, uma das alunas disse que poderíamos utilizar o computador como sendo as linhas e o celular como sendo as colunas. Indagamos-lhe quais seriam as variáveis existentes para o computador e para o celular e ela nos respondeu que seria o ter e o utilizar. 
Quadro 6: Esboço da proposta de organização dos dados da aluna

\begin{tabular}{|c|c||c|c|}
\hline \multicolumn{2}{|c||}{} & \multicolumn{2}{c|}{ COMPUTADOR } \\
\cline { 2 - 4 } \multicolumn{2}{|c|}{} & tem & usa \\
\hline \multirow{2}{*}{ CELULAR } & usa & & \\
\cline { 2 - 4 } & tem & & \\
\hline & & & \\
\hline
\end{tabular}

Questionamos qual seria a leitura para os alunos que estivessem na coluna "usa" e na linha "tem". Os alunos não conseguiram entender o princípio de localização, mas um deles disse:

São os alunos que têm celular e usam computador $\left(a_{41}\right)$.

Perguntamos quão relevante seria essa informação para o nosso interesse. A resposta foi de que não tínhamos interesse nenhum nessa informação. Retomamos as discussões.

Realizamos provocações junto aos alunos com o objetivo de que eles percebessem quais eram as duas variáveis que estavam em jogo.

Não é o fato de ter e usar computador, professor? $\left(a_{43}\right)$

Mas então não precisamos fazer duas tabelas? Uma pro computador e uma pro celular? $\left(a_{41}\right)$

Perguntamos como seria:

Ao invés de computador e celular na tabela, tem que ter "tem" e "usa", e dentro de cada um, sim e não $\left(a_{41}\right)$.

Dessa forma, construímos a tabela de dupla entrada para os dados referentes ao computador, contemplando os dados dos alunos que tinham e que usavam a mídia, conforme apresentado no Quadro 7.

Quadro 7: Estrutura da tabela para os dados referentes ao computador

\begin{tabular}{|c|c|c|c|}
\hline \multirow{2}{*}{\multicolumn{2}{|c|}{ COMPUTADOR }} & \multicolumn{2}{|c|}{ USA } \\
\hline & & Sim & não \\
\hline \multirow{2}{*}{ TEM } & $\operatorname{sim}$ & & \\
\hline & não & & \\
\hline
\end{tabular}

Elaboramos as duas tabelas de frequência para o computador e o celular.

$\mathrm{Na}$ aula seguinte, solicitamos que as tabelas fossem reproduzidas no Excel, tendo em vista que estávamos novamente na SAI. Questionamos-lhes, então, como 
poderíamos organizar as frequências relativas (porcentagens) de cada uma delas. Um grupo sugeriu que fizéssemos outra tabela com a mesma estrutura, só que apresentando as porcentagens. Em decorrência da sugestão, emergiu a necessidade de linhas e coluna totalizadoras que viabilizassem os cálculos das frequências relativas no Excel. Assim, foram acrescentadas linhas e colunas nas tabelas anteriores, configurando a estrutura apresentada no Quadro 8.

Quadro 8: Estrutura da tabela para os dados referentes ao computador acrescida das linhas e colunas totalizadoras

\begin{tabular}{|l|c||c|c|c|}
\hline \multirow{2}{*}{ COMPUTADOR } & \multicolumn{3}{|c|}{ USA } \\
\cline { 2 - 5 } & $\operatorname{sim}$ & Não & TOTAL \\
\hline \multirow{3}{*}{ TEM } & $\operatorname{sim}$ & & & \\
\cline { 2 - 5 } & não & & & \\
\cline { 2 - 5 } & TOTAL & & & \\
\hline
\end{tabular}

Com estrutura semelhante, organizaram as tabelas de porcentagens, dividindo cada um dos valores pelo total de alunos. Alguns deles fizeram isso operando os valores da tabela de frequências, mas dois grupos já utilizaram as referências das células para indicar as funções operatórias, recorrendo aos princípios de tabela dinâmica do Excel.

Organizadas as duas tabelas, encaminhamo-nos para os dados referentes aos locais de uso do computador. Os alunos perceberam que uma tabela simples resolveria o problema e organizaram-na. No entanto, ficaram em dúvida quanto à linha totalizadora, tendo em vista que, ao somar todas as frequências, o número obtido era muito superior ao total de alunos entrevistados. Retomamos, então, as discussões da maneira como o instrumento de coleta de dados foi construído, tendo em vista que as tabelas

[...] não são representações autônomas, como, aliás, todas as representações que privilegiam a visualização. Isto quer dizer que elas se articulam de maneira explícita, ou implícita, com representações num outro registro. Esta articulação, que diz respeito à interação entre a tabela e o enunciado verbal do problema, ou a escritura algébrica, é essencial já que será essa possibilidade que comandará a maneira de ler uma tabela. É a conversão entre os registros que possibilitará uma leitura global das representações gráficas (FLORES; MORETTI, 2005, p. 11).

Observando a estrutura da questão, os alunos puderam perceber que os respondentes poderiam indicar todos os locais nos quais utilizavam o computador isto é, mais de um. Dessa maneira, para cada um dos itens poderíamos ter um número total de respostas iguais, jamais superior, ao número de alunos respondentes. Trabalhamos com esses dados. 
Essa questão voltou a ser tratada no momento do cálculo das frequências relativas, haja vista o conceito de porcentagem.

Ainda que os alunos, de maneira geral, demonstrassem dificuldades nos cálculos de porcentagem, percebemos significativos avanços, já que por si sós conseguiam fazer conjecturas acerca desses cálculos referentes a cada uma das classes, bem como observavam que, quando o total não atingia 100\%, havia algo de errado.

O passo seguinte foi a organização dos dados referentes às formas de uso do computador. Pareceu-nos que os alunos haviam se esquecido da estrutura da questão elaborada no questionário, visto que não sabiam como organizar os dados. Argumentavam que nem a tabela simples, nem a de dupla entrada resolvia o problema, afinal não sabiam onde colocariam os números da ordem de precedência.

Retomamos as discussões no sentido de que percebessem que uma tabela de dupla entrada resolveria o problema, tendo como variáveis os tipos de uso e ordem de preferência. Após muita discussão, perceberam que indicar um número de ordem em cada coluna, resolveria o problema. Assim, organizaram a tabela de frequência para a questão 5 (Tabela 1) e, de forma semelhante, para a questão 7, que tratava dos tipos de uso do celular (Tabela 2).

Tabela 1: Organização dos dados da $8^{\mathrm{a}}$ série X para a Questão 5.

\begin{tabular}{|c|c|c|c|c|c|c|c|}
\hline \multicolumn{8}{|c|}{ Forma de Utilização do Computador } \\
\hline \multirow{2}{*}{ Tipo de Utilização } & \multicolumn{6}{|c|}{ Prioridade } & \multirow[b]{2}{*}{ Total } \\
\hline & 1 & 2 & 3 & 4 & 5 & 6 & \\
\hline MSN e Orkut & 15 & 6 & 3 & 0 & 0 & 2 & 26 \\
\hline Jogos & 8 & 2 & 6 & 5 & 3 & 1 & 25 \\
\hline Músicas & 4 & 10 & 6 & 1 & 4 & 0 & 25 \\
\hline Vídeos & 0 & 5 & 2 & 14 & 2 & 2 & 25 \\
\hline Pesquisas & 0 & 2 & 7 & 2 & 11 & 4 & 26 \\
\hline Aplicativos & 0 & 0 & 2 & 3 & 3 & 14 & 22 \\
\hline Não Usa & \multicolumn{6}{|c|}{0} & 0 \\
\hline
\end{tabular}


Tabela 2: Organização dos dados da $8^{\mathrm{a}}$ série X para a Questão 7.

\begin{tabular}{l|c|c|c|c|c|c|c|c|c}
\hline \multicolumn{7}{c}{ Forma de Utilização do Computador } \\
\hline \multirow{2}{*}{ Tipo de Utilização } & \multicolumn{7}{c}{ Prioridade } & \multicolumn{1}{c}{ Total } \\
\cline { 2 - 12 } & $\mathbf{1}$ & $\mathbf{2}$ & $\mathbf{3}$ & $\mathbf{4}$ & $\mathbf{5}$ & $\mathbf{6}$ & $\mathbf{7}$ & $\mathbf{8}$ & \multicolumn{2}{c}{ To } \\
\hline Ligações & 10 & 5 & 3 & 2 & 0 & 0 & 0 & 0 & 20 \\
\hline Fotos & 4 & 4 & 4 & 2 & 1 & 0 & 0 & 1 & 16 \\
\hline Músicas & 4 & 8 & 4 & 2 & 0 & 0 & 0 & 0 & 18 \\
\hline Vídeos & 0 & 0 & 0 & 3 & 2 & 7 & 1 & 1 & 14 \\
\hline Torpedos SMS & 2 & 2 & 5 & 3 & 3 & 1 & 1 & 1 & 18 \\
\hline Internet & 0 & 0 & 1 & 0 & 1 & 3 & 7 & 1 & 13 \\
\hline Assitir TV & 0 & 0 & 0 & 0 & 2 & 0 & 2 & 6 & 10 \\
\hline Jogar & 0 & 2 & 1 & 5 & 6 & 3 & 1 & 0 & 18 \\
\hline Não Usa & & & 6 & & & 6 \\
\hline
\end{tabular}

Finalmente, em sala de aula, chegamos à questão que tratava do número de horas de utilização do computador, por dia. Iniciamos as discussões, questionando-os se existia alguma diferença para aquela questão, se comparada com as outras. Alguns alunos disseram que precisava de uma tabela de dupla entrada, mas quando perguntados por que, disseram que estavam errados. Os alunos não conseguiram concluir por si sós que se tratava de uma variável contínua, o tempo, ao contrário das demais tratadas nas outras questões, que eram categóricas. Dessa forma, explicamos, por meio do uso de uma linha contínua na lousa que, ao contrário das outras questões, os limites das classes indicadas como possibilidades para a resposta eram tênues - quando terminada uma já tinha início a outra. Por isso, as variáveis eram chamadas de contínuas. Discutimos a tabela que deveríamos organizar.

Os alunos perceberam, com certa facilidade, que, com uma tabela simples, o problema seria resolvido. Encaminhamos a discussão sobre como representaríamos o intervalos de hora - indicados na linha contínua da lousa. Surpreendentemente, os alunos sugeriram que utilizássemos os sinais de maior $(>)$ e menor $(<)$. Antes de darmos continuidade, fizemos uma discussão acerca do entendimento deles com relação aos dois sinais. Como esperávamos, os alunos haviam aprendido os sinais de forma equivocada. Utilizavam a "regra" se corta o sinal e "vira" 4 é menor, se corta vira 7 é maior. Essa concepção se equivoca, na medida em que ambos os sinais podem ser lidos nos dois sentidos (direita para esquerda ou esquerda para a direita) e dessa maneira, de acordo com o sentido da leitura, o maior pode ser lido como menor e vice-versa. Fizemos, então, a explicação disso para os alunos.

Perguntamos-lhes sobre a maneira como iríamos representar cada um dos intervalos utilizando os símbolos que eles sugeriram, na medida em que de acordo com Duval (2003) temos uma conversão de um Registro de Representação Discursiva Multifuncional 
(por exemplo, de meia hora a menos de uma hora) para um Registro de Representação NãoDiscursiva Monofuncional (por exemplo, $\frac{1}{2} \leq t<1$ ). Pelo que pudemos perceber, parece que, por se tratar de uma situação significativa para eles, os alunos não tiveram muitas dificuldades para entender essa conversão de registro e organizaram os dados referentes à questão (Tabela $3)$.

Tabela 3: Organização dos dados da $8^{\mathrm{a}}$ série X para a Questão 6.

\begin{tabular}{c|c|c}
\hline \multicolumn{3}{c}{ Tempo de uso do Computador } \\
\hline Tempo & Frequência & $\begin{array}{c}\text { Frequência } \\
\text { Relativa (\%) }\end{array}$ \\
\hline Não usa & 0 & $0 \%$ \\
\hline $\mathrm{t}<1 / 2 \mathrm{~h}$ & 1 & $4 \%$ \\
\hline $1 / 2 \leq \mathrm{t}<1$ & 2 & $8 \%$ \\
\hline $1 \leq \mathrm{t}<2$ & 7 & $27 \%$ \\
\hline $2 \leq \mathrm{t}<3$ & 4 & $15 \%$ \\
\hline $3 \leq \mathrm{t}<4$ & 6 & $23 \%$ \\
\hline $4 \leq \mathrm{t}$ & 6 & $23 \%$ \\
\hline Total & $\mathbf{2 6}$ & $\mathbf{1 0 0 \%}$ \\
\hline
\end{tabular}

Finalizadas as organizações dos dados da sala, os alunos passaram a organização dos dados da série sob a responsabilidade de cada um dos grupos, diretamente no software Excel. Como a discussão já se realizara para cada uma das questões, deixamos que os alunos trabalhassem por conta própria, apenas orientando nas dúvidas que surgiam. A atividade permitiu aos alunos perceber a vantagem em se utilizar a interatividade do software para realizar os cálculos, na medida em que, aqueles que utilizaram esse recurso na planilha inicial, apenas alteraram os valores e obtiveram, automaticamente, os índices para o novo grupo de dados. Os demais necessitaram recalcular todos os percentuais e somatórios.

A realização das atividades e as situações já descritas fazem emergir duas considerações:

$\rightarrow \mathrm{O}$ fato de os alunos trabalharem dados significativos, em alguns momentos, evidenciou o rompimento de uma visão desconexa e limitada - caracterizada pelo tratamento pontual de cada questão -, apresentando uma visão global da atividade, relacionando cada uma das questões em discussão. Por exemplo, percebendo que determinado indivíduo assinalou que não usava computador em determinada questão e, em seguida, se contradisse indicando as atividades que realizava ${ }^{29}$.

\footnotetext{
${ }^{29}$ Fato que aconteceu em alguns casos e que, para não comprometer os resultados, foram desconsiderados.
} 
Trata-se da ampliação da visão que traz muitas contribuições para análises e interpretações a serem realizadas.

$\rightarrow \mathrm{O}$ trabalho em grupo favoreceu a discussão e possibilitou o enriquecimento das atividades por meio da interação entre os próprios alunos, na medida em que aqueles que tinham maior dificuldade foram auxiliados em muitos momentos pelos alunos que tinham mais facilidade.

Concluída a organização, passamos à etapa de apresentação dos dados, que recorreu ao software SuperLogo 3.0 para a construção dos gráficos, cuja descrição dessa atividade é feita a seguir.

\subsection{Conhecendo o SuperLogo 3.0}

Visando a não tornar a linguagem LOGO um dificultador para o desenvolvimento das atividades, ou um obstáculo para a aprendizagem dos alunos, elaboramos algumas atividades de familiarização com os comandos básicos da tartaruga.

Entregamos um formulário de orientação (APÊNDICE E), no qual explicamos que a tartaruga é um cursor gráfico que aparece no centro da tela gráfica. Para fazer desenhos basta movimentá-la na tela, de modo que ela deixe traços pelo seu caminho.

Apresentamos, assim, os comandos básicos que possibilitam as ações no SuperLogo 3.0:

$\rightarrow$ PARAFRENTE $\left(\mathrm{PF}<\mathrm{n}^{\mathrm{o}}\right.$ passo $>$ ) $=$ a tartaruga anda para frente $\mathrm{o}$ número de passos indicados.

$\rightarrow$ PARATRÁS $\left(\mathrm{PT}<\mathrm{n}^{\mathrm{o}}\right.$ passos $>$ ) $=$ a tartaruga anda para trás o número de passos indicados.

$\rightarrow$ PARADIREITA $\left(\mathrm{PD}<\mathrm{n}^{\mathrm{o}}\right.$ graus $)=$ a tartaruga gira para a direita $\mathrm{o}$ número de graus indicado.

$\rightarrow$ PARAESQUERDA $\left(\mathrm{PE}<\mathrm{n}^{\mathrm{o}}\right.$ graus $>$ ) $=$ a tartaruga gira para a esquerda o número de graus indicado.

$\rightarrow$ USENADA $(\mathrm{UN})=$ a tartaruga se movimenta sem deixar traços.

$\rightarrow$ USEBORRACHA (UB) = apaga traços na tela.

$\rightarrow$ USELÁPIS (UL) = a tartaruga se movimenta desenhando os traços. 
$\rightarrow$ DESAPAREÇATAT $(\mathrm{DT})=$ a tartaruga fica invisível.

$\rightarrow$ APAREÇATAT $($ AT) $=$ a tartaruga volta a ser visível.

$\rightarrow$ PARACENTRO $(\mathrm{PC})=$ a tartaruga retorna ao centro $[0,0]$ da tela.

$\rightarrow \mathrm{TAT}=$ limpa a tela e recoloca a tartaruga no centro da tela.

$\rightarrow$ ROTULE [palavra] = aparecerá a palavra indicada no local onde a tartaruga estiver localizada.

$\rightarrow$ MUDECF $\left(\right.$ MUDECF $<n^{\circ}$ da cor $>$ ) $=$ muda cor do fundo da janela gráfica.

$\rightarrow$ MUDECL (MUDECL $<\mathrm{n}^{\circ}$ da cor $>$ ) = muda cor do lápis (traço).

$\rightarrow$ MUDECP (MUDECP $<n^{\circ}$ da cor $>$ ) $=$ muda cor do pincel (para preenchimento).

$\rightarrow$ PINTE $=$ preenche o espaço onde está a tartaruga.

$\rightarrow$ ARCO <ângulo $><$ raio $>=$ desenha um arco com o ângulo e raio digitados.

$\rightarrow$ CIRCUNFERÊNCIA $<$ raio $>=$ desenha uma circunferência com o raio digitado.

Como forma de aplicação desses comandos, solicitamos-lhes que construíssem um quadrado de lado 80, um retângulo de lados 120 e 60 e um triângulo equilátero de lados 80.

Os alunos construíram o quadrado e o retângulo com certa facilidade, mas apresentaram dificuldade na compreensão e explicitação dos comandos na linguagem da tartaruga. Apenas dois grupos conseguiram construir o triângulo equilátero. Quando questionados a respeito das dificuldades encontradas na construção, disseram que não sabiam qual o ângulo a ser utilizado. Perguntamos a um dos alunos que havia construído o triângulo como descobrir o valor do ângulo e ele respondeu:

\begin{abstract}
Pensei que um triângulo equilátero tem três ângulos iguais. Daí, lembrei que um triângulo pode ser metade de um quadrado [não este porque é equilátero]. Então ele tem a soma dos ângulos igual a metade da soma dos ângulos de um quadrado, que é 360. Dai dividi o 180 por 3 cheguei no ângulo de $60^{\circ}\left(a_{41}\right)$.
\end{abstract}

Os demais alunos fizeram a construção. No entanto, quando indicaram $60^{\circ}$ para a rotação da tartaruga o resultado obtido não foi o esperado.

Ah, mas tem uma coisa. Tem que girar a tartaruga $120^{\circ}$ porque o $60^{\circ}$ vai ficar dentro do triângulo e a tartaruga tem que virar o tanto de graus do lado de fora $\left(a_{41}\right)$. 
Partimos para o comando ROTULE, como forma de escrever na tela da tartaruga um parâmetro (palavra) indicado. Para treinar, foi solicitado que eles escrevessem a palavra MÍDIA dentro do quadrado construído anteriormente. Depois de escrito, questionamos onde a tartaruga começou a escrever e qual foi a direção tomada. Nas respostas dos alunos, verificamos que eles perceberam que a tartaruga escreve a partir de seu posicionamento e na direção de sua cabeça.

$\mathrm{Na}$ aula seguinte, trabalhamos com cores nos desenhos e linhas construídas no SuperLogo 3.0. Antes de irmos a SAI, fizemos uma retomada do que havia sido trabalhado na aula anterior e explicamos a estrutura dos comandos que seriam tratados na aula.

$\mathrm{O}$ aluno $a_{73}$, que não era considerado um "bom aluno" nos perguntou se iríamos trabalhar com o software novamente. A Professora $\mathrm{N}$ ficou indignada com o interesse do aluno, que acabou ficando sem graça perante os colegas. No entanto, na SAI desenvolveu todas as atividades, inclusive auxiliando colegas que tiveram mais dificuldades.

Propusemos a construção de uma linha e sobre essa linha dois retângulos separados por 5 passos de tartaruga, com dimensões 200 × 30 e 80 × 30, respectivamente, já pensando na estrutura de um gráfico de coluna. Além disso, solicitamos para que o primeiro fosse pintado de vermelho e o segundo de amarelo, utilizando os comandos de cores.

O trabalho com as cores evidenciou mais intenso envolvimento dos alunos com as atividades e mais efusivo interesse em entender a linguagem da tartaruga, inclusive levantando questionamentos e iniciando alguns procedimentos de raciocínio inverso para desfazer ações equivocadas. Por exemplo, ao fazer um retângulo com tamanho diferente daquele solicitado, era necessário usar o raciocínio inverso (se utilizado PF, utilizar o PT a mesma quantidade de passos; se utilizado PD, utilizar PE o mesmo ângulo) para apagar as linhas e refazê-lo.

Continuamos o trabalho, explicando os conceitos de circunferência, arco, e raio de circunferência, por meio de ações realizadas no software. Os alunos foram convidados a construir uma circunferência por meio do comando de arco, haja vista que na avaliação diagnóstica percebemos que nem todos os alunos sabiam que uma circunferência tem 360 graus. Posteriormente foram convidados a dividir a circunferência em setores de 60, 90 e 210 graus e pintar cada um de uma cor, ja pensando no gráfico de setores.

Por fim, apresentamos o comando REPITA que é usado quando se quer efetuar uma mesma ação, ou sequência de ações, um determinado número de vezes. São necessários dois parâmetros, um número e uma lista: 
$\rightarrow$ REPITA $<$ numero $><\operatorname{lista}^{30}>=$ repete o número de vezes indicado a lista de comandos indicada.

Como exemplo, solicitamos que construíssem o quadrado do início da atividade, usando o comando repita. Os alunos acharam interessante a ideia, mas tiveram mais dificuldades, pois expressaram que, na maioria dos casos, não conseguiram construir o quadrado pela necessidade de pensar em dois ou mais comandos simultaneamente, ao contrário da construção sem a utilização do repita.

\subsection{Construindo Gráficos}

Antes de iniciarmos a descrição das atividades, cabem alguns esclarecimentos.

Apesar de o SuperLogo 3.0 ser um software procedimental, no qual é possível construir procedimentos por meio dos comandos apresentados no item 5.5 e utilizá-los para o desenvolvimento das atividades, nosso trabalho não está fundamentado na construção de procedimentos para a construção dos gráficos (exceto para os eixos). Na verdade, optamos por este software por acreditarmos que, tendo em vista seu caráter dinâmico e direto de apresentar graficamente os comandos digitados, pode contribuir para a tomada de consciência acerca das representações gráficas, na medida em que, ao se obter um resultado gráfico diferente daquele esperado, propiciamos ao aluno a vivência da espiral da aprendizagem. Nesse contexto, tanto o modo direto quanto a utilização de procedimentos contribuiria com os objetivos do trabalho. Porém, pela maior complexidade que envolve o trabalho com os procedimentos, o modo demandaria mais tempo para as construções gráficas, flexibilidade de que não dispúnhamos. Dessa forma, o trabalho no modo direto mostrou-se mais conveniente à proposta, não sendo descartada, no entanto, a possibilidade de realizarmos (num próximo momento) atividades envolvendo procedimentos.

Além disso, cabe esclarecer que havíamos pensado em realizar a construção dos gráficos de forma similar à organização dos dados, isto é, todos os grupos construiriam os gráficos da sala e depois os gráficos da série pela qual ficou responsável. No entanto, isso não foi possível em virtude da desativação da SAI da Escola A, para fins de reforma. Em consequência, tivemos de fazer algumas adaptações nas atividades realizadas.

Firmamos parceria com uma unidade local da UNESP com o objetivo de utilizar o Laboratório Didático de Informática desta instituição para finalizarmos as atividades

\footnotetext{
${ }^{30}$ Uma sequência de comandos a serem executados pela tartaruga.
} 
do projeto. Por necessitarmos transportar os alunos da Escola A até a UNESP ${ }^{31}$, também estabelecemos parceria com a Secretaria Municipal de Educação da cidade, onde está localizada a Escola A que, gentilmente, cedeu transporte para os alunos.

Em razão da alteração do espaço da pesquisa, resolvemos que cada grupo construiria os gráficos de sua série e o G. 3 (composto de 6 alunos) foi dividido em dois, de forma que uma parte dele ficou responsável por construir os gráficos referentes aos alunos da $8^{\mathrm{a}}$ série $\mathrm{X}$.

Finalmente, cabe esclarecer que não foram construídos gráficos para todas as tabelas. As questões que envolveram tabelas de dupla entrada foram analisadas ${ }^{32}$ utilizando apenas os dados nela organizados, tendo em vista que, conforme Flores e Moretti (2005), a tabela é

[...] uma forma de representação gráfica que parece simples e direta. Por isso, o recurso a ela é comum e frequente no ensino de matemática. Trata-se das representações gráficas do tipo tabelas, ou seja, daqueles cuja disposição é feita sobre linhas e colunas; do tipo gráficos cartesianos; ou ainda, dos gráficos de barras. Porém, esta simplicidade de acesso às informações, a homogeneidade visual e a forma organizada de distribuição de dados, só são aparentes. Fatores diversos como, por exemplo, aqueles requeridos na organização representacional e visual, bem como aqueles ligados aos processos cognitivos, podem interferir tanto na leitura e análise dos dados dispostos neste tipo de representação, como na própria construção e organização dos dados (FLORES; MORETTI, 2005, p. 5).

Nossa opção está fundamentada, ainda, na afirmação de Duval (2002 apud FLORES; MORETTI, 2005), de que ler tabela de dupla entrada não é tarefa fácil, porque não podemos lê-la pontualmente e necessitamos relacionar aspectos pontuais dos cruzamentos com uma visão global dos dados. No gráfico, isso pode se tornar mais difícil, tendo em vista que o aluno deverá relacionar os dados para poder construir o registro correspondente.

Esclarecidos esses aspectos sobre o desenvolvimento do trabalho, passamos à descrição da etapa de construção dos gráficos. Considerando o tempo restrito para conclusão do trabalho, antes de o iniciarmos no Laboratório de Informática, realizamos algumas atividades em sala de aula, durante as quais foram apresentados e discutidos os aspectos conceituais acerca dos tipos de variáveis e gráficos, visando a fornecer subsídios para os procedimentos de construção dos eixos, além de elucidar conceitos estatísticos fundamentais, haja vista que eles foram dados prontos, mas os alunos necessitam compreender os comandos necessários para sua construção. A seguir, apresentamos essa discussão

\footnotetext{
${ }^{31}$ Solicitamos autorização dos pais e da direção da Escola A.

${ }^{32}$ Conforme será descrito no item de análise ao final deste capítulo.
} 


\subsubsection{Classificação das Variáveis}

Segundo Castanheira (2006), podemos definir variável como uma característica que observamos numa pesquisa e que pode assumir diferentes valores. Neste contexto, cada uma das características tratadas no questionário de coleta de dados representa uma variável.

Elas podem expressar qualidades, categorias ou atributos e, normalmente, não podem ser expressas em valores numéricos, as qualitativas, ou expressar valores numéricos, as quantitativas. "Resumidamente, VARIÁVEIS QUANTITATIVAS são medições e contagens. VARIÁVEIS QUALITATIVAS descrevem pertinência ao grupo" (CASTANHEIRA, 2006, p. 44).

Estas podem ainda ser classificadas em dois diferentes grupos: nominais e ordinais.

A VARIÁVEL QUALITATIVA NOMINAL permite somente a classificação de dados, como é o caso da variável sexo e do ramos de atividades de uma empresa, entre outras. A VARIÁVEL QUALITATIVA ORDINAL permite que se estabeleça uma ordem nos seus resultados como, por exemplo, o grau de instrução ou o status (classe) social de um grupo de pessoas (CASTANHEIRA, 2006, p. 43).

Em outras palavras, se as variáveis apresentam uma ordenação natural, indicando intensidades crescentes de realização, elas serão chamadas qualitativas ordinais, caso contrário, serão qualitativas nominais (MAGALHAES; LIMA, 2004).

As variáveis quantitativas também podem ser classificadas em dois grupos diferentes: discretas e contínuas.

A VARIÁVEL QUANTITATIVA DISCRETA permite relacionar todos os
possíveis valores que ela pode assumir. Além disso, apresenta lacunas entre os
valores que pode assumir, tais como número de peças defeituosas produzidas por
determinada máquina ou o número de filhos dos empregados de determinada
empresa. A VARIÁVEL QUANTITATIVA CONTÍNUA, por sua vez, pode
assumir infinitos valores dentro de um intervalo de números reais, de tal forma que
não podemos previamente relacionar todos os possíveis resultados a encontrar na
pesquisa. Como exemplo, podemos citar a altura (estatura) dos empregados de uma
fábrica ou as diferentes temperaturas registradas ao longo de certo tempo em uma
localidade (CASTANHEIRA, 2006, p. 43-44).

A grosso modo, podemos dizer que as variáveis quantitativas discretas são provenientes de contagens, assumindo assim valores inteiros num conjunto finito e enumerável. Por outro lado, as variáveis quantitativas contínuas assumem valores em intervalos dos números reais - portanto convém agrupar os dados em classes ou intervalos-, normalmente provenientes de medições (MAGALHÃES; LIMA, 2004).

Cabe, ainda, salientar que uma variável pode ter classificações diferentes, de acordo com o tratamento dado a ela. Por exemplo, se pensarmos na variável peso ela deveria 
ser classificada como quantitativa. No entanto, se a tratarmos em três classes (por exemplo, magros, normais e obesos de acordo com o peso), ela caracterizará uma variável qualitativa. Neste contexto, segue abaixo a classificação das variáveis tratadas em cada uma das questões do instrumento diagnóstico, de acordo com a discussão realizada em sala de aula com os alunos.

Quadro 9: Classificação das variáveis da investigação

\begin{tabular}{|c|l|l|}
\hline Questão & \multicolumn{1}{|c|}{ Variável } & \multicolumn{1}{|c|}{ Classificação } \\
\hline \multirow{2}{*}{01} & Idade & Quantitativa Discreta \\
\cline { 2 - 3 } & Sexo & Qualitativa Nominal \\
\cline { 2 - 3 } & Série & Quantitativa Discreta \\
\hline 02 & Itens que tem & Qualitativa Nominal \\
\hline 03 & Itens que usa & Qualitativa Nominal \\
\hline 04 & Locais de uso do computador & Qualitativa Nominal \\
\hline 05 & Tipo de uso do computador & Qualitativa Nominal \\
\hline 06 & Tempo de uso do computador & Quantitativa Contínua \\
\hline 07 & Tipo de uso do celular & Qualitativa Nominal \\
\hline
\end{tabular}

Os itens relacionados à idade, sexo e tempo de uso do computador não geraram dúvidas, nem discussões. No entanto, muito se discutiu a respeito das demais variáveis, no concernente a serem classificadas como quantitativas discretas ou qualitativas nominais. Ao final, chegamos à definição apresentada no quadro 9 , com os seguintes argumentos.

$\rightarrow$ A variável série, apesar de caracterizar um pertencimento a um grupo (a série a qual cada aluno está cursando) foi considerada em nosso instrumento como uma variável relacionada com a idade e, dessa forma, deve ser classificada como quantitativa.

$\rightarrow$ As variáveis das questões 2, 3, 4, 5 e 7, apesar de os alunos se confundirem alegando que estávamos contando cada uma das categorias, indicam a pertinências dos alunos a cada uma delas. Dessa forma, foram classificadas como qualitativas.

Determinadas as classificações das variáveis, passamos para a discussão dos tipos de gráficos. 


\subsubsection{Tipos de Gráficos}

É certo que existe uma infinidade de formas gráficas para representação de dados, cabendo até mesmo um estudo aprofundado visando à discussão das características e funcionalidades de cada um deles. No entanto, esse não é objetivo deste trabalho e, portanto, nos limitaremos a discutir as formas gráficas mais usuais, presentes nos registros encontrados nas diversas mídias atuais: gráfico de colunas, gráfico de barras, gráfico de setores, e histograma ${ }^{33}$.

Cabe salientar que, de maneira geral e, ao contrário da questão dos tipos de variáveis, não tivemos muitas dúvidas ou discussões no momento em que abordamos este item. Na verdade não nos preocupamos muito, visto que nosso interesse maior era o entendimento da estrutura de cada tipo gráfico, bem como alguns princípios de funcionalidade de cada um.

\subsubsection{O Gráfico de Colunas}

O gráfico de colunas utiliza o plano cartesiano, distribuindo os valores da variável no eixo horizontal (das abscissas) a partir da origem (interseção dos eixos horizontal e vertical) e as frequências no eixo vertical, sendo crescente também a partir da origem (MAGALHÃES; LIMA, 2004). Construídos os eixos, cada valor da variável é representado por meio de retângulos (colunas) cujas alturas correspondem a sua frequência.

"Este tipo de gráfico se adapta melhor às variáveis quantitativas discretas ou qualitativas ordinais" (MAGALHÃES; LIMA, 2004, p. 13).

\subsubsection{O Gráfico de Barras}

É semelhante ao anterior, porém, os retângulos são dispostos na horizontal (CASTANHEIRA, 2006). Devemos salientar a diferença dos dois gráficos de forma a explicitar as particularidades e contribuições de cada tipo. No gráfico de coluna, o eixo horizontal traz os valores da variável, enquanto, o vertical apresenta as informações

\footnotetext{
${ }^{33}$ Inicialmente pensamos em trabalhar com o gráfico de linhas. No entanto, em virtude da complexidade dos conceitos trigonométricos que envolveriam sua construção na linguagem LOGO (funções inversas de seno e cosseno, por exemplo), tendo em vista que estamos trabalhando com alunos da $8^{\text {a }}$ série do EF, optamos por utilizar o histograma, que também permite o tratamento de dados contínuos, de forma mais simples, não complicando o trabalho.
} 
numéricas da freqüência. No caso do gráfico de barras, isso se inverte, ficando as variáveis representadas no eixo vertical e as frequências no eixo horizontal. Essas características, na maioria das vezes, tornam-se mais visuais o primeiro tipo (ARAUJO; FLORES, 2007).

[...] muitas vezes o aluno para ler este gráfico [barras] o transforma em um gráfico de coluna, transferindo os eixos, isso não descaracteriza o gráfico, mas podemos afirmar que os alunos já estão conseguindo transitar em mais de um registro de representação (ARAUJO; FLORES, 2007, p. 11).

\subsubsection{O Gráfico de Setores}

O gráfico de setores, popularmente conhecido como gráfico de pizza, também chamado de gráfico de disco ou diagrama circular, é uma representação de um círculo divido em setores proporcionais (em graus) a cada uma das frequências relativas das classes da variável (MAGALHÃES; LIMA, 2004).

Esse tipo de gráfico é muito útil, quando desejamos comparar cada valor das classes da variável com o valor total (CASTANHEIRA, 2006). No entanto, não deve ser utilizado quando se tem por objetivo comparar classes, cuja totalidade não contabiliza cem por cento, seja por falta de informações (alguma classe é desconhecida) ou pelo fato de as classes da variável não serem disjuntas, isto é, um indivíduo da população pode estar presente em mais de uma classe. Esse é o caso da questão 4 de nosso instrumento de coleta de dados (locais de uso do computador).

\subsubsection{O Histograma}

O histograma possui eixos similares aos do gráfico de colunas e consiste em retângulos contíguos com base nas faixas de valores da variável, com altura igual à sua frequência ${ }^{34}$.

Esse tipo de gráfico "é muito utilizado para representar a distribuição de frequências cujos dados foram agrupados em classes ou intervalos de mesma amplitude" (CASTANHEIRA, 2006, p. 36), predominantemente variáveis quantitativas contínuas, como no caso da questão 6 (tempo de uso do computador).

\footnotetext{
${ }^{34} 23$ Alguns autores utilizam a ideia de densidade, determinada pelo quociente da área pela amplitude da faixa, para determinar a área de cada coluna, como Magalhães e Lima (2004). No entanto, como trabalhamos com alunos da $8^{\mathrm{a}}$ série do $\mathrm{EF}$, optamos por adotar a frequência da faixa como referência para os retângulos.
} 


\subsubsection{A construção dos eixos para os gráficos}

Os eixos ${ }^{35}$, conforme descrito no capítulo de concepção da sequência, estão pautados no desenvolvimento do raciocínio proporcional, que, segundo Lamon (1993 apud COSTA, 2007), “implica pensar em termos relativos, ou seja, considerar a razão como uma entidade distinta das duas quantidades que a compõem".

Quando trabalhamos a relação amplitude real x amplitude em passos de tartaruga e escala real x escala em passos de tartaruga, o raciocínio proporcional é tratado por meio de situações de ampliação e redução, isto é, existe uma relação que se deve preservar, uma razão, em todas as circunstâncias, inclusive nas construções das barras e colunas de frequência dos gráficos.

Assim, explicamos para os alunos a estrutura do comando a ser indicado na linha de comandos do SuperLogo 3.0, de forma a se obter o eixo pretendido:

$\rightarrow$ O tipo de gráfico: eixobarra, eixocoluna, eixohistograma.

$\rightarrow$ A amplitude do eixo numérico: o valor máximo do eixo numérico (seja ele horizontal ou vertical, de acordo com o tipo de gráfico a ser construído).

$\rightarrow$ A amplitude em passos de tartaruga: a amplitude do eixo numérico multiplicada pela razão escolhida.

$\rightarrow$ A escala: aqui entendida como a amplitude dos intervalos para divisão do eixo numérico.

$\rightarrow$ A escala em passos de tartaruga: a escala multiplicada pela razão estabelecida.

Em geral, os alunos optaram pela razão 10 (dez), na medida em que os cálculos se tornavam mais fáceis. No entanto, tendo em vista que a tela do SuperLogo 3.0 é limitada em 500 passos de tartaruga a partir do centro, em alguns casos, a razão necessitava ser repensada, enriquecendo ainda mais o trabalho de construção dos gráficos.

Podemos pensar que uma razão um para dez pode não caracterizar consciência por parte do aprendiz, que é capaz de efetuar o raciocínio sem, necessariamente, utilizar proporção, utilizando, por exemplo, relações e cálculos mentais, pautando-se na relação de invariância entre as duas grandezas, sem perceber a variação conjunta delas, chamada covariância (COSTA, 2007). Além disso, o fato da utilização de uma única razão em todas as

\footnotetext{
${ }^{35}$ Exceto para o gráfico de setores que não necessita de eixos.
} 
situações reduz as possibilidades de desenvolvimento do raciocínio proporcional. No entanto, a necessidade de se utilizarem outras razões (por exemplo, um para cinco) trouxe significativas contribuições para a tomada de consciência sobre a proporção envolvida e necessária à compreensão de gráficos cartesianos. Ademais, esse fato enriqueceu a percepção e a compreensão da relação existente entre eixos e barras/colunas de frequências, na medida em que foi necessário que o indivíduo compreendesse de fato a referida relação para a construção correta do gráfico, o que sem o raciocínio proporcional, ficaria implícito e/ou subentendido, mas de difícil acesso ao pesquisador/professor.

\subsubsection{Locais de Uso do Computador: O Gráfico de Barras}

Iniciamos a aula, relembrando qual era a classificação da variável em questão qualitativa nominal. Depois passamos à discussão de que tipo de gráfico poderia ser utilizado.

O G. 6 sugeriu um gráfico de setores, tendo em vista que cada um dos locais tinha um percentual que poderia ser representado por um setor. Então, solicitamos para que eles revissem as anotações a respeito das discussões sobre os tipos de gráfico e suas aplicações. Perceberam que o gráfico de setores não é o mais adequado, tendo em vista que os alunos investigados puderam indicar mais de um local de uso do computador e optamos por fazer a análise considerando percentuais de cada local em relação ao total de alunos da sala ${ }^{36}$. Dessa forma, passamos à discussão de outra maneira de apresentar os dados. Sugerimos o gráfico de barras e eles concordaram.

O G. 3 foi dividido por ser muito grande e pela necessidade de realizarmos as análises dos dados dos alunos da própria sala, possibilitando as análises posteriores. Assim, as alunas $a_{34}, a_{35}$ e $a_{36}$ ficaram responsáveis pela construção dos gráficos da $8^{\mathrm{a}}$ série $\mathrm{X}$.

Os alunos demonstraram muita dificuldade para entender o raciocínio proporcional necessário à construção dos gráficos. Alegaram profunda incompreensão por não entender muito bem o "funcionamento". Para ilustrar, apresentamos o comando do G. 6 (2 ano do EM), em que a razão entre amplitude (1/5) e escala (1/10) não foi preservada, gerando o eixo mostrado na Figura 4:

\footnotetext{
${ }^{36}$ Poderíamos ter pensado em outra maneira de analisar os dados, considerando o total de respostas obtidas com a população investigada e calcular percentuais a partir disso.
} 
eixobarra $60300550\left(a_{63}\right)$

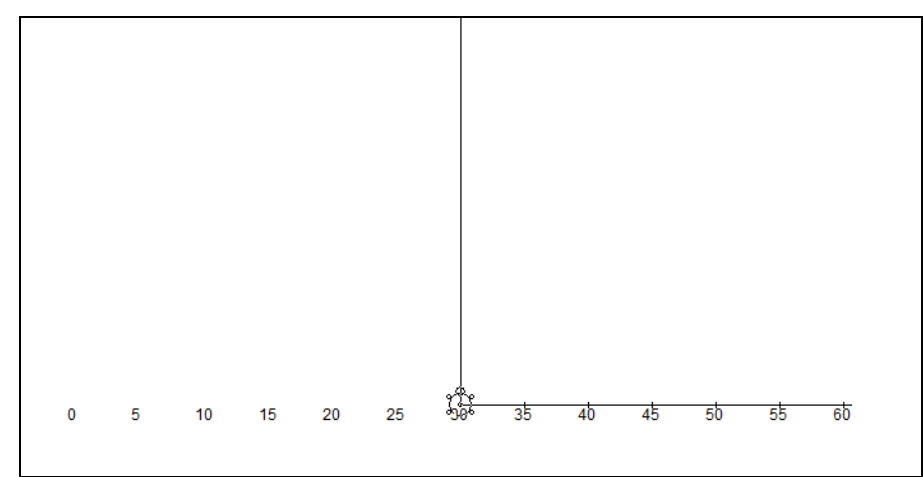

Figura 5: Eixo do gráfico de barras com erro de proporcionalidade

Diante desse tipo de situação, os grupos chamavam pelo professor/pesquisador questionando o que havia acontecido. Nós, enquanto mediadores, devolvíamos a pergunta solicitando que eles refletissem a respeito e verificassem se estava correto, de forma a buscarem no milieu de referência, informações e conceitos que mostrassem o equívoco.

Em alguns momentos, os alunos alegavam que "o problema era com o software", mas, na verdade, referiam-se ao procedimento de construção dos eixos. Contudo, esse argumento era facilmente derrubado quando eles percebiam que o grupo ao lado estava construindo o gráfico sem nenhum problema e de uma maneira parecida com a deles. Tal situação os instigava e, em alguns momentos, procuravam o auxílio dos colegas, perguntandolhes como haviam construído o eixo, de forma a comparar com o comando que eles indicaram na linha de comando do SuperLogo. Dessa maneira, as dificuldades nas construções dos eixos foram superadas por eles mesmos.

A necessidade do raciocínio proporcional era constante, porque, para a construção das barras, a relação de proporcionalidade pela razão estabelecida, também era necessária. O exemplo abaixo é do G. 2 que, utilizando uma razão de 5, cometeu um erro ao indicar a quantidade de 62 alunos, sem considerar a razão estabelecida. No entanto, ao perceber que o resultado obtido não correspondia ao esperado, tendo em vista que os 62 passos de tartaruga indicaram algo próximo de 12 alunos no eixo horizontal do gráfico (Figura 6), conseguiu refletir sobre o resultado e depurar o erro, sem a intervenção do professor, indicando o valor de 310 passos de tartaruga, valor correto para representar os 62 alunos. 


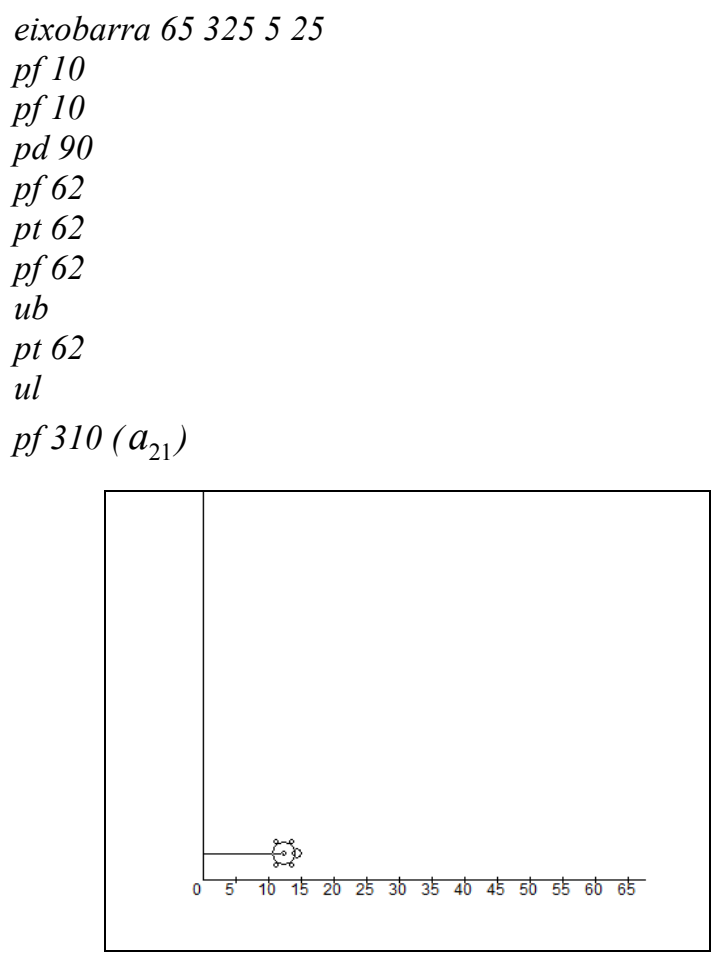

Figura 6: Resultado de erro de comando

Este tipo de erro foi o que evidenciou a tomada de consciência por parte dos alunos da relação entre eixo numérico (neste caso das abscissas) e o tamanho das barras de frequência, na medida em que indicavam um comando na expectativa de uma linha de determinado tamanho, expectativa decorrente, muito provavelmente, pela amplitude total indicada na construção dos eixos. Após a execução do comando pela tartaruga, percebiam que o resultado obtido era diferente do esperado.

Além disso, os grupos G. 1 e G. 3 tiveram problemas ao utilizar valores na amplitude que não eram múltiplos da escala utilizada, comprometendo a relação entre escala e amplitude. Inicialmente, os alunos apresentaram muita dificuldade na compreensão do erro. Então explicamos que estavam dividindo o eixo em partes iguais e a tartaruga só conhecia número inteiro. A partir da explicação, os alunos dos dois grupos entenderam o erro, conforme exemplificado pelos comandos abaixo, do G. 3 . 
eixobarra 58290525

repita não aceita " 11.6 " como parâmetro de entrada em eixobarra

[repita (:amplitudepassos / :escalapassos) [pf :escalapassos marque] pf (

:amplitudepassos / :escalapassos)]

tat

eixobarra 58290550

repita não aceita " 5.8 " como parâmetro de entrada em eixobarra

[repita (:amplitudepassos / :escalapassos) [pf :escalapassos marque] pf(

:amplitudepassos / :escalapassos)]

tat

eixobarra $60300525\left(a_{33}\right)$

Por se tratar da primeira atividade desenvolvida no SuperLogo $3.0^{37}$, bem como com o procedimento dos eixos, tivemos alguns problemas:

$\rightarrow$ utilização de um eixo maior que 500 passos de tartaruga (Figura 6). Acreditamos que por julgarem mais simples o estabelecimento de uma razão de um para dez, todos os grupos optaram por ela. No entanto, alguns grupos (como foi o caso do grupo 3) tinham dados que necessitavam de um eixo maior que 500 passos de tartaruga, o que ocasionou o erro.

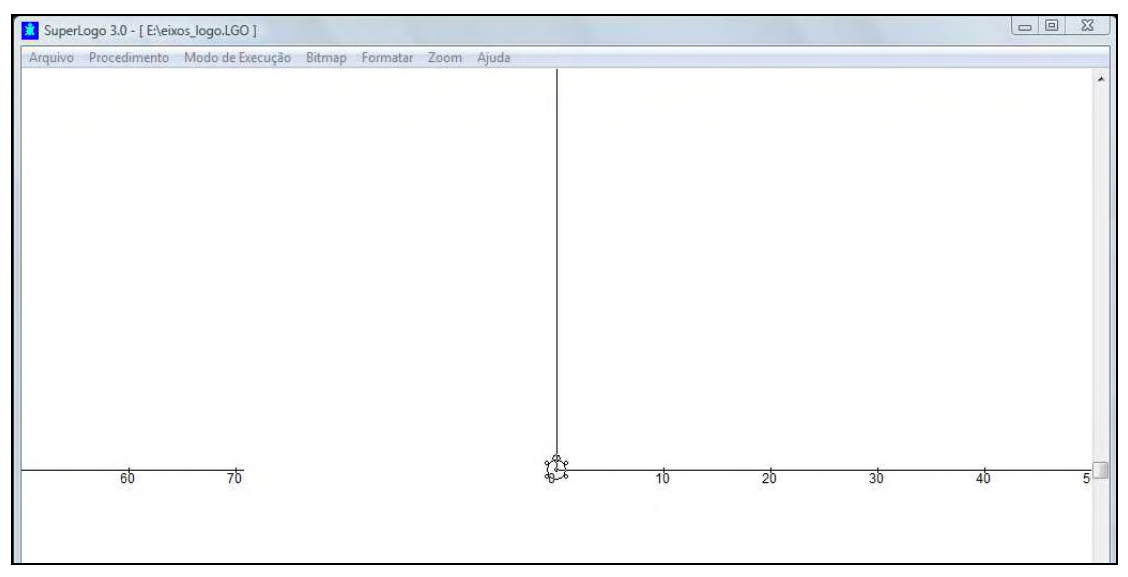

Figura 7: Utilização de um eixo de 700 passos de tartaruga

$\rightarrow$ utilização do comando PARACENTRO ao final da construção sem o comando USENADA antes, gerando uma linha sobre o gráfico a qual não foi possível apagar. Tivemos que salvar os comandos dos alunos como um procedimento, de forma que eles não tivessem que refazer os gráficos. Acreditamos que o problema seja decorrente da restrita

\footnotetext{
37 Antes disso, eles apenas haviam se familiarizado com alguns comandos, conforme discutimos no item
} Conhecendo o SuperLogo 3.0. 
familiaridade dos alunos com uma linguagem de programação. Como eles mesmos disseram:

Professor, não tem um $\mathrm{Ctrl}^{38}\left(a_{33}\right)$.

$\rightarrow$ quando rotulavam em local inadequado, ao utilizar a ferramenta borracha para apagar, a palavra ficava com as letras brancas, e não na cor da barra (ou várias barras) (Figura 8).

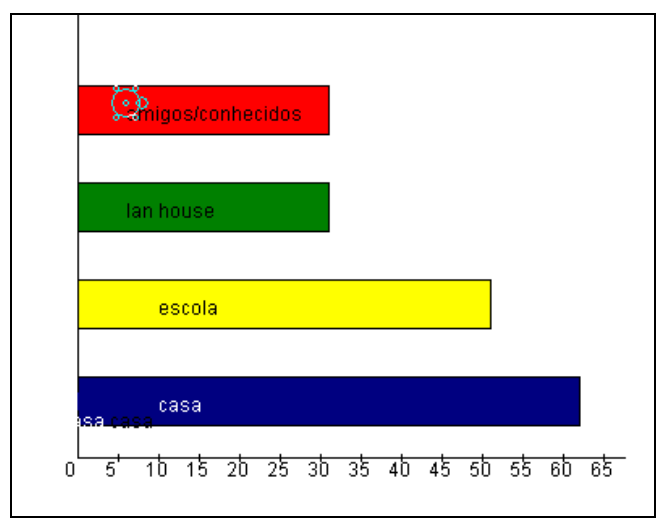

Figura 8: Gráfico da $6^{\circ}$ série rotulado/apagado com a palavra casa várias vezes

$\rightarrow$ um computador (G. 4) apresentou problemas para pintar as barras, quando os alunos dando os comandos de forma correta, o software não atendia. Assim, salvamos os comandos como um procedimento e reconstruímos o gráfico, visando a não comprometer as atividades do grupo.

$\rightarrow$ os grupos G. 2, G. 3 e G. 4 rotularam sobre as barras, ocasionando uma apresentação um pouco feia e comprometendo a leitura da representação (Figura 8). Além disso, nenhum grupo utilizou o comando DESAPAREÇATARTARUGA, de forma que a tartaruga não comprometesse a apresentação dos dados. Alguns grupos (G. 3, G. 6 e G. 7) utilizaram o PARACENTRO, de forma que a tartaruga ficasse na interseção dos eixos ortogonais.

\footnotetext{
${ }^{38}$ Comando para desfazer tarefas em vários aplicativos computacionais.
} 


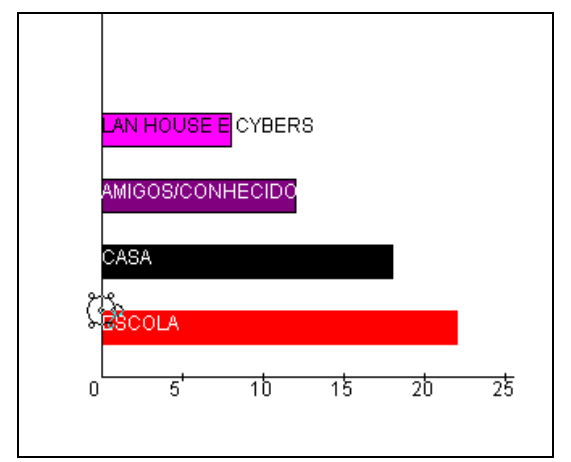

Figura 9: Gráfico da $8^{\mathrm{a}}$ série $\mathrm{X}$ rotulado sobre as barras com a tartaruga fora do centro

Os grupos G. 1 e G. 3 apresentaram muita dificuldade e resolvemos dar mais atenção a eles, de forma que pudessem avançar, como os demais.

\subsubsection{Distribuição das idades dos alunos: o Gráfico de Colunas}

Iniciamos a aula novamente, tratando do tipo de variável em questão, quantitativa discreta e do tipo de gráfico a ser utilizado. Os alunos sugeriram o gráfico de colunas, com que concordamos.

Foi necessário relembrar a estrutura do comando de chamada do procedimento para a construção dos eixos, salientando que, neste momento, o tipo de gráfico era outro e, portanto, mudaria no nome do eixo.

As dificuldades com o raciocínio proporcional, apesar de terem diminuído, permaneceram, conforme exemplificado no G. 3, confundindo a razão $1 / 10$ com a razão 1/5.

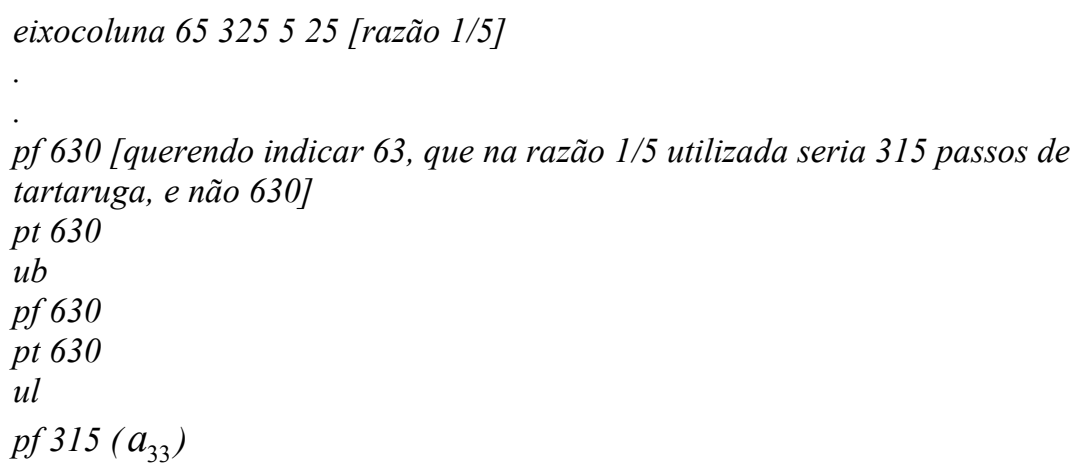




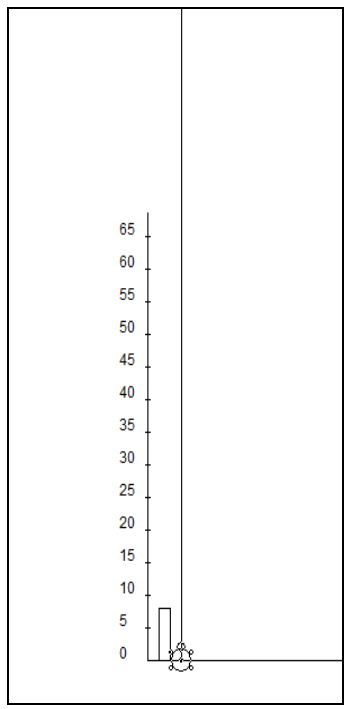

Figura 10: Erro decorrente dos comandos apresentados pelo G. 3 (descritos acima)

As atividades transcorreram de forma bastante similar às do gráfico de barras. Entretanto, ficou evidente a familiaridade dos alunos com os comandos do SuperLogo 3.0, o que facilitou a construção dos gráficos.

Dando mais atenção aos dois grupos que tiveram maior dificuldade no dia anterior, eles avançaram e conseguiram concluir as atividades.

Por fim, destacamos a forma como os grupos conseguiram rotular as colunas, demonstrado no gráfico, construído pelo G. 6, para os dados de 76 alunos da $6^{\text {a }}$ série da Escola A (Figura 11).

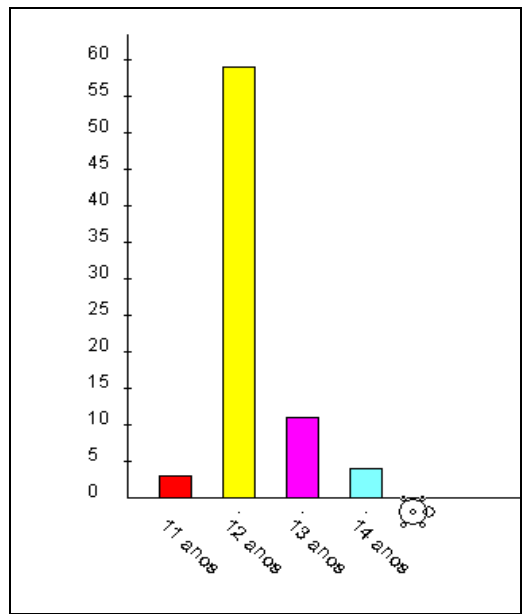

Figura 11: Colunas rotuladas do lado de fora e em diagonal 


\subsubsection{Distribuição entre Meninos e Meninas: $O$ Gráfico de Setores}

Como nos outros casos, iniciamos a aula discutindo o tipo de variáveis qualitativa nominal - e uma possível forma gráfica para representar os dados. Pelo tipo de variável e por ainda não termos feito nada envolvendo o gráfico de setores, o alunos sugeriram que o utilizássemos.

Passamos então à discussão de sua estrutura no SuperLogo 3.0.

É só fazer um circulo e dividir em duas partes. Uma para os meninos e outra para as meninas $\left(a_{41}\right)$.

No entanto, perguntamos como descobriríamos o ângulo a ser considerado para cada uma das partes. A pergunta gerou muitas discussões.

Tentamos auxiliar na organização do raciocínio. Partimos da seguinte questão: Quantos graus tem um círculo todo? A resposta foi $360^{\circ}$, até mesmo porque trabalhamos essa propriedade no item Conhecendo o SuperLogo 3.0. Sabíamos, portanto, quanto era no total (100\%). Questionamos então qual o percentual que gostaríamos de saber. Cada grupo disse um índice diferente. Então utilizamos uma suposição de 40\% e 60\%, tendo em vista que a soma das suas partes teriam de totalizar o $100 \%$. Como poderíamos resolver isso? Uma das alunas perguntou:

$$
\text { Isso não é regra de três, professor? }\left(a_{52}\right) \text {. }
$$

Respondemos afirmativamente e questionamos a forma de resolução de uma regra de três.

$$
\text { Faz uma fração e iguala, colocando x no número desconhecido }\left(a_{52}\right) \text {. }
$$

Solicitamos-lhe que resolvesse na lousa. E ela fez da seguinte maneira:

$$
\frac{100}{40}=\frac{360}{x} \Rightarrow 100 x=14400 \Rightarrow x=\frac{14400}{100} \Rightarrow x=144
$$

Assim, os $40 \%$ são $144^{\circ}$ e o restante dos $360^{\circ}$ são os $60^{\circ}$ que falta. O raciocínio e os cálculos dela estavam corretos. Apenas alguns termos não. Explicamos que, na verdade, trata-se de um raciocínio análogo ao que fazíamos para a construção dos gráficos de barra e coluna, utilizando uma razão, visando a manter sempre a mesma proporção. A diferença estava nos termos a serem considerados.

Ficou claro que nem todos os alunos entenderam os conceitos e ideias discutidos, mas decidiram que iriam construir os gráficos. 
Como já esperávamos, não houve dificuldade alguma quanto à construção dos gráficos. O problema era determinar o ângulo. Percebemos que os alunos se ajudavam e, aos poucos, aqueles que apresentavam mais dificuldades foram compreendendo a ideia.

Como o processo de construção desse gráfico foi mais rápido e envolvia um raciocínio diferente, solicitamos que todos os grupos construíssem o gráfico da $8^{\mathrm{a}}$ série $\mathrm{X}$, além da série de responsabilidade de cada um dos grupos, respectivamente.

\subsubsection{Número de Horas de uso do Computador: O Histograma}

De maneira semelhante às aulas anteriores, desencadeamos os trabalhos, discutindo o tipo de variável, quantitativa contínua, e o gráfico a ser utilizado. Os alunos olharam as anotações do caderno, relembrando que o histograma é indicado para os dados apresentados em intervalos contíguos.

Passamos, então, à construção do gráfico, iniciando pelo comando para a construção do eixo.

Ao contrário dos demais, o histograma apresenta os dois eixos numéricos, um representando os intervalos da variável em questão e outro representando as frequências de cada um dos intervalos. Isso causou certa estranheza por parte dos alunos, visto que estavam acostumados com outro tipo de estrutura. Tratamos de estabelecer as relações entre a forma como foi estruturada a questão no instrumento de coleta de dados e na tabela de organização, no intuito de que eles percebessem a particularidade dos dados em questão, comparados com os demais. Aparentemente apenas alguns perceberam. No entanto, deixamos todos iniciarem a construção do histograma, tendo clareza que em algum momento se deparariam com alguma inconsistência, em razão do desconhecimento de qual era o tamanho de cada um dos intervalos para a construção da base dos retângulos. Dessa forma, caso houvesse compreensão, esse questionamento seria imediato, caso contrário não conseguiriam construir os gráficos. Isso evidenciou que a relação entre intervalos dos dados nas tabelas e os intervalos no eixo horizontal não estava estabelecida, já que iniciaram a construção do gráfico de forma equivocada e, quando perceberam essa relação, reiniciaram a construção. 


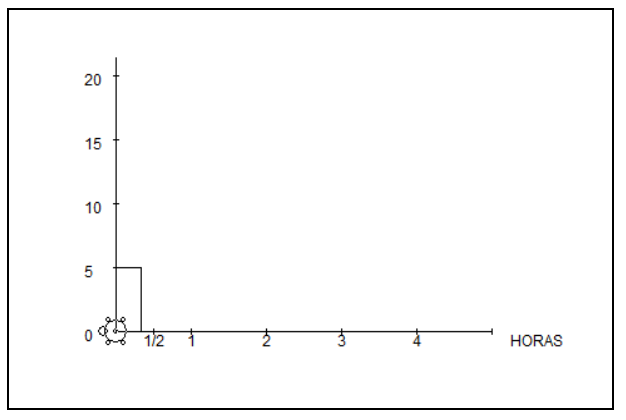

Figura 12: Erro na construção do histograma

De maneira geral, a única dificuldade dos alunos foi estabelecer essa relação inicial. A partir disso, construíram o gráfico tranquilamente. Todavia, quando fomos analisar as construções, detectamos algo que chamou a atenção. Dentre os histogramas construídos encontramos uma construção finalizada errada (o único gráfico errado dentre todos os gráficos construídos). Os alunos se esqueceram da proporção estabelecida no eixo numérico (unidade $\mathrm{x}$ passos de tartaruga), não manifestando a relação barra-eixo. Dessa forma, perguntamos-lhes se comparando a tabela e o histograma, era possível concluir que os dois representavam os mesmos dados. Nesse momento, eles perceberam o equívoco e, então, solicitamos que o histograma fosse refeito.

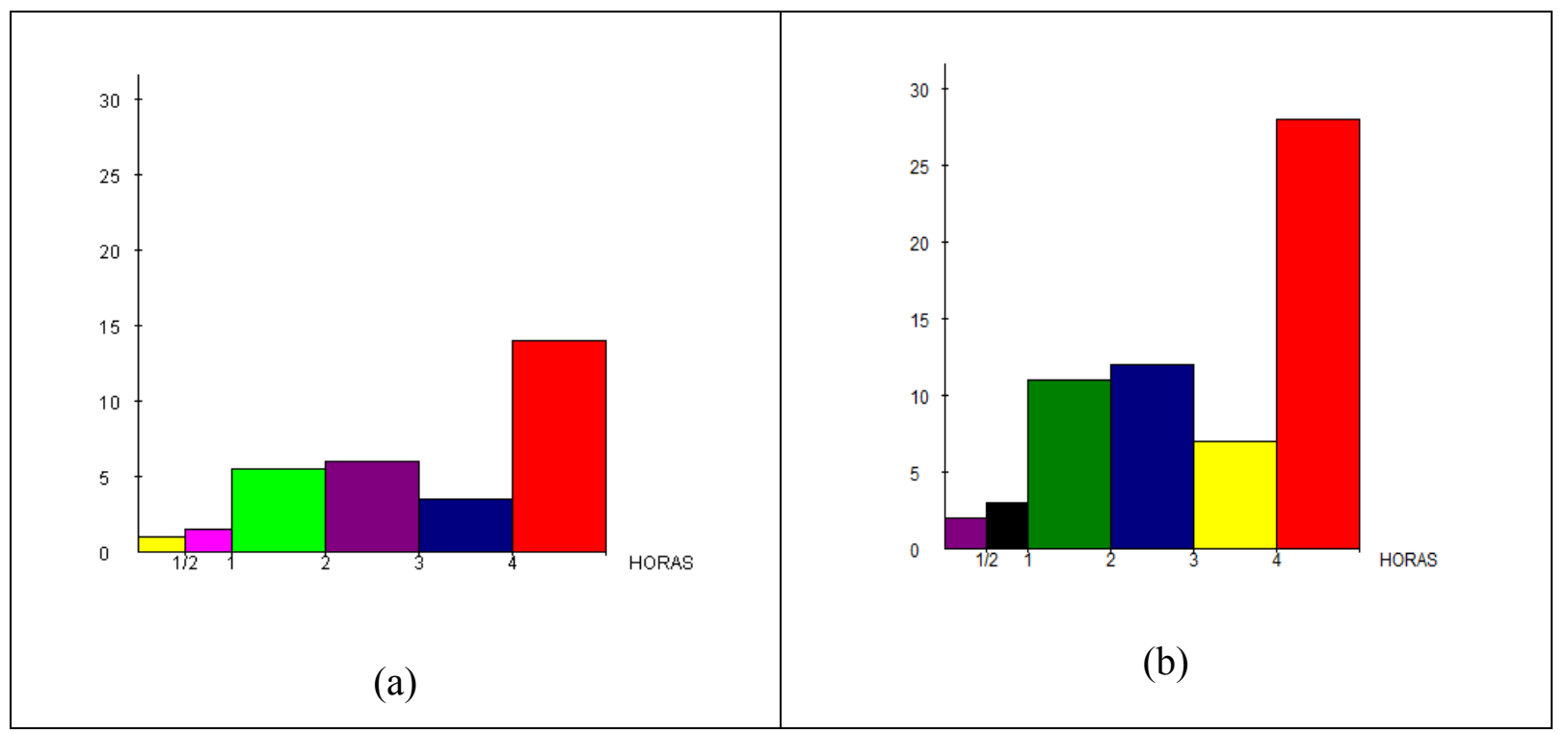

Figura 13: Histograma do G. 6 a partir dos dados do $2^{\circ}$ ano do EM (a) errado e (b) corrigido

A atividade conduziu-nos às seguintes conclusões:

$\rightarrow$ A necessidade de se observarem valores nos dois eixos representa um dado dificultador. Acreditamos que, assim como na tabela de dupla 
entrada, a construção do histograma exigiu a visão global, relacionando os dois eixos. Talvez essa seja a habilidade que os alunos precisam desenvolver.

$\rightarrow \mathrm{O}$ fato de um grupo ter construído um histograma errado revela que a relação eixo x coluna (ou barra, no caso de um gráfico de barras) ainda não é clara.

\subsubsection{Invertendo os sentidos dos registros: construindo tabelas a partir dos gráficos}

De acordo com Duval (2003), os sentidos de conversão não são homogêneos e o fato de treinarmos a conversão em um sentido (por exemplo, a construção de gráficos a partir de tabelas), não implica um treinamento automático do sentido oposto.

Além disso, o pesquisador afirma que, no ensino, geralmente, um sentido é priorizado. Buehring, Flores e Moretti (2005) constataram isso analisando as atividades referentes ao Tratamento da Informação nos livros didáticos do Ensino Fundamental.

\footnotetext{
[...] poucos foram os momentos, em todos os livros examinados, que além de transformar uma tabela em um gráfico, o aluno pudesse converter a representação gráfica para a tabela ou uma tabela ou gráfico, para um texto escrito na língua natural (BUEHRING; FLORES; MORETTI, 2005, p. 30).
}

Neste contexto e considerando como o processo de conversão enriquece o trabalho e possibilita ao aluno perceber que a Estatística é uma ferramenta de tratamento de dados, contando com diferentes formas de registro, pensamos em realizar uma atividade inversa das que realizamos até então. Ao invés de organizarmos gráficos a partir das tabelas de dados, construímos os gráficos de barras, colunas, setores e histogramas com os dados da escola toda e os distribuímos entre os grupos solicitando que, a partir deles, fossem organizadas as tabelas correspondentes e elaborado um pequeno texto a respeito dos dados representados.

Ficou evidente que, de fato, o processo reverso de mudança de registro não é trivial. Os alunos demonstraram-se bastante perdidos inicialmente, questionando "quais os dados que deveriam constar na tabela". Não reconheceram informações como títulos e complementações. Além disso, não estabeleceram de imediato a relação do tamanho das barras/colunas com o eixo de referência.

Dessa forma, iniciamos um processo de reflexão e discussão acerca dos procedimentos utilizados para a construção dos gráficos, de forma a estabelecer as devidas relações entre gráficos e tabelas. 
Constatamos que os alunos não estabelecem uma relação direta entre gráficos e tabelas e que a mudança de registro necessita ser trabalhada nas duas direções (tabela-gráfico e gráfico-tabela) para atingir mais ajustadas percepção e compreensão das informações representadas dessas duas maneiras. Além disso, constatamos muita dificuldade por parte dos alunos para calcular as frequências relativas, porcentagens, a partir dos dados representados nos gráficos, em razão de não terem clareza do que seria o $100 \%$.

Por outro lado, a riqueza da inversão dos registros foi evidenciada com as interpretações orais (falas dos alunos) acerca do que estava representado. Durante sua análise, foi possível perceber que, de fato, os alunos conseguiram fazer a leitura plena dos dados apresentados nos gráficos e transcritos para as tabelas. Neste contexto, ficou clara a pertinência de se considerarem os dois sentidos de conversão de registros para a tomada de consciência do objeto em discussão, no caso específico, de dados apresentados em gráficos e tabelas.

\subsection{Análise dos Dados}

Depois de coletados os dados e construídos os gráficos, passamos à formalização de sua análise, fundamentando-nos nas orientações do GAISE. As análises foram realizadas na sala de aula. Cada um dos grupos ficou responsável pela análise de uma questão - utilizando gráficos e/ou as tabelas, que foram impressos e entregues aos alunos.

\subsubsection{Análise dos Dados no Nível A}

No nível A, objetivamos o início da conscientização da distinção entre questões estatísticas e questões determinísticas, haja vista que as primeiras são variáveis e sujeitas ao acaso. Dessa forma, trabalhamos apenas com os dados da sala de aula. Portanto, as análises foram pautadas em exemplos específicos que visaram à percepção da variabilidade existente entre os indivíduos do grupo, por meio da comparação indivíduo com indivíduo, induzindo ao início da percepção da variabilidade entre grupos.

Solicitamos, então, que os alunos analisassem os dados da sala, elaborando uma frase que os representasse. As frases foram as seguintes: 
Tem um pouco mais de meninas do que meninos (G. 3).

Os alunos da $8^{a} B$ têm entre 14 e 15 anos, sendo que tem muito mais gente de 14 do que de 15 (G.5).

$73 \%$ tem computador (G. 6).

Quase todo mundo tem celular (G. 7).

Os alunos usam bastante computador na escola (G. 2).

O que mais faz no computador é usar MSN e Orkut (G. 3).

A maioria dos alunos fica de 1 a 2 horas no computador por dia (G. 4.).

O celular é mais usado pra fazer ligações, ouvir música e enviar torpedo (G. 1).

Em decorrência é possível afirmar, quando se comparam as análises: os alunos que ficaram responsáveis pelas análises das tabelas tiveram muito mais dificuldade que os que analisaram os gráficos, confirmando o entendimento de Flores e Moretti (2005), sobre a dificuldade de interpretação de uma tabela, principalmente de dupla entrada, que exige uma visão global das informações e uma análise simultânea das informações dispostas horizontal e verticalmente.

Além disso, pela construção das frases escritas, identifica-se que foi dada prioridade ao item que mais aparece, desconsiderando os demais, exceto quanto ao uso do celular que os alunos perguntaram se poderiam falar três coisas. Isso, ainda remete às atividades que até então foram desenvolvidas no decorrer da formação desses alunos, quando se priorizam as classes de maior frequência, desconsiderando os demais dados, dificultando uma análise global.

Recebidas as frases, escolhemos três alunos e questionamos se as informações se enquadravam com a característica deles. Muitas eram compatíveis, mas outras não. Perguntamos aos demais alunos por que as características da sala eram diferentes das características daquele grupo.

$$
\begin{aligned}
& \text { Porque cada um é cada um }\left(a_{41}\right) \text {. } \\
& \text { É diferente! }\left(a_{35}\right)
\end{aligned}
$$

As discussões giraram em torno disso. Cada um dos alunos apresentava características particulares e muito diferentes. Os alunos passaram a tomar outros grupos da sala realizando contraposições ao grupo que havíamos escolhido. As características eram diferentes, essa era a conclusão: de acordo com o grupo selecionado, encontrávamos características diferentes.

Chegamos ao objetivo da atividade. A situação didática foi concluída, de forma que pudemos institucionalizar o conhecimento adquirido. Assim, formalizamos a discussão realizada como os dados da própria sala de aula da seguinte madeira: Em uma análise estatística temos que considerar a variabilidade entre indivíduos, pois mesmo numa sala 


\section{de aula com um número de alunos relativamente pequeno a variabilidade das características é bastante grande.}

\subsubsection{Análise dos Dados no Nível B}

No nível $\mathrm{B}$, pretendemos uma sensibilização mais profunda quanto à distinção de questões estatísticas, no âmbito da variabilidade. Para tanto, fizemos com que os alunos comparassem os dados da sala com os dados obtidos com os alunos das outras duas $8^{\mathrm{a}} \mathrm{s}$ séries da escola, na direção de que identificassem e precisassem as características da amostra, bem como os erros inerentes de uma amostragem inadequada. Dessa forma, acreditamos que os alunos reconheceram que uma amostra pode ou não ser representativa de uma população mais ampla.

Solicitamos que cada grupo comparasse os gráficos e tabelas da $8^{\mathrm{a}}$ série $\mathrm{X}$ com os gráficos e tabelas das demais $8^{\mathrm{a}} \mathrm{s}$ séries, verificando se existia alguma relação. As respostas obtidas foram:

\footnotetext{
Nossa sala tem mais meninas e nas outras oitavas tem mais meninos (G. 3.)

Aqui só tem aluno de 14 e 15 anos e nas outras oitavas tem gente com 13, 16 e 17 (G. 5).

Nas outras $8{ }^{a}$ s $85 \%$ têm computador (G. 6).

Quase todo mundo tem celular em todas as oitavas (G. 7).

Na $8^{a} X$, o lugar onde mais usa computador é na escola e em segundo é em casa. Nas outras $8{ }^{a}$ S esses dois lugares empatam em primeiro (G. 2).

Todo mundo usa as mesmas coisas no computador, mas nas outras tem mais gente (G. 3).

Nas outras $8{ }^{a}$ s, também o que mais tem é de 1 a 2 horas no computador (G. 4).

Nas outras $8{ }^{a} \mathrm{~S} e ́$ diferente. Em primeiro é ligação, em segundo foto e em terceiro música (G. 1).
}

Nessas expressões, foi possível vislumbrar certa dificuldade para comparar os dados, principalmente, nos gráficos e nas tabelas que não apontavam porcentagem, porque os alunos tendem a considerar a frequência absoluta e não a relativa, como se observa na frase referente ao uso do computador. Organizamos, então, uma discussão a respeito da maneira adequada para comparar os dois grupos, tendo em vista que eles têm tamanhos diferentes. Necessitamos comparar as porcentagens das classes, tentando verificar a similaridade ou não. Isso é impossível se compararmos as frequências absolutas, já que o grupo maior, mesmo apresentando características semelhantes ao menor, apresentará números superiores e comprometerá a análise.

A partir dessa discussão e do recebimento das frases, lemos todas para a turma, levantando comentários a respeito. Perguntamos: considerando essas informações, a $8^{\mathrm{a}} \mathrm{X}$ é 
um grupo bom para representar as características dos alunos da $8^{\text {a }}$ série dessa escola? Os alunos disseram que não, porque tinha bastante coisa diferente, a começar pelo número de meninas e meninos.

Diante dessa constatação institucionalizamos a segunda constatação da investigação exploratória de dados: Além da variação dos indivíduos, numa análise estatística, temos de considerar a variação entre os grupos envolvidos, tendo em vista que os grupos envolvidos, além de apresentarem características variáveis em seus indivíduos, também são diferentes.

\subsubsection{Análise dos Dados no Nível C}

O nível C pressupõe que os alunos sejam capazes de fazer distinção entre questões estatísticas e determinísticas (ASA, 2005), de forma autônoma, procurando generalizações, bem como salienta a necessidade da seleção aleatória para amostragem. Nesse nível, pretende-se que os alunos sejam capazes de medir a variabilidade, quantificar e descrever o erro amostral. Além disso, prevê que os estudantes apliquem e analisem modelos de associação. Neste contexto, e, de acordo com os PCN para o Ensino Fundamental, acreditamos que essa habilidade vai além das orientações, devendo ser tratada mais adequadamente no ensino médio. Nosso trabalho se limitou à percepção da necessidade da amostragem aleatória de forma a reduzir o erro amostral, bem como da leitura e interpretação comparativa dos dados.

Solicitamos aos alunos que, de forma análoga como trabalharam com os dados da sala e das demais oitavas séries, fizessem uma análise comparando as características da $8^{\circ}$ $\mathrm{X}$ com as de todos os 524 alunos investigados na escola. Além disso, pedimos para que, se possível, as frases fossem mais completas, contemplando ao máximo as informações.

Os alunos tiveram muita dificuldade em romper com a visão pragmática de se olhar apenas uma característica e não conseguir perceber o todo. Foi necessária a intervenção do professor a fim de que percebessem algumas relações. Além disso, tentamos fazer com que levantassem questões e as respondessem, de acordo com princípio do GAISE para esse nível. Eles não o conseguiram. Necessitavam que "o professor" fizesse as perguntas para buscar as respostas.

As frases construídas foram as seguintes:

$\mathrm{Na} 8^{a} \mathrm{X}$ tem mais meninas e na escola inteira tem mais meninos (G. 3). 
A $8^{a} X$ não pode ser considerada como representação de toda a escola, porque na $8^{a}$ $X$ os alunos têm entre 14 e 15 anos. Já os alunos de toda a escola as idades variam muito (G. 5).

As porcentagens de quem tem computador são quase as mesmas na $8^{a}$ X e na escola (G. 6).

$88 \%$ dos alunos da $8^{a} X$ têm celular e $92 \%$ dos alunos da escola tem celular (G. 7). Todos usam o computador em $1^{\circ}$ lugar para MSN e Orkut e em segundo lugar para música. Só e diferente a partir do terceiro, que na nossa sala é pesquisa e na escola é vídeo (G. 2).

As características da $8^{a} X$ são totalmente diferentes da escola toda, por exemplo: $o$ total de alunos que ficam mais de 4 horas no computador na $8^{a} X$ é menor do que o total que fica de 1 a 2 horas e na escola inteira o total de pessoas que fica mais de 4 horas é muito maior do que de 1 a 2 horas (G. 3).

$\mathrm{Na} 8^{a}$ X e na escola o que mais os alunos fazem no celular é ligar. Mas em segundo e no terceiro lugar é diferente: na $8^{a} X$ é música e torpedo e na escola foto e música (G. 4).

Como esperávamos, os alunos não fizeram menção aos percentuais (frequências relativas) para justificar suas concepções, apoiando suas afirmações apenas nas informações das frequências absolutas. Explicamos novamente que, ao trabalharmos com conjuntos de tamanhos diferentes e, nesse caso, bem diferentes, não podemos utilizar as frequências absolutas para comparar os dados, já que podemos incorrer em erros. Os alunos pareceram entender.

Então era assim que a gente ia compreender que mesmo com tamanhos diferentes, as porcentagens dos dois grupos eram parecidas. Agora eu entendi como faz, professor $\left(a_{23}\right)$.

Finalmente, diante das afirmações por eles apresentadas, concluímos que a $8^{\mathrm{a}} \mathrm{B}$ não seria uma boa amostra para estudarmos todos os alunos da escola. Eles concordaram. Então, projetamos os gráficos de cada uma das séries para cada uma das variáveis trabalhadas, fazendo alguns apontamentos sobre as diferenças existentes entre cada um deles e perguntamos se haveria alguma maneira de tentarmos obter uma amostra representativa, considerando toda a variação existente entre os grupos.

A aluna $a_{12}$ sugeriu para dividir os alunos em grupos, que tivessem características semelhantes e retirar 1 de cada grupo. Perguntamos se essa alternativa daria certo, a partir de um exemplo. Vamos separar os alunos por idade e pegar um aluno de cada idade. Como será a distribuição de um gráfico de coluna construído a partir dessa amostra?

Todas as colunas teriam o mesmo tamanho $\left(a_{52}\right)$.

Apontamos para o gráfico de distribuição das idades dos alunos da escola e perguntamos: ele seria semelhante a este? Todos perceberam que não. Concluímos que essa alternativa contemplaria todas as características, mas não distribuídas como estão na escola. 
O aluno $a_{11}$ sugeriu que escolhêssemos o mesmo número de alunos de cada série e montássemos uma amostra. Iniciamos uma discussão analisando como esses alunos seriam selecionados, em dois momentos:

1. Consideremos os dados colhidos. Temos 92 alunos no $1^{\circ}$ ano do EM e 52 no $3^{\circ}$ ano de EM. Perguntamos: conseguiremos ser justos buscando contemplar as características dessas duas turmas, com tamanhos diferentes, se tomarmos um mesmo número de alunos em cada uma delas? Os alunos se lembraram da discussão realizada acerca das comparações e disseram que tinha que usar as porcentagens, ou seja, o número de alunos de cada grupo deve ser proporcional ao total de alunos de cada série.

2. Passamos à discussão de qual seria a melhor forma de se escolher esses alunos. Surpreendentemente, o aluno $a_{62}$, que não era tido como "bom aluno", mas participou das atividades propostas com empenho, disse que tinha que ser aleatório. Eu pedi para que ele me explicasse como seria. Ele disse que poderia ser por meio de sorteio. Formalizamos, portanto, a segunda questão: a escolha dos indivíduos de cada uma das séries deve ser feita de forma aleatória.

Fechada a atividade, formalizamos a última constatação de nossas análises, institucionalizando o conhecimento construído no decorrer do desenvolvimento da sequência didática ora descrita. Para tentar minimizar os erros amostrais, considerando a variabilidade entre indivíduos e a variabilidade entre grupos, deve-se utilizar o princípio de amostragem aleatória, devendo essa ser proporcional ao tamanho dos grupos envolvidos na investigação. 


\subsection{Apresentação dos dados}

Ao final das atividades, acreditamos na importância de apresentar os dados de maneira que todos os interessados pudessem ter acesso a eles. Assim, os alunos elaboraram uma apresentação utilizando o Microsoft Power Point, com as representações e análises realizadas e divulgaram no blog da escola, com o propósito de devolver os resultados da investigação para toda a população envolvida.

Os slides foram organizados a partir dos gráficos e tabelas construídos e das frases elaboradas nas análises (APÊNDICE F). A referida apresentação foi disponibilizada pela Professora N no blog da Escola A, ao qual todos os alunos, professores e a direção da escola têm acesso. A facilidade de acesso permitiu que todos os alunos que participaram da pesquisa recebessem o retorno com as informações da escola. A Coordenação e a Direção da Escola A valorizaram os resultados do trabalho, tendo em vista que, a partir das constatações quanto às relações dos alunos com as mídias digitais computador e celular, a escola se dispôs a pensar na integração dessas tecnologias ao processo de ensino e aprendizagem. Além disso, os resultados apontados pelo trabalho-a forte presença da tecnologia na vida dos alunos e a constatação de que a escola é uma via de acesso a tecnologia relevante para grande parte dos alunos- subsidiarão ações por parte da escola no sentido de atender às necessidades e anseios de seu alunado.

A apresentação utilizando o software ratifica a importância da tecnologia no processo educacional, como facilitadora das ações e propulsora de um paradigma educacional com mais efetiva participação do alunado. Além disso, a disponibilização dos resultados da pesquisa na web evidencia o potencial da tecnologia, como difusora de informações, encurtando distâncias e desconsiderando a variável tempo. Uma informação que demoraria algum tempo para retornar à comunidade participante da pesquisa e que, cada agente a seu modo, apresentava interesse nos resultados, foi disponibilizada para consulta de qualquer indivíduo, nas mais diversas localidades do mundo, em questão de dias, após o término das atividades.

Como consideração final das análises da investigação realizada, não podemos deixar de salientar a importância, evidenciada, da escola enquanto via de acesso dos alunos (em alguns casos, a única) aos meios tecnológicos e digitais, particularmente ao computador. Dessa forma, ainda que ratifiquemos nossas anteriores avaliações quanto ao reducionismo presente nos argumentos apresentados para a incorporação da tecnologia ao processo de ensino e aprendizagem, apenas como forma de atender a uma demanda de mercado, fica 
evidente o papel social da escola no mundo hodierno. Embora não se deva justificar a presença da tecnologia na escola sob esses argumentos, certamente a integração tecnológica como meio propulsor de um novo paradigma educacional representa força motivadora para a superação das desigualdades sociais, visando a possibilitar igualdade de oportunidade a todos os cidadãos brasileiros. 


\section{ANÁLISES FINAIS E CONSIDERAÇÕES}

No contexto da Engenharia Didática, a análise a posteriori refere-se ao conjunto de resultados extraídos da atividade desenvolvida "que contribui para a melhoria dos conhecimentos didáticos que se têm sobre as condições da transmissão do saber em jogo" (ALMOLOUD, 2007, p. 177).

Em virtude de a sequência didática desenvolvida no presente trabalho fundamentar-se na Teoria das Situações Didáticas de Brousseau, a análise pauta-se na estrutura do milieu, observando as diferentes posições e relações do (e entre o) aluno e o saber no decorrer das atividades, com o intuito de evidenciar as possibilidades e limitações das atividades propostas, delinear o papel do professor em cada uma das etapas e avaliar as contribuições das TIC para a compreensão de princípios e ideias estatísticas, bem como desenvolvimento da capacidade de leitura e interpretação de gráficos e tabelas.

A teoria das situações aponta a necessidade de o professor provocar no aluno comportamentos que ele próprio teria que adotar autonomamente, a fim de manifestar seu conhecimento. Parece um paradoxo. A única solução consiste em envolver um terceiro elemento, o milieu, para estimular que a resposta do aluno se refira exclusivamente às necessidades desse milieu (que o professor conhece bem), e não às do professor. A importância do papel do professor está, então, na organização de uma relação entre aluno e milieu, que, por um lado deixa uma razoável incerteza que deve ser reduzida pelos conhecimentos do sujeito e ,por outro, faz com que essa redução possa realmente ocorrer, isto é, com um grau de incerteza limitado, do ponto de vista do professor.

Daí, entende-se o papel do milieu, fundamental para a compreensão do funcionamento da Teoria das Situações Didáticas em Matemática.

\subsection{Aprendizagem por adaptação}

A primeira hipótese da Teoria das Situações Didáticas é a de que o aluno aprende por adaptação ao milieu, a partir das dificuldades, contradições e desequilíbrios. Para tanto, Brousseau (1996 apud POMMER, 2008) expõe como ideia básica, aproximar o trabalho do aluno do modo como é produzida a atividade científica, ou seja, o aluno se torna um pesquisador, testando conjecturas, formulando hipóteses, provando, construindo modelos, conceitos, teorias e socializando os resultados. Portanto, cabe ao professor proporcionar 
situações favoráveis, de modo que o aluno nessa ação efetiva sobre o saber transforme-o em conhecimento.

A sequência didática aqui tratada pautou-se na realização de uma investigação exploratória de dados, em que os alunos puderam experienciar uma investigação estatística, perpassando todas as etapas e dificuldades que envolvem semelhante conjunto de atividades.

Como pesquisador/professor, tivemos o cuidado de organizá-las de forma que o aluno tivesse condições de realizá-las com os conhecimentos que já possuía, mas que contemplasse a presença constante do milieu antagônico, proporcionando a transformação do saber em conhecimento a partir de suas ações, por meio de adaptações. Segundo Brousseau, “a resposta inicial que o aluno pensa frente à pergunta formulada não (deve ser) a que desejamos ensinar-lhe: se fosse necessário possuir o conhecimento a ser ensinado para poder responder, não se trataria de uma situação de aprendizagem" (BROUSSEAU apud POMMER, 2008, p. 4). Dessa maneira, o desenvolvimento das atividades proporcionou a mobilização dos conhecimentos já existentes, mas principalmente os conflitos e contradições que evidenciaram os erros e equívocos pensados para o milieu, os quais gestaram as necessidades de avanços/adaptações.

Os exemplos não faltam, como a organização da tabela de dupla entrada, em que, inicialmente, os alunos pensaram numa tabela simples. No entanto, por meio de provocações do professor/pesquisador, depararam-se com a situação de que a tabela não respondia quantos alunos, por exemplo, não possuíam computador, mas faziam uso dele. Essa dificuldade deu origem à reflexão acerca dos conhecimentos que possuíam sobre a estrutura de uma tabela, pensando em como resolver o problema. Depois de muita discussão, chegamos à estrutura da tabela de dupla entrada. A apropriação desse conhecimento foi evidenciada quando, em situações semelhantes, os alunos já perceberam que a tabela de dupla entrada resolveria seus problemas, como no caso da questão 3, que envolvia o celular.

Desde o delineamento do instrumento para a coleta de dados, prezamos pela participação constante dos alunos, evidenciando e justificando suas escolhas. Trata-se da articulação constante entre as dialéticas de ação, formulação e validação, cujos conhecimentos foram postos à prova, gerando discussões intra e entre os grupos.

Em consequência, fica evidente que o precípuo trabalho do professor é o de propor ao aluno uma situação de aprendizagem para que (este) elabore seus conhecimentos como resposta pessoal a uma pergunta e os faça funcionar ou os modifique como resposta às exigências do milieu e não a um desejo do professor (BROUSSEAU apud POMMER, 2008). 
As dificuldades constatadas nas análises preliminares foram evidenciadas a partir da etapa de organização dos dados. Foi possível perceber que os alunos não tinham clareza da estrutura de uma tabela simples, tampouco de uma tabela de dupla entrada. De fato, a concepção de que se trata de uma estrutura simples é apenas visual, na medida em que ela não apresenta uma linha gráfica que facilite sua leitura e interpretação (FLORES; MORETTI, 2005). No entanto, com o desenvolvimento das atividades foi possível perceber avanços por parte dos alunos de modo a evidenciar certa familiaridade com a estrutura tabelar e com as operações e retiradas de informações de (entre) suas linhas e colunas. Por se tratar de uma temática significativa, os alunos realizaram suas análises comparando os resultados obtidos com os conhecimentos que já possuíam sobre a temática. Tal processo facilitou o rompimento com a visão fragmentada da análise de dados, proporcionando leituras e interpretações globais e contextualizadas.

Além disso, os cálculos das porcentagens denunciaram que o conceito não havia sido apropriado pelos alunos, o que certamente comprometia e compromete o processo de leitura e interpretação de gráficos, assim como outras habilidades algébricas e aritméticas.

A passagem de a representação tabelar para os gráficos mobilizou as funções de tratamento, porque os alunos puderam perceber que um mesmo dado pode ser representado por meio de diferentes formas de registro. Além disso, a inversão de sentido no processo de conversão dinamizou substancialmente as estruturas subjacentes à compreensão dos indivíduos. Aqueles que ainda não haviam conseguido relacionar as duas formas de registro perceberam, de fato, a relação existente entre os dados representados na tabela e no gráfico. Constatamos, portanto, a função de objetivação dos registros, tendo em vista a explicitação oral da compreensão dos alunos.

A organização dos gráficos no software SuperLogo 3.0 proporcionou os avanços nos níveis dos milieux dos alunos, na medida em que, com os conhecimentos matemáticos prévios e os conceitos fundamentais para a linguagem LOGO, eles conseguiram construir as representações. No entanto, como não tinham se apropriado das relações existentes nos gráficos (particulamente, a relação entre os eixos numéricos e as barras e/ou colunas) o resultado apresentado na janela gráfica não condizia com o esperado. Era necessário compreender o porquê dessa inconsistência. A interação intra e entre grupos favoreceu sobremaneira os processos de depuração dos erros e de correção dos comandos, de forma que, sem a intervenção do professor/pesquisador, os alunos conseguiram compreender o erro, analisá-lo, depurá-lo e estabelecer as devidas relações. Essa atividade facilitou o processo posterior de leitura, interpretação e análise dos dados, confirmando a hipótese de que 
A resolução de problemas permanece recomendada para o trabalho com Estocástica, agora acentuada pelas características das aulas investigativas. Ao se estabelecer uma questão de investigação, é preciso optar por estratégias que levem os alunos a respondê-la. É necessário organizar, representar e analisar os dados a partir do problema. Inseridos nesse processo de aprendizagem, os estudantes têm apresentado maiores possibilidades de desenvolvimento do pensamento crítico (LOPES, 2008a, p. 69).

A afirmação de que este tipo de atividade favorece o desenvolvimento do raciocínio crítico foi evidenciada no decorrer da sequência, pois, nas análises, os alunos puderam perceber a variabilidade existente num problema estatístico, de modo a compreender o princípio de amostragem aleatória. Além disso, em vários momentos pudemos perceber uma análise global dos dados, rompendo com a visão pontual, presente na maioria das atividades de leitura e interpretação de gráficos.

Como o aluno indica que não faz uso do computador na questão 3 e 6 e enumera itens na questão 5? $\left(a_{52}\right)$

Com a criação de situações nas quais os alunos foram levados a "pensar sobre" constrói-se conhecimento fundamentado e significativo, de modo a facilitar a tomada de consciência por parte do aprendiz. A partir do momento em que o aluno compreendeu a existência de uma variabilidade entre os indivíduos de um determinado grupo, ele criou condições para perceber que, tomando grupos diferentes, as características de cada um deles também poderiam variar (variabilidade entre grupos). Essas constatações só foram internalizadas porque decorreram de uma experiência real que os colocou em uma situação de dificuldade na explicitação de argumentos para justificar informações contraditórias. Após a compreensão das duas naturezas iniciais da variabilidade, foi possível desenvolver as idéias que sustentam o princípio de amostragem aleatória.

De forma semelhante, quando pensamos no desenvolvimento do raciocínio proporcional, as atividades levaram o aluno a estabelecer as relações de proporcionalidade entre os dados reais e os "passos de tartaruga", de forma a considerar tanto a (in)variância quanto a covariância dos dados reais. $\mathrm{O}$ trabalho com dados reais e dinâmicos possibilitou o confronto constante entre o resultado gráfico esperado e aquele apresentado pela tartaruga após a execução do comando. Essa dinamicidade favoreceu o desenvolvimento de duas habilidades/relações simultaneamente: quando o aluno verificava a não correspondência entre o resultado esperado e a construção apresentada pela tartaruga, ele retomava as proporções estabelecidas para verificar se os cálculos estavam corretos ou havia algum equívoco no comando indicado, depurando seu raciocínio. Por outro lado, para constatar que a construção gráfica não representava de maneira fidedigna os dados organizados nas tabelas, era 
necessário compreender as relações existentes entre eixos, barras e colunas. Portanto, o trabalho com o SuperLogo 3.0 possibilitou adaptações sucessivas e inter-conceituais, de maneira a romper com a visão pontual e possibilitar interlocução entre conceitos e estruturas algébricas, aritméticas e geométricas, tanto no contexto matemático, quanto no estatístico.

Finalmente, a institucionalização da atividade permitiu corrigir distorções, estimulando que os alunos se apropriassem dos conceitos matemáticos e estatísticos envolvidos e compreendessem a organização e as relações existentes nos gráficos de barras, colunas, setores, histogramas e tabelas simples e de dupla entrada. Apesar de defendermos o construcionismo, temos plena consciência de que o processo de ensino e aprendizagem não pode pautar-se no espontaneísmo, um equívoco muito frequente na compreensão dos princípios e fundamentos que sustentam esse paradigma. Confirma-se novamente o papel singular do professor, enquanto mediador e interventor do conhecimento, porque distorções podem permanecer após as atividades e a institucionalização adequada do conhecimento desempenha fundamental importância para garantia da qualidade do saber construído/ensinado.

\subsection{As intenções didáticas do milieu}

Brousseau enfatiza que as situações de ensino devem ser criadas pelo professor, de modo a aproximar o aluno do saber do qual ele deve se apropriar. Para isso, cabe ao docente fazer um duplo papel cíclico. Primeiro, procurar situações nas quais os alunos possam dar sentido ao conhecimento, através da contextualização e personalização do saber, num movimento de vivenciar o conhecimento pelo aluno. Segundo, ajudar seus alunos no sentido inverso, ou seja, descontextualizando e despersonalizando os conhecimentos, como fazem os matemáticos, de modo a tornar as produções dos alunos fatos universais e reutilizáveis.

No contexto da investigação exploratória de dados desenvolvida neste trabalho, trata-se de contextualizá-la de forma a atribuir sentido aos conceitos e estruturas envolvidos, para, ao final, institucionalizar o conhecimento de forma que ele possa ser aplicado em outras situações do cotidiano, tendo em vista que não é possível garantir que obter experiência estatística a partir de um projeto de análise de dados em sala de aula possa gerar uma Literacia Estatística num nível adequado (GAL, 2002). 
As intenções didáticas não foram explicitadas aos alunos, visto que todo o desenvolvimento da sequência de atividades funcionou como uma situação adidática, envolvendo algumas situações didáticas implícitas. Esse caráter adidático contribuiu para o envolvimento dos alunos nas atividades, já que, em muitos momentos, eles não percebiam que estavam aprendendo e/ou estudando Matemática e Estatística.

Todas as aulas deveriam ser assim. Nem parece que estamos na aula de Matemática $\left(a_{61}\right)$.

Vamos continuar organizando as tabelas, professor. Dá trabalho, mas é legal ( $\left.a_{21}\right)$.

Além disso, as interações intra e entre os grupos facilitou a tomada de consciência e o desenvolvimento das intenções didáticas implícitas nas atividades. Basicamente, as intenções eram que percebessem:

(i) Quando existe a necessidade de realização de uma investigação estatística. Essa percepção ocorreu no momento em que eles se depararam com as questões propostas pelo professor/pesquisador, envolvendo as semelhanças e diferenças existentes entre a $8^{\circ}$ série $\mathrm{X}$ e os alunos das demais $8^{\mathrm{a}} \mathrm{s}$ séries, ou os outros alunos da escola.

(ii) As etapas que envolvem uma investigação exploratória de dados. Os alunos puderam vivenciar uma investigação estatística e perceber todas as etapas e dificuldades que a envolve. Constataram que os resultados dependem muito da qualidade das questões elaboradas para a coleta de dados.

\footnotetext{
Acho que eles [os alunos da quinta série] não entenderam a questão. Se estou pedindo para numerar, porque marcou um x. Tivemos que explicar pra eles e pedir pra refazer. Será que não dava pra entender? Talvez pudéssemos ter melhorado o questionário, né professor $\left(a_{12}\right)$.
}

(iii) Os conceitos matemáticos envolvidos numa representação gráfica.

Muitos dos conceitos matemáticos necessários não estavam formados, conforme evidenciado nas análises preliminares. O trabalho contextualizado facilitou a compreensão de diversos deles, como os de probabilidade e conjuntos. Além disso, o trabalho com o SuperLogo 3.0 envolveu o raciocínio proporcional, facilitando a compreensão das ideias de razão, proporção e escala, além de tratar dos conceitos geométricos de retângulo, círculo e ângulo.

(iv) O princípio de variabilidade e de amostragem aleatória. $\mathrm{O}$ trabalho de comparação entre os dados da $8^{\mathrm{a}}$ série $\mathrm{X}$ e dos demais alunos da Escola A proporcionou a compreensão de que existe variabilidade entre os indivíduos do grupo e entre grupos. Esse entendimento os levou a compreender/construir o princípio de amostragem aleatória, sua relevância e aplicabilidade. Cabe salientar que o objetivo do trabalho não focava o cálculo das medidas de variabilidade e do nível de significância dessa variação. A partir das concepções 
de Batanero (2002), objetivamos contemplar o tratamento das ideias que sustentam a Educação Estatística, entendendo que, com a compreensão dos fundamentos que envolvem essa ciência, os alunos podem criar condições conceituais e procedimentais para lidar com os cálculos estatísticos no EM. Caso contrário, ainda que consigam lidar com os algoritmos para cálculos de medidas de tendência central, variação, assimetria e significância, por exemplo, esses resultados não trarão nenhuma informação significativa para suas vidas, porque a compreensão de que o contexto atribui sentido às informações estatísticas não foi internalizada/trabalhada.

(v) Raciocínio crítico diante dos dados e desenvolvimento da literacia. Em se tratando de situações adidáticas, os alunos tiveram liberdade de explicitar suas ideias e justificar suas opções. Isso facilitou a discussão e comparação dos raciocínios, no processo de validação dos saberes construídos através da necessidade e validação deles, sem intervenção do professor. O uso do Excel e do SuperLogo 3.0 contribuiu para isso, na medida em que o computador facilitou o processo de construção das representações (ainda que na linguagem LOGO os alunos tenham enfrentado alguma dificuldade inicial), assim como estimulou discussões ricas quanto ao raciocínio envolvido. Lopes e Carvalho (2009) afirmam que

Os estudantes, durante a educação básica, precisam não somente tornar-se conscientes de seu pensamento e raciocínio, mas também discutir e comparar diferentes soluções para problemas estatísticos e suas respectivas interpretações, deduções e explicações. Devem ainda ter a oportunidade de usar a tecnologia para explorar e lidar com dados, para ser possível dar maior ênfase ao raciocínio do que aos cálculos e construções (p. 90).

Neste contexto, as intenções didáticas estavam presentes em todas as atividades da sequência e foram evidenciadas no decorrer da investigação dos dados, levando os alunos a compreenderem os princípios e conceitos matemáticos e estatísticos envolvidos no processo de resolução de problemas estatísticos. 


\subsection{Os saberes engajados na sequência didática}

As análises preliminares evidenciaram que os alunos apresentavam muitas dificuldades quanto aos conhecimentos e habilidades envolvidos na leitura e interpretação de gráficos e tabelas.

Dentre os conceitos matemáticos, constatamos deficiências quanto aos números decimais e suas representações fracionárias e percentuais, conjuntos numéricos, porcentagem, proporção e ângulos. O desenvolvimento das atividades num contexto significativo para os alunos (a relação dos alunos da escola com o computador e o celular) criou um significado preciso para a ideia de porcentagem e a compreensão das diversas possibilidades de registro para sua representação. Apesar de se tratar de um conceito fundamental para todas as áreas do conhecimento, ficou evidente a insuficiência de conhecimento quanto à significância da porcentagem. Partindo da compreensão de que o conceito representa uma parte de 100 , com o trabalho de cálculo de percentuais do grupo, os alunos constataram que, na verdade, o 100 indica uma totalidade (cem por cento), de que a porcentagem é uma parte.

Além disso, a atividade proposta, por envolver a comparação entre diversos grupos (as séries) e a compreensão de que integram um grupo maior (os alunos da Escola A), portanto, são subgrupos, possibilitou o tratamento dos conceitos de conjunto e subconjuntos, de modo a trabalhar as relações de pertinência existente, entre essas estruturas.

A linguagem LOGO possibilitou o trabalho com os conceitos geométricos de retângulo, círculo, setor circular e ângulo. Embora fundamentais, tais conceitos se mostraram deficitários em nossa investigação diagnóstica e nas avaliações, em geral. Além disso, a integração de conceitos geométricos no Tratamento da Informação corrobora a idéia de desfragmentação do conhecimento matemático, visando a estabelecer as relações entre as diversas áreas que a integram, o que muitas vezes fica comprometido no processo de ensino e aprendizagem, dando a entender que a Matemática pode ser tratada de forma particionada.

A construção dos gráficos no SuperLogo 3.0 mobilizou o desenvolvimento da ideia de proporção, envolvendo os conceitos de razão e escala. Ratificamos aqui a constatação que apontamos na seção anterior: o desenvolvimento simultâneo da compreensão das relações existentes entre os eixos e as demais partes que integram uma estrutura gráfica e a compreensão/desenvolvimento do raciocínio proporcional. Este certamente representa um 
diferencial da construção gráfica por meio da linguagem LOGO, que não pode ser contemplado numa construção gráfica utilizando outros meios, como o lápis e papel.

Em termos estruturais, percebemos que as tabelas de dupla entrada, apesar de pareceram registros simples, apontam significativa dificuldade na sua leitura e interpretação, porque suscitam uma leitura global, a partir da articulação das informações apresentadas horizontal (linhas) e verticalmente (colunas). No entanto, a significância dos dados facilitou a compreensão desse tipo de estrutura.

As dificuldades dos alunos em interpretar e relacionar as informações a partir de gráficos e tabelas, retirando conclusões, foram se atenuando à medida que as atividades ocorriam e apontavam interpretações ricas a partir da leitura dos gráficos e tabelas.

Nesse contexto, destaca-se a compreensão da variabilidade presente no processo estatístico, de forma a estabelecer a diferença fundamental da Educação Estatística para a Matemática. Apesar de não contemplar os cálculos para mensuração dessa variabilidade, acreditamos que o desenvolvimento das idéias que sustentam o conceito possa ser suficiente para o nível de ensino pesquisado, estimulando o desenvolvimento de uma Literacia Estatística de qualidade e, ao mesmo tempo, mobilizando a construção da competência estatística no EM.

Finalmente, consideramos que a sequência didática contemplou as três dimensões das intenções didáticas. Em termos conceituais, diversos foram os saberes matemáticos e estatísticos mobilizados no decorrer das atividades, conforme já destacado anteriormente. As etapas que compuseram a sequência proporcionaram a experiência de uma investigação estatística real, de modo a desenvolver as habilidades e procedimentos inerentes à Estatística. Por fim, considerando que tivemos por objetivo trabalhar as diversas naturezas da variabilidade visando ao desenvolvimento da Literacia Estatística, as atividades estimularam o desenvolvimento do raciocínio crítico, a fim de romper com a (in)compreensão enviesada das informações estatísticas presentes no dia-a-dia. Portanto, contemplou questões atitudinais dos alunos, com o desenvolvimento de uma postura crítica, quando deparados com questões que envolvem variabilidade e incerteza. 


\subsection{Respondendo às Questões de Investigação}

Concluindo a análise da sequência didática desenvolvida, retomamos nossas questões de investigação, no sentido de verificar se conseguimos respondê-las e apresentar algumas considerações as quais julgamos relevantes.

Quais características podem contribuir para que uma Investigação Exploratória de Dados possa, de fato, caracterizar uma situação de resolução de problema, de forma a possibilitar que os alunos atribuam sentido à Educação Estatística por meio da experiência de um processo de investigação?

De acordo com os resultados das atividades da sequência didática, é possível afirmar que, conforme apontam Lopes (2008, 2009) e o GAISE (ASA, 2005), as situações problema em Estatística devem ter origem no contexto dos alunos, de modo que o processo de investigação ganhe sentido em meio à resolução de uma situação problematizada por eles próprios. Essa característica facilita a tomada de consciência das etapas (e características de cada etapa) que envolve uma investigação estatística. Além disso, traz contribuições para o desenvolvimento das competências apontadas pela PCSP.

Considerando a Estatística uma nova forma de linguagem e a Literacia Estatística como o processo de alfabetização, a sequência proporcionou a mobilização dos três eixos norteadores da ação educacional.

No eixo expressão/compreensão, à medida em que os alunos se envolveram nas etapas da investigação, desencadeou-se a familiaridade com conceitos e estruturas matemáticos e estatísticos, simultaneamente à compreensão, o que se confirmou no momento de organização, apresentação e interpretação dos dados, quando necessitaram utilizá-los para expressar suas idéias.

Quanto ao eixo argumentação/decisão, ao proporcionar um milieu antangônico, quando, constantemente, os alunos se depararam com situações de conflito, eles necessitaram criar argumentos que justificassem suas opções e ações.

Finalmente, o fato de as atividades partirem de uma situação problematizada pelos alunos e ser finalizada com a institucionalização do conhecimento pelo professor/pesquisador, utilizando a situação vivenciada para atribuir sentido aos conceitos em questão, mas tendo a preocupação em descontextualizá-los, de modo que o conceito não fosse confundido com o contexto de aplicação, acionou as habilidades de 
contextualização/abstração. O próprio ato de trabalhar os dados por meio das conversões de registro corroborou para o desenvolvimento dessa competência.

Quanto aos níveis de letramento estatístico proposto por Shamos (1995 apud Gal, 2002), constatamos que, inicialmente, os alunos encontravam-se no nível cultural, visto demonstrarem dificuldade quanto à leitura e interpretação de informações estatísticas, em razão de não terem se apropriado de termos básicos utilizados no cotidiano. Ao final, após a construção dos gráficos e com as análises e interpretações realizadas, acreditamos que eles tenham alcançado o nível funcional, tendo em vista que já utilizaram conceitos e linguagem estatística de forma adequada, bem como foram capazes de construir os gráficos e tabelas para representar seus dados demonstrando certa familiaridade com informações estatísticas. Quanto ao nível científico, pela própria maturidade cognitiva dos alunos da $8^{\mathrm{a}}$ série $\mathrm{X}$, julgamos difícil atingi-lo de forma plena. No entanto, como ficou evidente a compreensão quanto ao princípio, fundamento e relevância da amostragem aleatória para uma investigação, ela sinaliza avanços no sentido de lidar com a variabilidade onipresente no processo estatístico.

Dessa forma, acreditamos que a compreensão dessas idéias possibilita que os alunos atinjam o nível no EM, tendo em vista que nessa etapa está previsto o trabalho com cálculos de medidas de tendência central, variabilidade e significância.

Quanto às tabelas, não podemos fazer a mesma afirmação. Apesar do trabalho realizado, demonstraram-se dificuldades para comparar tendências e retirar informações não explícitas no registro. Em consequência, apesar de avanços perceptíveis no sentido de se realizar uma interpretação global das tabelas (um avanço cognitivo segundo Duval), a maioria dos alunos ainda permanece no nível elementar apontado por Wainer (1995 apud RIBEIRO, 2007), tendo em vista que não foi possível identificar leituras e interpretações envolvendo interpolações e descobertas de relações existentes implicitamente. Essa capacidade de compreensão ampla da estrutura tabelar, embora o enriquecimento seja perceptível, não foi desenvolvida plenamente, necessitando de um trabalho mais cuidadoso que trate especificamente dessa temática.

Quanto aos pressupostos teóricos, a sequência enfocou as quatro funções que as representações semióticas contemplam, de acordo com Duval. Sua mobilização funcionou como um fator de fundamental importância para a compreensão das idéias e estruturas estatísticas. A Comunicação é fundamental quando pensamos em Educação Estatística, haja vista que todo o processo está pautado na elaboração de representações e leituras passíveis de compreensão por parte de qualquer indivíduo. O Tratamento possibilitou a compreensão 
plena das relações existentes entre os diversos tipos de registro (por exemplo, entre a linguagem escrita e uma tabela, uma tabela e um gráfico, e vice-versa), de forma a retirar as informações invariantes das representações não confundindo o conceito com algum tipo de registro. A Objetivação foi favorecida pelo uso dos softwares Excel e SuperLogo 3.0, porque a construção de tabelas utilizando o aplicativo de planilhas eletrônicas evidenciou as relações existentes entre as linhas e colunas, motivando a compreensão desse tipo de estrutura (particularmente no concernente à porcentagem). A linguagem LOGO exigiu a explicitação do raciocínio utilizado na construção gráfica. Dessa forma, por meio do erro, os alunos puderam depurar seus equívocos e compreender idéias e conceitos até então não apropriados. Seus discursos e os caminhos percorridos para a correção das inconsistências encontradas evidenciam a compreensão daquilo que até então apresentava deficiência. Finalmente, a necessidade de se buscar constantemente as informações organizadas nos diversos tipos de registro evidenciou a mobilização da função de Identificação, explicitando o constante trabalho cognitivo que possibilita a recuperação da memória.

Sustentados pela Teoria das Situações Didática de Brousseau, resgatamos os quatro tipos de interações fundamentais para analisar o processo de aprendizagem tratado na sequência didática. $O$ fato de a investigação partir de uma situação-problema retirada do contexto dos alunos facilitou a dialética de ação, de modo a possibilitar a retroações sobre o milieu e manipulação das estruturas e saberes envolvidos num processo de investigação estatística. O trabalho em grupo e as provocações do professor/pesquisador estimularam a dialética de formulação, à medida em que os alunos constantemente necessitavam explicitar seus raciocínios por meio de manifestações verbais, de modo a possibilitar a troca de experiências, a contraposição de idéias e a avaliação das formulações elaboradas. A partir dessas discussões, foi possível validar o modelo apresentado pelos alunos, sustentado na teoria apresentada que, embora fundamente a validação ou refutação dos modelos propostas, também funciona como milieu antagônico, porque subsidia as contestações dos demais colegas e as provocações do professor/pesquisador. Por fim, cabe destacar a importância da institucionalização do conhecimento construído oficializando esse saber. A explicitação e formalização dos conceitos possibilitam a descontextualização do novo saber, tornando possível sua aplicação/contextualização em outros contextos, de modo a despersonificar o conhecimento construído, tornando-o utilizável em outras situações.

Dessa forma, acreditamos que uma atividade que contribua para o desenvolvimento da Literacia Estatística necessita partir de uma situação problematizada pelos alunos, envolver a estrutura do milieu antagônico constantemente e possibilitar que a 
experiência do aluno se aproxime da realidade de uma investigação científica, com os conflitos e complexidade próprios dela. Além disso, são funcionais ações que visem à descontextualizar o conhecimento construído de modo a torná-lo aplicável a outros contextos, impossibilitando a confusão do saber com o tipo de registro utilizado ou a situação na qual ele foi construído. Por fim, temos que destacar a importância da institucionalização do conhecimento para sanar possíveis equívocos e vieses decorrentes da (in)compreensão dos alunos. Acreditamos que a sequência desenvolvida confirmou nossas constatações.

Como a integração das Tecnologias de Informação e Comunicação (TIC) nessa Investigação Exploratória de Dados pode trazer contribuições para o processo estatístico, particularmente no que concerne à atribuição de significado às informações representadas por meio de gráficos e tabelas?

Partindo da elaboração do questionário de coleta de dados (Word), passando pela organização dos dados (Excel) e finalizando com a apresentação deles (SuperLogo 3.0 e Powerpoint), as TIC estiveram presentes como forma de facilitar os processos organizacionais e construtivos, bem como de possibilitar a focalização dos processos e não apenas dos resultados, do raciocínio e não apenas na estruturas finais, coadunando com as orientações de Lopes e Coutinho (2009).

Particularmente quanto aos softwares utilizados para a organização dos dados, cabem algumas considerações.

O Excel, apesar de ser um software comercial não direcionado, portanto, à ação educacional, facilitou o processo de construção das tabelas, na medida em que apresenta estrutura de planilha eletrônica. Assim, facilita tanto a estruturação das tabelas, quanto os cálculos de linhas totalizadoras e frequências relativas. Neste contexto, de acordo com as atividades elaboradas pelo professor, apesar de apresentar características instrucionistas, o software pode ser utilizado em atividades de construção de conhecimento. Por exemplo, os cálculos de porcentagens na planilha eletrônica podem proporcionar a reflexão quanto ao conceito de porcentagem. Quando os alunos efetuaram cálculos equivocados para as porcentagens, a totalização das frequências relativas não contabilizou 100\%. Essa inconsistência desencadeou o processo de reflexão quanto à ação desenvolvida no intuito de depurar possíveis erros conceituais. A interatividade da planilha facilitou a visualização das alterações, bem como a compreensão da relação parte-todo, de modo que os alunos perceberam que o erro estava na população total considerada (o total de indivíduos e não cem, como pensado inicialmente em virtude do equívoco na compreensão do conceito de 
porcentagem). Em decorrência, o Excel proporcionou a espiral da aprendizagem, a partir de uma situação criada pelo professor/pesquisador.

Entretanto, cabe um destaque quanto à forma de utilização desse software no contexto escolar, haja vista que todos os alunos envolvidos na pesquisa informaram ter utilizado o Excel em atividades na própria Escola A, sem demonstrar familiaridade com a estrutura de funções, que possibilita efetuar cálculos na própria planilha.

Por outro lado, destacamos que a construção de gráficos nesse aplicativo ocorre de modo automatizado, sem que haja explicitação das relações existentes entre os dados organizados (tabelas) e a representação gráfica correspondente. Além disso, os modelos para os gráficos são previamente estabelecidos, limitando as possibilidades para a representação de dados. A construção gráfica no Excel, portanto, não favorece a espiral de aprendizagem, em razão do processo automatizado e pouco adaptável, que não possibilita a explicitação do raciocínio do aluno, tampouco a clareza quanto à relação existente entre a ação do aprendiz e a execução da máquina. Essa limitação dificulta a reflexão por parte do aluno quanto aos possíveis erros conceituais e procedimentais presentes em seu raciocínio. Além disso, a intervenção do professor também fica prejudicada, já que ele não conta com os registros das ações (raciocínio) do aluno para delinear suas provocações e mediações.

Apesar de a linguagem de programação utilizada no SuperLogo 3.0 apresentarse inicialmente como um dificultador, após a familiarização dos alunos com ela, a construção de gráficos, por meio dos comandos no LOGO, funcionou como um impulsionador da atribuição de significado aos gráficos de colunas, barras, setores e histograma. Esse sucesso deveu-se ao fato de que, ao ensinar a tartaruga, foi necessário que o aluno raciocinasse sobre as relações e conceitos subjacentes às estruturas gráficas, de modo a indicar o comando correto. $\mathrm{O}$ erro, na verdade, foi tomado como fator de aprendizagem, na medida em que foi o desencadeador da espiral da aprendizagem (VALENTE, 2002). O aluno, diante de inconsistência entre a ação da tartaruga e a esperada ao indicar o comando, autonomamente refletia e depurava o erro, às vezes com a interação com outros colegas do grupo e dos demais grupos.

Os exemplos, a seguir, explicitam a presença da espiral da aprendizagem no desenvolvimento das atividades da sequência didática:

(i) Não compreensão da estrutura que compõe um eixo gráfico: principalmente no início das atividades, alguns alunos praticamente desconheciam a estrutura gráfica e as características que a compõem, como amplitude e escala. Isso foi evidenciado no momento em que 
construíram o primeiro eixo, quando alguns desconsideraram até a relação de que a escala a ser utilizada deveria ser um divisor da amplitude total do eixo, originando eixos fora de escala (Figura 14). Os resultados causaram estranheza aos alunos, que argumentaram:

O programa está com problema $\left(a_{36}\right)$.

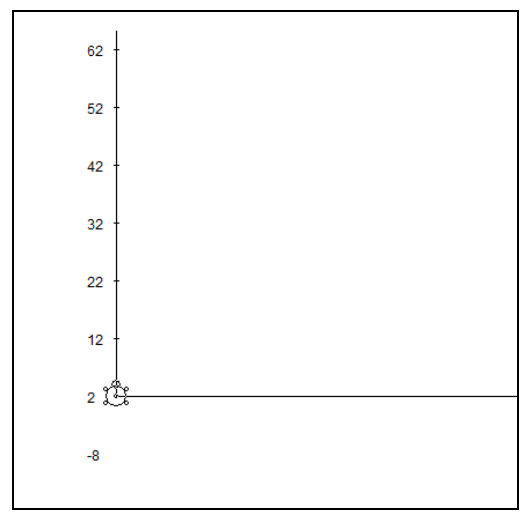

Figura 14: Eixo do gráfico de colunas com erro na escala

Contudo, a partir do raciocínio sobre o comando indicado (por exemplo, eixocoluna 623001050 ) e da troca de informações com os demais colegas intra e entre grupos e com o professor/pesquisador iniciaram o processo de depuração:

Mas 300 não dá pra dividir por 62. Tem que dar, né? $\left(a_{36}\right)$

O grupo resolveu utilizar outro valor, indicando o comando eixocoluna 5020010 50, originando um erro conforme mostrado na Figura 15.

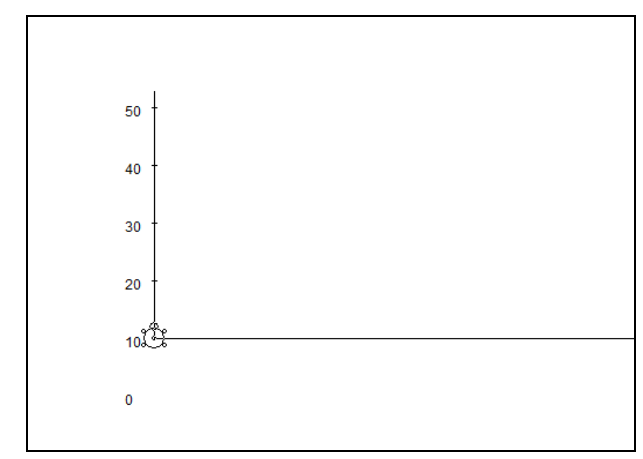

Figura 15: Eixos do gráfico de colunas com erro na proporção estabelecida entre os dados reais e os passos de tartaruga 
Nova depuração foi necessária, de modo a identificar o erro, pois naquele momento a escala era um divisor da amplitude, tanto real quanto em passos de tartaruga. Perguntando a outro grupo que havia construído o eixo corretamente, descobriram o erro.

Tem que ser o mesmo número que multiplica pra chegar nos passos de tartaruga. Tipo, se você está multiplicando o 50 por 4 pra chegar nos 200 passos de tartaruga, você tem que multiplicar o 10 por 4 também. Daí vai dar 40 e não 50 ? $\left(a_{52}\right)$

Dessa forma, conseguiram entender a relação de proporcionalidade existente entre a amplitude total e a escala para os intervalos, bem como entre as medidas reais (amplitude e escala) e em passos de tartaruga. No entanto, mais uma compreensão era necessária.

Como eu sei qual o valor que vou colocar no eixo? $\left(a_{36}\right)$

Essa questão evidenciou que os alunos não compreendiam que a amplitude total estava relacionada com o maior valor presente nas distribuições de frequência. Diante do questionamento quanto aos dados que seriam representados nos gráficos e da comparação com as construções dos demais grupos, foi possível perceber essa relação.

Se eu tenho um grupo com 62, que é o maior, esse número é que eu vou considerar, né? Mas como tem que dá pra dividir eu vou aproximar pra mais ( $\left.a_{36}\right)$

Dessa forma, todas as dificuldades quanto às informações contempladas num eixo de gráficos de colunas foram tratadas na construção do eixo, de modo a facilitar, posteriormente, a atribuição de sentido às barras. A estrutura do SuperLogo 3.0 possibilitou a espiral da aprendizagem, haja vista que, por meio de ações e reflexões, o aluno foi depurando seu conhecimento, compreendendo e construindo as relações necessárias para a construção correta do eixo, conforme apresentado na Figura 16. 


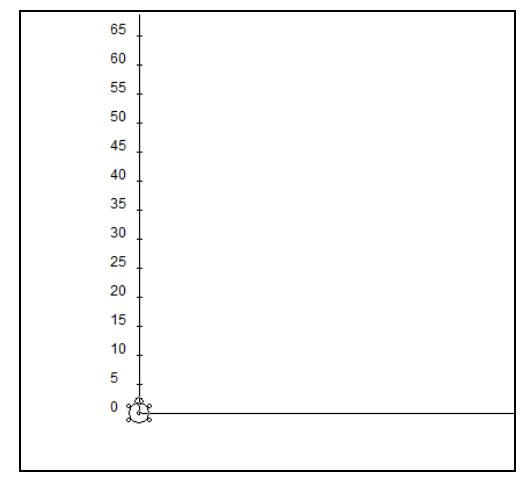

Figura 16: Eixo correto do gráfico de colunas construído após as depurações

(ii) Desconhecimento/esquecimento quanto à relação dos eixos numéricos com as demais partes dos gráficos e o desenvolvimento do raciocínio proporcional: trata-se novamente do tratamento simultâneo de duas habilidades fundamentais para a Literacia Estatística: a relação existente entre eixos e barras/colunas e o desenvolvimento do raciocínio proporcional. Isso foi evidenciado, por exemplo, quando o G.2, ao estabelecer uma razão de 5/1 entre os passos de tartaruga e os valores reais, esqueceu-se dessa proporção ao indicar 62 passos de tartaruga, com o objetivo de representar os 62 alunos que utilizavam computador em casa (Figura 17).

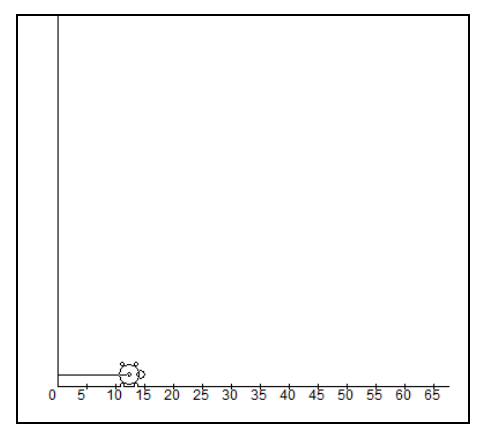

Figura 17: Erro do G.2 decorrente do "esquecimento" da proporção estabelecida

Por esperar um traço maior que o apresentado pela tartaruga, os alunos iniciaram o processo de reflexão quanto ao comando indicado e a ação executada no SuperLogo 3.0. Para tanto, é necessário compreender a relação existente entre o eixo numérico e a barra, compreendendo a relação fundamental para a leitura de um gráfico deste tipo. Diante 
dessa compreensão, é que foi possível detectar o equívoco ocorrido de modo a perceber e "desconsideração" da proporção estabelecida inicialmente. Depurado o erro ocorrido, os alunos foram capazes de corrigir o equívoco e indicar os 310 passos de tartaruga que representavam os 62 alunos, de acordo com a razão estabelecida (Figura 18).

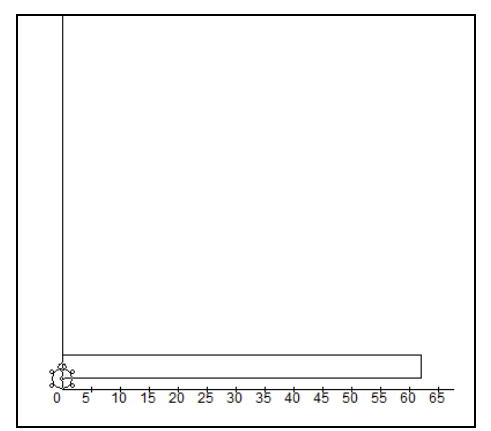

Figura 18: Barra construída corretamente de acordo com a proporção estabelecida

Além disso, a partir do milieu criado, o professor pôde atuar como mediador no processo de construção de conhecimento dos alunos. Os registros dos procedimentos por eles utilizados para a construção dos gráficos e os comandos empregados evidenciaram a compreensão/apropriação dos conceitos implícitos nas estruturas gráficas.

Em se tratando de estruturas e conceitos subjacentes à construção de gráficos, ficou evidente que as dificuldades que os alunos apresentam quanto à leitura e interpretação de gráficos estão relacionadas àquelas que envolvem outros conceitos matemáticos necessários para o desenvolvimento dessa habilidade. A porcentagem e a proporcionalidade são exemplos de quanto a Álgebra e a Aritmética estão relacionadas com a Estatística. Dessa maneira, quando se constroem gráficos por meio da utilização dos conceitos matemáticos implícitos na representação gráfica, torna-se possível o desenvolvimento do papel cíclico necessário a uma situação didática: contextualizar os conceitos matemáticos por meio de aplicações práticas, em nosso caso, na construção de gráficos. E, no sentido inverso, é possível despersonalizar os conhecimentos construídos pelos alunos, de modo a tornar suas produções fatos universais e reutilizáveis/aplicáveis em outros contextos. Essa característica é o que evidencia o grande diferencial do SuperLogo 3.0 na construção de gráficos, quando o comparamos a outros softwares (por exemplo, o Excel ou o Tabletop) que também possibilitam a construção de gráficos, porém, de maneira automatizada, impedindo a efetiva compreensão das relações existentes entre os dados iniciais e o(s) gráfico(s) construído(s) a 
partir deles. Com a utilização do SuperLogo 3.0, o aluno ressignifica a construção gráfica. Para isso, ele faz relações com diferentes tipos de variáveis. Nesse momento, existe uma educação estatística fundamentada, porque o aluno está pensando sobre aquilo que está fazendo, ao ter que ensinar a tartaruga a construir, de fato, a representação gráfica, à medida que necessita analisar a variável para identificar qual a representação gráfica é mais adequada. Isso é muito diferente da utilização do Excel, por exemplo, na qual o processo é automatizado e o aluno pode apresentar representações inadequadas e equivocadas, a partir da crença de que o computador faz tudo certo.

É importante esclarecer que essas conclusões foram organizadas a partir das interpretações e análises realizadas após a construção dos gráficos, que revelaram a efetiva compreensão das relações existentes entre barras, colunas e eixos, além da proporcionalidade no gráfico de setores, de maneira a facilitar a retirada de informações e conclusões dos gráficos construídos. Os alunos foram capazes de ler os dados e, além disso, conseguiram realizar comparações, quando identificaram as relações proporcionais existentes entre gráficos. Dessa forma, acreditamos que as atividades desenvolveram as habilidades de leitura entre os dados. Os alunos utilizaram conceitos matemáticos e estatísticos de maneira adequada, o que possibilitou a retirada de informações concisas das análises realizadas. Quanto à leitura além dos dados, pela própria característica da atividade realizada, não é possível inferir constatação alguma. Todavia, quando os alunos compreendem a variabilidade e o acaso existente em qualquer investigação estatística e são capazes de ler algumas relações não explícitas nos gráficos, é evidente que eles estão a caminho de desenvolver a capacidade de ler além dos dados.

Quanto ao nível de letramento estatístico, constatamos que os alunos passaram de um nível cultural, para um nível funcional. Inicialmente, apresentavam significativa dificuldade em lidar com informações estatísticas. Na investigação realizada, construíram gráficos corretamente, bem como os leram e os interpretaram de maneira coerente e consistente.

Finalmente, acreditamos que essas habilidades caracterizam que os indivíduos atingiram o nível 2 do Alfabetismo Funcional, tendo em vista que demonstraram familiaridade com as representações gráficas e capacidade para realizar sua leitura e interpretação de forma adequada e correta. Certamente, a forma como os gráficos foram construídos facilitaram a atribuição de significado a esse tipo de representação, de modo a tornar familiar as representações estatísticas. Isso já é relevante, quando comparamos essas constatações com os resultados indicados pelo INAF 2002 e 2004. Considerando que pouco 
mais de $20 \%$ da população demonstraram saber lidar com mapas, tabelas e gráficos, a competência, em termos de reconhecimento de estruturas gráficas e tabelares, torna-se muito significativa no contexto de formação do cidadão crítico.

Não obstante, as análises realizadas evidenciaram algumas percepções das relações não explícitas, apontando para algumas habilidades do nível 3 do Alfabetismo Funcional, corroborando a relevância da atividade. É certo que esse nível não foi atingido, porque não ficou evidente a capacidade de inferir e predizer informações não explícitas nos gráficos, além do fato de não tratarmos de forma sistematizada algoritmos e cálculos, a fim de mensurar a variabilidade e, assim, avaliar a significância estatística dos resultados obtidos. Acreditamos que semelhante tipo de atividade possa/deva ser desenvolvida no Ensino Médio.

Nesse contexto, são bastante relevantes as contribuições da tecnologia para a construção, leitura e interpretação de gráficos e tabelas, especialmente o software SuperLogo 3.0. O que necessita ser mais bem pensado é a maneira de utilização das TIC como "ferramenta" diferenciadora nos processos de ensino e aprendizagem. Trata-se da compreensão e implementação do paradigma construcionista de ensino, sustentado na utilização do computador (particularmente) como meio facilitador da aprendizagem, a partir do mínimo de ensino, superando a crença de que o aperfeiçoamento da instrução, isto é, o computador como máquina de ensinar, é o caminho para a melhoria da qualidade de ensino.

\subsection{Considerações Finais e Perspectivas Futuras}

É evidente que o presente trabalho não esgota as discussões quanto à Educação Estatística no Ensino Fundamental. Ao contrário, tivemos por objetivo trazer contribuições visando a enriquecer as discussões quanto à temática em nosso país e no contexto internacional da pesquisa.

Entretanto, valemo-nos do trabalho para salientar quão enriquecedor foi o software SuperLogo 3.0 para superação/minimização da dicotomia entre construção, leitura e interpretação de gráficos. Acreditamos que essa demonstração, sim, tenha sido a grande contribuição do presente trabalho.

Alguns questionamento e apontamentos para atividades futuras necessitam ser registrados.

- O presente trabalho não tratou dos gráficos de linhas. Dessa forma, acreditamos ser relevante investigar as possibilidades e os conceitos subjacentes à construção 
desse tipo de gráfico por meio do SuperLogo 3.0, até mesmo porque a avaliação diagnóstica evidenciou substancial dificuldade dos alunos em lidar com esse tipo de representação e com dados contínuos.

- O trabalho com procedimentos no SuperLogo 3.0 é rico e favorece a mobilização do raciocínio. No entanto, não tratamos desse aspecto na sequência didática por acreditarmos que seria necessário um tempo maior (que não possuíamos) para a construção de gráficos utilizando este recurso, tendo em vista a maior complexidade que envolve a programação em linguagem LOGO a partir do recurso. Assim, acreditamos ser relevante investigar e comparar a construção gráfica a partir da construção de procedimentos, diante das considerações apresentadas neste trabalho.

- Ficou evidente a necessidade de se pensarem softwares (objetos de aprendizagem) específicos para a educação estatística, de modo a contemplar as particularidades que permeiam a Didática Estatística, em razão de não termos localizado softwares livres que apresentassem características favoráveis. Acreditamos que este seja um campo promissor para as pesquisas em Educação Estatística.

- É necessário um olhar mais cuidadoso quanto aos livros didáticos e demais materiais de apoio utilizados em sala de aula, tendo em vista que as análises preliminares ratificaram as constatações de Lopes e Moran (1999), segundo as quais as atividades neles inscritas caracterizam, muitas vezes, um reducionismo da Estatística, denotando uma supersimplificação dos conteúdos. Alguns avanços ocorreram nos últimos anos, mas as questões envolvidas ainda se limitam a leituras simples, muitas vezes enfocando cálculos numéricos, sem nenhum tratamento adequado quanto às questões mais profundas de caracterização do processo estatístico, como, por exemplo, a variabilidade onipresente em qualquer investigação.

- Outro aspecto que merece um tratamento mais cuidadoso é a questão da formação de professores, polivalentes e especialistas, no que concerne à Educação Estatística. Partindo de nossa experiência de formação, perpassando pelas pesquisas realizadas, e culminando nas conversas realizadas com as Professoras D e N, ficou evidente a insuficiência do processo de formação quanto ao ensino e aprendizagem de Probabilidade e Estatística. De fato, é necessário repensar a formação que se tem oferecido nos cursos de Licenciaturas e Pedagogias (Lopes, 2008a). Parece coerente conceber o professor como um profissional em constante formação (desde seu ingresso no curso), analisando e refletindo sobre sua prática e sobre o contexto no qual está inserido. "Saber por que se ensina, para que se ensina, para quem se ensina e como se ensina é essencial ao fazer em sala de aula" (PAIVA, 2006, p. 92). 
- Diante da insuficiência dos conhecimentos evidenciada nas análises preliminares (e nas avaliações formais), acreditamos ser importante discutir e oferecer o tratamento adequado às idéias e princípios que fundamentam a Educação Estatística, porque sem uma formação consistente quanto às particularidades dessa ciência, podem se tornar inócuos os cálculos e algoritmos (muitas vezes priorizados) que explicitem meramente o trabalho algébrico, sem considerar o contexto que atribui todo o significado na Estatística. Dessa forma, apesar da mensuração da significância e variabilidade serem fundamentais para o pleno desenvolvimento da Literacia Estatística, trabalhos, voltados ao tratamento e desenvolvimento das idéias que fundamentam esses cálculos, parece-nos de fundamental importância.

- Uma continuidade do presente trabalho no Ensino Médio (EM) poderia contemplar aspectos relacionados à mensuração da variabilidade e significância das análises aqui realizadas. Além disso, o EM pode ser um espaço para avaliação/comparação das limitações e possibilidades do trabalho com procedimentos para a construção dos gráficos no SuperLogo 3.0, pelo fato de os alunos desse nível de ensino, em sua maioria, apresentarem uma maturidade cognitiva mais consistente.

- Diante das dificuldades evidenciadas na presente pesquisa, acreditamos ser relevante a comunidade científica despender esforços visando a investigar, de forma aprofundada, a compreensão e a construção de tabelas. Os trabalhos encontrados mostraramse bastante limitados e insuficientes, enquanto este tipo de representação tem se demonstrado cada vez mais presente e importante no dia-a-dia da sociedade. Outro aspecto que pode ser explorado melhor é o papel da tecnologia neste contexto, tratando de maneira mais pontual a questão do uso do Microsoft Excel.

- As professoras D e N, assim como a Coordenadora Pedagógica e a Diretora, mostraram-se bastante céticas quanto ao desenvolvimento do trabalho, desde o início da propositura, sob a alegação de que os alunos não apresentavam maturidade suficiente, tampouco interesse e comprometimento com as atividades propostas em sala de aula, o que inviabilizaria/dificultaria o desenvolvimento da intervenção. No entanto, essa crença foi se desconstruindo à medida que os alunos se envolveram com o trabalho, participando (em quase totalidade) de todas as atividades propostas, muitas vezes superando nossas expectativas. A reação da Coordenadora, ao receber os resultados, corroborou essa desconstrução. Suas palavras externaram surpresa quanto ao potencial cognitivo e criativo dos alunos na construção dos gráficos, tabelas e na realização das análises e interpretações. "É impressionante o que você conseguiu fazer, professor", disse a coordenadora. Nós nos 
sentimos na obrigação de realizar uma pequena correção, afirmando que a autoria do trabalho era dos alunos, sendo que nós, enquanto professor/pesquisador, apenas mediamos as ações, proporcionando espaços de reflexão, explicitação de idéias, troca de experiências e, por conseguinte, construção de conhecimento. Trata-se da superação da compreensão do computador como uma máquina com fim em si próprio, concebendo-o como um "meio" para a aprendizagem. Acreditamos que esse relato retrata e fundamenta a atitude da coordenação em se preocupar mais com a questão da tecnologia no ensino e o modo como isso vem sendo tratado e contemplado em sala de aula.

Finalmente, ficamos com a certeza de que a presente investigação não sistematiza um modelo, ou contempla todas as discussões quanto à Educação Estatística no Ensino Fundamental. Trata-se de uma pesquisa que aponta algumas possibilidades e alternativas, com o objetivo de contribuir para o desenvolvimento da "nova" forma de linguagem da sociedade contemporânea, de modo a proporcionar que a escola possa, de fato, desempenhar sua função social de inserir cada indivíduo no contexto que o cerca, proporcionando-lhe igualdade de oportunidades para que se construa como sujeito crítico e participativo, tendo vista os dados do INAF, por exemplo, que evidenciam a pouca habilidade de pessoas adultas em lidar com representações gráficas. A Estatística exerce significativa contribuição para isso. Dessa constatação, decorre a relevância singular dessa ciência para a Educação formal. 


\section{REFERÊNCIAS}

ALMOULOUD, S. A. Fundamentos da didática da matemática. Curitiba: Ed. UFPR, 2007.

ALMOULOUD, S. A.; COUTINHO, C. Q. S. Engenharia Didática: características e seus usos em trabalhos apresentados no GT-19 / ANPEd. Revista Eletrônica de Educação Matemática - REVEMAT, v. 3.6, p. 62-77, UFSC, 2008.

American Statistical Association (ASA). Guidelines for Assessment and Instruction in Statistics Education (GAISE) Report: A Pre-K-12 Curriculum Framework. Alexandria, 2005. disponível em: < http://www.amstat.org/education/gaise/GAISEPreK12_Intro.pdf>. Acesso em 10 abr. 2009.

ARAUJO, E. G.; FLORES, C. R. O Tratamento da Informação nas séries inicias - Uma proposta de formação de professores para o ensino dos gráficos e tabelas. In: IX Encontro Nacional de Educação Matemática, Belo Horizonte, 2007.

BATANERO, C. Didáctica de la Estadística. Granada. Uninersidad de Granada, Espanha, 2001.

BELlONI, M. L. O que é Mídia-Educação. Campinas: Autores Associados, 2001.

BONILLA, M. H. S.; PRETTO, N. D. L. Políticas Brasileiras de Educação e Informática, 2000. Disponível em: <http://www.faced.ufba.br/ bonilla/politicas.html $>$. Acesso em 16 jul. 2008.

BRASIL. Parâmetros curriculares nacionais: matemática $\left(1^{\circ}\right.$ e $2^{\circ}$ ciclos do Ensino Fundamental). Ministério da Educação. Secretaria de Educação Fundamental. Brasília: MEC/SEF, 1997.

Parâmetros curriculares nacionais: matemática $\left(3^{\circ}\right.$ e $4^{\circ}$ ciclos do Ensino Fundamental). Ministério da Educação. Secretaria de Educação Fundamental. Brasília: MEC/SEF, 1998.

BROUSSEAU, G. La théorie des situations didactiques. 1997. Disponível em: <http:// pagesperso-orange.fr/daest/guy-brousseau/textes/TDS_Montreal.pdf $>$. Acesso em: $10 \mathrm{dez}$. 2009.

BUEHRING, R. S.; FLORES, C. R; MORETTI, M. T. O tratamento da informação nos livros didáticos e a teoria dos registros de representação semiótica. In: REREMAT - Revista Eletrônica de Republicação em Educação Matemática. UFSC, p. 24-32, 2005.

CAMPOS, M. A. Introdução ao tratamento da informação nos ensinos fundamental e médio. São Paulo: Plêiade, 2005. (Notas em Matemática Aplicada 16 - SBMAC).

CASTANHEIRA, N. P. Estatística aplicada a todos os níveis. 3 ed. Curitiba: Ibpex, 2006.

CAZORLA, I. M. A relação entre habilidade viso-pictórica e o domínio de conceitos estatísticos na leitura de gráficos. Tese (Doutorado). Faculdade de Educação da UNICAMP, Campinas, 2002. $315 \mathrm{f}$. 
COSTA, S. C. H. O raciocínio proporcional dos alunos do 2. Ciclo do Ensino Básico. Dissertação (mestrado). Universidade de Lisboa, Portugal, 2007. 140 f.

COUTINHO, C. Q. S. Introduction aux situations aléatoires dès le college: de la modélisations à la simultions d'expériences de Bernoulli dan l'environnement informatique Cabri-géométrei II. Tese (Doutorado). Université Joseph Fourier, Grenoble I, França, 2001. $330 \mathrm{f}$.

CRESPO, A. A. Estatística Fácil. São Paulo: Saraiva, 1999.

CURCIO F. R. Comprehension of mathematical relationship expressed in graphs. Journal for Research in Mathematics Education, National Council of Teachers of Mathematics, v.18, n.5, 1987, p. 382-393. Disponível em: < http://www.jstor.org/stable/749086>. Acesso em: 09 jun. 2009.

CYRINO, M. C. de C. T. Preparação e emancipação profissional na formação inicial do professor de matemática. In: NACARATO, A. M.; PAIVA, M. A. V. (org.) A formação do professor que ensina Matemática: perspectivas e pesquisas. Belo Horizonte: Autêntica, 2006.

DUVAL, R. Registro de representações semióticas e funcionamento cognitivo da compreensão em matemática. In: MACHADO, S. D. A. (Org.). Aprendizagem em Matemática: registro de representação semiótica. Campinas: Papirus, 2003.

FLORES. C. R.; MORETTI, M. T. O funcionamento cognitivo e semiótico das representações gráficas: Ponto de análise para a aprendizagem. In: Anais $\mathbf{2 8}^{\mathbf{a}}$ Reunião Anual da ANPED, 2005. Disponível em: <http://www.anped.org.br/reunioes/28/inicio.htm>. Acesso em: 13 nov. 2009.

GAL, I. Adult's Statistical Literacy: meanings, components, responsibilities. International Statistical Revew, v. 70, n. 1, p. 1-25, 2002.

GARFIELD, J. B.; GAL, I. Teaching and Assessing Statistical Reasoning. In: STIFF, L. ; CURCIO. F. Developing Mathematical Reasoning in Grades K-12. USA: The National Council of Teachers of Mathematics, 1999. p. 207-219

GARFIELD, J. Assessing Statistical Reasoning. Statistics Education Research Journal. v. 2. n. 1.20 p. 22-38, 2003. Disponível em: < http://www.stat.auckland.ac.nz/ iase/serj/SERJ2(1).pdf>. Acesso em: 16 set. 2009.

. How Students Learn Statistics. International Statistical Review, Mexico, v. 63, n. 1, p. 25-34, 1995.

GREGOLIN, V. R. Linguagem LOGO: explorando conceitos matemáticos. Revista Tecnologias da Educação, v. 1, n. 1, 2008. Disponível em: $<$ http://tecnologiasnaeducacao.pro.br/revista/a1n1/art8.pdf > . Acesso em: 04 nov. 2009.

GRISPUN, M. P. S. Z. (Org.). Educação Tecnológica: desafios e perspectivas. São Paulo: Cortez, 1999. 
GUIMARÃES, G. Interpretando e construindo gráficos de barras. Tese (Doutorado). Universidade Federal de Pernambuco, Recife, 2002. $258 \mathrm{f}$.

HERNANDES, V. K. Analisando e avaliando os softwares educacionais. In: ALMEIDA, F. J. de. Introdução à informática para educadores (Módulo I). São Paulo: PUC, 1998.

INSTITUTO PAULO MONTENEGRO (IPM). INAF: $\mathbf{2}^{\mathbf{0}}$ Indicador Nacional de Alfabetismo Funcional: um diagnóstico para inclusão social - Atividade Matemática primeiros resultados. São Paulo, 2002. Disponível em: <HTTP://www.ipm.org.br>. Acesso em: 02 out. 2009.

INSTITUTO PAULO MONTENEGRO (IPM). INAF: $4^{\mathbf{0}}$ Indicador Nacional de Alfabetismo Funcional: um diagnóstico para inclusão social pela educação - Avaliação de Habilidades Matemáticas. São Paulo, 2004. Disponível em: <HTTP://www.ipm.org.br>. Acesso em: 02 out. 2009.

LOPES, C. A. E. A probabilidade e a estatística no ensino fundamental: uma análise curricular. Dissertação (Mestrado). Faculdade de Educação da UNICAMP, Campinas, 1998. $127 \mathrm{f}$.

Literacia estatística e o INAF 2002. In: FONSECA, M. C. F. R. (Org.). Letramento no Brasil: Habilidades Matemáticas - reflexões sobre o INAF 2002. São Paulo: Global Editora, 2004.

. O conhecimento profissional dos professores e suas relações com estatística

e probabilidade na educação infantil. Tese (Doutorado). Faculdade de Educação da UNICAMP, Campinas, 2003. $289 \mathrm{f}$.

. O ensino da estatística e da probabilidade na educação básica e a formação dos professores. Cad. Cedes, Campinas, vol. 28, n. 74, p. 57-73, jan./abr. 2008 a.

. Reflexões teórico-metodológicas para a Educação Estatística. In: LOPES, C. E.; CURI, E. (Org.) Pesquisas em Educação Matemática: Um encontro entre a teoria e a prática. São Carlos: Pedro \& João Editores, 2008 b.

LOPES, C. E.; CARVALHO, C. Literacia estatística na educação básica. In: NACARATO, A. M.; LOPES, C. E. (Org.). Escritas e Leituras na Educação Matemática. Belo Horizonte: Autêntica, 2009.

LOPES, C. E.; COUTINHO, C. Q. S. Leitura e escrita em educação estatística. In: LOPES, C. E.; NACARATO, A. M. (Org.). Educação Matemática, Leitura e Escrita: armadilhas, utopias e realidade. Campinas: Mercado das Letras, 2009.

LOPES, C. A. E.; MORAN, R. C. C. P. A Estatística e a Probabilidade através das Atividades Propostas em Alguns Livros Didáticos Brasileiros Recomendados para o Ensino Fundamental. In: Conferência Internacional Experiências e Expectativas do Ensino de Estatística - Desafios do Século XXI. Santa Catarina, 1999. 
MACHADO, S. D. A. Engenharia Didática. In: MACHADO, S. D. A. (Org.) Educação Matemática: uma (nova) introdução. 3. ed. São Paulo: EDUC, 2008.

Magalhães, M. N.; LIMA, A. P. L. Noções de Probabilidade e Estatítica. 6 ed. São Paulos: EDUSP, 2004.

MAGINA, S. M. P.; GITIRANA, V. Interpretação de gráficos e diagramas em ambiente computacional de manipulação de dados. Projeto temático CNPq, Processo $\mathrm{N}^{\circ}$ 521446/953, 1998.

MARUCI, F. A. S. Sistema de Avaliação do Rendimento Escolar do Estado de São Paulo SARESP: uma discussão sobre o modelo de competências e habilidades. In: $\mathbf{1 6}^{\mathbf{0}}$ Congresso de Leitura do Brasil. Campinas, 2007. Disponível em: < http://www.alb.com.br/anais16/sem03pdf/sm03ss03_06.pdf>. Acesso em: 25 Maio 2009.

MORAIS, T. M. R. Um estudo sobre o pensamento estatístico: componentes e habilidades. Dissertação (Mestrado). Pontifícia Universidade Católica de São Paulo, São Paulo, 2006. $136 \mathrm{f}$.

MORELATTI, M. R. M. Criando um ambiente construcionista de aprendizagem em cálculo diferencial e integral $\mathbf{l}$. Tese (Doutorado em Educação). Pontifícia Universidade Católica de São Paulo, São Paulo, 2001. 260 f..

PAIVA, M. A. V. O professor de Matemática e sua formação: a busca da identidade profissional. In: NACARATO, A. M.; PAIVA, M. A. V. (Org.) A formação do professor que ensina Matemática: perspectivas e pesquisas. Belo Horizonte: Autêntica, 2006. p. 89111.

PAPERT, S. A máquina das crianças: repensando a escola na era da informática. Porto Alegre: Artes Médicas, 1994.

Logo: Computadores e Educação. São Paulo: Brasiliense, 1985.

PESTANA, M. I. O sistema de avaliação brasileiro. Revista Brasileira de Estudos Pedagógicos, Brasília, vol. 79, n. 191, p. 65-73, 1998.

POLYA, G. A arte de resolver problemas. Rio de janeiro: Interciências, 1986.

POMMER, W. M. Brousseau e a Ideia de Situação Didática. In: Seminários de Ensino de Matemática/FEUSP, São Paulo, 2008. Disponível em: <http://www.nilsonmachado. net/sema20080902.pdf $>$. Acesso em: 05 Jan. 2010.

REBElO, R. A. ; KOVATLI, M. de F.; BARBETTA, P. A. Uma Metodologia Para o Ensino de gráficos Estatísticos utilizando Planilhas Eletrônicas. In: II Congresso Brasileiro de Computação. Itajaí, 2002.

RIBEIRO, J. O. Leitura e interpretação de gráficos e tabelas: um estudo exploratório com Professores. Dissertação (Mestrado Profissional em Ensino de Matemática). Pontifícia Universidade Católica de São Paulo, São Paulo. 2007. 167 f. 
RUMSEY, D. J. Statistical literacy as a goal for introductory statistics courses. Journal of Statistics Education, v. 10, n. 3, 2002. Diposnível em: <http://www.amstat.org/ publications/jse/v10n3/rumsey2.html>. Acesso em: 08 dez. 2009.

SANTOS, C. R. O tratamento da informação: currículos prescritos, formação de professores e implementação na sala de aula. Dissertação (Mestrado Profissional em Ensino de Matemática). Pontifícia Universidade Católica de São Paulo, São Paulo, 2005. 126 f.

SANTOS, S. S. A formação do professor não especialista em conceitos elementares do bloco tratamento da informação: um estudo de caso no ambiente computacional. Dissertação (Mestrado). Pontifícia Universidade Católica de São Paulo, São Paulo, 2003. 307 f.

SANTOS, S. S.; MAGINA, S. M. P. A Manipulação e Interpretação Gráfica na Visão dos Professores das Séries Iniciais do Ensino Fundamental: Um Estudo de Caso. In: BRITO, M. R. F. (Org.). Solução de Problemas e a Matemática Escolar. Campinas: Editora Alínea, 2006.

SÃO PAULO. SECRETARIA DE EDUCAÇÃO. Proposta curricular para o ensino de matemática: $1^{\circ}$ grau. 3. Ed. São Paulo: SE/CENP, 1988.

SÃO PAUlO (Estado). Resolução SE $\mathbf{n}^{\mathbf{0}}$ 89, de 2005. Disponível em: $<$ http://siau.edunet.sp.gov.br/ItemLise/arquivos/89_09.HTM?Time=1/3/2010\%208:57:38\%20 $\mathrm{PM}>$. Acesso em: 05 out. 2008.

SÃO PAUlO. SECRETARIA DE EDUCAÇÃO DO ESTADO DE SÃO PAULO. Proposta curricular do estado de São Paulo. Matemática. Ensino Fundamental - Ciclo II e Ensino Médio. São Paulo: SEE/SP. Disponível em: <http://www.rededosaber.sp.gov.br /contents/SIGS-CURSO/sogsc/upload/br/site_25/File/Prop_MAT_COMP_red_md_20_03.pdf >. Acesso: em 03 mai. 2008.

SILVA, C. B. Pensamento estatístico e raciocínio sobre variação: um estudo com professores de matemática. Tese (Doutorado). Pontifícia Universidade Católica de São Paulo, São Paulo, 2007. 354 f.

TORINO, C.; MENDES, C. R. Avaliação Educacional e educação Estatística - um olhar sobre os resultados do Saresp. In: Anais do XIV Encontro de Iniciação Científica da PUCCampinas. Campinas, 2009. Disponível em: <http://www.puccamp.br/pesquisa/ic/pic2009/ resumos/2009825_01123_207359143_res7AB.pdf>. Acesso em: 25 maio 2009.

VALENTE, J. A. A espiral da aprendizagem e as Tecnologias de Informação e Comunicação: repensando conceitos. In: JOLY, M. C. R. A. A tecnologia no ensino: implicações para aprendizagem. São Paulo: Casa do Psicólogo, 2002. p. 15-37.

VALENTE, J. A. Análise dos diferentes tipos de software usados na educação. In: . (Org.). O computador na sociedade do conhecimento. Campinas: UNICAMP/Nied, 1999. p. 89-100. 
Computadores e conhecimento: repensando a educação. Campinas: Gráfica Central da UNICAMP, 1993.

VYGOTSKY, L. S. A formação social da mente. São Paulo: Martins Fontes, 1989.

WAINER, H. Understanding graphs and tables. Educacional Research, 21, 14-23. 1992.

ZABALA, A. A Prática Educativa. Porto Alegre: Artes Médicas, 1998. 
APÊNDICES 


\section{APÊNDICE A - Instrumento Diagnóstico elaborado a partir das orientações de Curcio (1987)}

\section{Inventário de Conhecimentos Prévios 1}

Caro Aluno,

O objetivo deste estudo é identificar sua familiaridade com os conceitos e questionamentos indicados abaixo. Cada questão requer que você raciocine, relembre informações estudadas em outras séries ou disciplinas e analise as informações abaixo com atenção e cuidado, de forma a fundamentar sua opção de acordo com a sua compreensão pessoal das informações.

1. O que você entende por "população"?

(a) O crescimento de habitantes de um lugar, região ou país

(b) A diferença entre o número de pessoas que nascem e que morrem num determinado lugar, região ou pais

(c) O conjunto dos habitantes de determinado lugar, região ou pais

$\square$ (d) Grande número de habitantes num determinado lugar, região ou pais

2. O que influencia o crescimento (ou decrescimento) de uma população?

(a) A descendência genética

(b) As condiçőes do ambiente em que se encontra a população

(c) A área disponivel para a população ocupar

$\square$ (d) Taxa de natalidade (nascimentos),

mortalidade (mortes) e expectativa de vida

3. Ao afirmar que $\mathrm{A}$ (conjunto) é um subconjunto de um conjunto $B$, podemos concluir que:

(a) A e B são o mesmo conjunto

(b) Todo elemento do conjunto $B$ também é um elemento do conjunto $\mathrm{A}$

(c) $\mathrm{O}$ conjunto $\mathrm{B}$ é menor ou igual ao conjunto $\mathrm{A}$

(d) Nenhuma das alternativas anteriores

4. Se eu nasci no ano de 1972 , quantos anos eu terei no ano de 2020 ?

$\square$ (a) 28
$\square$ (b) 48
$\square$ (c) 20
$\square$ (d) 92

Utilize o gráfico abaixo para responder às questões 5,6 e 7 .

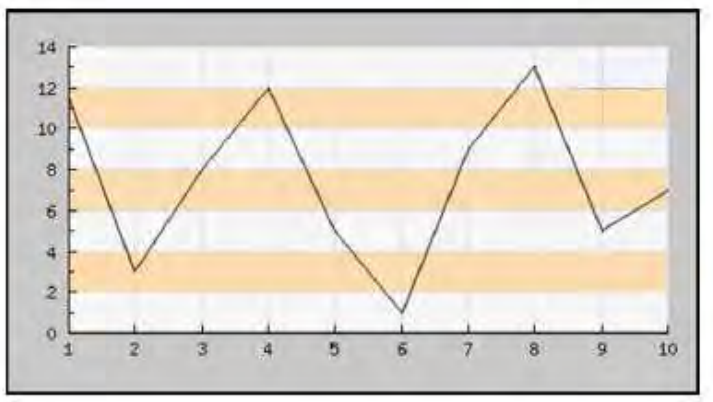

5. Qual é a maior e a menor quantidade representada no gráfico?
$\square$ (a) 10 e 3 , respectivamente
(b) 13 e 1, respectivamente
(c) 12 e 5 , respectivamente
(d) 11 e 7 , respectivamente

6. De acordo com o gráfico, é correto afirmar que:

$\square$ (a) Os dados cresceram no intervalo de 1 a 10

(b) Os dados diminuiram no intervalo de 1 a 10

(c) Os dados variaram no intervalo de 1 a 10

(d) Os dados permaneceram constantes no intervalo de 1 a 10

7. De acordo com o gráfico, onde existe decrescimento?
(a) 2 a $4 ; 6$ a $8 ; 9$ a 10
(b) 1 a 2; 4 a 6; 8 a 9
(c) 1 a $2 ; 4$ a $6 ; 9$ a 10
(d) Não existe decrescimento 


\section{Avaliação Diagnóstica 1}

Caro aluno,

O objetivo deste estudo é o de indicar a forma como você interpreta informações apresentadas em seu dia-a-dia. Cada questão requer que você raciocine e analise as informações apresentadas com atenção e cuidado, de forma a fundamentar sua opção de acordo com a sua compreensão pessoal das informações.

Os gráficos abaixo, retirados de uma matéria da Revista Época, devem ser utilizadas para responder as questōes apresentadas a seguir.

\section{QUANTOS SEREMOS EM 2020}
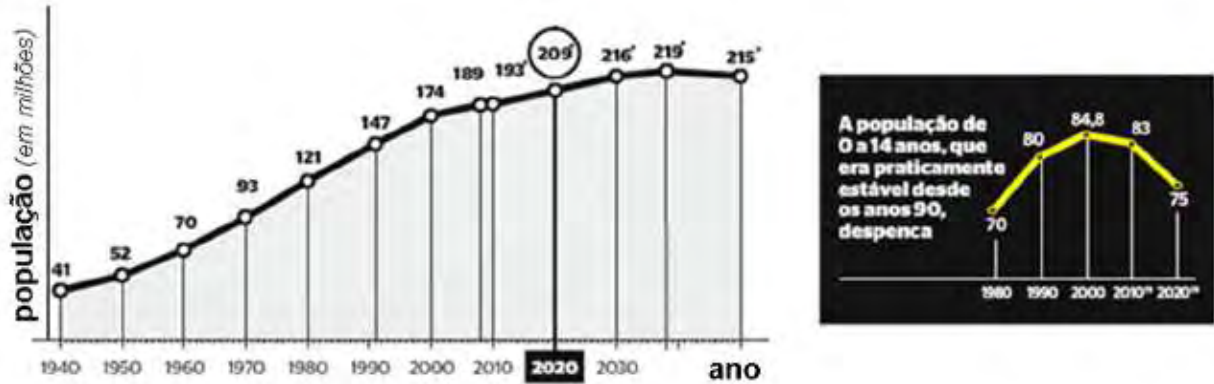

thometict

Fonte: Adaptado da Revista Epoca № 575 , de 25 de maio de 2009.

1. Qual o assunto tratado nos gráficos acima?

$\square$ (a) O crescimento da população brasileira

(b) A evolução do capital (dinheiro) brasileiro

(c) A importância do ano de 2020 para a população brasileira

(d) A variação da população brasileira

2. Indique qual das frases abaixo pode ser considerada correta:

$\square$ (a) A população brasileira cresce e crescerá continuamente

(b) A população brasileira deixará de crescer daqui a uns 30 anos

$\square$ (c) A população de 0 a 14 anos aumentou continuamente

(d) A população de 0 a 14 anos sempre foi constante 
3. Qual a população brasileira em 1960 e a população brasileira estimada para 2030 , respectivamente?

(a) 41 milhões e 215 milhões

(b) 70 milhões e 216 milhões

(c) 121 milhões e 209 milhões

(d) Não é possível determinar

4. No período compreendido entre 2000 e 2020 , qual será a variação da população brasileira e da população de 0 a 14 anos, respectivamente?

(a) aumento de 35 milhôes e aumento de 9,8 milhões

(b) aumento de 35 milhões e diminuição de 9,8 milhões

(c) diminuição de 35 milhões e diminuição de 9,8 milhões

(d) diminuição de 35 milhões e aumento de 9,8 milhões

5. De acordo com os gráficos acima, é possivel afirmar que:

(a) Apesar de a população brasileira crescer continuamente, a população de 0 a 14 anos diminuirá nos próximos anos

(b) Tanto a população brasileira quanto a de 0 a 14 anos crescerão nos próximos anos

(c) Tanto a população brasileira quanto a de 0 a 14 anos diminuirão nos próximos anos

(d) Apesar da população de 0 a 14 anos estar diminuindo desde o ano 2000 , a população brasileira só começará a diminuir no ano 2040, aproximadamente

6. No que diz respeito à população, podemos concluir que a partir de 2040 , provavelmente:

(a) A população brasileira aumentará

(b) A população brasileira diminuirá

(c) A população brasileira aumentará até 2050

(d) A população brasileira diminuirá até 2050 


\section{Inventário de Conhecimentos Prévios 2}

Caro aluno,

O objetivo deste estudo é identificar sua familiaridade com os conceitos e questionamentos indicados abaixo. Cada questão requer que você raciocine, relembre informações estudadas em outras séries ou disciplinas e analise as informações abaixo com atenção e cuidado, de forma a fundamentar sua opção de acordo com a sua compreensão pessoal das informações.

1. O que pode ser considerado "violência"?

$\square$ (a) Homicídios, roubos e lesões corporais

$\square$ (b) Discussão, contradição e discordância

(c) Diálogo, afeto e abraço

(d) Homossexualismo e o uso de drogas

2. De acordo com a sua compreensão de índice de violência, qual das afirmações abaixo está correta?

(a) Quanto maiores os índices de violência, melhor é a qualidade de vida do lugar

(b) Quanto maiores os índices de violência, pior é a qualidade de vida do lugar

$\square$ (c) Quanto menores os indices de violência, pior é a qualidade de vida do lugar

(d) Não é possível afirmar nada sem

conhecermos numericamente esses índices

3. "De cada 10.000 pessoas, 50 sofreram violência nos últimos 10 anos". De acordo com essa afirmação, podemos concluir que o percentual de pessoas que sofreram violência é de:
(a) $0,05 \%$
(b) $0,5 \%$
(c) $5 \%$
(d) $50 \%$

4. Indique a proporção entre as grandezas $36 \mathrm{e}$ 24 ?
(a) $\frac{1}{2}$
(b) $\frac{3}{4}$
(c) $\frac{3}{2}$
(d) $\frac{4}{3}$

Utilize o gráfico abaixo para responder às questões 5,6 e 7 .

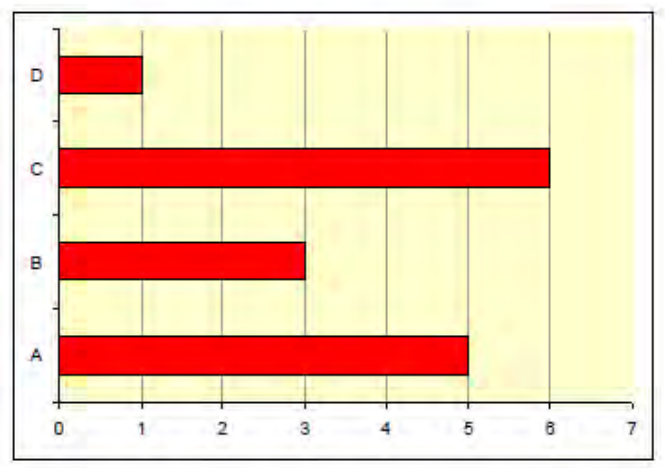

5. Qual barra representa a maior quantidade?
(a) A
(b) B
(c) C
(d) D

6. A barra B representa qual quantidade?
(a) 2
(b) 4
(c) 3
(d) 1

7. Quantas barras representam menos que 6 ?
$\square$ (a) 0
(b) 1
(c) 2
(d) 3 


\section{Avaliação Diagnóstica 2}

Caro aluno,

O objetivo deste estudo é o de indicar a forma como você interpreta informações apresentadas em seu dia-a-dia. Cada questão requer que você raciocine e analise as informações apresentadas com atenção e cuidado, de forma a fundamentar sua opção de acordo com a sua compreensão pessoal das informações.

Os gráficos abaixo, retirados de uma matéria do Jornal Folha de São Paulo que traz informações acerca das capitais brasileiras candidatas a serem sedes da copa de 2014, devem ser utilizados para responder as questões apresentadas a seguir.

\section{CHAMA A POLÍCIA}

Îndices de violência das candidatas a 2014
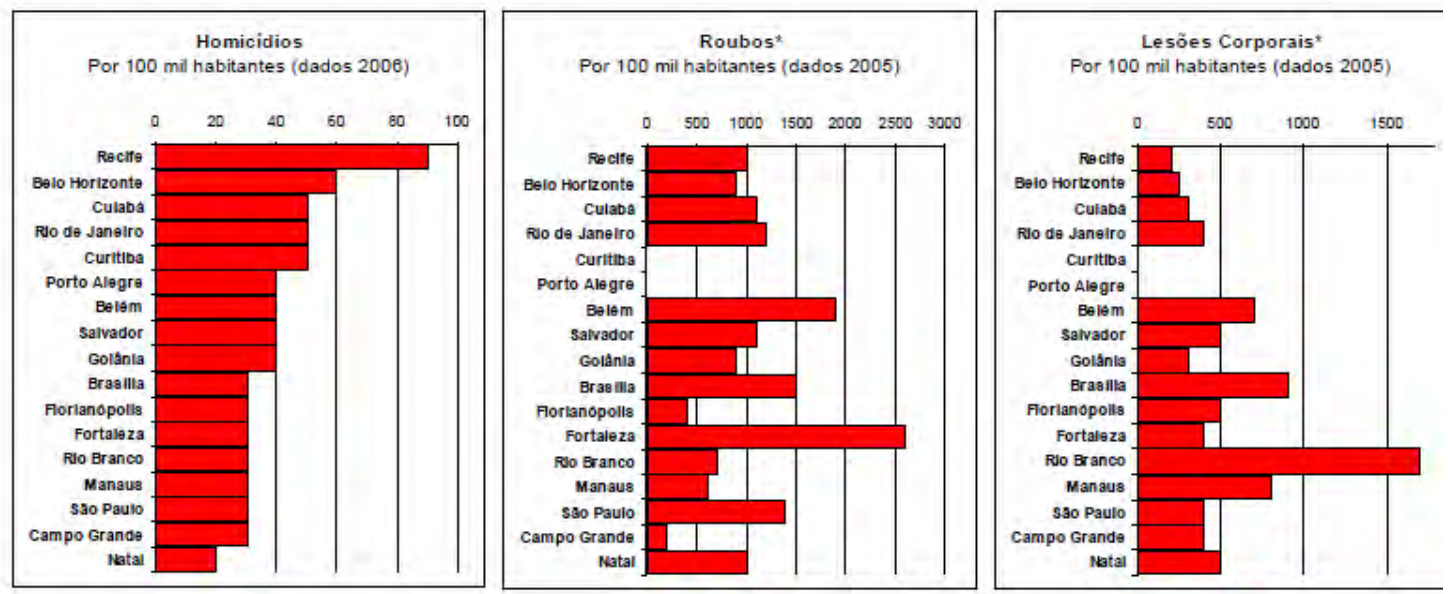

- Dados não disponiveis para Curitiba e Porto Alegre

Fonte: Adaptado do Jornal Folha de São Paulo de 30 de maio de 2009.

1. Qual o assunto tratado nos gráficos acima?

$\square$ (a) Os índices de violência de algumas capitais brasileiras

(b) A população (número de habitantes) de algumas capitais brasileiras

(c) A influência da polícia para os índices de violência de algumas capitais brasileiras

(d) A estimativa da população (número de habitantes) de algumas capitais brasileiras em 2014

2. Os menores índices de homicídios, roubos e lesões corporais estão em:

(a) Recife, Fortaleza e Rio Branco, respectivamente

(b) Natal (homicidios), Curitiba e Porto Alegre (empatadas nos índices de roubos e lesôes corporais) 
(c) Natal, Campo Grande e Recife, respectivamente

(d) São Paulo, Rio e Janeiro e Belo Horizonte, respectivamente

3. Comparando Recife e Natal, concluimos que a diferença dos indices de homicidios, roubos e lesões corporais, respectivamente, em termos de 100 mil habitantes é de aproximadamente

$\square$ (a) 70,100 e 300 habitantes em cada 100 mil, respectivamente

(b) 20,1000 e 500 habitantes em cada 100 mil, respectivamente

$\square$ (c) 90,1000 e 190 habitantes em cada 100 mil, respectivamente

(d) 70, 0 e 300 habitantes em cada 100 mil, respectivamente

4. Considerando os índices apresentados nos gráficos, podemos concluir que:

(a) Como o índice de homicídios em Recife é o maior, a cidade de Recife é um bom lugar para se residir

(b) Campo Grande é uma boa cidade para se morar porque apresenta índices de violência baixos, em comparação com as demais capitais

(c) Brasilia é uma boa cidade para se morar porque apresenta indices semelhantes nos três gráficos

(d) São Paulo só difere de Campo Grande em termos de roubo, apresentando indice que caracteriza sua superioridade em termos de qualidade de vida e segurança

5. Em termos percentuais, é correto afirmar que os índices de homicídios, roubos e lesões corporais da cidade de São Paulo são aproximadamente?
(a) $0,03 \%, 1,4 \%$ e $0,4 \%$
(c) $3 \%, 14 \%$ e $4 \%$
(b) $30 \%, 1400 \%$ e $400 \%$
$\square$ (d) $90 \%, 1000 \%$ e $190 \%$

6. Em termos proporcionais, podemos afirmar que os índices de São Paulo e Rio de Janeiro apresentam aproximadamente as seguintes proporções para homicídios, roubos e lesões corporais:
(a) $\frac{5}{10}, \frac{9}{8}$ e $\frac{1}{2}$, respectivamente
(c) $\frac{3}{5}, \frac{7}{6}$ e 0 , respectivamente
(b) $\frac{2}{3}, \frac{6}{5}$ e $\frac{3}{4}$, respectivamente
(d) $\frac{3}{5}, \frac{7}{6}$ e 1 , respectivamente 


\section{Inventário de Conhecimentos Prévios 3}

Caro aluno,

O objetivo deste estudo é identificar sua familiaridade com os conceitos e questionamentos indicados abaixo. Cada questâo requer que você raciocine, relembre informações estudadas em outras séries ou disciplinas e analise as informações abaixo com atenção e cuidado, de forma a fundamentar sua opção de acordo com a sua compreensão pessoal das informações.

1. O que você entende por analfabetismo?

(a) Incapacidade para o trabalho

(b) Capacidade de ler e escrever

(c) Impossibilidade de estudar

(d) Incapacidade de ler e escrever

2. Para você, podem existir diferenças entre os indices de analfabetismo das regiões brasileiras? Por quê?

(a) Não, porque por se tratar de um único país, as condições são as mesmas em todas as regiões

(b) Sim, porque por se tratar de um pais com grande extensão algumas regiões apresentam quadros de desenvolvimento muito diferentes de outras

(c) Não, porque a distribuição das riquezas brasileiras é igualitária entre as regiões

(d) Não tenho conhecimento dessas informações

\section{Quanto é $30 \%$ de 360 ?}
$\square$ (a) 36
$\square$ (b) 72
$\square$ (c) 108
(d) 144

4. Quantos graus tem uma circunferência completa:
(a) $360^{\circ}$
(b) $180^{\circ}$
(c) $90^{\circ}$
(d) $0^{\circ}$

5. Quantos graus tem o ângulo $\theta$ abaixo?
(a) $90^{\circ}$
(b) $100^{\circ}$
(c) $135^{\circ}$
(d) $260^{\circ}$

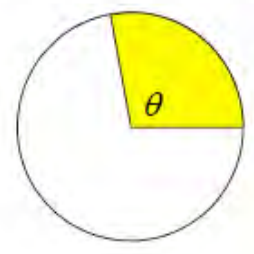

Utilize o gráfico abaixo para responder às questões 6 e 7 .

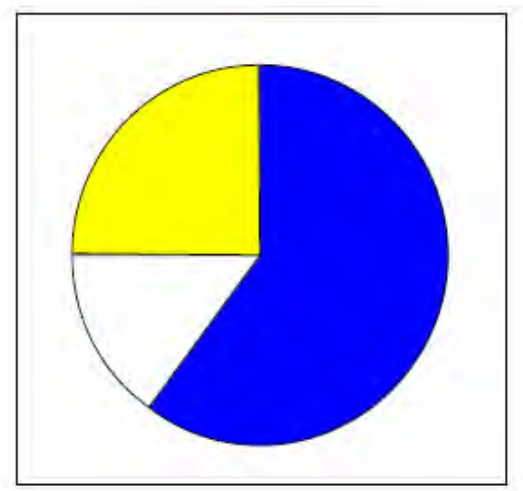

6. Qual cor representa a maior quantidade?
(a) Amarelo
$\square$ (b) Branco
(c) Azul
(d) Nenhuma das alternativas

7. Em termos percentuais, quanto a região azul representa do total:
(a) $15 \%$
(b) $25 \%$
(c) $60 \%$
(d) $75 \%$ 


\section{Avaliação Diagnóstica 3}

Caro Aluno,

O objetivo deste estudo é o de indicar a forma como você interpreta informaçőes apresentadas em seu dia-a-dia. Cada questão requer que você raciocine e analise as informações apresentadas com atenção e cuidado, de forma a fundamentar sua opção de acordo com a sua compreensão pessoal das informações.

Os gráficos abaixo, adaptados do site do IBGE, devem ser utilizados para responder as questốes apresentadas a seguir.

\section{Pesquisa Nacional por Amostra de Domicílio de 2008}
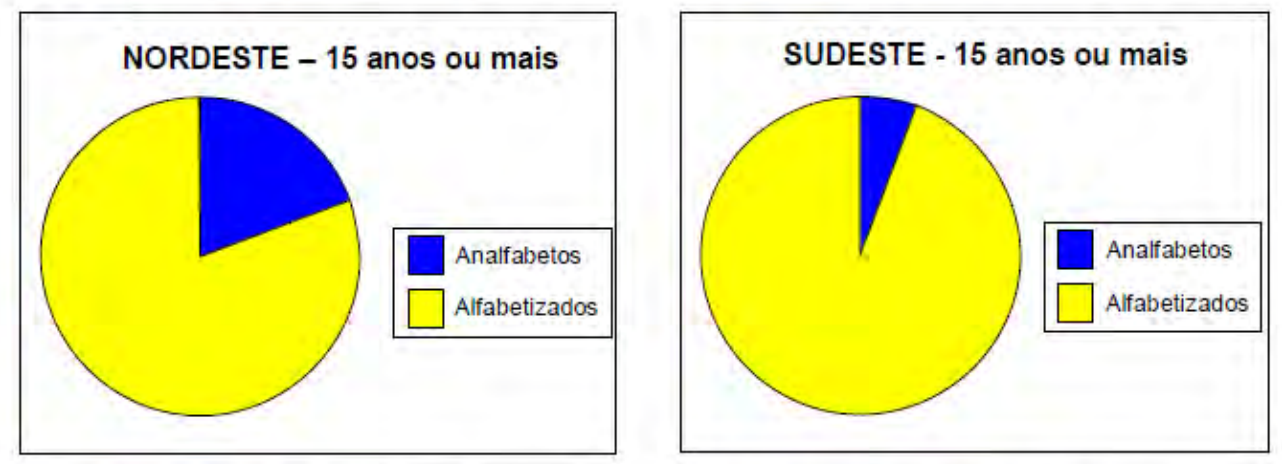

Fonte: Adaptado do site do IBGE da Pesquisa Nacional por Amostra de Domicilios de 2008. Disponivel em: <http://www.ibge.gov.br/graficos_dinamicos/pnad2008/educacao.html>. Acesso em: 18 set. 2009.

1. Qual o assunto tratado nos gráficos acima?

$\square$ (a) İndice de Mortalidade Infantil no Brasil

$\square$ (b) Índice de Analfabestismo em duas regióes brasileiras das pessoas com menos de 15 anos

(c) Índice de Analfabestismo em duas regióes brasileiras das pessoas com mais de 15 anos

$\square$ (d) Índices de desempenho educacional no Sudeste e Nordeste

2. Qual das Regiỏes apresenta indices mais preocupantes em termos educacionais:

$\square$ (a) Nordeste

$\square$ (b) Sudeste

$\square$ (c) As duas apresentam, praticamente, os mesmos índices

$\square$ (d) Não é possivel responder a esta questão com as informações dos gráficos 
3. Qual é o índice de analfabetismo (em percentual aproximado) do Nordeste:

$\square$ (a) $20 \%$

$\square$ (b) $70 \%$

(c) $80 \%$

$\square$ (d) Não é possivel responder a esta questão com as informações dos gráficos

4. Qual é o índice de pessoas alfabetizadas (em percentual aproximado) na região Sudeste:

$\square$ (a) $5 \%$

(b) $20 \%$

$\square$ (c) $95 \%$

$\square$ (d) Não é possivel responder a esta questão com as informações dos gráficos

5. Podemos dizer que a diferença em percentual dos índices de analfabetismo do Nordeste e do Sudeste é de:
(a) $50 \%$
(b) $30 \%$
(c) $15 \%$
(d) $5 \%$

6. Se considerarmos que nas pesquisas que deram origem aos gráficos foram entrevistadas 1 milhão de pessoas em cada região, então constatamos que existem quantos analfabetos nas regiões sudeste e nordeste, respectivamente:
(a) $500 \mathrm{mil} \mathrm{e} 100 \mathrm{mil}$
(b) 800 mil e $950 \mathrm{mil}$
(c) 20 mil e 5 mil
$\square$ (d) $200 \mathrm{mil} \mathrm{e} 50 \mathrm{mil}$ 

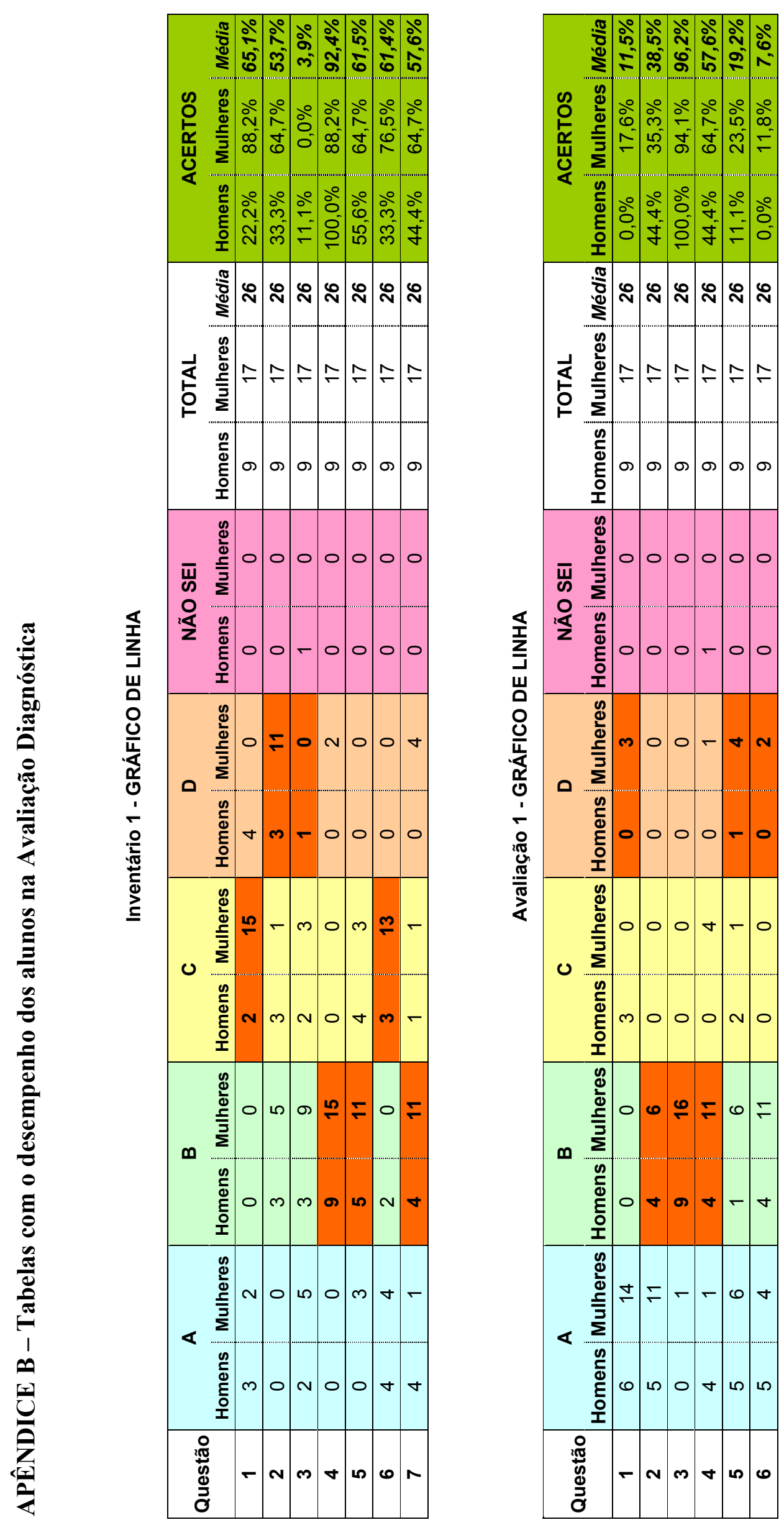

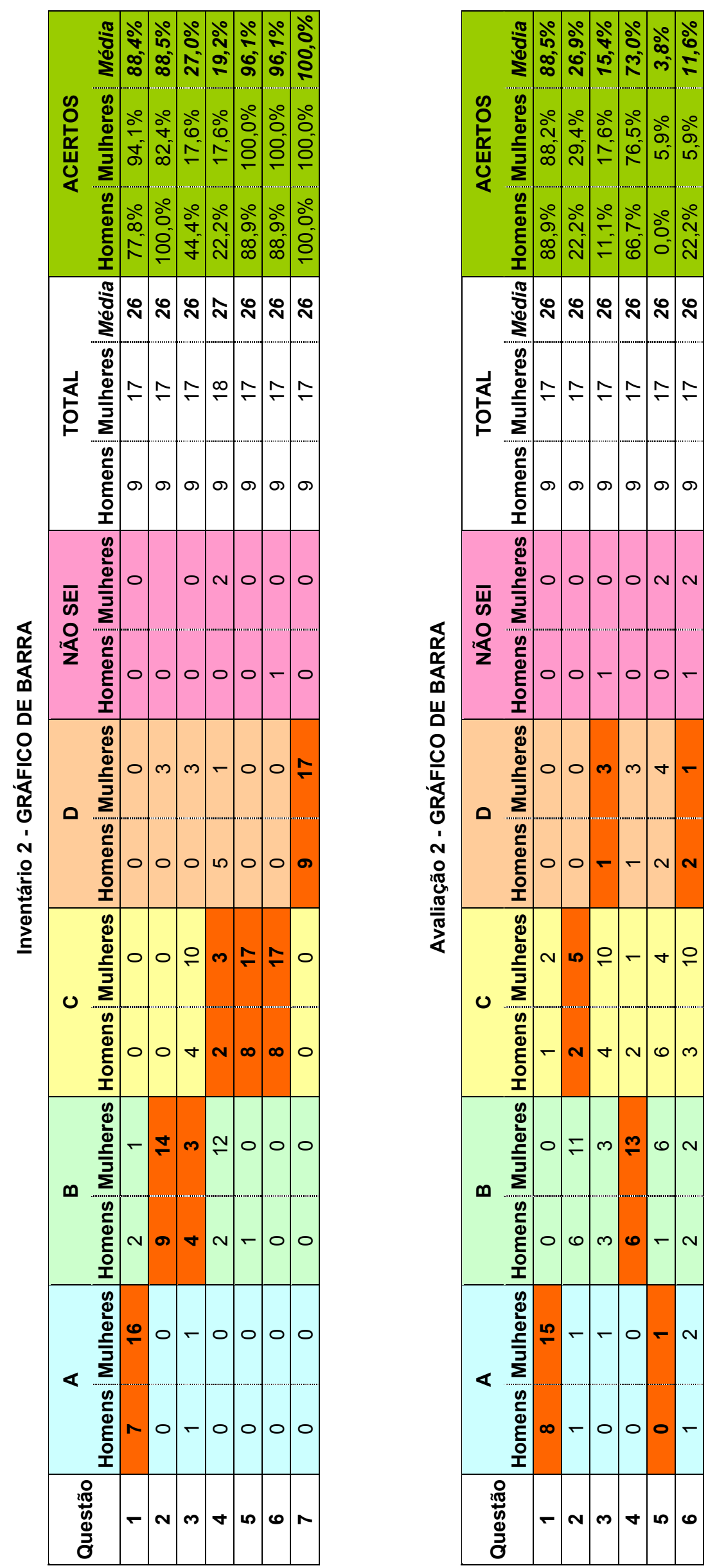

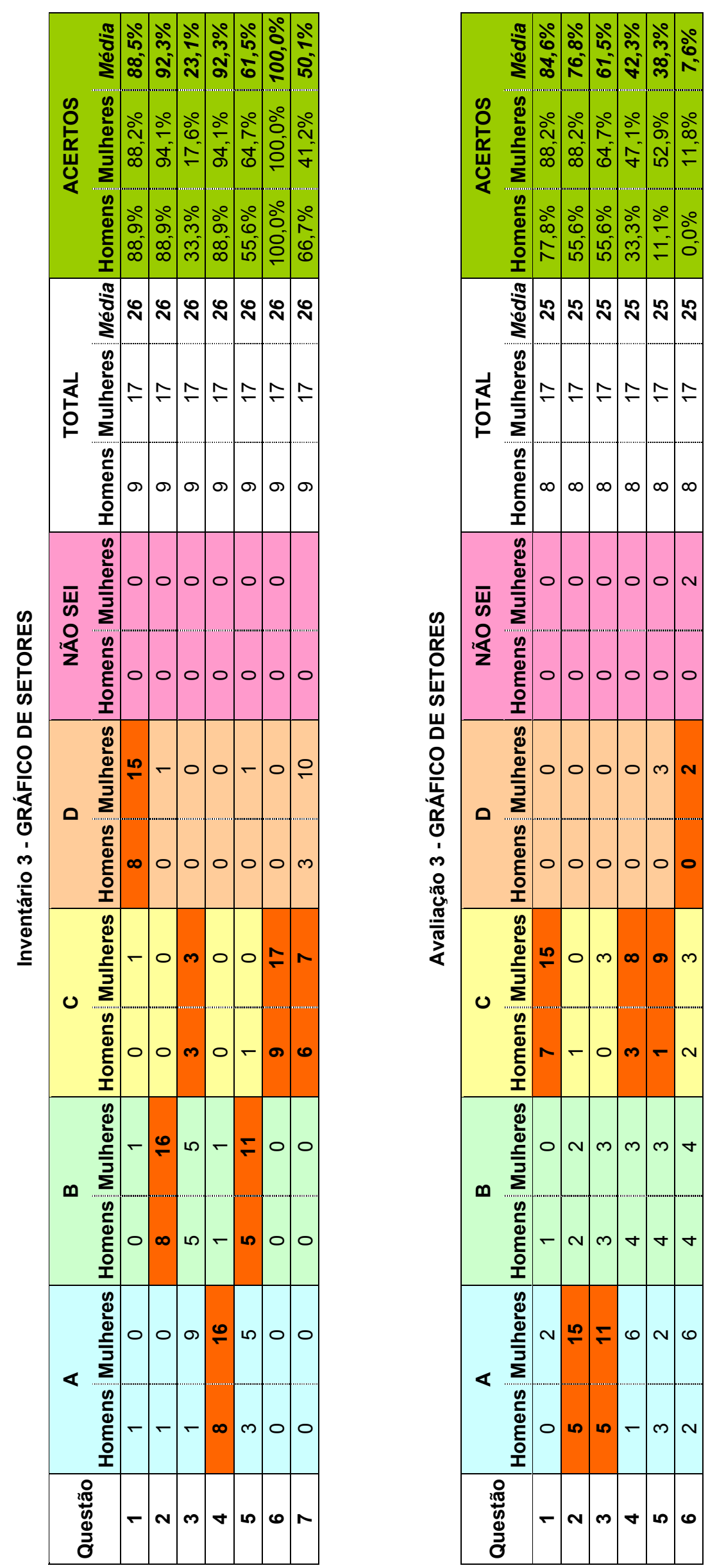


\section{APÊNDICE C - Instrumento de Coleta de Dados elaborado pelos Alunos}

\section{PREZADO COLEGA,}

Esse questionário faz parte de uma pesquisa da $8^{\mathrm{a}} \mathrm{X}$ sobre as relações que os alunos da Escola A têm com as mídias digitais (computador e celular). A sua participação é muito importante e precisamos que você seja o mais sincero possivel.

Contamos com a sua colaboração! Muito obrigado!

1. Complete os campos abaixo com suas informações:

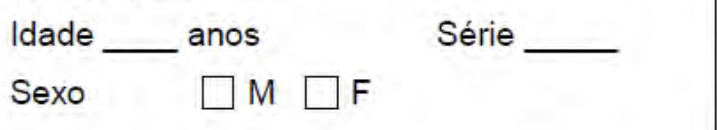

2. Indique, dentre os itens abaixo, o que você tem na sua casa:

$\square$ Computador

$\square$ Celular

3. Indique, dentre os itens abaixo, o que você utiliza:

Computador

$\square$ Celular

4. Onde você usa o computador?

$\square$ em casa

$\square$ na escola

$\square$ em lan house e cybers

$\square$ na casa de amigos/conhecidos/familiares

$\square$ não uso

5. Enumere apenas os itens que você utiliza no computador, em ordem decrescente (exemplo: 1 - o que você mais faz; 2 - a $2^{a}$ coisa que mais faz; e assim por diante).

$\square$ sites de relacionamentos (MSN e Orkut)

$\square$ jogos

$\square$ músicas (ouvir/baixar)

$\square$ vídeos (ouvir/baixar) $\square$ pesquisas

aplicativos (Word, Excel, Powerpoint, Paint, Photoshop)

$\square$ não uso

6. Quanto tempo, por dia, você costuma ficar no computador?

$\square$ não uso o computador

$\square$ menos de meia hora

$\square$ de meia hora a menos de 1 hora

$\square$ de 1 hora a menos de 2 horas

$\square$ de 2 horas a menos de 3 horas

$\square$ de 3 horas a menos de 4 horas

$\square$ mais de 4 horas

7. Enumere apenas os itens que você utiliza no celular, em ordem decrescente (exemplo: 1 - o que você mais faz; 2 - a $2^{a}$ coisa que mais faz; e assim por diante).

$\square$ não uso celular

$\square$ ligar e receber chamadas

$\square$ tirar e ver fotos

$\square$ ouvir música

$\square$ fazer e assistir vídeos

$\square$ enviar e receber torpedos sms

$\square$ acessar a internet

$\square$ assistir TV

$\square$ jogar 
APÊNDICE D - Caracterização dos Alunos da Escola A participantes do processo de investigação

\begin{tabular}{|l|l|c|c|c|c|c|c|}
\hline \multirow{2}{*}{$\mathbf{8}^{\text {a }}$ SÉRIE X DO EF } & \multicolumn{5}{|c|}{ Idade (anos) } & \multirow{2}{*}{ TOTAL } \\
\cline { 3 - 8 } & $\mathbf{1 4}$ & $\mathbf{1 5}$ & & & & 11 \\
\hline \multirow{2}{*}{ Sexo } & Meninos & 10 & 1 & & & & 15 \\
\cline { 2 - 7 } & Meninas & 14 & 1 & & & & $\mathbf{2 6}$ \\
\hline TOTAL & 24 & 2 & & & & \\
\hline
\end{tabular}

\begin{tabular}{|l|l|c|c|c|c|c|c|c|}
\hline \multirow{2}{*}{5} & \multicolumn{7}{|c|}{ Idade (anos) } & \multirow{2}{*}{ TOTAL } \\
\cline { 3 - 9 } & & $\mathbf{1 0}$ & $\mathbf{1 1}$ & $\mathbf{1 2}$ & $\mathbf{1 3}$ & $\mathbf{1 4}$ & $\mathbf{1 5}$ & \\
\hline \multirow{2}{*}{ Sexo } & Meninos & 0 & 24 & 9 & 4 & 2 & 1 & 40 \\
\cline { 2 - 9 } & Meninas & 2 & 35 & 3 & 1 & 0 & 1 & 42 \\
\hline \multirow{2}{*}{ TOTAL } & 2 & 59 & 12 & 5 & 2 & 2 & $\mathbf{8 2}$ \\
\hline
\end{tabular}

\begin{tabular}{|l|l|c|c|c|c|c|}
\hline \multirow{2}{*}{$6^{\text {a }}$ SÉRIE DO EF } & \multicolumn{5}{|c|}{ Idade (anos) } & TOTAL \\
\cline { 3 - 7 } & & $\mathbf{1 1}$ & $\mathbf{1 2}$ & $\mathbf{1 3}$ & $\mathbf{1 4}$ & \\
\hline \multirow{2}{*}{ Sexo } & Meninos & 2 & 22 & 8 & 2 & 34 \\
\cline { 2 - 7 } & Meninas & 1 & 37 & 3 & 2 & 43 \\
\hline \multirow{2}{*}{ TOTAL } & 3 & 59 & 11 & 4 & $\mathbf{7 7}$ \\
\hline
\end{tabular}

\begin{tabular}{|c|c|c|c|c|c|c|}
\hline \multirow{2}{*}{\multicolumn{2}{|c|}{ 7ª SÉRIE DO EF }} & \multicolumn{4}{|c|}{ Idade (anos) } & \multirow{3}{*}{$\begin{array}{c}\text { TOTAL } \\
40\end{array}$} \\
\hline & & 12 & 13 & 14 & 15 & \\
\hline \multirow{2}{*}{ Sexo } & Meninos & 3 & 31 & 4 & 2 & \\
\hline & Meninas & 1 & 31 & 4 & 1 & 37 \\
\hline \multicolumn{2}{|c|}{ TOTAL } & 4 & 62 & 8 & 3 & 77 \\
\hline
\end{tabular}

\begin{tabular}{|l|l|c|c|c|c|c|c|}
\hline \multirow{2}{*}{$\mathbf{8}^{\text {a }}$ SÉRIE DO EF } & \multicolumn{5}{|c|}{ Idade (anos) } & \multirow{2}{*}{ TOTAL } \\
\cline { 3 - 8 } & Meninos & $\mathbf{1 3}$ & $\mathbf{1 4}$ & $\mathbf{1 5}$ & $\mathbf{1 6}$ & $\mathbf{1 7}$ & \\
\hline \multirow{2}{*}{ Sexo } & Meninas & 1 & 19 & 8 & 3 & 1 & 35 \\
\hline \multicolumn{2}{|l|}{ TOTAL } & 5 & 11 & 5 & 1 & 1 & 19 \\
\hline
\end{tabular}

\begin{tabular}{|l|l|c|c|c|c|c|c|}
\hline \multirow{2}{*}{$1^{\circ}$ ANO DO EM } & \multicolumn{5}{|c|}{ Idade (anos) } & \multirow{2}{*}{ TOTAL } \\
\cline { 3 - 8 } & Meninos & 14 & $\mathbf{1 5}$ & $\mathbf{1 6}$ & $\mathbf{1 7}$ & $\mathbf{1 8}$ & \\
\hline \multirow{2}{*}{ Sexo } & Meninas & 3 & 27 & 7 & 4 & 1 & 40 \\
\hline \multicolumn{2}{|l|}{ TOTAL } & 4 & 63 & 10 & 3 & 0 & 52 \\
\hline
\end{tabular}

\begin{tabular}{|l|l|c|c|c|c|c|}
\hline \multirow{2}{*}{$2^{\circ}$ ANO DO EM } & \multicolumn{5}{|c|}{ Idade (anos) } & \multirow{2}{*}{ TOTAL } \\
\cline { 3 - 7 } & $\mathbf{1 5}$ & $\mathbf{1 6}$ & $\mathbf{1 7}$ & $\mathbf{1 8}$ & \\
\hline \multirow{2}{*}{ Sexo } & Meninos & 0 & 16 & 15 & 4 & 35 \\
\cline { 2 - 7 } & Meninas & 1 & 21 & 4 & 3 & 29 \\
\hline \multirow{2}{*}{ TOTAL } & 1 & 37 & 19 & 7 & $\mathbf{6 4}$ \\
\hline
\end{tabular}

\begin{tabular}{|l|l|c|c|c|c|c|}
\hline \multirow{2}{*}{3} & \multicolumn{5}{|c|}{ Idade (anos) } & \multirow{2}{*}{ TOTAL } \\
\cline { 3 - 7 } & & $\mathbf{1 6}$ & $\mathbf{1 7}$ & $\mathbf{1 8}$ & $\mathbf{1 9}$ & \\
\hline \multirow{2}{*}{ Sexo } & Meninos & 1 & 14 & 6 & 0 & 21 \\
\cline { 2 - 7 } & Meninas & 2 & 19 & 8 & 2 & 31 \\
\hline \multicolumn{2}{|l|}{ TOTAL } & 3 & 33 & 14 & 2 & $\mathbf{5 2}$ \\
\hline
\end{tabular}

\begin{tabular}{|l|l|c|c|c|c|c|c|c|c|c|c|c|}
\hline \multirow{2}{*}{ ESCOLA A } & \multicolumn{10}{|c|}{ Idade (anos) } & \multirow{2}{*}{ TOTAL } \\
\cline { 3 - 15 } & $\mathbf{1 0}$ & $\mathbf{1 1}$ & $\mathbf{1 2}$ & $\mathbf{1 3}$ & $\mathbf{1 4}$ & $\mathbf{1 5}$ & $\mathbf{1 6}$ & $\mathbf{1 7}$ & $\mathbf{1 8}$ & $\mathbf{1 9}$ & \\
\hline \multirow{2}{*}{ Sexo } & Meninos & 0 & 26 & 34 & 47 & 38 & 39 & 27 & 34 & 11 & 0 & 256 \\
\cline { 2 - 15 } & Meninas & 2 & 36 & 41 & 36 & 34 & 45 & 34 & 27 & 11 & 2 & 268 \\
\hline TOTAL & 2 & 62 & 75 & 83 & 72 & 84 & 61 & 61 & 22 & 2 & $\mathbf{5 2 4}$ \\
\hline
\end{tabular}




\section{APÊNDICE E - Conhecendo o SuperLogo 3.0}

\section{CONHECENDO O SUPERLOGO 3.0}

A tartaruga è um cursor gráfico que aparece no centro da tela gráfica. Para fazer desenhos basta movimentá-la na tela de modo que ela deixe traços pelo seu caminho. Há quatro comandos básicos que movimentam a tartaruga:

$\rightarrow$ PARAFRENTE $\left(\mathrm{PF}<\mathrm{n}^{\circ}\right.$ passo $\left.>\right)-\mathrm{PF} 20$

$\rightarrow$ PARATRÁS $\left(\mathrm{PT}<\mathrm{n}^{\circ}\right.$ passos $>$ ) $-\mathrm{PT} 60$

$\rightarrow$ PARADIREITA (PD $<n^{\circ}$ graus) - PD 45

$\rightarrow$ PARAESQUERDA (PE $<n^{\circ}$ graus $\left.>\right)-P E 90$

Outros comandos básicos são:

$\rightarrow$ USENADA (UN) $=$ a tartaruga se movimenta sem deixar traços.

$\rightarrow$ USEBORRACHA (UB) = apaga traços na tela

$\rightarrow$ USELÁPIS (UL) = retorna a movimentar-se desenhando os traços.

$\rightarrow$ DESAPAREÇATAT $($ DT) $=$ a tartaruga fica invisivel.

$\rightarrow$ APAREÇATAT $($ AT $)=$ a tartaruga volta a ser visível.

$\rightarrow$ PARACENTRO $(\mathrm{PC})=$ a tartaruga retorna ao centro $[0,0]$ da tela.

$\rightarrow$ TAT $=$ limpa a tela, recoloca a tartaruga no centro da tela.

Vamos treinar: Construa um quadrado de lado 80, um retângulo de lados 120 e 60 e um triângulo eqüilátero de lados 80 .

O comando ROTULE escreve na tela da tartaruga e precisa de um parâmetro, onde o conteúdo deste seria impresso.

$\rightarrow$ ROTULE [MATEMÁTICA] = aparecerá a palavra MATEMÁTICA no local onde a tartaruga estiver localizada.

Vamos treinar: Escreva a palavra MíDIA dentro do quadrado construido anteriormente.

Também é possível trabalhar com cores nos desenhos e linhas construídos no SuperLogo. Abaixo alguns comandos para se trocar as cores:

$\rightarrow$ MUDECF (MUDECF $<n^{\circ}$ da cor $>$ ) $=$ muda cor do fundo da janela gráfica. $\rightarrow$ MUDECL (MUDECL $<n^{\circ}$ da cor $>$ ) = muda cor do lápis (traço).

$\rightarrow$ MUDECP (MUDECP $<n^{\circ}$ da cor $>$ ) $=$ muda cor do pincel (para preenchimento).

$\rightarrow$ PINTE $=$ preenche 0 espaço onde está a tartaruga.

\begin{tabular}{|l|l|l|l|}
\hline \multicolumn{4}{|c|}{ Segue a tabela de cores: } \\
\hline $\mathbf{N}^{\circ}$ & $\begin{array}{l}\text { Cor } \\
\text { correspondente }\end{array}$ & $\mathbf{N}^{\circ}$ & $\begin{array}{l}\text { Cor } \\
\text { correspondente }\end{array}$ \\
\hline 0 & Preto & 8 & Cinza Escuro \\
\hline 1 & Azul & 9 & Verde Água \\
\hline 2 & Verde & 10 & Verde Claro \\
\hline 3 & Ciano & 11 & Ciano Claro \\
\hline 4 & Vermelho & 12 & Verde Escuro \\
\hline 5 & Roxo & 13 & Rosa \\
\hline 6 & Marron & 14 & Amarelo \\
\hline 7 & Cinza Claro & 15 & Branco \\
\hline
\end{tabular}

ARCO <ângulo > <raio > = desenha um arco com ângulo e raio digitados.

Exemplos:

- arco 360100 (forma uma circunferência de raio $100)$;

- arco 60150 (forma um arco de circunferência de $60^{\circ}$ com raio 150 )

CIRCUNFERÊNCIA <raio> = desenha uma circunferência com o raio digitado.

Exemplos: circunferência 50; circunferência 100

Vamos treinar: Construa um circulo de raio 100 . Depois, como se estivéssemos cortando um pedaço de pizza, construa um setor de raio $60 \mathrm{e}$ pinte de amarelo.

O comando REPITA é usado quando se quer efetuar uma mesma ação, ou sequência de ações, em um determinado número de vezes. $\dot{E}$ necessário dois parâmetros, um número e uma lista:

$\rightarrow$ REPITA < numero > lista $>$

Onde na lista é posto os comandos a serem repetidos. Vejamos como ficaria o exemplo do quadrado com o comando REPITA: REPITA 4 [PF 80 PE 90] 
APÊNDICE F - Apresentação Final do Projeto publicada no blog da Escola A

\section{A RELAÇÃO DOS ALUNOS DA ESCOLAA COM AS MIIDIAS DIGITAIS: COMPUTADOR E CELULAR}

Vivenciando uma Investigação Exploratória de Dados com os Alunos da $8^{a} X$

Projeto Desenvolvido junto às Oficinas de Experiências Matemáticas e Informática Educacional, sob responsabilidade e orientação das

(1)

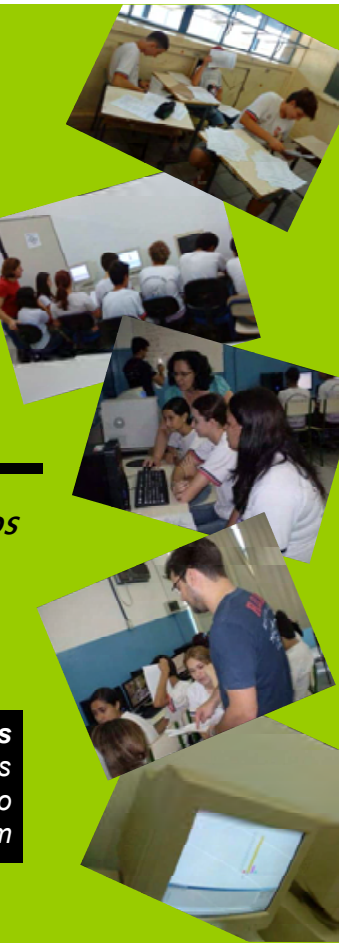

\section{Desenvolvimento do Projeto}

- O tema surgiu da realidade e do interesse dos alunos da $8^{a} X$

- O questionário foi elaborado pelos alunos com o auxílio dos professores

- Os alunos aplicaram os questionários em todas as salas da escola, num total de 524 entrevistados

- Os alunos organizaram os dados em tabelas

- Alguns dos dados foram representados em gráficos construídos por meio do Software SuperLogo 3.0

- Os alunos fizeram as análises dos dados e tiraram suas conclusões conforme segue 


\section{Análise dos dados da $8^{\mathrm{a}} \mathrm{X}$}

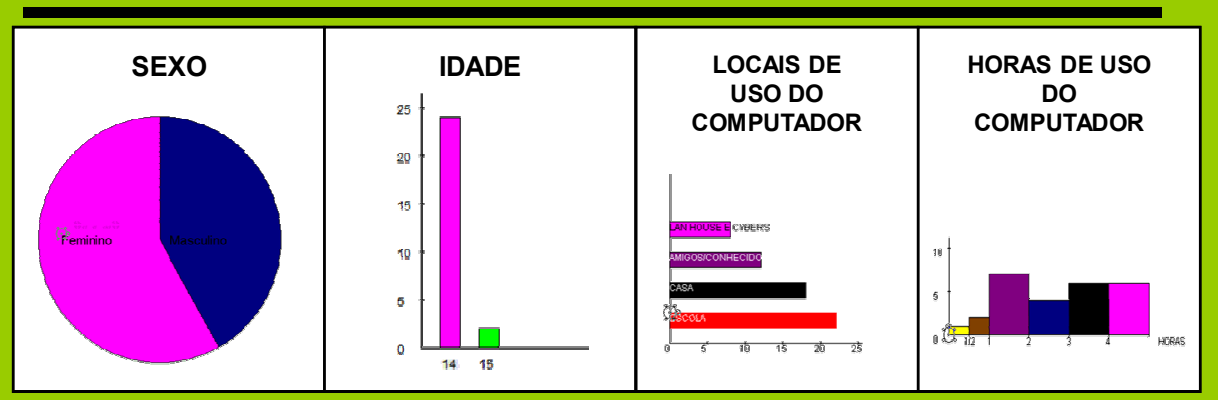

"Tem um pouco mais de meninas do que meninos".

"Os alunos da $8^{a} X$ tem entre 14 e 15 anos, sendo que tem muito mais gente de 14 do que de 15 ".

"Os alunos usam bastante computador na escola".

"A maioria dos alunos fica de 1 a 2 horas no computador por dia".

\section{Análise dos dados da $8^{\mathrm{a}} \mathrm{X}$}

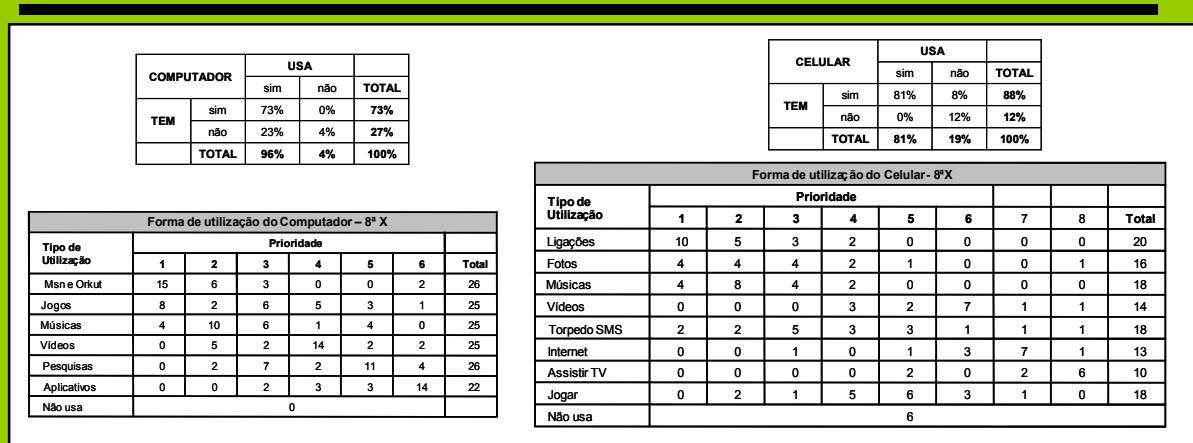

"73\% tem computador".

"Quase todo mundo tem celular".

"O que mais faz no computador é usar MSN e Orkut".

"O celular é mais usado pra fazer ligações, ouvir música e enviar torpedo". 


\section{Análise Comparativa entre os dados da $8^{\mathrm{a}} \mathrm{X}$ e das outras $8^{\mathrm{a}} \mathrm{s}$ séries}

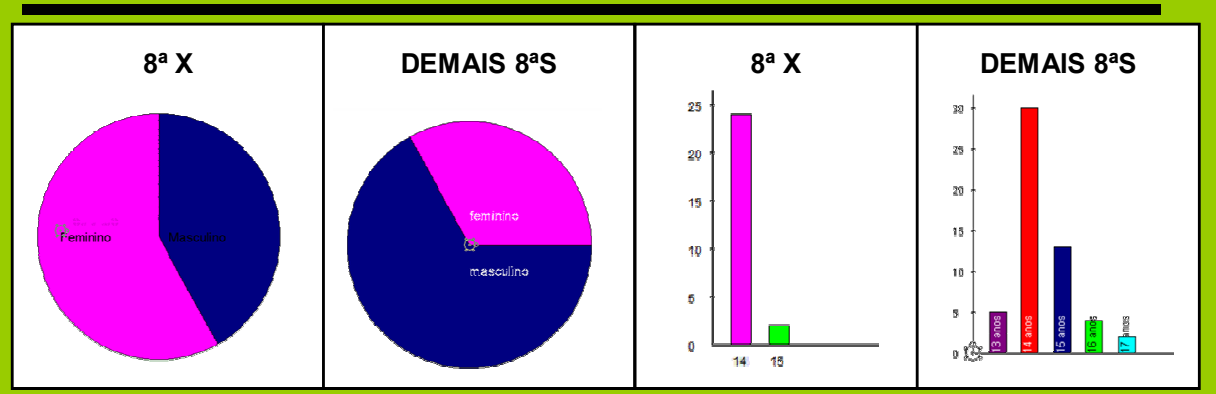

"Nossa sala tem mais meninas e nas outras oitavas tem mais meninos".

"Aqui só tem aluno de 14 e 15 anos e nas outras oitavas tem gente com 13, 16 e 17".

\section{Análise Comparativa entre os dados da $8^{\mathrm{a}} \mathrm{X}$ e das outras $8^{\mathrm{a}} \mathrm{s}$ séries}

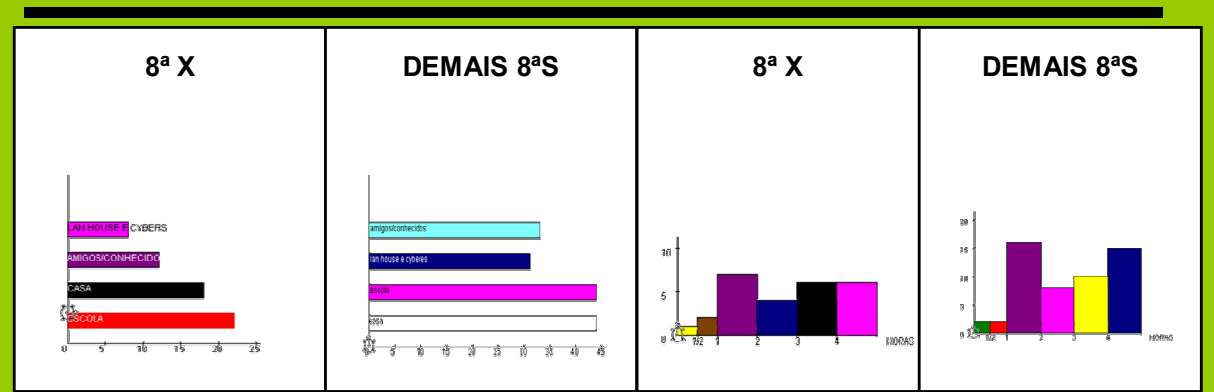

"Na $8^{a} X$ o lugar onde mais usa computador é na escola e em segundo é em casa. Nas outras $8^{a}$ s esses dois lugares empatam em primeiro".

"Nas outras 8 a s também o que mais tem é de 1 a 2 horas no computador" 
Análise Comparativa entre os dados da $8^{\mathrm{a}} \mathrm{X}$ e das outras $8^{\mathrm{a}} \mathrm{s}$ séries

\begin{tabular}{|c|c|c|c|c|c|c|c|c|c|}
\hline \multicolumn{5}{|c|}{$8^{a} X$} & \multicolumn{5}{|c|}{ DEMAIS $8^{\mathrm{a} S}$} \\
\hline \multirow{2}{*}{\multicolumn{2}{|c|}{ COMPUTADOR }} & \multicolumn{2}{|c|}{ USA } & & \multirow{2}{*}{\multicolumn{2}{|c|}{ COMPUTADOR }} & \multicolumn{2}{|c|}{ USA } & \multirow{3}{*}{$\begin{array}{l}\text { TOTAL } \\
85 \% \\
\end{array}$} \\
\hline & & sim & não & TOTAL & & & $\operatorname{sim}$ & não & \\
\hline \multirow[t]{2}{*}{ TEM } & \multirow{2}{*}{\begin{tabular}{|c|} 
năo \\
TOTAL
\end{tabular}} & $23 \%$ & \multirow{2}{*}{$4 \%$} & \multirow{3}{*}{$\begin{array}{l}27 \% \\
100 \% \\
\end{array}$} & \multirow{3}{*}{ TEM } & $\operatorname{sim}$ & $85 \%$ & $0 \%$ & \\
\hline & & $96 \%$ & & & & não & $6 \%$ & $9 \%$ & $15 \%$ \\
\hline \multirow{3}{*}{\multicolumn{2}{|c|}{ CELULAR }} & & & & & TOTAL & $91 \%$ & $9 \%$ & $100 \%$ \\
\hline & & \multicolumn{2}{|c|}{ USA } & & \multirow{2}{*}{\multicolumn{2}{|c|}{ CELULAR }} & \multicolumn{2}{|c|}{ USA } & \\
\hline & & sim & กão & TOTAL & & & $\sin$ & não & TOTAL \\
\hline \multirow[t]{3}{*}{ TEM } & sim & $81 \%$ & $8 \%$ & $88 \%$ & \multirow{3}{*}{ TEM } & $\operatorname{sim}$ & $85 \%$ & $11 \%$ & $96 \%$ \\
\hline & não & $0 \%$ & $12 \%$ & $12 \%$ & & não & $0 \%$ & $4 \%$ & $4 \%$ \\
\hline & TOTAL & $81 \%$ & $19 \%$ & $100 \%$ & & TOTAL & $85 \%$ & $15 \%$ & $100 \%$ \\
\hline
\end{tabular}

"Nas outras $8{ }^{a}$ s $85 \%$ tem computador".

"Quase todo mundo tem celular em todas as oitavas".

Fundamentos para compreender a Variabilidade entre os Grupos: SEXO

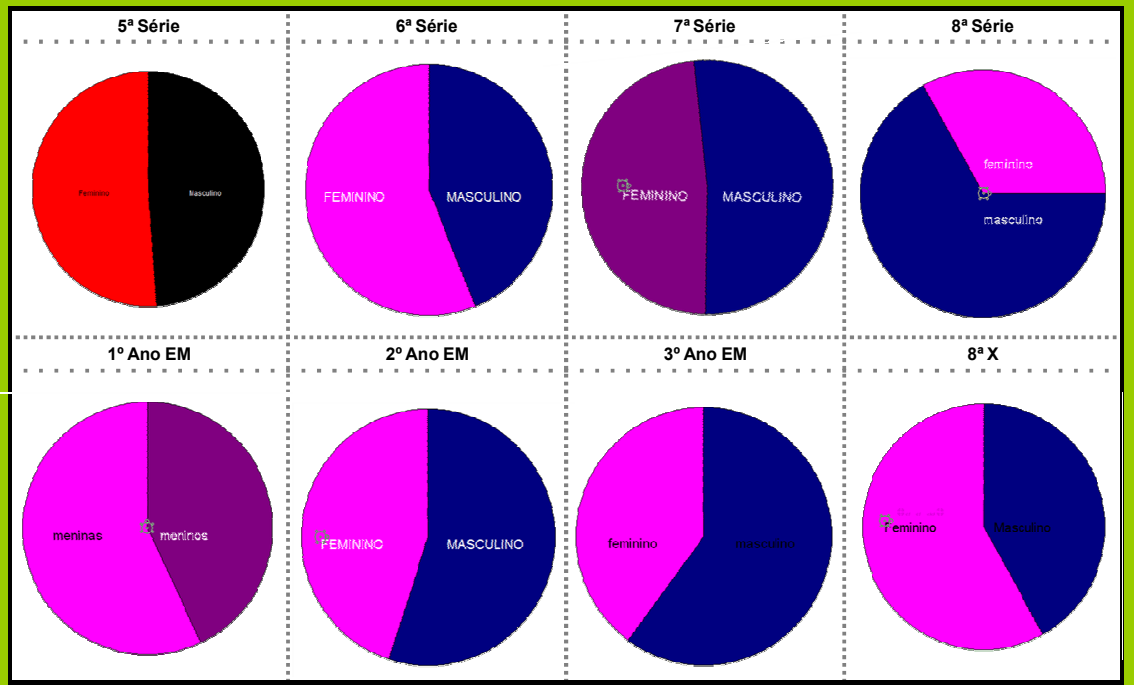


Fundamentos para compreender a

Variabilidade entre os Grupos: IDADE

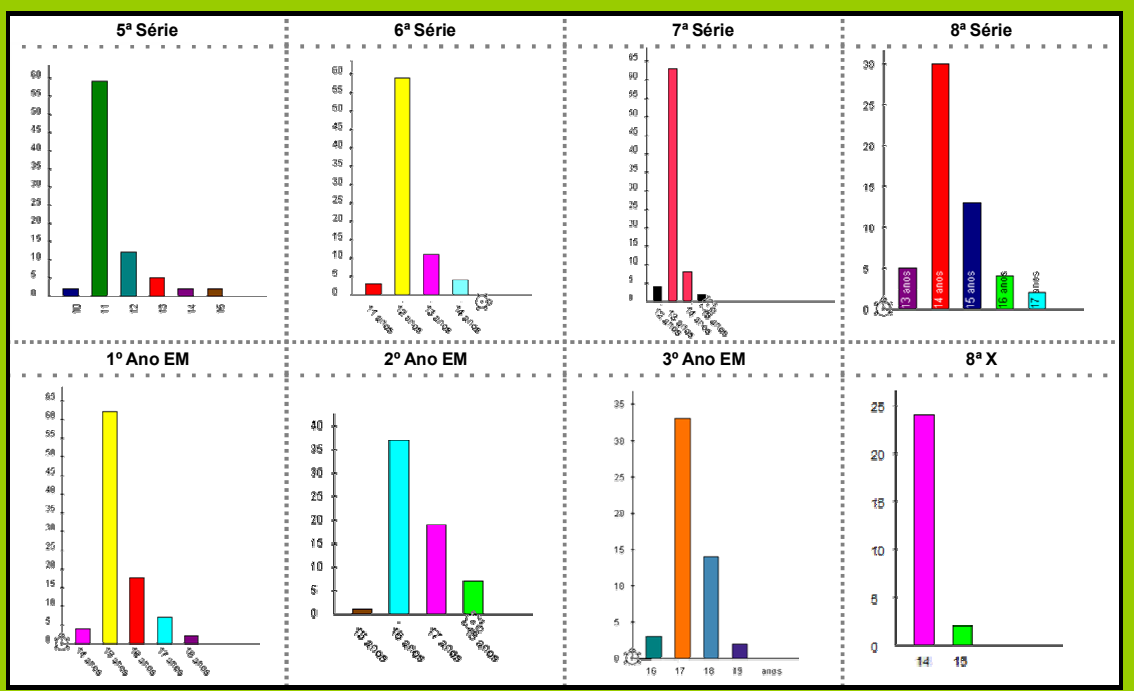

Fundamentos para compreender a

Variabilidade entre os Grupos:

LOCAIS DE USO DO COMPUTADOR

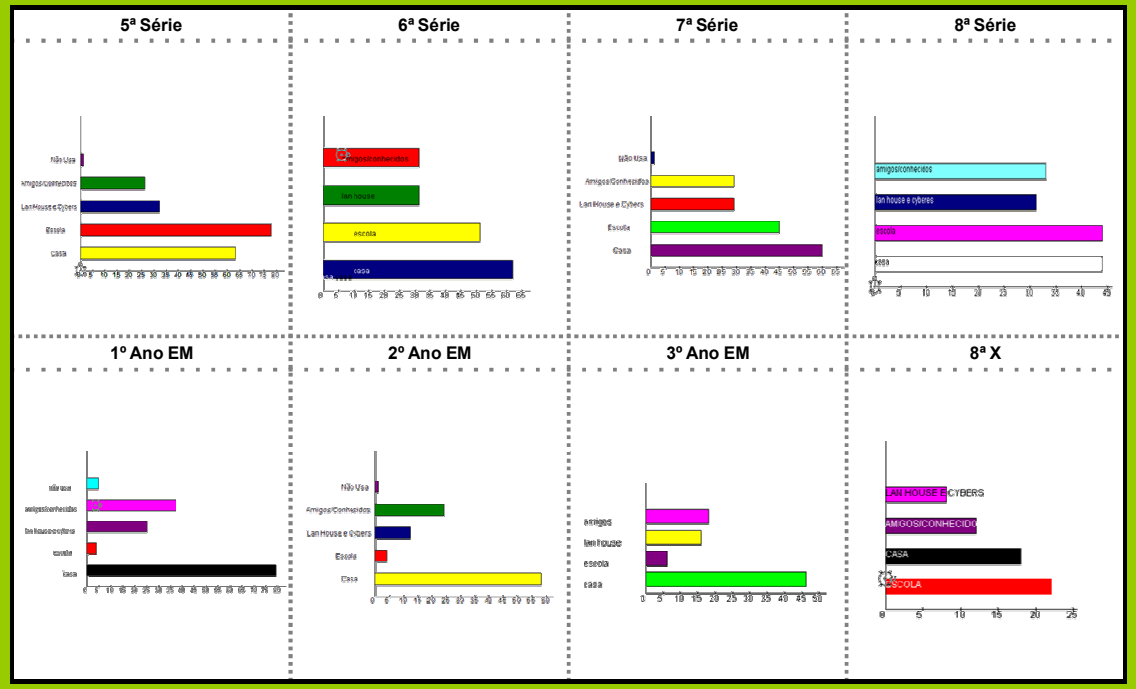


Fundamentos para compreender a

Variabilidade entre os Grupos:

HORAS DE USO DO COMPUTADOR

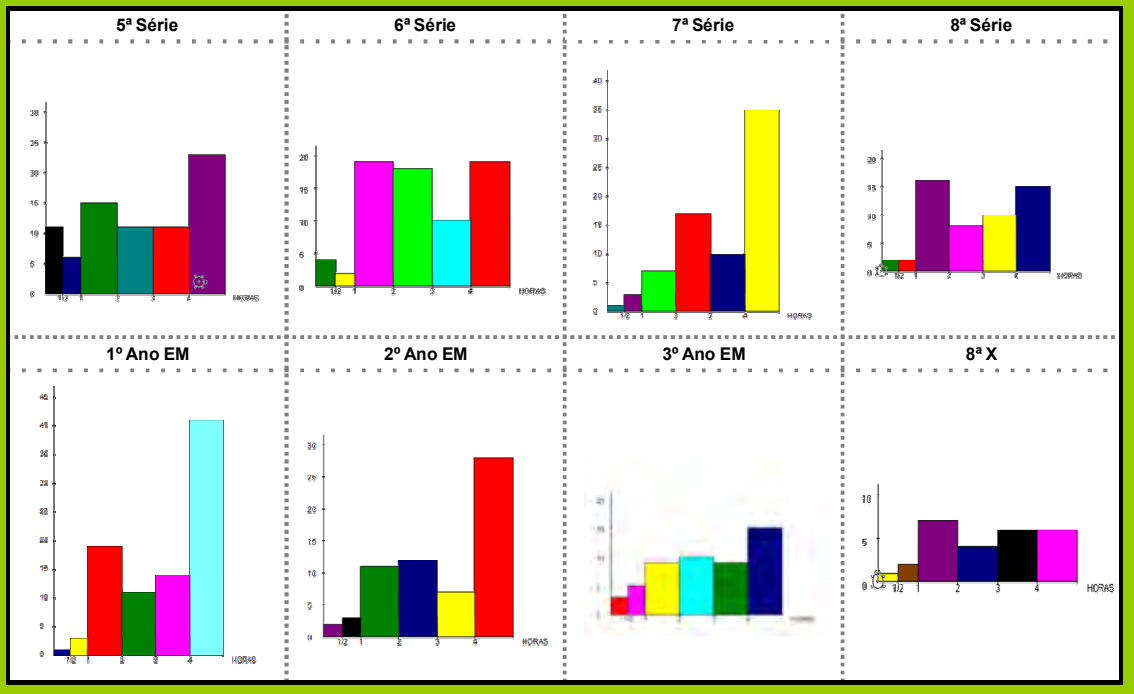

A $8^{a} X$ pode ser considerada uma boa amostra das características de todos os alunos da Escola $A$ ?

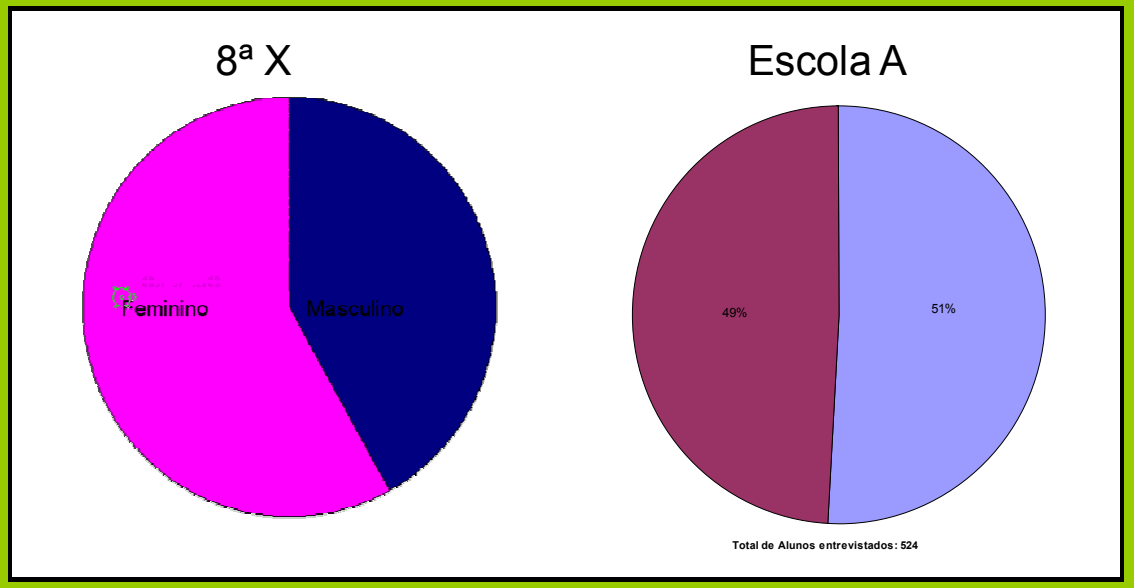

"Na $8^{a} X$ tem mais meninas e na escola inteira tem mais meninos". 
A $8^{\text {a }} X$ pode ser considerada uma boa amostra das características de todos os alunos da Escola A?

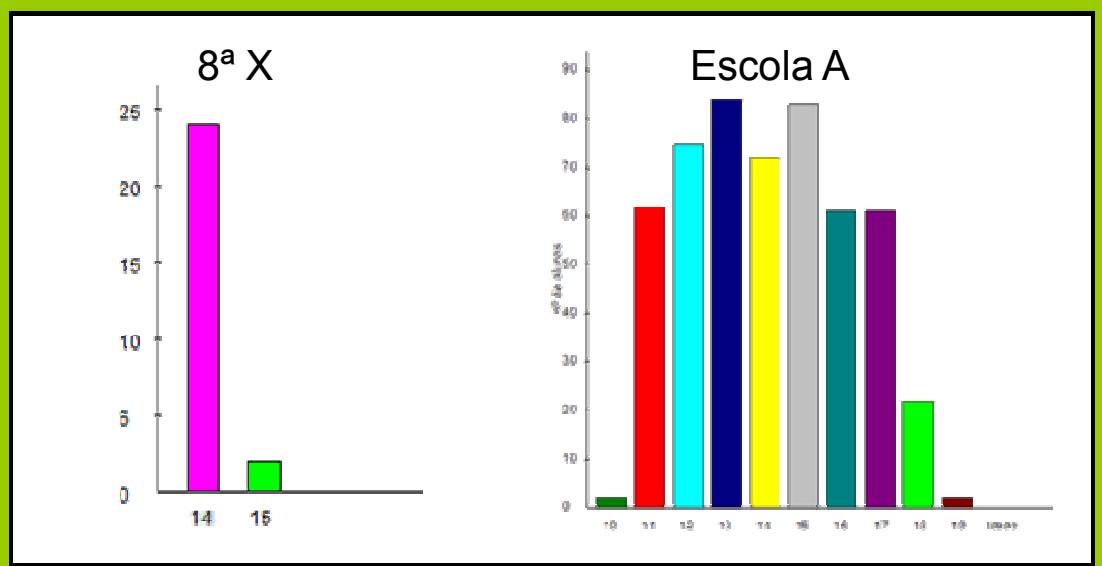

"A $8^{a} X$ não pode ser considerada como representação de toda a escola, porque na $8^{a} X$ os alunos têm entre 14 e 15 anos já os alunos de toda a escola as idades variam muito".

A $8^{\text {a }} X$ pode ser considerada uma boa amostra das características de todos os alunos da Escola $A$ ?

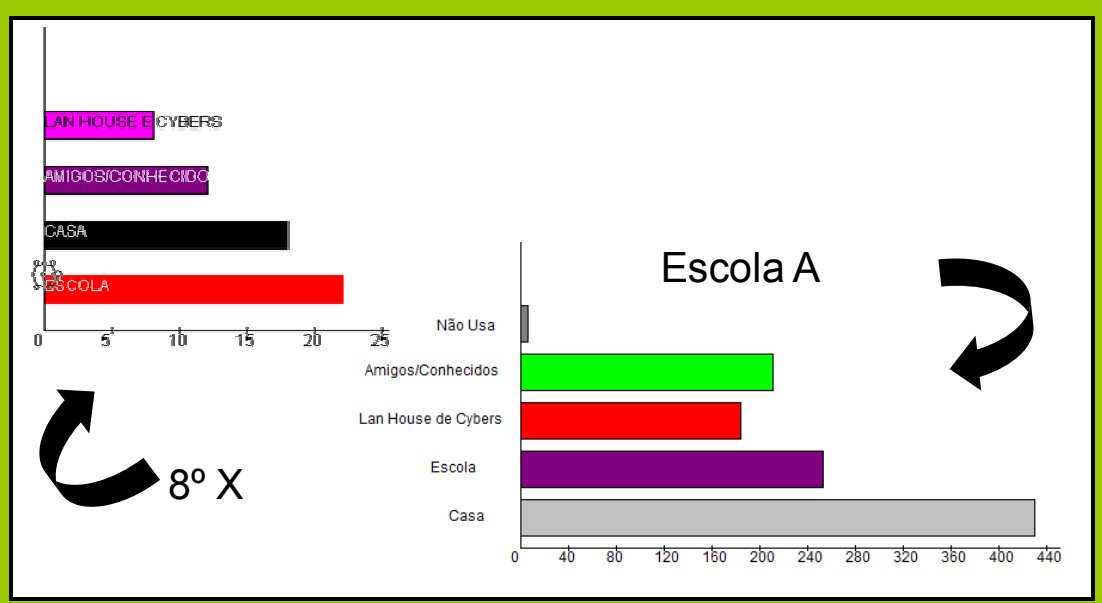

"Na $8^{a} X$ os alunos usam mais computador na escola e na escola toda os alunos usam mais computador em casa". 
A $8^{\text {a }} \mathrm{X}$ pode ser considerada uma boa amostra das características de todos os alunos da Escola A?

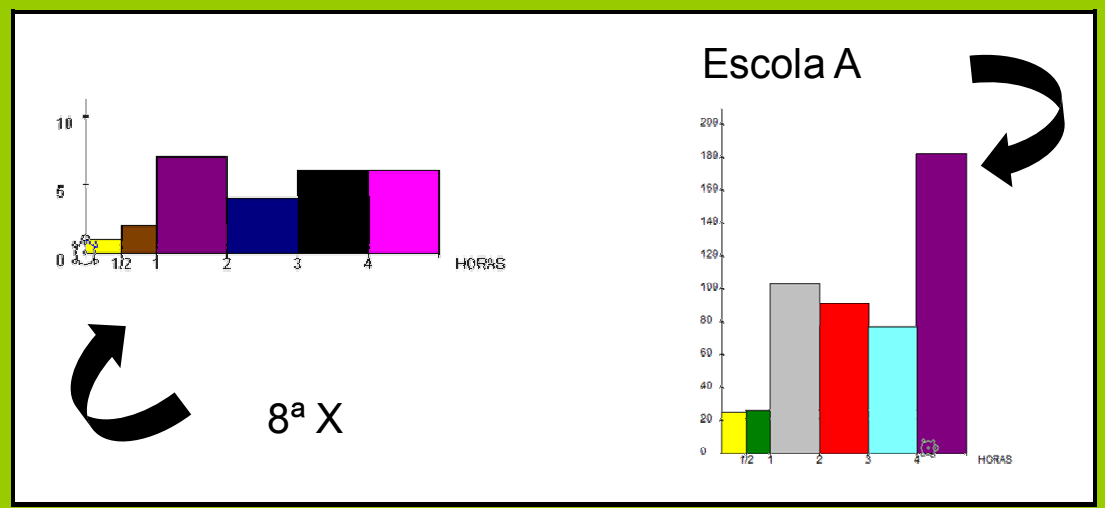

"As características da $8^{a} X$ são totalmente diferentes da escola toda, por exemplo: o total de alunos que ficam mais de 4 horas no computador na $8^{a} X$ é menor do que o total que fica de 1 a 2 horas e na escola inteira $o$ total de pessoas que fica mais de 4 horas é muito maior do que de 1 a 2 horas".

\section{A $8^{a} X$ pode ser considerada uma boa amostra das características de todos os alunos da Escola A?}

\begin{tabular}{|c|c|c|c|c|c|c|c|c|c|}
\hline \multicolumn{5}{|c|}{$8^{a} X$} & \multicolumn{5}{|c|}{ ESCOLA A } \\
\hline \multirow{2}{*}{\multicolumn{2}{|c|}{ COMPUTADOR }} & \multirow{2}{*}{\multicolumn{2}{|c|}{ USA }} & & \multirow{2}{*}{\multicolumn{2}{|c|}{ COMPUTADOR }} & \multicolumn{2}{|c|}{ USA } & \multirow{3}{*}{$\begin{array}{c}\text { TOTAL } \\
\mathbf{8 4} \%\end{array}$} \\
\hline & & & & \multirow{3}{*}{$\begin{array}{c}\text { TOTAL } \\
73 \% \\
\end{array}$} & & & $\operatorname{sim}$ & não & \\
\hline \multirow{3}{*}{ TEM } & & sim & năo & & \multirow{2}{*}{ TEM } & $\operatorname{sim}$ & $81 \%$ & $3 \%$ & \\
\hline & $\operatorname{sim}$ & $73 \%$ & $0 \%$ & & & não & $9 \%$ & $7 \%$ & $16 \%$ \\
\hline & $\frac{\text { não }}{\text { TOTAL }}$ & $\frac{23 \%}{96 \%}$ & $4 \%$ & $\frac{27 \%}{100 \%}$ & & TOTAL & $90 \%$ & $10 \%$ & $100 \%$ \\
\hline \multirow{2}{*}{\multicolumn{2}{|c|}{ CELULAR }} & \multicolumn{2}{|c|}{ USA } & & \multirow{2}{*}{\multicolumn{2}{|c|}{ CELULAR }} & \multicolumn{2}{|c|}{ USA } & \\
\hline & & sim & não & TOTAL & & & sim & não & TOTAL \\
\hline \multirow{3}{*}{ TEM } & $\operatorname{sim}$ & $81 \%$ & $8 \%$ & $88 \%$ & \multirow{3}{*}{ TEM } & $\operatorname{sim}$ & $86 \%$ & $6 \%$ & $92 \%$ \\
\hline & não & $0 \%$ & $12 \%$ & $12 \%$ & & não & $2 \%$ & $6 \%$ & $8 \%$ \\
\hline & TOTAL & $81 \%$ & $19 \%$ & $100 \%$ & & TOTAL & $88 \%$ & $12 \%$ & $100 \%$ \\
\hline
\end{tabular}

"As porcentagens de quem tem computador são quase as mesmas na $8^{a}$ B e na escola".

"88\% dos alunos da $8^{a} \times$ tem celular e $92 \%$ dos alunos da escola tem celular". 
A $8^{\text {a }} X$ pode ser considerada uma boa amostra das características de todos os alunos da Escola $\mathrm{A}$ ?

\begin{tabular}{|c|c|c|c|c|c|c|c|}
\hline \multicolumn{8}{|c|}{ Forma de utilização do Computador -Escola A) } \\
\hline \multirow{2}{*}{$\begin{array}{l}\text { Tipo de } \\
\text { Utilização }\end{array}$} & \multicolumn{6}{|c|}{ Prioridade } & \multirow[b]{2}{*}{ Total } \\
\hline & 1 & 2 & 3 & 4 & 5 & 6 & \\
\hline Msn e Orkut & 317 & 77 & 31 & 26 & 8 & 19 & 478 \\
\hline Jogos & 110 & 101 & 55 & 101 & 37 & 35 & 439 \\
\hline Músicas & 44 & 231 & 133 & 48 & 19 & 5 & 480 \\
\hline Videos & 9 & 49 & 159 & 134 & 41 & 24 & 416 \\
\hline Pesquisas & 15 & 22 & 61 & 79 & 202 & 68 & 447 \\
\hline Aplicativos & 5 & 13 & 22 & 55 & 101 & 208 & 404 \\
\hline Não usa & & & & & & & \\
\hline
\end{tabular}

"Todos usam o computador em $1^{\circ}$ lugar para MSN e Orkut e em segundo lugar para música. Só e diferente a partir do terceiro, que na nossa sala é pesquisa e na escola é vídeo".

\section{A $8^{a} X$ pode ser considerada uma boa amostra das características de todos os alunos da Escola $A$ ?}

\begin{tabular}{|l|c|c|c|c|c|c|c|c|c|}
\hline \multicolumn{10}{|c|}{ Forma de utilização do Celular -Escola A } \\
\hline \multirow{2}{*}{$\begin{array}{l}\text { Tipo de } \\
\text { Utilização }\end{array}$} & $\mathbf{1}$ & $\mathbf{2}$ & $\mathbf{3}$ & $\mathbf{4}$ & $\mathbf{5}$ & $\mathbf{6}$ & $\mathbf{7}$ & $\mathbf{8}$ & Total \\
\cline { 2 - 12 } \\
\hline Ligações & 244 & 60 & 25 & 25 & 14 & 15 & 11 & 16 & 410 \\
\hline Fotos & 49 & 131 & 93 & 45 & 31 & 19 & 13 & 5 & 386 \\
\hline Músicas & 82 & 121 & 130 & 33 & 26 & 10 & 3 & 0 & 405 \\
\hline Videos & 1 & 15 & 38 & 91 & 62 & 49 & 27 & 15 & 298 \\
\hline Torpedo SMS & 18 & 55 & 65 & 72 & 76 & 35 & 28 & 14 & 363 \\
\hline Internet & 9 & 12 & 13 & 21 & 33 & 72 & 41 & 45 & 246 \\
\hline Assistir TV & 12 & 17 & 20 & 20 & 26 & 39 & 72 & 47 & 253 \\
\hline Jogar & 33 & 33 & 45 & 54 & 59 & 42 & 41 & 55 & 362 \\
\hline Não usa & \multicolumn{10}{|c|}{49} & & & & \\
\hline
\end{tabular}

"Na $8^{a} X$ e na escola o que mais os alunos fazem no celular é ligar. Mas em segundo e no terceiro lugar é diferente: na $8^{a} X$ é música e torpedo e na escola foto e música". 


\section{CONCUSÕES}

- Os alunos da Escola A fazem muitas coisas no computador e no celular, sendo que esta é uma mídia muito presente nas suas vidas

- A $8^{a} X$ não pode ser considerada uma boa amostra para a escola porque apresenta características diferentes

- Considerando a variabilidade existente entre as séries, para termos uma amostra representativa precisamos escolher de maneira aleatória um número de alunos de cada série proporcional ao total

- A construção dos gráficos no SuperLogo 3.0 deu muito trabalho. Mas com isso, os alunos puderam trabalhar conceitos matemáticos (razão, proporção, porcentagem, ângulos) e estabelecer a tomar consciência da relação eixo-barra e/ou eixo-coluna presente nos gráficos. 
ANEXOS 


\section{ANEXO 1 - Questões da Prova de Matemática da $8^{\text {a }}$ série do EF do SARESP de 2005}

22. Foi perguntado a um total de 100 pessoas em uma cidade se freqüentavam cinema $e$ se freqüentavam teatro. A tabela abaixo resume o resultado desta pesquisa.

\begin{tabular}{|c|c|c|c|}
\hline & \multicolumn{2}{|c|}{ Cinema } \\
\hline & & $\operatorname{sim}$ & não \\
\hline \multirow{2}{*}{ Teatro } & $\operatorname{sim}$ & 52 & 8 \\
\hline & não & 36 & 4 \\
\hline
\end{tabular}

Se os dados dessa pesquisa forem transportados para o gráfico abaixo, a coluna pintada de laranja deve representar o número de pessoas que:

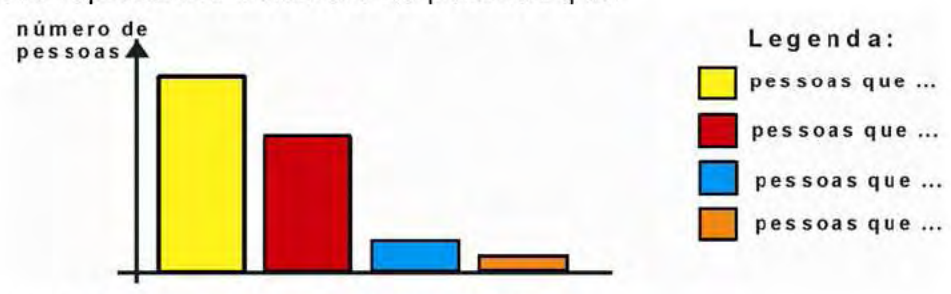

(A) freqüentam teatro e não freqüentam cinema.

(B) freqüentam cinema e não freqüentam teatro.

(C) freqüentam cinema e teatro.

(D) não freqüentam nem cinema nem teatro.

23. O aquecimento global traz graves conseqüências ecológicas. $O$ aumento da temperatura dos oceanos, por exemplo, coloca em risco a flora e fauna marinha. $O$ gráfico abaixo mostra como vem aumentando a temperatura dos oceanos desde 1860 e a projeção para os próximos anos. Considerando que a temperatura crítica para a sobrevivência dos corais é de $29^{\circ} \mathrm{C}$ podemos afirmar que, segundo essa projeção, essa temperatura será atingida:

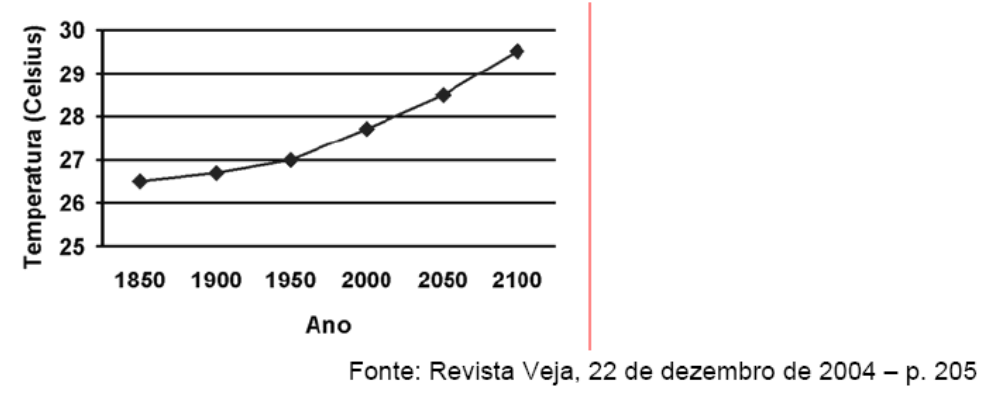
(A) entre os anos de 1950 e 2000
(B) entre os anos de 2000 e 2050
(C) entre os anos de 2050 e 2100
(D) após o ano de 2100 
24. Após medir a altura de cada um dos 27 alunos de uma turma, o professor resumiu os resultados obtidos em 5 classes, cujas freqüências estão na tabela abaixo. É correto afirmar que

\begin{tabular}{|c|c|}
\hline Altura (em metros) & Freqüência \\
\hline 1,52 a 1,55 & 7 \\
\hline 1,56 a 1,59 & 9 \\
\hline 1,60 a 1,63 & 5 \\
\hline 1,64 a 1,67 & 4 \\
\hline 1,68 a 1,72 & 2 \\
\hline
\end{tabular}

(A) 7 alunos têm altura entre $1,60 \mathrm{~m}$ e $1,63 \mathrm{~m}$.

(B) 16 alunos têm altura menor que $1,60 \mathrm{~m}$.

(C) 4 alunos têm altura entre $1,60 \mathrm{~m}$ e $1,63 \mathrm{~m}$.

(D) 5 alunos têm altura entre $1,68 \mathrm{~m}$ e $1,72 \mathrm{~m}$.

25. Os números de pontos feitos em 11 jogos por um time de basquete foram: 74,82 , $85,87,90,93,94,94,100,100,100$. A mediana dos resultados desse time, nesses 11 jogos, é de:
(A) 91 pontos
(B) 93 pontos
(C) 94 pontos
(D) 100 pontos

26. Num saco, há 5 bolas pretas e 2 brancas, todas iguais. A probabilidade de uma pessoa tirar uma bola branca do saco, de olhos fechados, é de:
(A) $\frac{1}{2}$
(B) $\frac{1}{7}$
(C) $\frac{2}{5}$
(D) $\frac{2}{7}$ 